\title{
HYDROLOGIC DATA FOR 1994-96 FOR THE HURON PROJECT OF THE HIGH PLAINS GROUND-WATER DEMONSTRATION PROGRAM
}

By Janet M. Carter

U.S. GEOLOGICAL SURVEY

Open-File Report 96-555

Prepared in cooperation with

SOUTH DAKOTA STATE UNIVERSITY, the BUREAU OF RECLAMATION, the SOUTH DAKOTA DEPARTMENT OF ENVIRONMENT AND NATURAL RESOURCES, and the CITY OF HURON

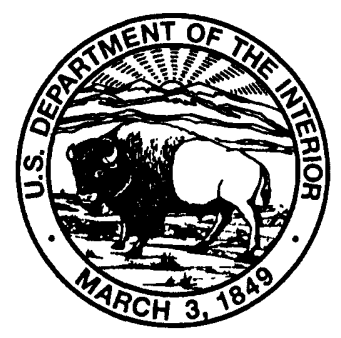




\title{
U.S. DEPARTMENT OF THE INTERIOR \\ BRUCE BABBITT, Secretary
}

\author{
U.S. GEOLOGICAL SURVEY
}

Gordon P. Eaton, Director

For additional information write to:

Copies of this report can be purchased from:

District Chief

U.S. Geological Survey

1608 Mt. View Rd.

Rapid City, SD 57702

U.S. Geological Survey

Branch of Information Services

Box 25286

Denver, CO 80225 


\section{CONTENTS}

Abstract

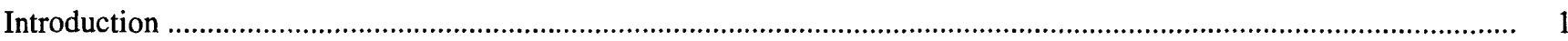

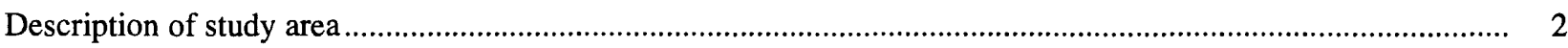

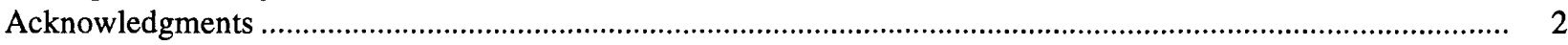

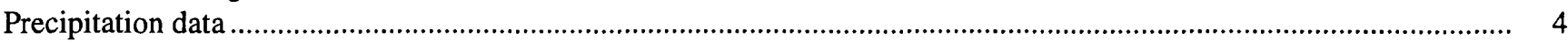

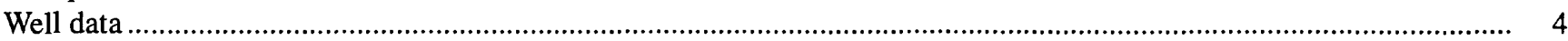

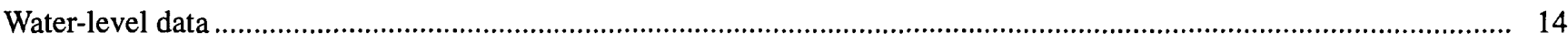

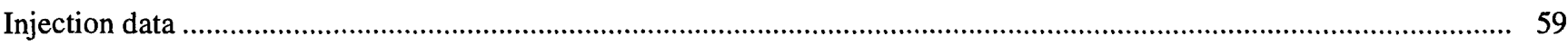

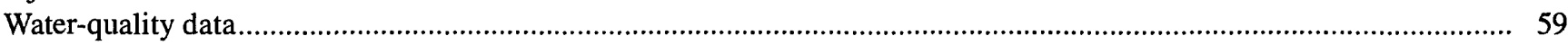

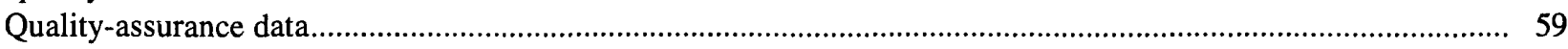

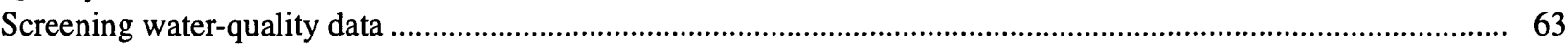

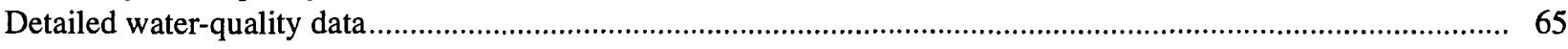

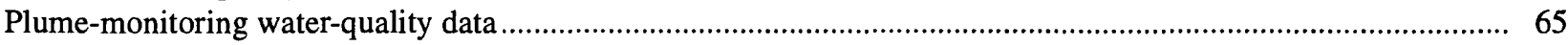

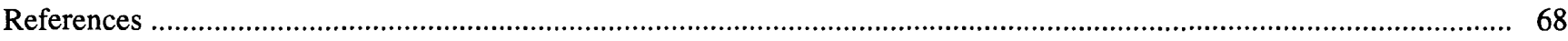

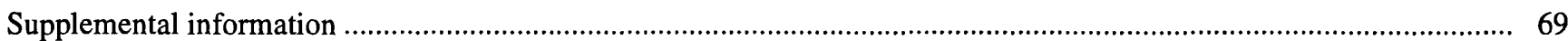

\section{ILLUSTRATIONS}

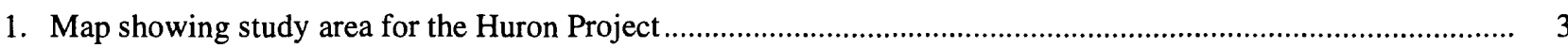

2. Map showing location of precipitation stations within the study area ......................................................... 5

3. Map showing location of selected South Dakota Department of Environment and Natural

Resources observation wells within the study area ........................................................................................... 8

4. Maps showing location of Huron Project observation wells, test holes, and recharge well within

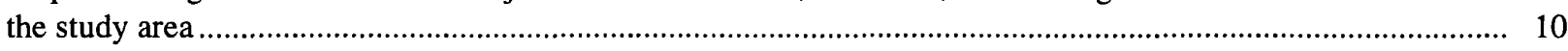

5-71. Hydrographs for observation wells:

5. 110N61W19AAAA, BD-60H, water years 1994-96 …................................................................... 15

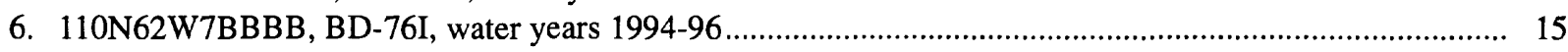

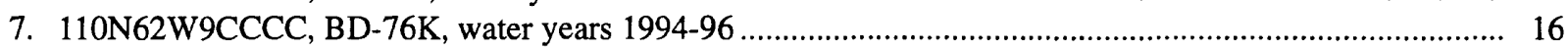

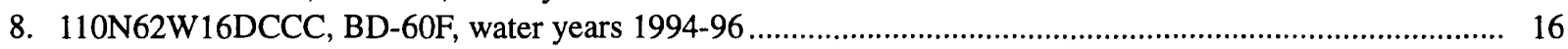

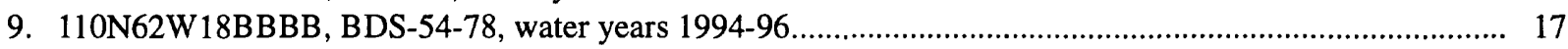

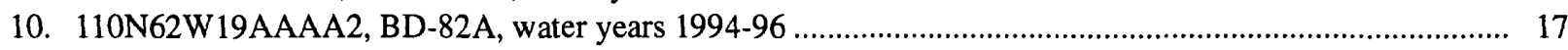

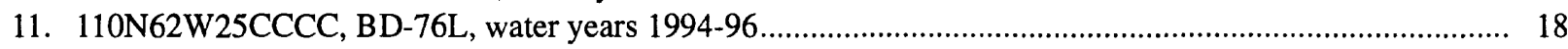

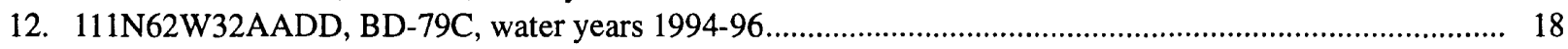

13. 111N62W32ADAA, BD-60D, water years 1994-96 ............................................................................. 19

14. 111N63W2CCCC, BD-60A, water years 1994-96 ............................................................................... 19

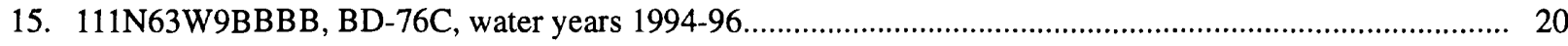

16. 111N63W12AAAA, BD-79A, water years 1994-96 .............................................................................. 20

17. 111N63W14CCCC, BD-79B, water years 1994-96 ............................................................................... 21

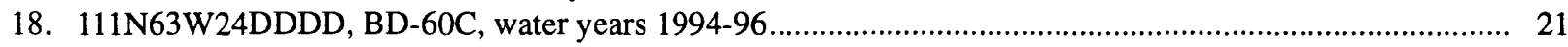

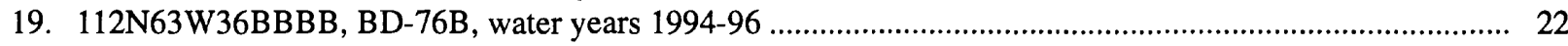

20. 110 N62W2BCCC2, CO-29-90, water years 1994-96 ........................................................................... 23

21. 110N62W3DCCC2, CO-27-90, water years 1994-96............................................................................ 23

22. 110N62W4AADA, CO-24-90, water years 1994-96 ............................................................................. 24

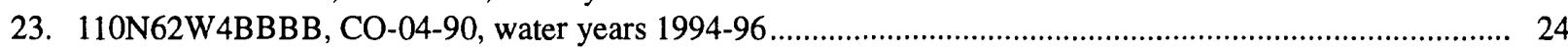

24. 110N62W4CDDD, CO-15-90, water years 1994-96 ........................................................................ 25

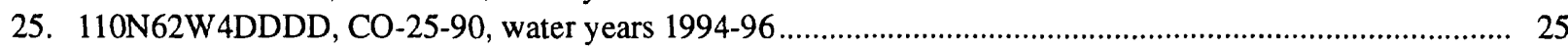

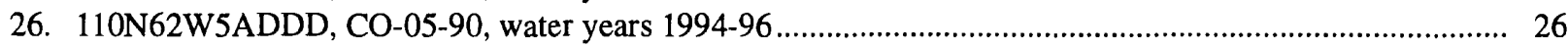

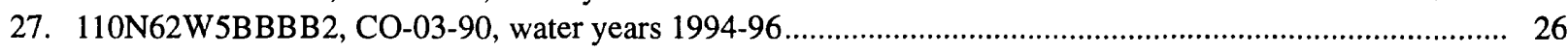




\section{ILLUSTRATIONS-Continued}

28. 110N62W5CCCB2, CO-31-90, water years 1994-96

29. 110N62W5DCCC, CO-14-90, water years 1994-96

30. 110N62W6BBBB, CO-23-90, water years 1994-96

31. 110N62W8CCCC, CO-01-90, water years 1994-96

32. 110N62W9BABB, CO-06-90, water years 1994-96

33. 110N62W9BBAC, CO-55-90, water years 1994-96

34. 110N62W9BBBA, CO-65-90, water years 1994-95

35. 110N62W9BBBA2, CO-66-90, water years 1994-96

36. 110N62W9BBBA3, CO-67-90, water years 1994-95

37. 110 N62W9BBBA4, A-01-90, water years 1994-96

38. 110N62W9BBBA5, A-02-90, water years 1994-96

39. 110N62W9BBBA6, A-03-90, water years 1994-96

40. 110N62W9BBBA7, A-04-90, water years 1994-96

41. 110N62W9BBBB2, CO-08-90, water years 1994-96

42. 110N62W9BBBC, CO-16-90, water years 1994-96

43. 110N62W9BBBC2, CO-33-90, water years $1994-95$

44. 110N62W9BBBC3, CO-34-90, water years 1994-95

45. 110N62W9BBBC4, CO-35-90, water years $1994-96$

46. 110N62W9BBBC5, CO-36-90, water years 1994-96

47. 110N62W9BBBC6, CO-37-90, water years 1994-96

48. 110N62W9BBBC7, CO-38-90, water years 1994-96

49. 110N62W9BBBD, CO-45-90, water years 1994-96

50. $110 \mathrm{~N} 62 \mathrm{~W} 9 \mathrm{BBBD} 3, \mathrm{CO}-47-90$, water years $1994-95$

51. 110N62W9BBBD4, CO-48-90, water years 1994-95

52. 110N62W9BBBD5, CO-49-90, water years 1994-95

53. $110 \mathrm{~N} 62 \mathrm{~W} 9 \mathrm{BBBD} 6, \mathrm{CO}-50-90$, water years $1994-96$

54. 110N62W9BBBD7, CO-51-90, water years 1994-95

55. 110N62W9BBCA, CO-52-90, water years 1994-95

56. $110 \mathrm{~N} 62 \mathrm{~W} 9 \mathrm{BBCA} 2, \mathrm{CO}-53-90$, water years $1994-96$

57. $110 \mathrm{~N} 62 \mathrm{~W} 9 \mathrm{BBCA} 3, \mathrm{CO}-54-90$, water years $1994-95$

58. 110N62W9BBCB, CO-18-90, water years 1994-96

59. 110N62W9BBCB2, CO-39-90, water years 1994-95

60. 110N62W9BBCB3, CO-40-90, water years 1994-95

61. 110N62W9BBCB4, CO-41-90, water years 1994-96

62. 110N62W9BBCB5, CO-42-90, water years 1994-96

63. 110N62W9BBCB6, CO-43-90, water years 1994-96

64. 110N62W9BBCB7, CO-44-90, water years 1994-96

65. 110N62W9BBCB8, CO-17-90, water years 1994-96

66. 110N62W9BBCB9, CO-63-90, water years 1994-95

67. 110N62W9BBCB 10, CO-64-90, water years 1994-95

68. 110N62W9BBCB11, CO-62-90, water years 1994-96

69. 110N62W9BBCB12, CO-57-90, water years 1994-95

70. 110N62W9BBCB13, CO-58-90, water years 1994-95

71. $110 \mathrm{~N} 62 \mathrm{~W} 9 \mathrm{BBCB} 14, \mathrm{CO}-56-90$, water years $1994-96$

72. Hydrograph for recharge well 110N62W9BBCB15, water years 1994-96 .................................................... 49

73-90. Hydrographs for observation wells:

73. 110N62W9BBCC, CO-59-90, water years 1994-96

74. 110 N62W9BBCC2, CO-60-90, water years 1994-95

75. $110 \mathrm{~N} 62 \mathrm{~W} 9 \mathrm{BBCC} 3$, CO-61-90, water years $1994-95$

76. 110 N62W9BBCC4, A-05-90, water years 1994-96

77. 110 N62W9BBCC5, A-06-90, water years 1994-96

78. 110 N62W9BBCC6, A-07-90, water years 1994-96

79. $110 \mathrm{~N} 62 \mathrm{~W} 9 \mathrm{BBCC}, \mathrm{A}-08-90$, water years $1994-96$ 


\section{ILLUSTRATIONS-Continued}

80. 110N62W9BBCC8, CO-09-90, water years 1994-96 ............................................................................ 53

81. 110N62W9BBDD, CO-19-90, water years 1994-96 ............................................................................ 53

82. 110N62W9BCAB, CO-32-90, water years 1994-96 ........................................................................... 54

83. 110N62W9BCBC, CO-68-90, water years 1994-96 …............................................................................ 54

84. 110N62W9BCDD, CO-10-90, water years 1994-96 ....................................................................... 55

85. 110N62W10CCCC, CO-11-90, water years 1994-95 …........................................................................ 55

86. 110N62W10DDDD, CO-12-90, water years 1994-96 ......................................................................... 56

87. 110N62W16BBAA, CO-13-90, water years 1994-96 ........................................................................ 56

88. 110N62W21AAAA, CO-21-90, water years 1994-96 ..................................................................... 57

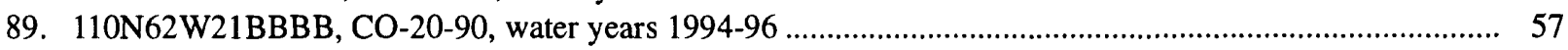

90. 110N62W22AAAA, CO-22-90, water years 1994-96 ........................................................................ 58

91. Graphs showing injection rate and cumulative volume of injected recharge water for 1994 recharge period ........ 60

92. Graphs showing injection rate and cumulative volume of injected recharge water for 1995 recharge period ........ 61

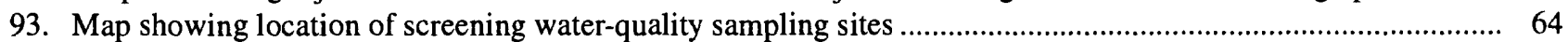

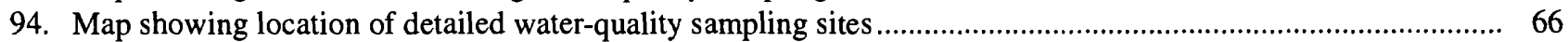

95. Map showing location of plume-monitoring water-quality sampling sites ..................................................... 67

\section{TABLES}

1. Daily precipitation data for the Huron National Weather Service station, October 1993 through September 1995

2. Selected site data for South Dakota Department of Environment and Natural Resources observation wells

3. Selected site data for Huron Project observation wells, test holes, and recharge well

4. Concentrations of inorganic constituents obtained from quality-assurance sample blanks .............................. 62

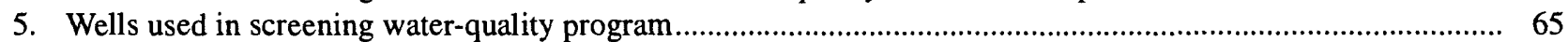

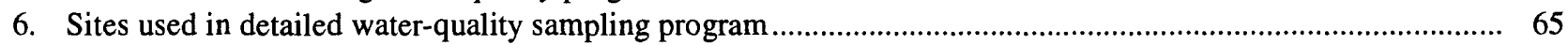

7. Sites used in plume-monitoring water-quality sampling program ............................................................. 68

8. Water-quality data obtained from screening samples …........................................................................... 70

9. Physical properties and concentrations of inorganic constituents, radioactive nuclides, and total organic carbon obtained from detailed samples....

10. Concentrations of dicamba, picloram, and chlorophenoxy-acid herbicides obtained from detailed samples........ 101

11. Concentrations of organochlorine insecticides, gross polychlorinated biphenols (PCB's), and gross polychlorinated naphthalenes (PCN's) obtained from detailed samples.

12. Concentrations of volatile organic compounds obtained from detailed samples .............................................. 104

13. Water-quality data obtained from plume-monitoring samples .................................................................. 110 
CONVERSION FACTORS AND VERTICAL DATUM

\begin{tabular}{rcl}
\hline Multiply & By & To obtain \\
\hline foot & 0.3048 & meter \\
mile & 1.609 & kilometer \\
inch & 25.4 & millimeter \\
inch & 2.54 & centimeter \\
\hline
\end{tabular}

Temperature can be converted to degrees Fahrenheit $\left({ }^{\circ} \mathrm{F}\right)$ or degrees Celsius $\left({ }^{\circ} \mathrm{C}\right)$ by the following equations:

$$
\begin{aligned}
& { }^{\circ} \mathrm{F}=9 / 5\left({ }^{\circ} \mathrm{C}\right)+32 \\
& { }^{\circ} \mathrm{C}=5 / 9\left({ }^{\circ} \mathrm{F}-32\right)
\end{aligned}
$$

Sea level: In this report, "sea level" refers to the National Geodetic Vertical Datum of 1929--a geodetic datum derived from a general adjustment of the first-order level nets of the United States and Canada, formerly called Sea Level Datum of 1929.

Water year: Water year is the 12-month period, October 1 through September 30, and is designated by the calendar year in which it ends. Thus, the water year ending September 30,1995, is called the "1995 water year." 


\title{
Hydrologic Data for 1994-96 for the Huron Project of the High Plains Ground-Water Demonstration Program
}

\author{
By Janet M. Carter
}

\section{ABSTRACT}

This report presents data on precipitation, water levels, and water quality that have been collected or compiled for water years 1994 through 1996 for the Huron Project of the High Plains Ground-Water Demonstration Program, under the guidance of the Bureau of Reclamation. This is the second report for the project. The first report (Carter, 1995) presented data collected through water year 1993.

The purpose of the Huron Project is to demonstrate the artificial recharge potential of glacial aquifers in eastern South Dakota. High flows from the James River during spring runoff were used as a source of supplemental recharge for the Warren aquifer, which is a buried, glacial aquifer. In 1990, 70 observation wells were installed by the South Dakota Department of Environment and Natural Resources (DENR) specifically for this study, and 15 existing DENR observation wells were incorporated into the study. In 1993, the recharge well was installed. After a trial injection of recharge water in April 1994, continuous injection began in June 1994. Many sites were monitored to obtain information before, during, and after recharging the aquifer. This report presents data that were collected during the three phases of recharge.

Precipitation data are collected at two sites within the study area. A site description and daily precipitation for water years 1994-95 are presented for one precipitation site. Water-level hydrographs are presented for the 85 observation wells and the recharge well. Hydrographs are shown for the period from October 1, 1993, through November 29, 1995. Recharge water was injected from June 2, 1994, through July 29, 1994, and from June 14, 1995, through

September 13, 1995. The cumulative volume of injected water and the injection rates into the aquifer are presented for the periods of recharge.

Water-quality data were collected from screening, detailed, and plume-monitoring sampling programs. Screening water-quality data for six observation wells are presented. These data include primarily field parameters and common ions. The four detailed sampling sites represent the quality of untreated water, treated water, and ground water from the Warren aquifer. Data presented for the detailed sampling program include field parameters, bacteria counts, and concentrations of common ions, solids, nutrients, trace elements, radiometrics, total organic carbon, herbicides, insecticides, and volatile organic compounds. Water-quality data for the plumemonitoring sampling program were collected from 25 sites during injection of recharge water into the Warren aquifer in 1994 and 1995. The data for the plume-monitoring program include primarily field parameters and common ions. Data for qualityassurance samples also are presented.

\section{INTRODUCTION}

The Huron Project of the High Plains GroundWater Demonstration Project was initiated in 1990 as a cooperative effort between South Dakota State University (SDSU), the Bureau of Reclamation, the U.S. Geological Survey (USGS), the U.S. Environmental Protection Agency, the South Dakota Department of 
Environment and Natural Resources (DENR), and the city of Huron. The purpose of the study is to demonstrate the artificial recharge potential of glacial aquifers in eastern South Dakota.

The Huron Project is designed to use high flows from the James River during spring runoff as a source of supplemental recharge for the Warren aquifer, which is a buried, glacial aquifer. During the spring runoff period, water is pumped from the James River to the city of Huron's water treatment plant. After treatment, it is piped to the Huron well field and injected into the aquifer using a recharge well (fig. 1). During periods of low flow, the city of Huron can pump water from the aquifer and return it to the water treatment plant using the same pipeline. A trial injection of recharge water was conducted in April 1994; continuous injection began in June 1994.

Numerous observation wells existed in the study area prior to the inception of the Huron Project, and 15 DENR observation wells were incorporated into the study. In 1990, 76 test holes were drilled and observation wells were installed at 70 sites to provide a more comprehensive monitoring network. The recharge well was installed in 1993. Water levels were measured biweekly, beginning in 1991 for the DENR wells and new observation wells and beginning in 1994 for the recharge well.

Recharge water was injected from June 2, 1994, through July 29, 1994, and from June 14, 1995, through September 13, 1995. The cumulative volume of injected water and the injection rates into the aquifer were frequently monitored during the recharge phase.

In 1991, screening and detailed sampling programs were initiated to collect background waterquality data. The screening samples were collected monthly and were analyzed for a limited parameter set. The detailed samples were collected quarterly and were analyzed for an extensive parameter set. In 1994, a plume-sampling program was initiated to monitor the movement of the recharge plume from the recharge well to other wells located in the Huron well field. These samples were collected several times a week when water was being injected into the Warren aquifer during the summers of 1994 and 1995.

The purpose of this report is to present precipitation, water-level, and water-quality data that have been collected or compiled for the Huron Project for water years 1994 through 1996. Specifically, this report contains: (1) precipitation records for one site;

(2) hydrographs for 85 observation wells and the recharge well; (3) graphs showing the cumulative volume of injected water and injection rates for the two periods of recharge during 1994 and 1995; and

(4) screening water-quality data for six sites, detailed water-quality data for four sites, and plume-monitoring water-quality data for 25 sites.

\section{Description of Study Area}

The study area is located in the James River Basin near Huron, South Dakota, as shown in figure 1. The James River Basin is a north-south trending lowland that separates two coteaus, the Coteau du Missouri and the Coteau des Prairies. Advancement and recession of glaciers during the Wisconsin age of the Pleistocene epoch created the James River Basin (Flint, 1955).

The Huron well field is located 3 miles west of Huron. The city of Huron operates six production wells located in and near the well field (fig. 1), normally from October 1 to April 1. This schedule enables the Huron Project to inject recharge water when the city is not producing water from the well field.

In addition to the city production wells, a stock well is located within the well field (fig. 1). This site was used in the earlier detailed sampling program because it was the only well in the well field that could be sampled prior to the drilling of additional observation wells during 1990. In 1992, the collection of water samples was discontinued at this site (see Carter, 1995, for water-quality data collected at this site).

The recharge site, which is located in the Huron well field, is in a glacial drift region with interbedded till and outwash. The city production wells, stock well, and recharge well are completed in an outwash aquifer, locally known as the Warren aquifer (Schaefer and others, 1990). The Warren aquifer is of Pleistocene age and is described in Steece and Howells (1965) and Howells and Stephens (1968). The Pierre Shale and the Niobrara Formation, two bedrock units of Cretaceous age, underlie the glacial drift in the study area.

\section{Acknowledgments}

Many people have assisted with development and implementation of the Huron Project. In particular, Vernon R. Schaefer and Delvin E. DeBoer, the principal project investigators, were largely responsible for 


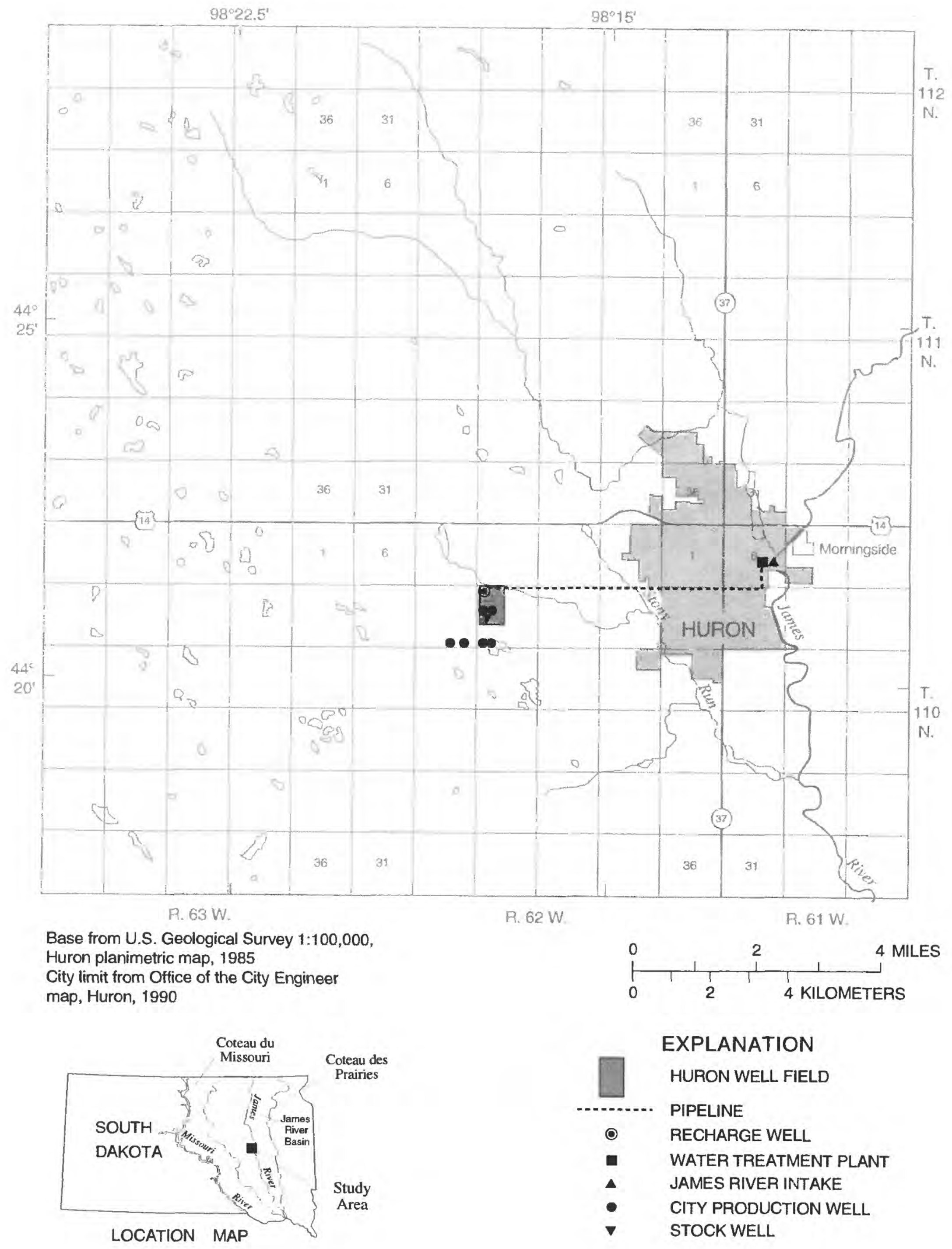

Figure 1. Study area for the Huron Project. 
the development and execution of the project. Several graduate students from the Civil Engineering Department at South Dakota State University provided valuable assistance with the collection and analyses of data. The students that collected data presented in this report included Seth Peterson and John Graupman. Herb Scheele and the operators at the Huron Water Treatment Plant provided valuable aid in the collection of water samples from the James River and the treatment plant. The South Dakota Geological Survey drilled the test holes and installed the observation wells for the project.

\section{PRECIPITATION DATA}

Precipitation data are collected at two sites in the study area (fig. 2). Precipitation data are collected at an acid-rain station located in the Huron well field as part of the National Atmospheric Deposition Program and National Trends Network. The daily precipitation data for this site have been published annually in Water Resources Data for South Dakota (U.S. Geological Survey, 1987-95). USGS personnel have been responsible for maintenance of the acid-rain station and collection of precipitation data.

The National Weather Service operates the other precipitation station, which is located at the Huron Regional Airport. Daily precipitation data for the Huron weather station, compiled from monthly summaries (U.S. Department of Commerce, 1993-95) for water years 1994 through 1995, are presented in table 1 . The period of record presented corresponds to the collection of water-level and water-quality data for the Huron Project presented in this report.

\section{WELL DATA}

Prior to the inception of the Huron Project, numerous DENR observation wells existed within the study area. Fifteen of these wells were incorporated into the study. The locations of the DENR observation wells utilized for the study are shown in figure 3; selected site data for these wells are presented in table 2. The two aquifers that supply the DENR observation wells are the Warren and Pleistocene aquifers, with the exception of well BDS-54-78, where the aquifer is unknown (table 2). As previously stated, the Warren aquifer is of Pleistocene age. The Pleistocene aquifer has not been differentiated but is of the same age as the Warren aquifer.
Three methods of station identification are presented in table 2. The first method is the station identification number, which is based on the international system of latitude and longitude. The number contains 15 digits. The first six digits denote the degrees, minutes, and seconds of latitude north of the equator. The next seven digits denote the degrees, minutes, and seconds of longitude west of the prime (Greenwich) meridian. The last two digits are sequential numbers for wells within the same latitude and longitude.

The second identification method presented in table 2 is the local number, which is based on the Federal land-survey system of eastern South Dakota (shown below). The local number consists of the township number followed by " $\mathrm{N}$," range number followed by "W," and section number, followed by a maximum of four uppercase letters that indicate, respectively, the $160-, 40-, 10$, and 2.5-acre tract in which the well is located. These letters are assigned in a counterclockwise direction beginning with " $A$ " in the northeast quarter. A serial number following the last letter is used to distinguish between wells in the same 2.5-acre tract. Thus, well 111N62W32AADD is in the $\mathrm{SE}^{1 / 4}$ of the $\mathrm{SE}^{1 / 4}$ of the $\mathrm{NE}^{1 / 4}$ of the $\mathrm{NE}^{1 / 4}$ of section 32 in township 111 north and range 62 west.

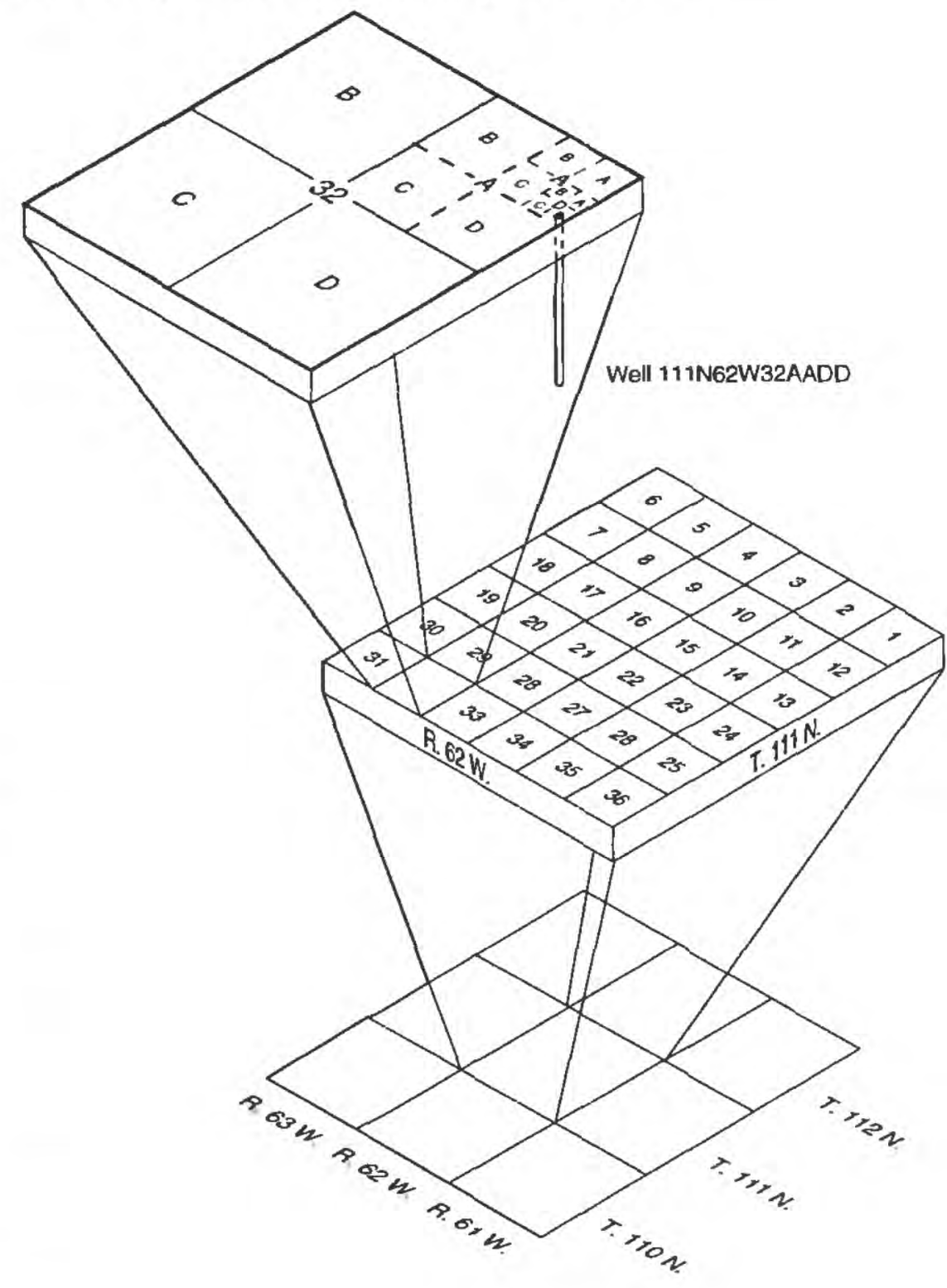




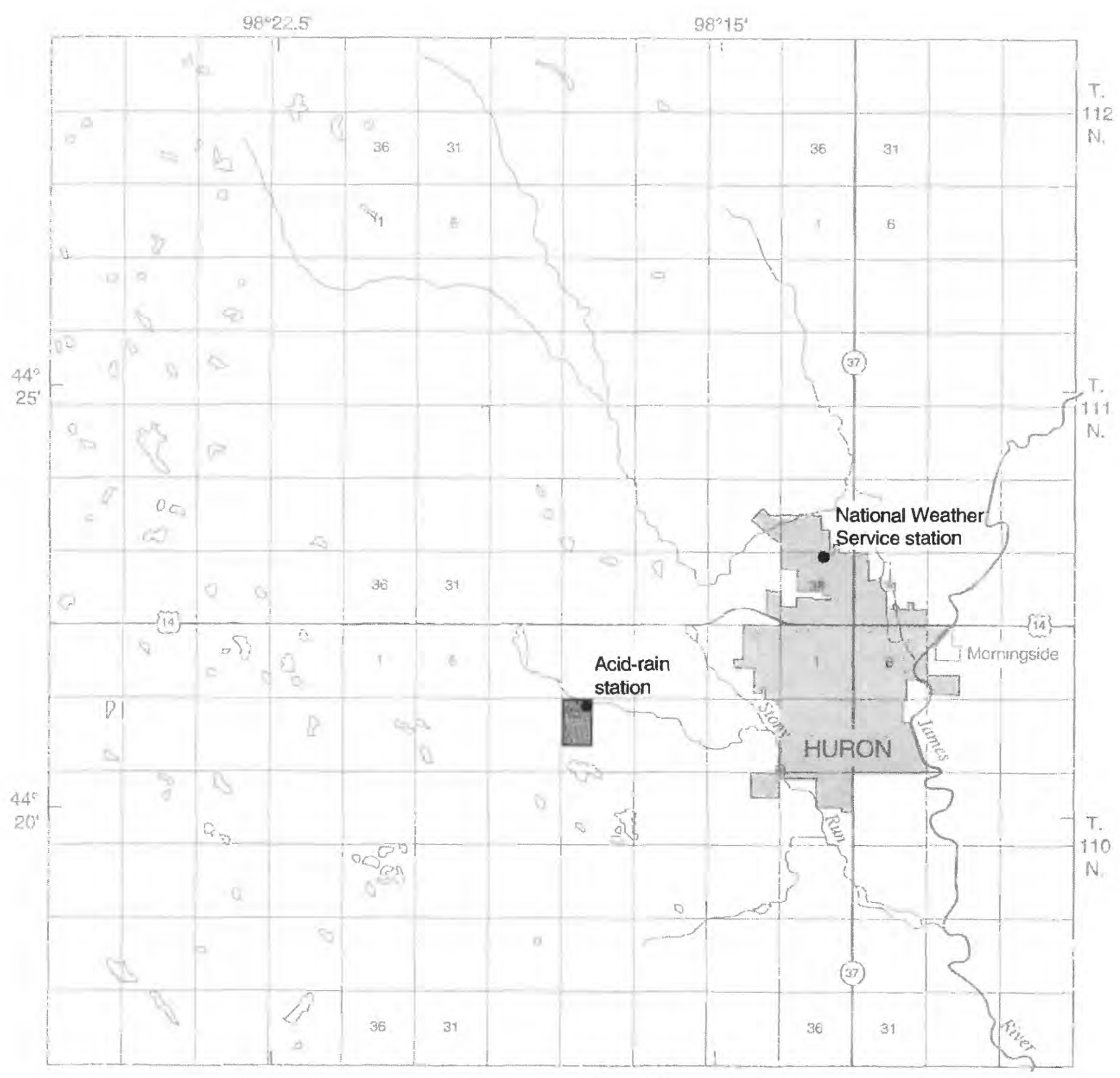

P. $63 \mathrm{~W}$.

A. $62 \mathrm{~W}$.

R. 61 W.

Base from U.S. Geological Survey 1:100,000,

Huron planimetric map, 1985

City limit from Office of the City Engineer

map, Huron, 1990

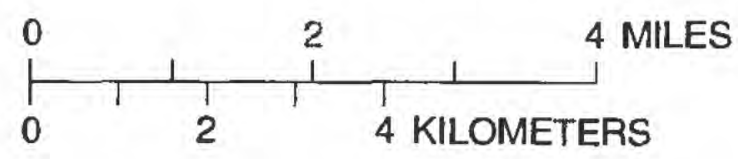

\section{EXPLANATION}

HURON WELL FIELD

- PRECIPITATION STATION

Figure 2. Location of precipitation stations within the study area. 
Table 1. Daily precipitation data for the Huron National Weather Service station, October 1993 through September 1995 $[\mathrm{T}$, trace; --, no data]

PRECIPITATION, IN INCHES, WATER YEAR OCTOBER 1993 THROUGH SEPTEMBER 1994

\begin{tabular}{|c|c|c|c|c|c|c|c|c|c|c|c|c|}
\hline DAY & OCT & NOV & DEC & JAN & FEB & MAR & APR & MAY & JUN & JUL & AUG & SEP \\
\hline 1 & 0.00 & .00 & .00 & $T$ & .01 & $T$ & .00 & $T$ & .13 & .21 & .00 & .29 \\
\hline 2 & .00 & .00 & .00 & .10 & $T$ & .00 & .00 & .07 & $T$ & .00 & .00 & .68 \\
\hline 3 & .00 & .00 & .00 & .04 & .00 & .00 & .00 & $T$ & .00 & .10 & .00 & .76 \\
\hline 4 & .00 & .05 & .00 & $T$ & .00 & .00 & .09 & .00 & .90 & $\mathrm{~T}$ & .00 & $\mathbf{T}$ \\
\hline 5 & .00 & $T$ & .12 & .05 & .00 & $\mathrm{~T}$ & .00 & .01 & .99 & .00 & $\mathrm{~T}$ & .00 \\
\hline 6 & .00 & .00 & .00 & $T$ & $T$ & $T$ & .00 & .10 & .07 & 1.16 & .00 & .00 \\
\hline 7 & .00 & $\mathbf{T}$ & .00 & .00 & .04 & .00 & .00 & .00 & .01 & .24 & .02 & .00 \\
\hline 8 & .57 & $T$ & .00 & .01 & .24 & $\mathrm{~T}$ & .08 & .00 & .03 & .05 & .00 & .00 \\
\hline 9 & .00 & .00 & .00 & $\mathrm{~T}$ & .00 & .07 & .00 & .00 & .00 & .00 & .93 & .00 \\
\hline 10 & .00 & .00 & $T$ & $T$ & .00 & .00 & .00 & .00 & .08 & .00 & .16 & .00 \\
\hline 11 & .00 & .00 & .00 & .00 & .05 & .00 & .00 & $\mathbf{T}$ & .00 & $\mathrm{~T}$ & .01 & .00 \\
\hline 12 & .00 & 1.29 & .00 & $\mathrm{~T}$ & $\mathrm{~T}$ & .00 & .00 & .00 & .10 & .00 & $T$ & $T$ \\
\hline 13 & .00 & .02 & $\mathbf{T}$ & .07 & .00 & .00 & .00 & .91 & .00 & .47 & .01 & .05 \\
\hline 14 & .00 & .00 & $T$ & .00 & .00 & .00 & .45 & .34 & $\mathrm{~T}$ & .00 & .00 & $\mathrm{I}$ \\
\hline 15 & .06 & .00 & .00 & .00 & .00 & .00 & .00 & .00 & .64 & .10 & .00 & .05 \\
\hline 16 & $\mathrm{~T}$ & .00 & .06 & .04 & .00 & .00 & .00 & .00 & .28 & .00 & .00 & .00 \\
\hline 17 & .00 & .00 & .11 & $T$ & .00 & $\mathrm{~T}$ & .00 & $\mathrm{~T}$ & .94 & .00 & .00 & .00 \\
\hline 18 & .00 & .00 & $T$ & $T$ & $\mathbf{T}$ & .00 & $\mathbf{T}$ & .00 & $\mathrm{~T}$ & .50 & .01 & .00 \\
\hline 19 & .00 & .00 & $T$ & .05 & $T$ & $T$ & .00 & .00 & .40 & .10 & .00 & .00 \\
\hline 20 & $\mathrm{~T}$ & .00 & $\mathbf{T}$ & .00 & .00 & .11 & .09 & .00 & $\mathrm{~T}$ & .00 & .00 & $\mathbf{T}$ \\
\hline 21 & .00 & .00 & .21 & .00 & $\mathrm{~T}$ & .00 & .00 & .12 & .00 & .00 & .00 & .09 \\
\hline 22 & .00 & .01 & $\mathrm{~T}$ & .00 & .19 & .00 & .00 & .00 & .53 & .00 & $T$ & .00 \\
\hline 23 & .00 & .05 & .00 & .00 & .07 & .03 & .00 & .00 & .00 & .00 & $\mathbf{T}$ & .00 \\
\hline 24 & .00 & .23 & .11 & $\mathrm{~T}$ & .09 & .00 & $\mathrm{~T}$ & $\mathbf{T}$ & .00 & .00 & $\mathbf{T}$ & .00 \\
\hline 25 & .00 & .06 & $\mathrm{~T}$ & $T$ & .01 & $\mathbf{T}$ & .56 & .12 & .02 & $T$ & .00 & .00 \\
\hline 26 & .00 & .06 & .02 & .05 & .00 & $T$ & 1.11 & .00 & .00 & $T$ & .00 & .00 \\
\hline 27 & .00 & .01 & $T$ & .43 & $T$ & .06 & $T$ & .00 & $\mathrm{~T}$ & .00 & .00 & .00 \\
\hline 28 & .00 & .00 & .00 & .09 & $T$ & $T$ & .37 & .00 & .00 & .00 & .00 & .00 \\
\hline 29 & $T$ & .00 & .02 & $\mathrm{~T}$ & -- & $T$ & $T$ & .00 & .00 & .00 & .13 & .00 \\
\hline 30 & .00 & .00 & .04 & $T$ & -- & .00 & .00 & .00 & .00 & .02 & $\mathbf{T}$ & .00 \\
\hline 31 & .00 & -- & .03 & $T$ & -- & .00 & -- & .00 & -- & .00 & .00 & $\cdots$ \\
\hline Total & .63 & 1.78 & .72 & .93 & .70 & .27 & 2.75 & 1.67 & 5.12 & 2.95 & 1.27 & 1.92 \\
\hline
\end{tabular}


Table 1. Daily precipitation data for the Huron National Weather Service station, October 1993 through September 1995-Continued

PRECIPITATION, IN INCHES, WATER YEAR OCTOBER 1994 THROUGH SEPTEMBER 1995

\begin{tabular}{|c|c|c|c|c|c|c|c|c|c|c|c|c|}
\hline DAY & OCT & NOV & DEC & JAN & FEB & MAR & APR & MAY & JUN & JUL & AUG & SEP \\
\hline 1 & .02 & $\mathbf{T}$ & .00 & $T$ & .02 & .00 & .00 & .11 & .00 & .00 & .00 & .00 \\
\hline 2 & .70 & .00 & .00 & .01 & $\mathrm{~T}$ & .00 & .00 & $\mathrm{~T}$ & .00 & .00 & .00 & .00 \\
\hline 3 & .03 & .00 & .00 & .00 & $\mathrm{~T}$ & .00 & .00 & .02 & .00 & .94 & .11 & $\mathrm{~T}$ \\
\hline 4 & $\mathrm{~T}$ & .00 & .02 & .00 & $\mathrm{~T}$ & .25 & $\mathrm{~T}$ & .00 & .03 & .09 & 1.74 & .00 \\
\hline 5 & .00 & .00 & $\mathrm{~T}$ & .00 & .03 & .06 & .00 & .00 & .00 & .15 & .18 & .69 \\
\hline 6 & .36 & .00 & .02 & $T$ & .04 & .08 & .00 & .32 & .00 & .00 & $T$ & .02 \\
\hline 7 & .05 & .00 & .04 & .00 & .01 & $T$ & .26 & .01 & .88 & $T$ & .00 & .00 \\
\hline 8 & .00 & .00 & .04 & $\mathrm{~T}$ & .00 & .00 & .23 & .94 & .10 & $T$ & .00 & .00 \\
\hline 9 & .00 & .00 & .00 & .00 & .00 & .00 & .54 & 1.18 & .55 & .00 & .00 & .00 \\
\hline 10 & .00 & .00 & .00 & $\mathrm{~T}$ & $T$ & .00 & .46 & $\mathrm{~T}$ & .17 & .00 & .00 & .00 \\
\hline 11 & .00 & .00 & $T$ & .00 & $T$ & .00 & .39 & .00 & .00 & .00 & $\mathbf{T}$ & .09 \\
\hline 12 & .00 & .02 & .00 & .18 & .00 & .00 & .11 & .49 & .00 & $T$ & .00 & $\mathbf{T}$ \\
\hline 13 & .00 & $T$ & $T$ & .00 & $T$ & .00 & .00 & .44 & .00 & .00 & .32 & .00 \\
\hline 14 & .00 & .00 & .44 & $T$ & .07 & .00 & .00 & .00 & .00 & .00 & .00 & .00 \\
\hline 15 & .23 & .00 & $T$ & $T$ & .03 & .00 & .36 & .00 & .08 & .03 & .00 & .30 \\
\hline 16 & .22 & .00 & .00 & .01 & $\mathrm{~T}$ & .00 & .00 & .05 & .00 & .00 & .00 & .00 \\
\hline 17 & .41 & $\mathrm{~T}$ & .00 & .26 & .00 & .15 & .16 & .00 & .00 & .00 & .00 & .00 \\
\hline 18 & .00 & .04 & .00 & .00 & .00 & .03 & 1.82 & .00 & .00 & .00 & $\mathrm{~T}$ & .21 \\
\hline 19 & .00 & .00 & .00 & $T$ & $T$ & .00 & .00 & .00 & .00 & .36 & .00 & .00 \\
\hline 20 & .00 & .15 & .00 & $\mathrm{~T}$ & .00 & $\mathrm{~T}$ & .01 & .00 & .00 & .00 & .00 & .00 \\
\hline 21 & .00 & .00 & .00 & $T$ & .00 & .00 & $T$ & $\mathrm{~T}$ & $\mathrm{~T}$ & $T$ & .00 & .08 \\
\hline 22 & $\mathrm{~T}$ & .00 & .00 & $\mathrm{~T}$ & .00 & .17 & .00 & .31 & .32 & .14 & .00 & .00 \\
\hline 23 & .00 & .00 & .00 & .01 & $T$ & .00 & .31 & .00 & $\mathrm{~T}$ & .04 & .00 & .00 \\
\hline 24 & .00 & .00 & .00 & $\mathrm{~T}$ & .00 & .00 & .00 & .00 & .00 & .00 & $\mathrm{~T}$ & .00 \\
\hline 25 & .00 & .00 & .00 & .01 & .00 & 1.06 & $\mathrm{~T}$ & $\mathrm{~T}$ & .00 & .17 & .30 & .00 \\
\hline 26 & .00 & .05 & .00 & .00 & $T$ & 1.13 & $\mathrm{~T}$ & .49 & .00 & .00 & .00 & .00 \\
\hline 27 & .00 & .33 & .00 & .00 & .03 & .29 & .00 & 2.00 & .07 & .16 & .00 & .00 \\
\hline 28 & $T$ & .01 & .00 & $T$ & $\mathrm{~T}$ & .03 & .32 & .04 & .00 & .00 & $\mathrm{~T}$ & .00 \\
\hline 29 & .00 & .01 & .01 & $\mathbf{T}$ & - & $\mathbf{T}$ & .11 & .00 & .00 & .00 & .54 & .43 \\
\hline 30 & .00 & .00 & $\mathrm{~T}$ & .00 & -- & $T$ & .23 & .00 & .00 & .33 & .00 & 1.07 \\
\hline 31 & .00 & -- & $\mathrm{T}$ & $\mathrm{T}$ & -- & .00 & -- & .00 & $\ldots$ & .46 & .00 & -. \\
\hline Total & 2.02 & .61 & .57 & .48 & .23 & 3.25 & 5.31 & 6.40 & 2.20 & 2.87 & 3.19 & 2.89 \\
\hline
\end{tabular}




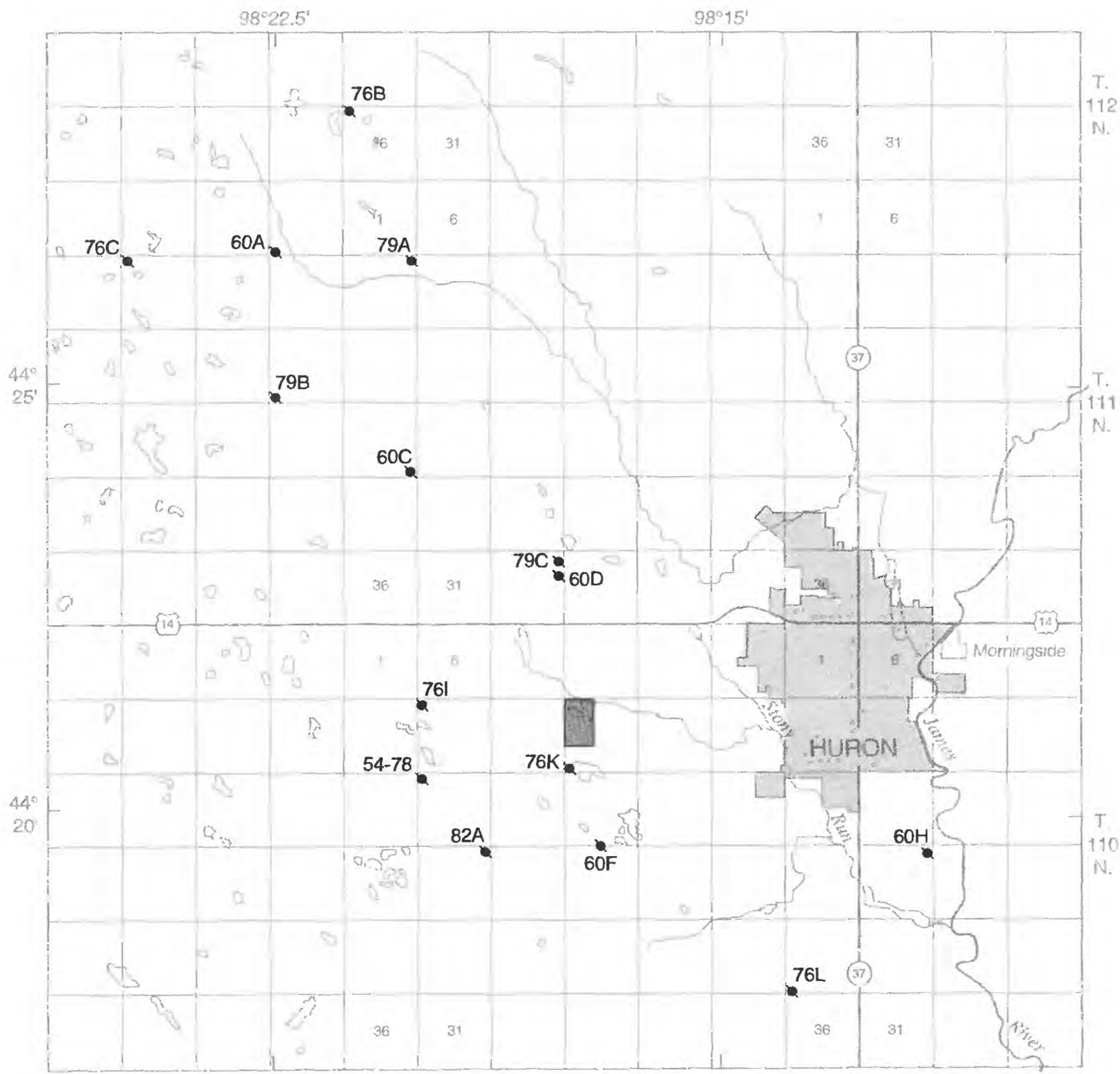

\section{R. $63 \mathrm{~W}$.}

Base from U.S. Geological Survey 1:100,000, Huron planimetric map, 1985 City limit from Office of the City Engineer map, Huron, 1990
R. 62 W.

1 
Tabla 2. Selected site data for South Dakota Department of Environment and Natural Resources observation wells [Other identifier: BD or BDS, Beadle County. All values in feet below or above (-) land surface. --, no data]

\begin{tabular}{cllllcccc}
\hline $\begin{array}{c}\text { Station } \\
\text { identification } \\
\text { number }\end{array}$ & USGS local number & $\begin{array}{c}\text { Other } \\
\text { identifier }\end{array}$ & Aquifer & $\begin{array}{c}\text { Depth } \\
\text { drilled } \\
\text { (feet) }\end{array}$ & $\begin{array}{c}\text { Top } \\
\text { of casing } \\
\text { (feet) }\end{array}$ & $\begin{array}{c}\text { Bottom of } \\
\text { casing } \\
\text { (feet) }\end{array}$ & $\begin{array}{c}\text { Top } \\
\text { of screen } \\
\text { (feet) }\end{array}$ & $\begin{array}{c}\text { Bottom of } \\
\text { screen } \\
\text { (feet) }\end{array}$ \\
\hline 441935098114101 & 110 N61W19AAAA & BD-60H & Warren & -- & -- & -- & - & -- \\
442119098200701 & 110 N62W 7BBBB & BD-76I & Pleistocene & 90.0 & -1.30 & 58.70 & 58.70 & 63.70 \\
442033098174001 & 110 N62W 9CCCC & BD-76K & Warren & 110 & -1.50 & 88.50 & 88.50 & 93.50 \\
441941098170301 & 110 N62W16DCCC & BD-60F & Warren & 92.0 & -0.50 & 80.00 & -- & -- \\
442027098200701 & 110 N62W18BBBB & BDS-54-78 & -- & 40.0 & -2.50 & 37.00 & 17.00 & 37.00 \\
441935098185702 & 110 N62W19AAAA2 & BD-82A & Warren & -- & -- & -- & -- & -- \\
441757098135901 & 110 N62W25CCCC & BD-76L & Pleistocene & 90.0 & -0.20 & 68.80 & 68.80 & 73.80 \\
442254098174501 & 111 N62W32AADD & BD-79C & Warren & -- & -- & -- & - & -- \\
442250098174401 & 111 N62W32ADAA & BD-60D & Pleistocene & 130 & -2.00 & 63.00 & -- & - \\
442638098223301 & 111 N63W 2CCCC & BD-60A & Pleistocene & 100 & -0.98 & 58.00 & -- & -- \\
442632098250001 & 111 N63W 9BBBB & BD-76C & Pleistocene & 120 & -2.39 & 98.20 & 98.20 & 103.20 \\
442633098201101 & 111 N63W12AAAA & BD-79A & Warren & -- & -- & -- & -- & -- \\
442451098151501 & 111 N63W14CCCC & BD-79B & Warren & -- & -- & -- & -- & -- \\
442402098201101 & 111 N63W24DDDD & BD-60C & Pleistocene & 125 & -2.00 & 64.00 & -- & -- \\
442816098212001 & $112 N 63 W 36 B B B B$ & BD-76B & Pleistocene & 90.0 & -2.09 & 57.80 & 57.80 & 62.80 \\
\hline
\end{tabular}

The third identification method is the "other identifier," which was assigned by DENR (table 2). This name denotes the county in which the well is located followed by the year and sequence in which it was drilled.

In 1990, the South Dakota Geological Survey (SDGS) drilled 76 test holes within the study area. Observation wells subsequently were installed at 70 of these sites. The recharge well was completed in 1993. The locations of the observation wells, test holes, and recharge well are shown in figure 4 , and selected site data for the wells and test holes are presented in table 3.

The wells and test holes in table 3 are identified by the 15-digit station identification number based on their latitudes and longitudes, the USGS local number based on the Federal land-survey system, and the other identifier, all assigned by the same methods previously described. The other identifier (table 3 ) was designated by SDGS and denotes the drilling technique (CO: combination rig; A: auger rig) followed by the sequence and year in which it was drilled.

The observation wells and test holes were drilled with either a combination rotary or an auger rig. All well-drilling and completion materials were provided by SDGS. The eight wells that were constructed with an auger were drilled into the surficial till deposits and do not penetrate the Warren aquifer. The other 68 wells were constructed using hydraulic rotary techniques. Of these wells, 8 were completed in the till, 54 were completed in the Warren aquifer, and 6 were not completed because of drilling problems.

All completed wells have 2-inch PVC casing and screen. The wells were gravel packed with washed Platte River sand from Grand Island, Nebraska, and were sealed with bentonite to approximately 20 feet below land surface and with neat cement from the top of the bentonite to the land surface. The wells were developed using compressed air, after which 5-foot-tall metal protectors were installed over the top of each well.

Cuttings from the wells and test holes were collected at 5-foot intervals. The cuttings and information provided by the driller were used to prepare geologic logs of each of the wells and test holes, except for those completed in the till. Gamma logging was performed on most of the wells by USGS. The gamma logs are available for examination at the USGS office in Huron, South Dakota. The geologic logs of the observation wells and test holes are presented in Carter (1995). 


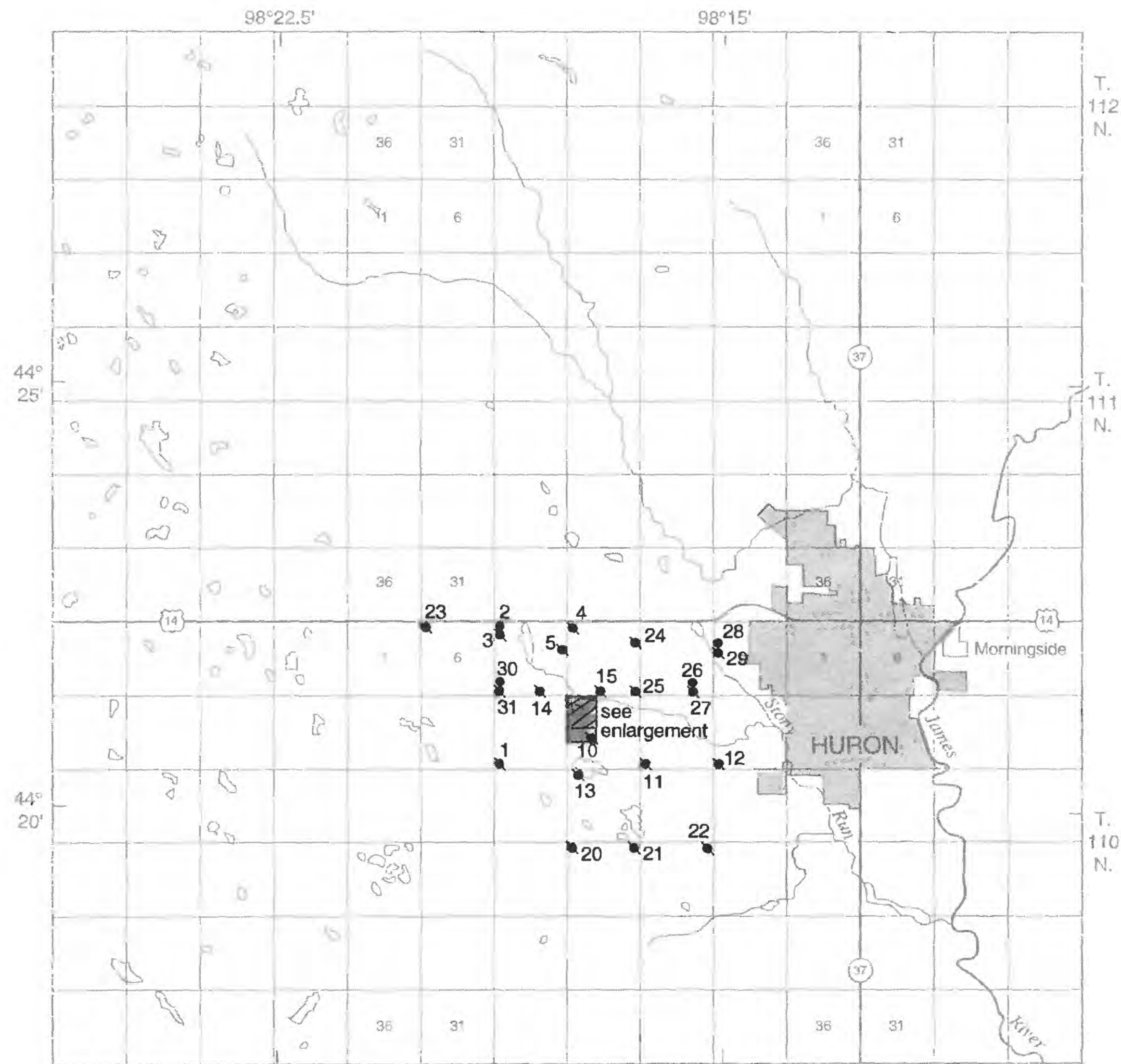

A. $63 \mathrm{~W}$.

Base from U.S. Geological Survey 1:100,000, Huron planimetric map, 1985 City limit from Office of the City Engineer map, Huron, 1990
R. 62 W.

\section{2}

\section{EXPLANATION}

HURON WELL FIELD

24 HURON PROJECT OBSERVATION WELL--Number corresponds to the middle number of the other identifier number in table 3

A1 HURON PROJECT OBSERVATION WELL--Letter denotes auger wells and number corresponds to the middle number of the other identifier number of the auger wells in table 3

- 2 HURON PROJECT TEST HOLE--Number corresponds to the middle number of the other identifier number in table 3

- RECHARGE WELL

Figure 4. Location of Huron Project observation wells, test holes, and recharge well within the study area. 


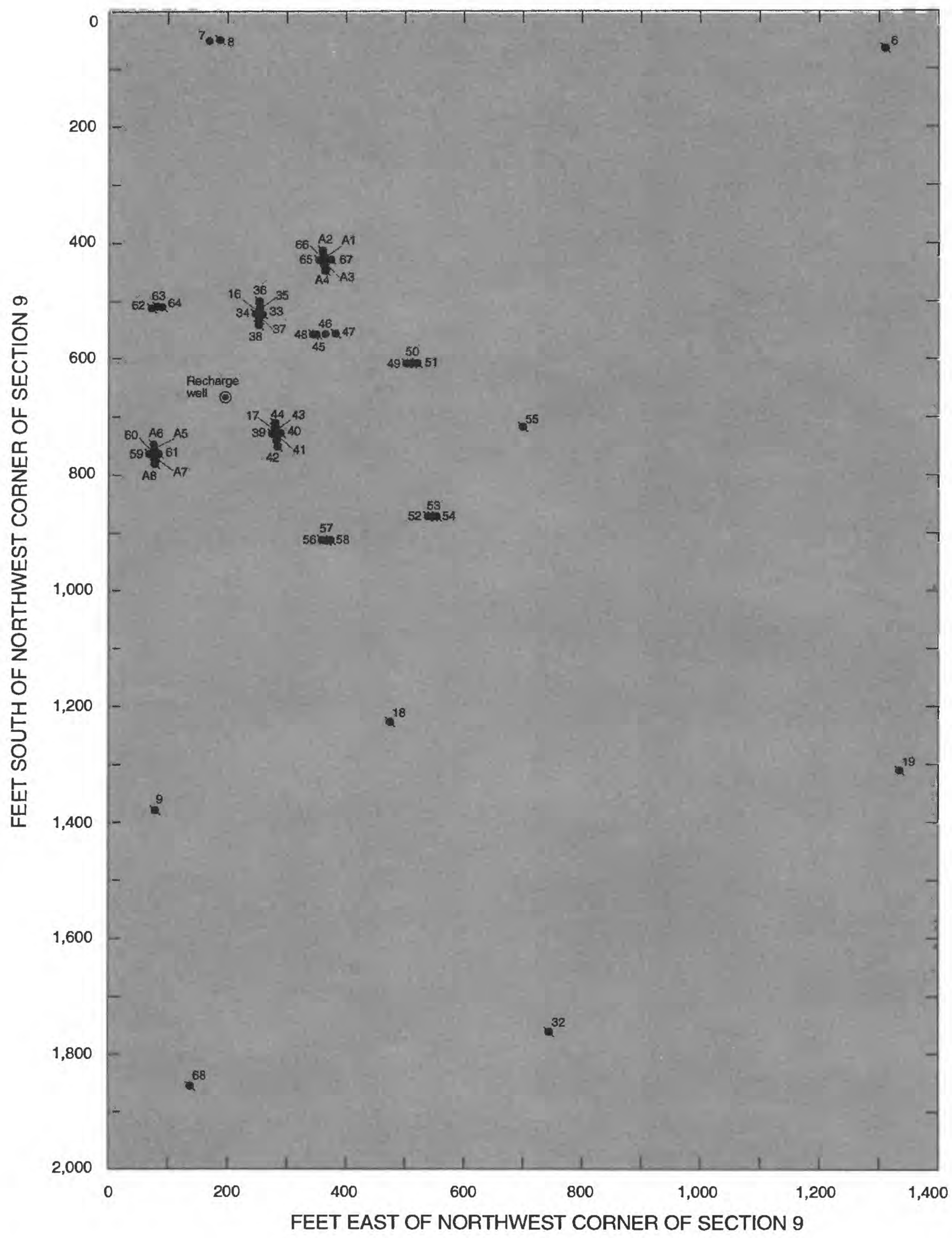

Figure 4. Location of Huron Project observation wells, test holes, and recharge well within the study area.--Continued 
Table 3. Selected site data for Huron Project observation wells, test holes, and recharge well [Other identifier: $\mathrm{CO}$, combination rig; A, auger rig. All values given in feet below or above $(-)$ land surface. --, no data]

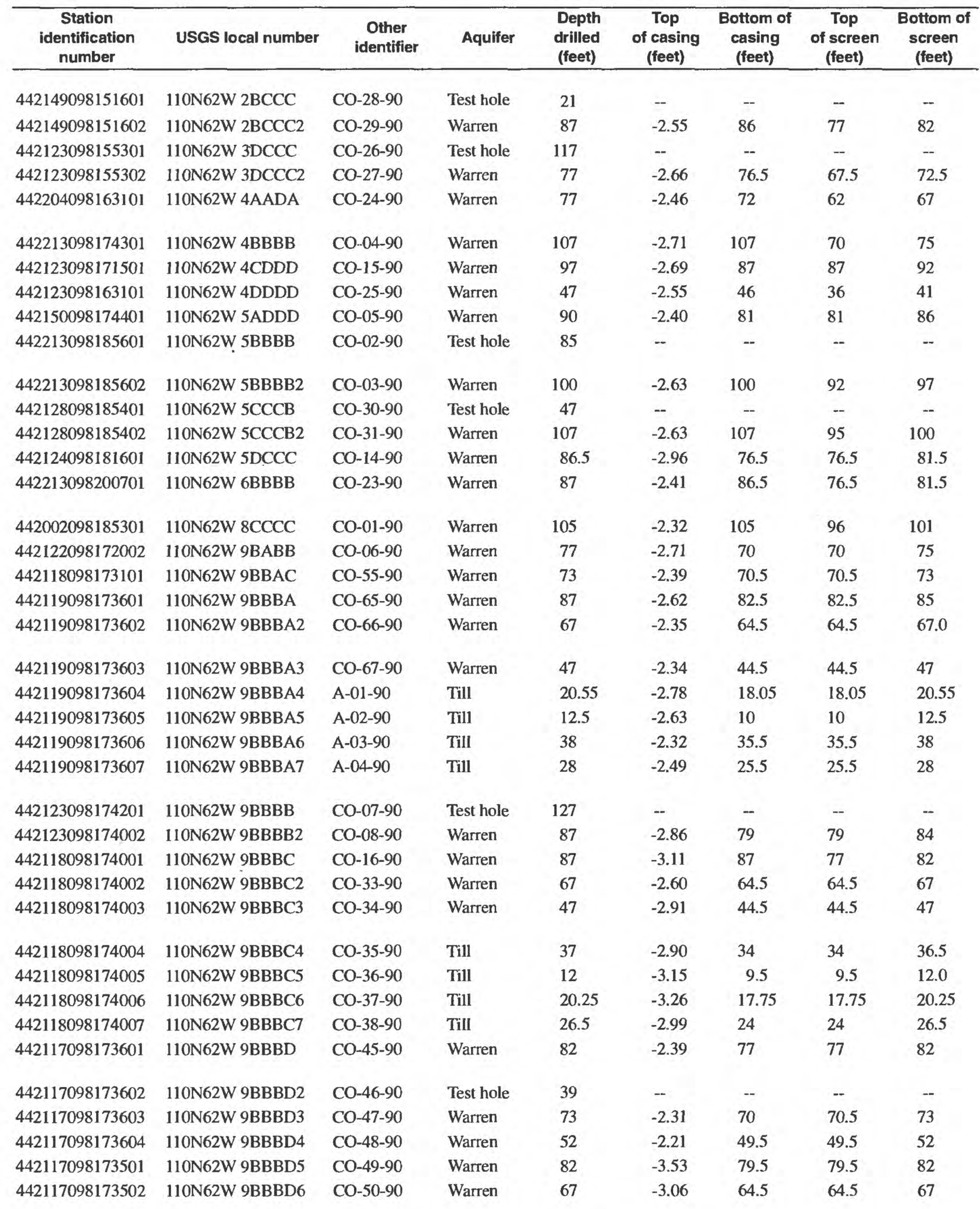


Table 3. Selected site data for Huron Project observation wells, test holes, and recharge well—Continued

\begin{tabular}{|c|c|c|c|c|c|c|c|c|}
\hline $\begin{array}{c}\text { Station } \\
\begin{array}{c}\text { identification } \\
\text { number }\end{array} \\
\end{array}$ & USGS local number & $\begin{array}{c}\text { Other } \\
\text { identifier }\end{array}$ & Aquifer & $\begin{array}{l}\text { Depth } \\
\text { drilled } \\
\text { (feet) }\end{array}$ & $\begin{array}{c}\text { Top } \\
\text { of casing } \\
\text { (feet) }\end{array}$ & $\begin{array}{c}\text { Bottom of } \\
\text { casing } \\
\text { (feet) }\end{array}$ & $\begin{array}{c}\text { Top } \\
\text { of screen } \\
\text { (feet) }\end{array}$ & $\begin{array}{c}\text { Bottom of } \\
\text { screen } \\
\text { (feet) }\end{array}$ \\
\hline 442117098173503 & 110N62W 9BBBD7 & CO-51-90 & Warren & 47 & -2.98 & 44.5 & 44.5 & 47 \\
\hline 442115098173501 & $110 \mathrm{~N} 62 \mathrm{~W} 9 \mathrm{BBCA}$ & $\mathrm{CO}-52-90$ & Warren & 72 & -2.90 & 60 & 60 & 62.5 \\
\hline 442115098173502 & $110 \mathrm{~N} 62 \mathrm{~W} 9 \mathrm{BBCA} 2$ & CO-53-90 & Warren & 74 & -2.34 & 71 & 71.5 & 74 \\
\hline 442115098173503 & $110 \mathrm{~N} 62 \mathrm{~W} 9 \mathrm{BBCA} 3$ & CO-54-90 & Warren & 47 & -2.55 & 44.5 & 44.5 & 47 \\
\hline 442111098173801 & $110 \mathrm{~N} 62 \mathrm{~W} 9 \mathrm{BBCB}$ & CO-18-90 & Warren & 81 & -2.71 & 51 & 46 & 51 \\
\hline 442117098174002 & $110 \mathrm{~N} 62 \mathrm{~W} 9 \mathrm{BBCB} 2$ & CO-39-90 & Warren & 56.5 & -3.32 & 54 & 54 & 56.5 \\
\hline 442117098174003 & $110 \mathrm{~N} 62 \mathrm{~W} 9 \mathrm{BBCB} 3$ & $\mathrm{CO}-40-90$ & Warren & 67 & -2.69 & 63.25 & 63.25 & 65.75 \\
\hline 442117098174004 & $110 \mathrm{~N} 62 \mathrm{~W} 9 \mathrm{BBCB} 4$ & CO-41-90 & Till & 47 & -2.67 & 44.5 & 44.5 & 47 \\
\hline 442117098174005 & $110 \mathrm{~N} 62 \mathrm{~W} 9 \mathrm{BBCB} 5$ & $\mathrm{CO}-42-90$ & Till & 27 & -2.59 & 24.5 & 24.5 & 27 \\
\hline 442117098174006 & $110 \mathrm{~N} 62 \mathrm{~W} 9 \mathrm{BBCB} 6$ & $\mathrm{CO}-43-90$ & Till & 12 & -3.32 & 9.5 & 9.5 & 12 \\
\hline 442117098174007 & $110 \mathrm{~N} 62 \mathrm{~W} 9 \mathrm{BBCB} 7$ & $\mathrm{CO}-44-90$ & Till & 22 & -2.91 & 19.5 & 19.5 & 22 \\
\hline 442117098174001 & $110 \mathrm{~N} 62 \mathrm{~W} 9 \mathrm{BBCB} 8$ & $\mathrm{CO}-17-90$ & Warren & 84 & -2.81 & 70 & 70 & 75 \\
\hline 442115098174202 & $110 \mathrm{~N} 62 \mathrm{~W} 9 \mathrm{BBCB} 9$ & CO-63-90 & Warren & 67 & -2.81 & 64.5 & 64.5 & 67 \\
\hline 442115098174203 & $110 \mathrm{~N} 62 \mathrm{~W} 9 \mathrm{BBCB} 10$ & CO-64-90 & Warren & 47 & -2.44 & 44.5 & 44.5 & 47 \\
\hline 442115098174201 & $110 \mathrm{~N} 62 \mathrm{~W}$ 9BBCB11 & $\mathrm{CO}-62-90$ & Warren & 87 & -3.11 & 82 & 82 & 87 \\
\hline 442115098173902 & $110 \mathrm{~N} 62 \mathrm{~W} 9 \mathrm{BBCB} 12$ & CO-57-90 & Warren & 60 & -2.60 & 57.5 & 57.5 & 60 \\
\hline 442115098173903 & $110 \mathrm{~N} 62 \mathrm{~W} 9 \mathrm{BBCB} 13$ & CO-58-90 & Warren & 47 & -2.58 & 40.35 & 40.35 & 42.85 \\
\hline 442115098173901 & $110 \mathrm{~N} 62 \mathrm{~W} 9 \mathrm{BBCB} 14$ & CO-56-90 & Warren & 81 & -2.59 & 75.5 & 75.5 & 78 \\
\hline 442117098174008 & $110 \mathrm{~N} 62 \mathrm{~W} 9 \mathrm{BBCB} 15$ & Recharge well & Warren & 80 & -1.56 & 60 & 60 & 80 \\
\hline 442113098174201 & $110 \mathrm{~N} 62 \mathrm{~W} 9 \mathrm{BBCC}$ & CO-59-90 & Warren & 81 & -2.85 & 78 & 78.5 & 81 \\
\hline 442113098174202 & $110 \mathrm{~N} 62 \mathrm{~W} 9 \mathrm{BBCC} 2$ & $\mathrm{CO}-60-90$ & Warren & 67 & -2.79 & 64.5 & 64.5 & 67 \\
\hline 442113098174203 & $110 \mathrm{~N} 62 \mathrm{~W} 9 \mathrm{BBCC} 3$ & CO-61-90 & Warren & 47 & -2.60 & 44.5 & 44.5 & 47 \\
\hline 442113098174204 & $110 \mathrm{~N} 62 \mathrm{~W} 9 \mathrm{BBCC} 4$ & A-05-90 & Till & 23 & -2.27 & 20 & 20.5 & 23 \\
\hline 442113098174205 & $110 \mathrm{~N} 62 \mathrm{~W} 9 \mathrm{BBCC} 5$ & A- $-06-90$ & Till & 13 & -3.26 & 8.5 & 8.5 & 11 \\
\hline 442113098174206 & $110 \mathrm{~N} 62 \mathrm{~W} 9 \mathrm{BBCC} 6$ & A- $07-90$ & Till & 43 & -2.28 & 37.5 & 37.5 & 40 \\
\hline 442113098174207 & $110 \mathrm{~N} 62 \mathrm{~W} 9 \mathrm{BBCC} 7$ & A- $08-90$ & Till & 33 & -2.38 & 30.5 & 30.5 & 33 \\
\hline 442110098174201 & $110 \mathrm{~N} 62 \mathrm{~W} 9 \mathrm{BBCC} 8$ & $\mathrm{CO}-09-90$ & Warren & 73 & -2.47 & 65 & 65 & 70 \\
\hline 442110098172501 & $110 \mathrm{~N} 62 \mathrm{~W} 9 \mathrm{BBDD}$ & CO-19-90 & Warren & 77 & -2.57 & 72 & 72 & 77 \\
\hline 442108098173101 & $110 \mathrm{~N} 62 \mathrm{~W} 9 \mathrm{BCAB}$ & $\mathrm{CO}-32-90$ & Warren & 87 & -2.80 & 87 & 79 & 84 \\
\hline 442105098174001 & $110 \mathrm{~N} 62 \mathrm{~W} 9 \mathrm{BCBC}$ & $\mathrm{CO}-68-90$ & Warren & 94 & -2.83 & 94 & 85 & 90 \\
\hline 442057098172501 & $110 \mathrm{~N} 62 \mathrm{~W} 9 \mathrm{BCDD}$ & CO-10-90 & Warren & 77 & -2.70 & 59 & 59 & 64 \\
\hline 442002098162801 & $110 \mathrm{~N} 62 \mathrm{~W} 10 \mathrm{CCCC}$ & CO-11-90 & Warren & 71 & -2.83 & 71 & 62 & 67 \\
\hline 442031098151801 & 110N62W10DDDD & $\mathrm{CO}-12-90$ & Warren & 77 & -2.68 & 67 & 67 & 72 \\
\hline 442032098172501 & 110N62W16BBAA & CO-13-90 & Warren & 81 & -2.96 & 68 & 68 & 73 \\
\hline 441937098163001 & $110 \mathrm{~N} 62 \mathrm{~W} 21 \mathrm{AAAA}$ & CO-21-90 & Warren & 77 & -2.43 & 71.5 & 71.5 & 76.5 \\
\hline 441937098174001 & $110 \mathrm{~N} 62 \mathrm{~W} 21 \mathrm{BBBB}$ & $\mathrm{CO}-20-90$ & Warren & 92.5 & -2.54 & 92.5 & 82.5 & 87.5 \\
\hline 441937098151701 & $110 \mathrm{~N} 62 \mathrm{~W} 22 \mathrm{AAAA}$ & CO-22-90 & Warren & 57 & -3.06 & 56 & 46 & 51 \\
\hline
\end{tabular}




\section{WATER-LEVEL DATA}

Water-level data are presented for 15 DENR observation wells, 70 Huron Project observation wells, and the recharge well within the study area. The locations of the wells are shown in figure 3 (DENR wells) and figure 4 (Huron Project wells). USGS personnel have been responsible for the maintenance of both the DENR and Huron Project observation wells and for the collection and compilation of the water-level records.

The following section of this report presents a site description and hydrograph for each observation well. Hydrographs for DENR observation wells are presented in figures 5-19. Hydrographs for Huron Project observation wells and the recharge well are presented in figures 20-90. The period of record shown for both the DENR and Huron Project observation wells is from October 1, 1993, through November 29, 1995. Hydrographs for the period from the earliest available record through September 30, 1993, are presented in Carter (1995). The existing DENR wells and Huron Project wells were measured bimonthly beginning in 1990, and monthly beginning in 1994. A negative water level indicates a water level above land surface. The data used to generate the hydrographs are available in the USGS's "Ground Water Site Inventory" (GWSI) data base.
Water levels within wells can be affected by several factors. Pumping of nearby wells can cause short-term and long-term declines in water levels. The observation wells completed in the Warren aquifer that are located in or near the well field are affected by the annual pumping of the city production wells from October 1 to April 1. These wells also were affected by the four 3-day aquifer tests conducted at the recharge well during the spring and fall of 1994 and 1995 and by the injection of recharge water during the summers of 1994 and 1995. The water-level decline for these wells during the production period and aquifer tests can be seen on their corresponding hydrographs. The waterlevel increase for these wells during the injection period also can be seen on their corresponding hydrographs. Other wells in the study area can be affected by pumping if they are located near irrigation wells.

Short-term changes in water levels in artesian aquifers also can be caused by fluctuations in barometric pressure. Long-term increases and decreases in water levels generally correspond to changes in the recharge and discharge rates of the aquifer. Generally, increases in water levels correspond to periods of wet climatic conditions when aquifer recharge exceeds discharge. Long-term declines in water levels generally reflect periods of drought or increases in ground-water consumption when aquifer discharge exceeds recharge. 
LOCAL WELL NUMBER: 110N61W19AAAA

SITE ID: 441935098114101

OTHER IDENTIFIER: BD-60H

ALTITUDE OF LAND SURFACE: 1,239 feet

MEASURING POINT: 2.00 feet above land surface

AQUIFER: Warren

PERIOD OF RECORD: May 24, 1982, to November 29, 1995

EXTREMES FOR PERIOD SHOWN: Highest, 2.88 feet, April 27, 1995; lowest, 13.68 feet, November 29, 1994.

EXTREMES FOR PERIOD OF RECORD: Highest, 2.88 feet, April 27, 1995; lowest, 13.68 feet, November 29, 1994.
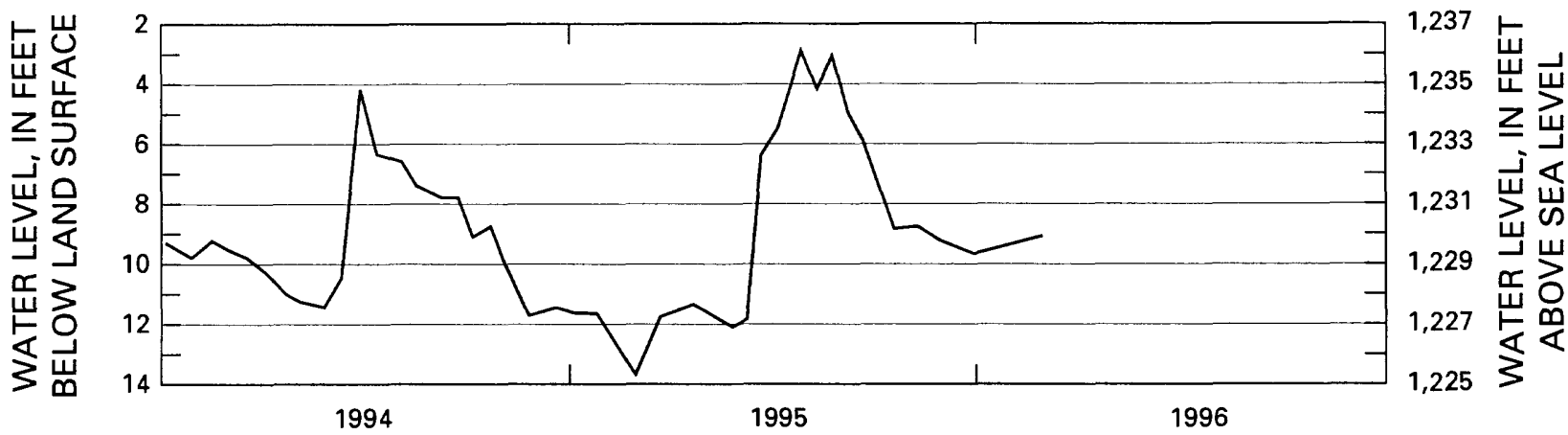

WATER YEAR

Figure 5. Hydrograph for observation well 110N61W19AAAA, BD-60H, water years 1994-96.

LOCAL WELL' NUMBER: 110N62W7BBBB

SITE ID: 442119098200701

OTHER IDENTIFIER: BD-76I

ALTITUDE OF LAND SURFACE: 1,326 feet

MEASURING POINT: 1.30 feet above land surface

AQUIFER: Pleistocene Series

PERIOD OF RECORD: December 1, 1976, to November 29, 1995

EXTREMES FOR PERIOD SHOWN: Highest, 35.37 feet, November 29, 1995; lowest, 50.10 feet, October 29, 1993.

EXTEMES FOR PERIOD OF RECORD: Highest, 35.37 feet, November 29, 1995; lowest, 51.83 feet, April 1, 1991.
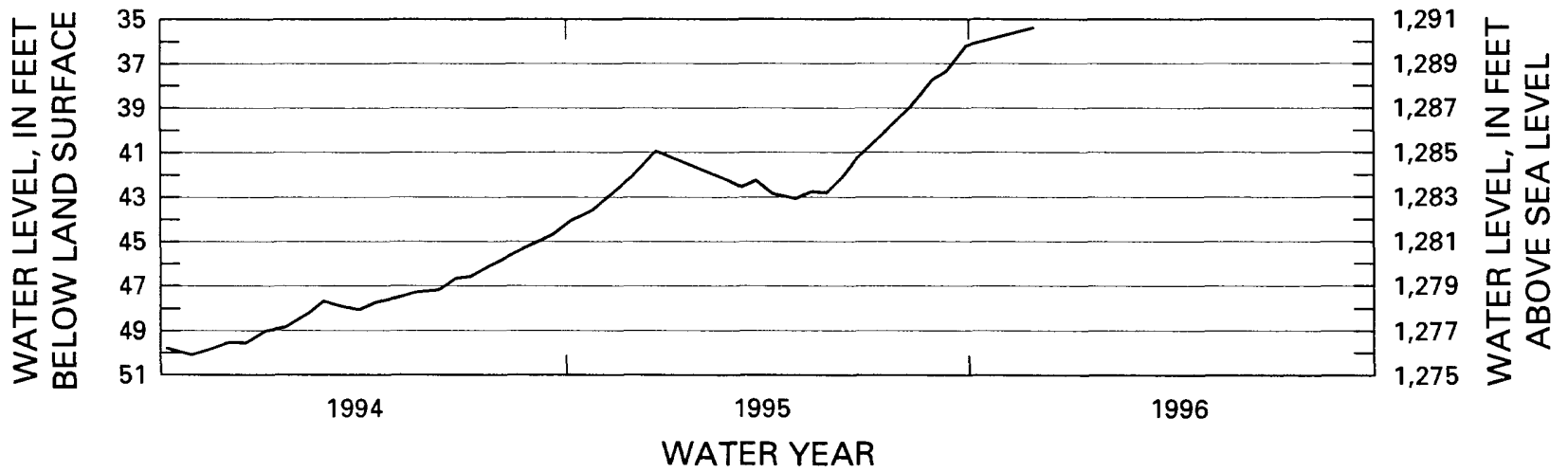

Figure 6. Hydrograph for observation well 110N62W7BBBB, BD-76I, water years 1994-96. 
LOCAL WELL NUMBER: 110N62W9CCCC

SITE ID: 442033098174001

OTHER IDENTIFIER: BD-76K

ALTITUDE OF LAND SURFACE: 1,300 feet

MEASURING POINT: 1.50 feet above land surface

AQUIFER: Warren

PERIOD OF RECORD: October 8, 1976, to November 29, 1995

EXTREMES FOR PERIOD SHOWN: Highest, 20.71 feet, August 29, 1995; lowest, 53.42 feet, March 11, 1994. EXTREMES FOR PERIOD OF RECORD: Highest, 20.71 feet, August 29, 1995; lowest, 59.52 feet, April 2, 1990.

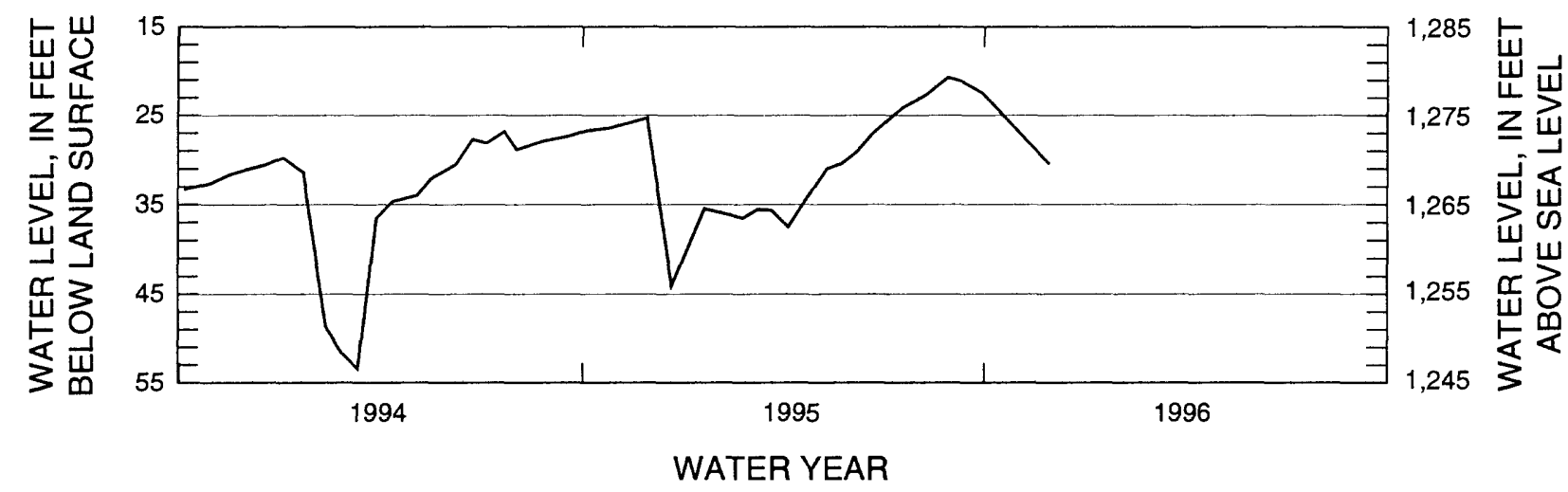

Figure 7. Hydrograph for observation well 110N62W9CCCC, BD-76K, water years 1994-96.

LOCAL WELL NUMBER: 110N62W16DCCC

SITE ID: 441941098170301

OTHER IDENTIFIER: BD-60F

ALTITUDE OF LAND SURFACE: $1,311.9$ feet

MEASURING POINT: 1.50 feet above land surface

AQUIFER: Warren

PERIOD OF RECORD: June 23, 1960, to November 29, 1995

EXTREMES FOR PERIOD SHOWN: Highest, 26.42 feet, September 29, 1995; lowest, 41.41 feet, March 28, 1994.

EXTREMES FOR PERIOD OF RECORD: Highest, 18.60 feet, March 4, 1963; lowest, 52.53 feet, March 21, 1990.
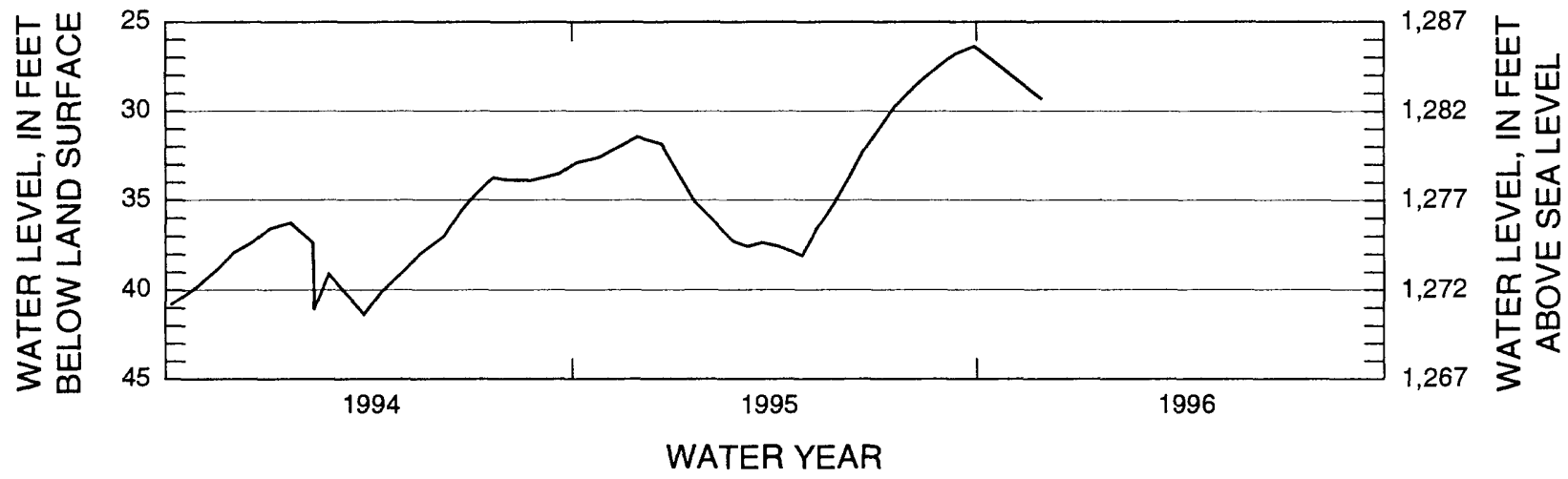

Figure 8. Hydrograph for observation well 110N62W16DCCC, BD-60F, water years 1994-96. 
LOCAL WELL NUMBER: 110N62W18BBBB

SITE ID: 442027098200701

OTHER IDENTIFIER: BDS-54-78

ALTITUDE OF LAND SURFACE: 1,305 feet

MEASURING POINT: 2.50 feet above land surface

AQUIFER: Unknown

PERIOD OF RECORD: March 21, 1990, to November 29, 1995

EXTREMES FOR PERIOD SHOWN: Highest, 0.14 feet, March 11, 1994; lowest, 3.91 feet, August $29,1995$. EXTREMES FOR PERIOD OF RECORD: Highest, -0.22 feet, June 6, 1991; lowest, 6.57 feet, February 20, 1991.
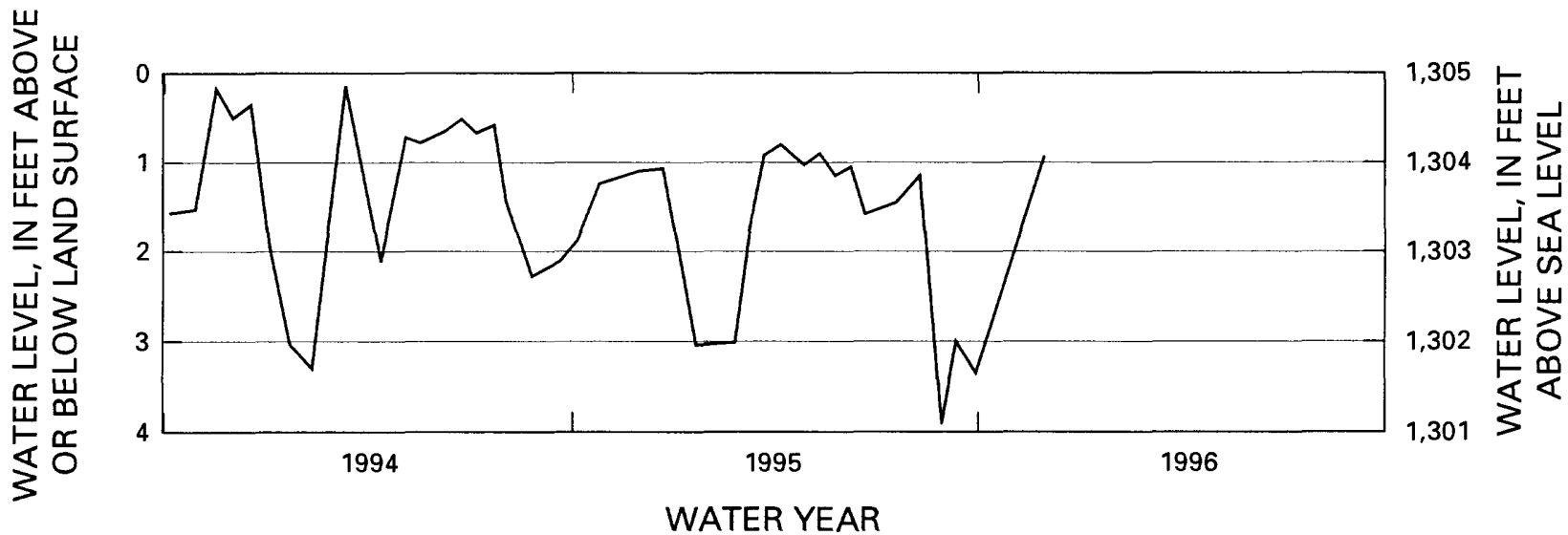

WATER YEAR

Figure 9. Hydrograph for observation well 110N62W18BBBB, BDS-54-78, water years 1994-96.

LOCAL WELL NUMBER: 110N62W19AAAA2

SITE ID: 441935098185702

OTHER IDENTIFIER: BD-82A

ALTITUDE OF LAND SURFACE: 1,305 feet

MEASURING POINT: 2.20 feet above land surface

AQUIFER: Warren

PERIOD OF RECORD: October 8, 1976, to November 29, 1995

EXTREMES FOR PERIOD SHOWN: Highest, 16.47 feet, September 29, 1995; lowest, 32.24 feet, March 11, 1994.

EXTREMES FOR PERIOD OF RECORD: Highest, 16.47, September 29, 1995; lowest, 53.3, August 15, 1980.

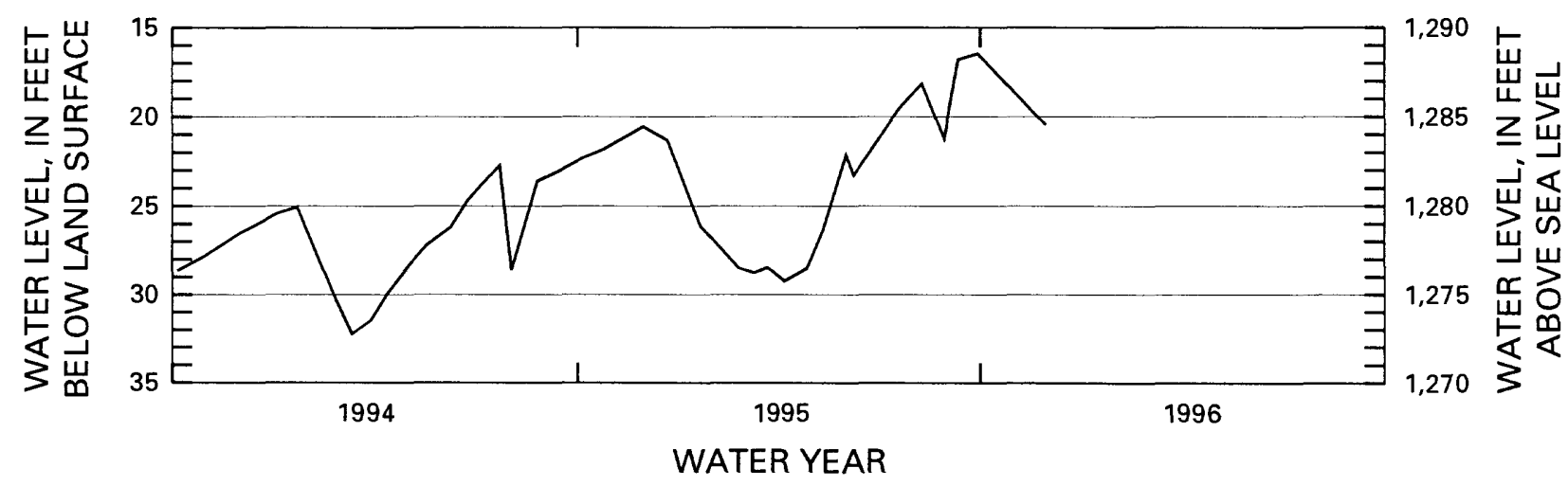

Figure 10. Hydrograph for observation well 110N62W19AAAA2, BD-82A, water years 1994-96. 
LOCAL WELL NUMBER: 110N62W25CCCC

SITE ID: 441757098135901

OTHER IDENTIFIER: BD-76L

ALTITUDE OF LAND SURFACE: 1,305 feet

MEASURING POINT: 0.20 foot above land surface

AQUIFER: Pleistocene Series

PERIOD OF RECORD: December 1, 1976, to November 29, 1995

EXTREMES FOR PERIOD SHOWN: Highest, 23.74 feet, November 29, 1995; lowest, 39.75 feet, August 25, 1994.

EXTREMES FOR PERIOD OF RECORD: Highest, 23.74 feet, November 29, 1995; lowest, 46.3 feet, July 28, 1981.

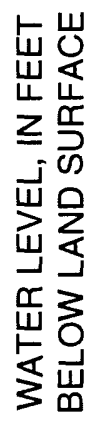
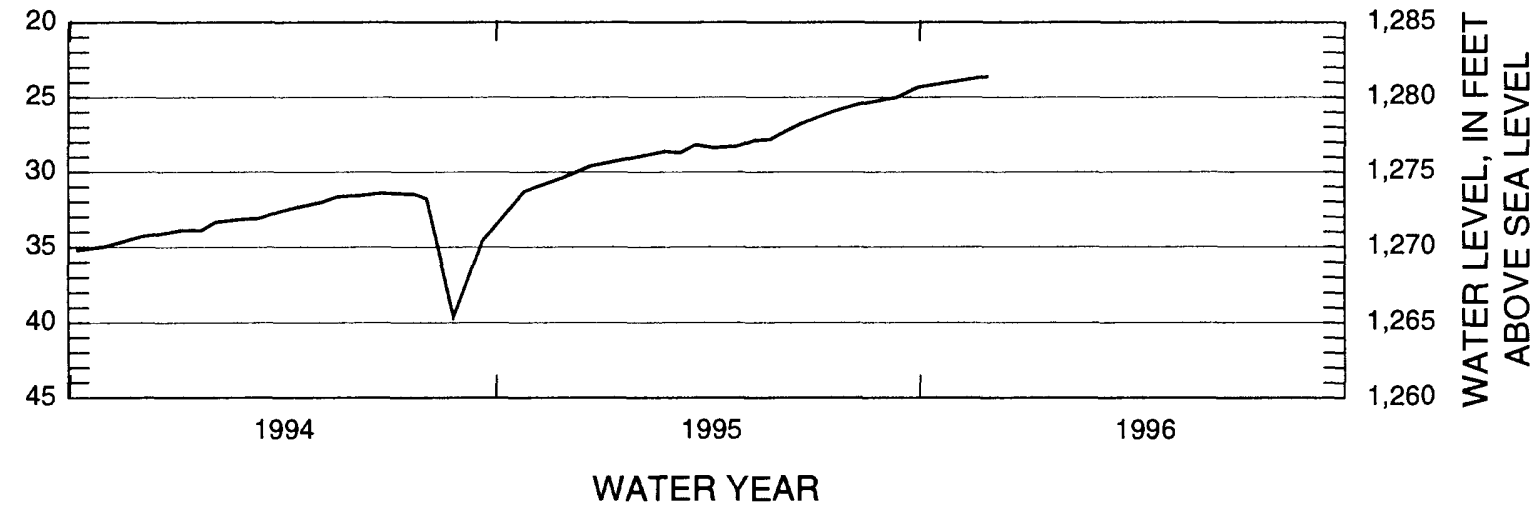

WATER YEAR

Figure 11. Hydrograph for observation well 110N62W25CCCC, BD-76L, water years 1994-96.

LOCAL WELL NUMBER: 111N62W32AADD

SITE ID: 452254097174501

OTHER IDENTIFIER: BD-79C

ALTITUDE OF LAND SURFACE: 1,309 feet

MEASURING POINT: 2.90 feet above land surface

AQUIFER: Warren

PERIOD OF RECORD: June 26, 1979, to November 29, 1995

EXTREMES FOR PERIOD SHOWN: Highest, 14.53 feet, September 11, 1995; lowest, 26.10 feet, March 11, 1994.

EXTREMES FOR PERIOD OF RECORD: Highest, 14.53 feet, September 11, 1995; lowest, 48.00 feet, August 18, 1988, September 22, 1989.
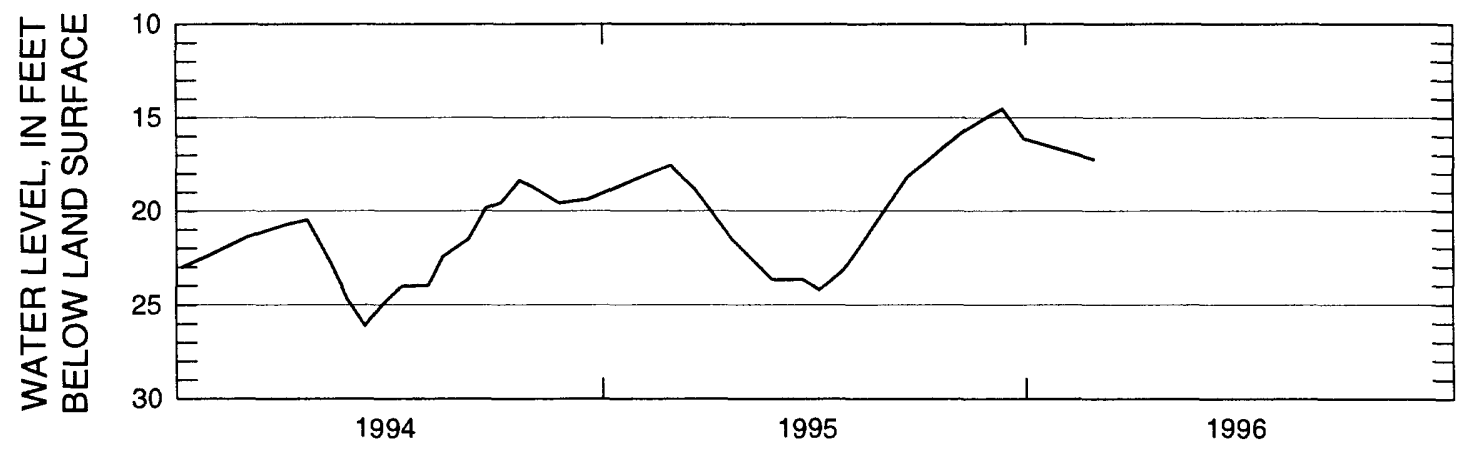

1994

1995

1996

WATER YEAR

Figure 12. Hydrograph for observation well 111N62W32AADD, BD-79C, water years 1994-96. 
LOCAL WELL NUMBER: 111N62W32ADAA

SITE ID: 442250098174401

OTHER IDENTIFIER: BD-60D

ALTITUDE OF LAND SURFACE: $1,304.51$ feet

MEASURING POINT: 2.00 feet above land surface

AQUIFER: Pleistocene Series

PERIOD OF RECORD: June 21, 1960, to November 29, 1995

EXTREMES FOR PERIOD SHOWN: Highest, 0.58 feet, May 11, 1995; lowest, 8.21 feet, February 24, 1995.

EXTREMES FOR PERIOD OF RECORD: Highest, 0.58 feet, May 11, 1995; lowest, 42.40 feet, August 23,

1976.
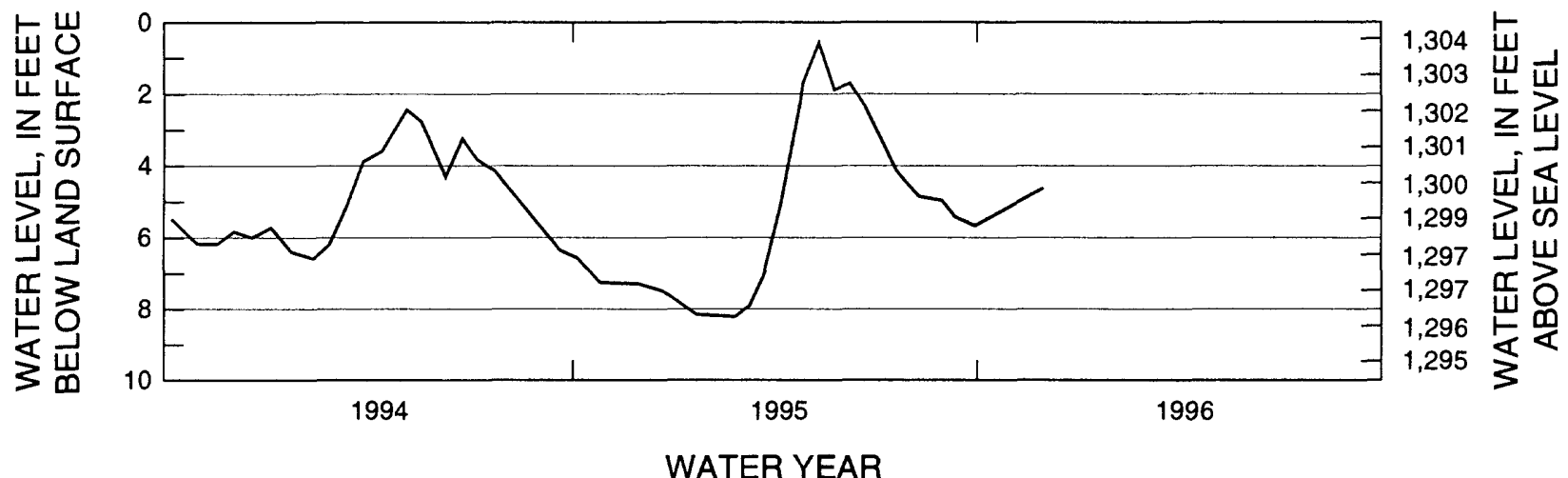

WATER YEAR

Figure 13. Hydrograph for obsenvation well 111N62W32ADAA, BD-60D, water years 1994-96.

LOCAL WELL NUMBER: 111N63W2CCCC

SITE ID: 442638098223301

OTHER IDENTIFIER: BD-60A

ALTITUDE OF LAND SURFACE: $1,327.86$ feet

MEASURING POINT: 0.98 foot above land surface

AQUIFER: Pleistocene Series

PERIOD OF RECORD: June 16, 1960, to November 29, 1995

EXTREMES FOR PERIOD SHOWN: Highest, 19.99 feet, November 29, 1995; lowest, 29.29 feet,

September 11, 1995.

EXTREMES FOR PERIOD OF RECORD: Highest, 12.20 feet, October 29, 1962; lowest, 43.50 feet, July 22, 1981.
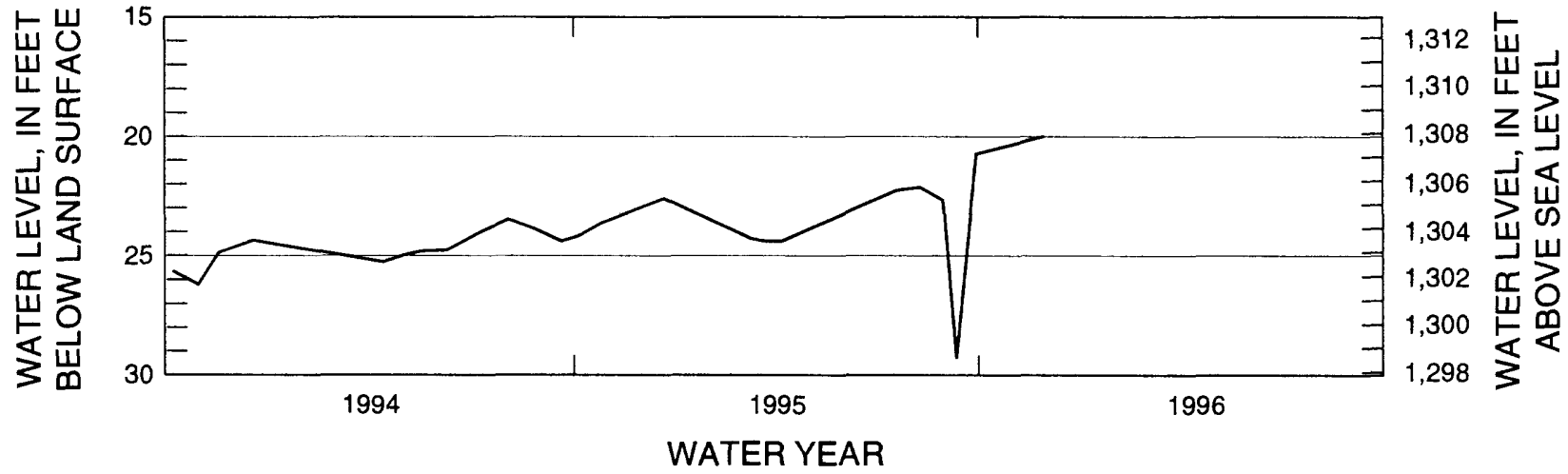

Figure 14. Hydrograph for observation well 111N63W2CCCC, BD-60A, water years 1994-96. 
LOCAL WELL NUMBER: 111N63W9BBBB

SITE ID: 442632098250001

OTHER IDENTIFIER: BD-76C

ALTITUDE OF LAND SURFACE: 1,342 feet

MEASURING POINT: 2.39 feet above land surface

AQUIFER: Pleistocene Series

PERIOD OF RECORD: December 1, 1976, to November 29, 1995

EXTREMES FOR PERIOD SHOWN: Highest, 27.07 feet, November 29, 1995; lowest, 39.73 feet, August 25, 1994.

EXTREMES FOR PERIOD OF RECORD: Highest, 27.07 feet, November 29, 1995; lowest, 53.70 feet, August 17, 1989.
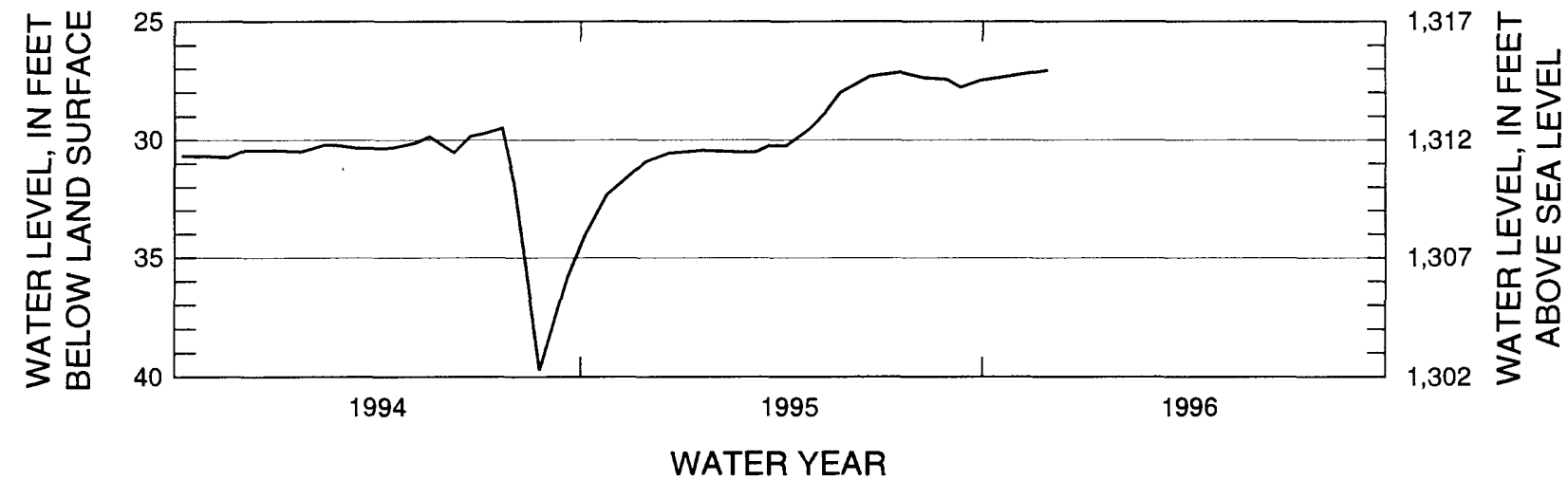

Figure 15. Hydrograph for observation well 111N63W9BBBB, BD-76C, water years 1994-96.

LOCAL WELL NUMBER: 111N63W12AAAA

SITE ID: 442633098201101

OTHER IDENTIFIER: BD-79A

ALTITUDE OF LAND SURFACE: 1,316 feet

MEASURING POINT: 3.15 feet above land surface

AQUIFER: Warren

PERIOD OF RECORD: June 4, 1979, to November 29, 1995

EXTREMES FOR PERIOD SHOWN: Highest, 13.24 feet, November 29, 1995; lowest, 19.04 feet, October 6, 1993.

EXTREMES FOR PERIOD OF RECORD: Highest, 13.24 feet, November 29, 1995; lowest, 41.40 feet, August 24, 1981.
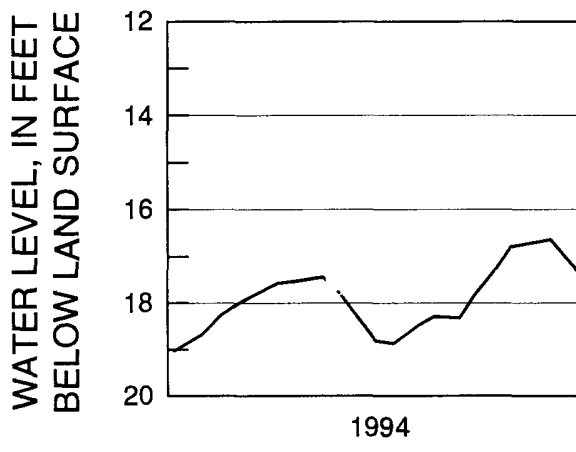

1994

Figure 16. Hydrograph for observation well 111N63W12AAAA, BD-79A, water years 1994-96. 
LOCAL WELL NUMBER: 111N63W14CCCC

SITE ID: 442451098151501

OTHER IDENTIFIER: BD-79B

ALTITUDE OF LAND SURFACE: 1,322 feet

MEASURING POINT: 2.66 feet above land surface

AQUIFER: Warren

PERIOD OF RECORD: June 5, 1979, to November 29, 1995

EXTREMES FOR PERIOD SHOWN: Highest, 16.52 feet, November 29, 1995; lowest, 24.12 feet, August 25, 1994.

EXTREMES FOR PERIOD OF RECORD: Highest, 16.52 feet, November 29, 1995; lowest, 46.40 feet, August 17, 1989.
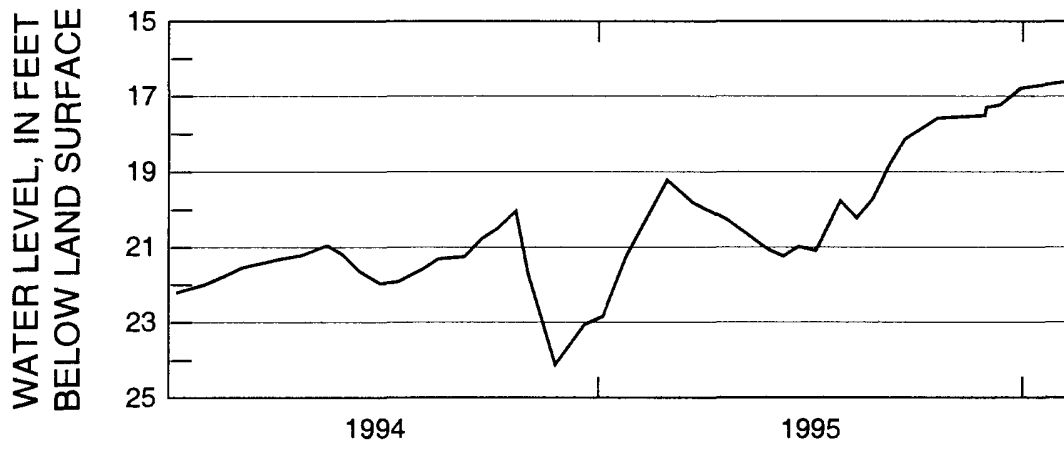

WATER YEAR

Figure 17. Hydrograph for observation well 111N63W14CCCC, BD-79B, water years 1994-96.

LOCAL WELL NUMBER: 111N63W24DDDD

SITE ID: 442402098201101

OTHER IDENTIFIER: BD-60C

ALTITUDE OF LAND SURFACE: $1,312.24$ feet

MEASURING POINT: 2.00 feet above land surface

AQUIFER: Pleistocene Series

PERIOD OF RECORD: June 20, 1960, to November 29, 1995

EXTREMES FOR PERIOD SHOWN: Highest, 17.18 feet, November 29, 1995; lowest, 25.11 feet, March 28, 1994.

EXTREMES FOR PERIOD OF RECORD: Highest, 14.60 feet, March 4, 1963; lowest, 47.70 feet, July $27,1981$.
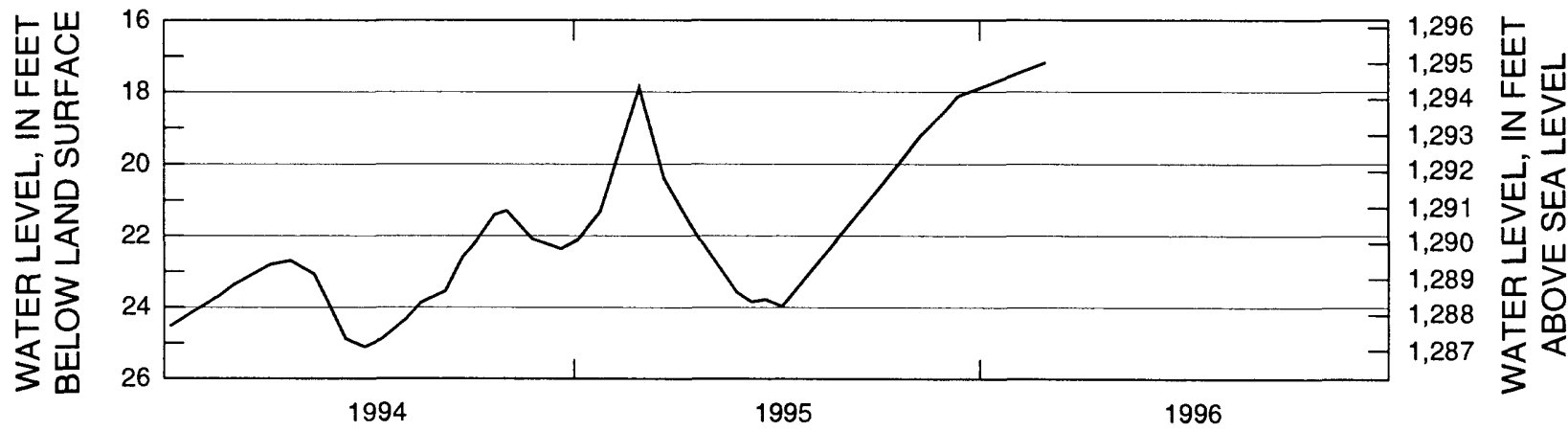

WATER YEAR

Figure 18. Hydrograph for observation well 111N63W24DDDD, BD-60C, water years 1994-96. 
LOCAL WELL NUMBER: 112N63W36BBBB

SITE ID: 442816098212001

OTHER IDENTIFIER: BD-76B

ALTITUDE OF LAND SURFACE: 1,308 feet

MEASURING POINT: 2.09 feet above land surface

AQUIFER: Pleistocene Series

PERIOD OF RECORD: October 22, 1976, to November 29, 1995

EXTREMES FOR PERIOD SHOWN: Highest, 7.46 feet, November 29, 1995; lowest, 11.66 feet, October 6, 1993.

EXTREMES FOR PERIOD OF RECORD: Highest, 7.46 feet, November 29, 1995; lowest, 22.40 feet, September 15, 1981.
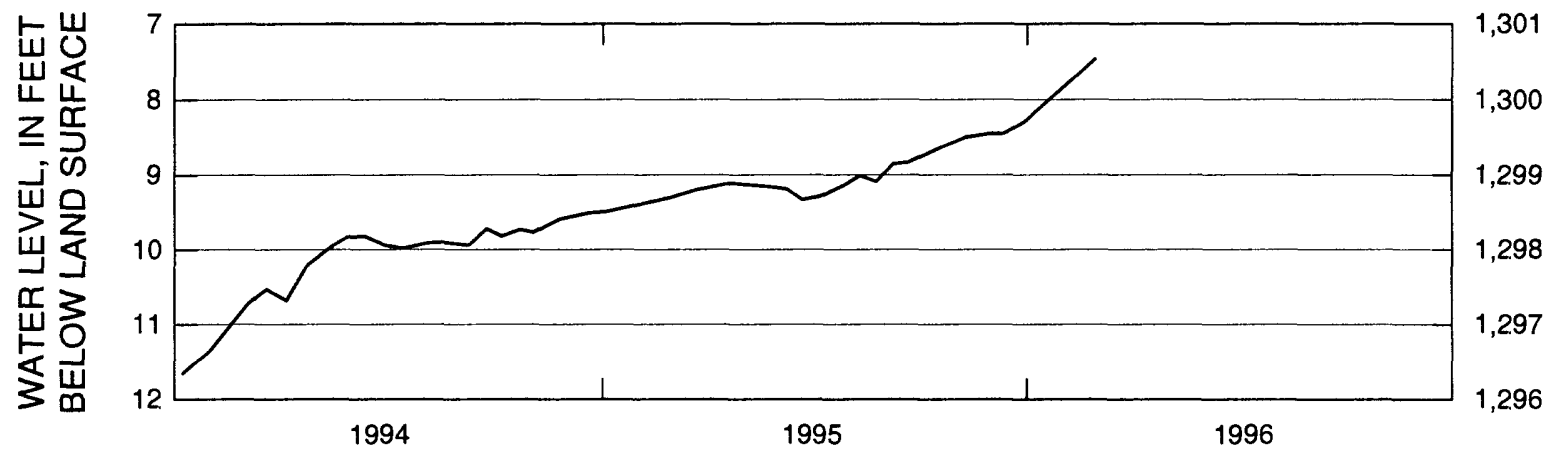

994

1995

WATER YEAR

Figure 19. Hydrograph for observation well 112N63W36BBBB, BD-76B, water years 1994-96. 
LOCAL WELL NUMBER: 110N62W2BCCC2

SITE IDENTIFIER: 442149098151602

OTHER IDENTIFIER: CO-29-90

ALTITUDE OF LAND SURFACE: $1,284.20$ feet

MEASURING POINT: 2.55 feet above land surface

AQUIFER: Warren

PERIOD OF RECORD: November 6, 1990, to November 29, 1995

EXTREMES FOR PERIOD SHOWN: Highest, 3.87 feet, June 21, 1995; lowest, 7.55 feet, February 27, 1995 , March 9, 1995.

EXTREMES FOR PERIOD OF RECORD: Highest, 3.87 feet, June 21, 1995; lowest, 11.81 feet, April 15, 1991.
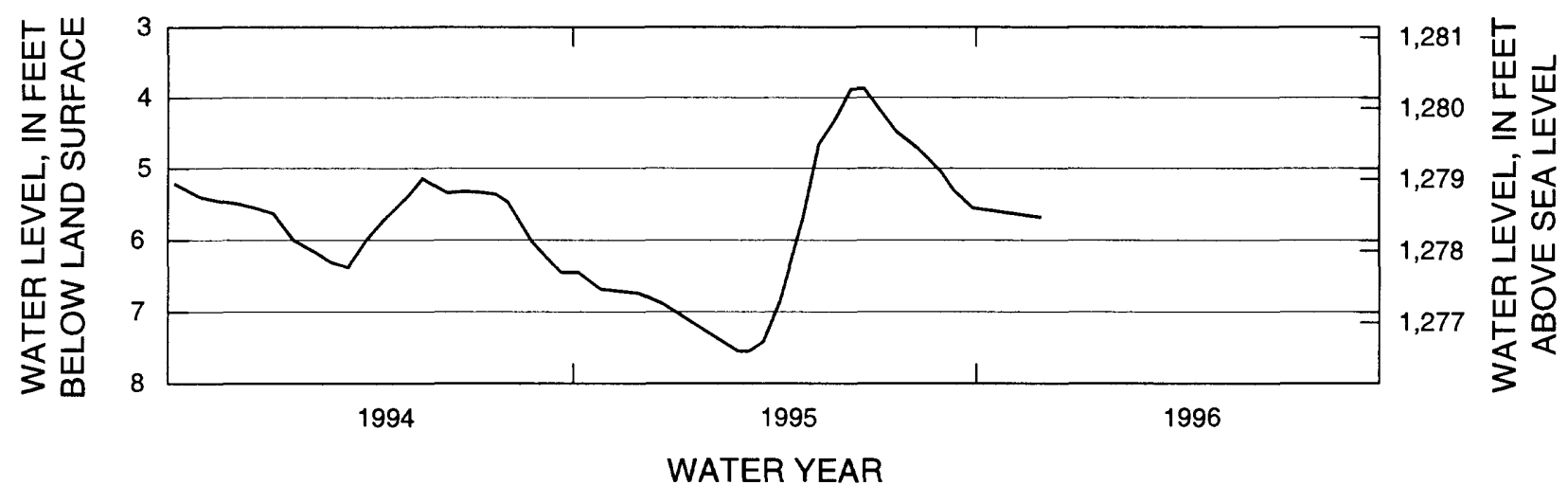

WATER YEAR

Figure 20. Hydrograph for observation well 110N62W2BCCC2, CO-29-90, water years 1994-96.

LOCAL WELL NUMBER: 110N62W3DCCC2

SITE IDENTIFIER: 442123098155302

OTHER IDENTIFIER: CO-27-90

ALTITUDE OF LAND SURFACE: $1,287.70$ feet

MEASURING POINT: 2.66 feet above land surface

AQUIFER: Warren

PERIOD OF RECORD: November 6, 1990, to November 29, 1995

EXTREMES FOR PERIOD SHOWN: Highest, 3.16 feet, November 29, 1995; lowest, 5.76 feet, February 27 , 1995.

EXTREMES FOR PERIOD OF RECORD: Highest, 3.16 feet, November 29, 1995; lowest, 13.08 feet, July 9, 1991.
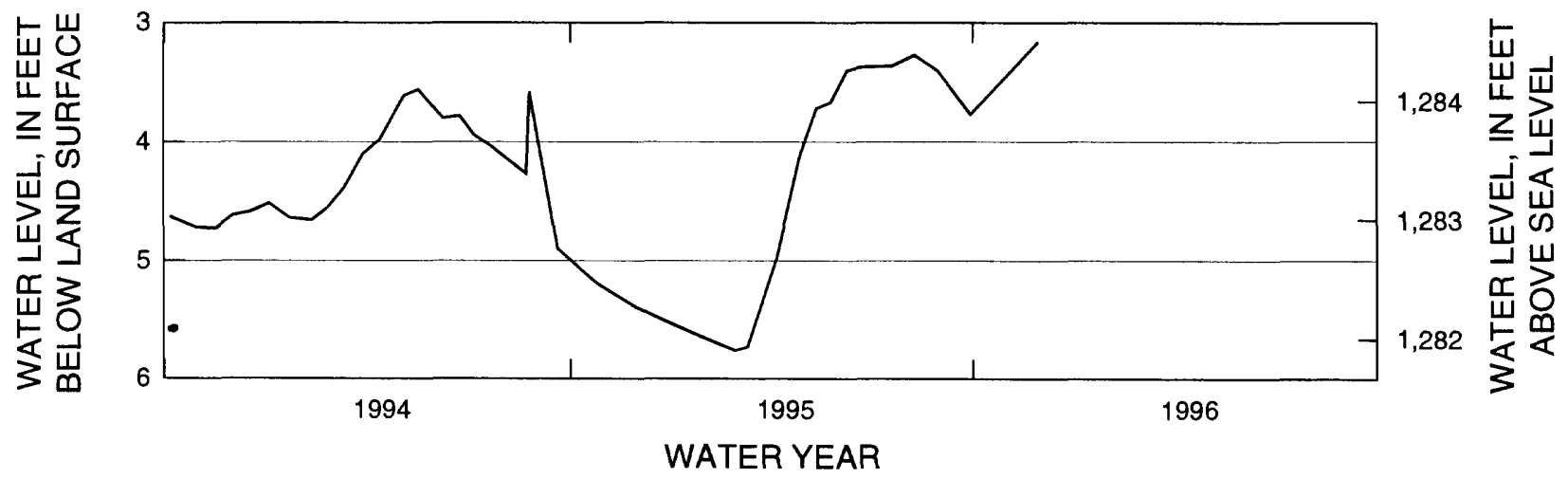

Figure 21. Hydrograph for observation well 110N62W3DCCC2, CO-27-90, water years 1994-96. 
LOCAL WELL NUMBER: 110N62W4AADA

SITE IDENTIFIER: 442204098163101

OTHER IDENTIFIER: CO-24-90

ALTITUDE OF LAND SURFACE: $1,289.94$ feet

MEASURING POINT: 2.46 feet above land surface

AQUIFER: Warren

PERIOD OF RECORD: November 6, 1990, to November 29, 1995

EXTREMES FOR PERIOD SHOWN: Highest, 2.47 feet, November 29, 1995; lowest, 6.21 feet, October 6, 1993.

EXTREMES FOR PERIOD OF RECORD: Highest, 2.47 feet, November 29, 1995; lowest, 13.18 feet, November 6, 1990.
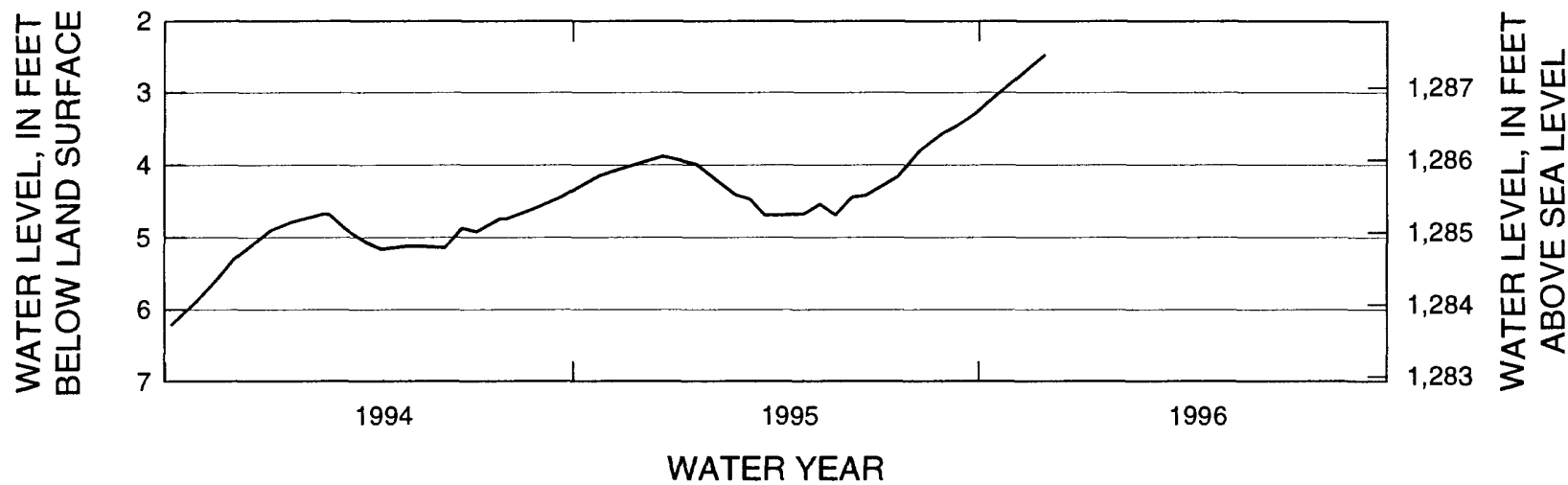

WATER YEAR

Figure 22. Hydrograph for observation well 110N62W4AADA, CO-24-90, water years 1994-96.

LOCAL WELL NUMBER: 110N62W4BBBB

SITE IDENTIFIER: 442213098174301

OTHER IDENTIFIER: CO-04-90

ALTITUDE OF LAND SURFACE: $1,301.84$ feet

MEASURING POINT: 2.71 feet above land surface

AQUIFER: Warren

PERIOD OF RECORD: August 6, 1990, to November 29, 1995

EXTREMES FOR PERIOD SHOWN: Highest, 10.05 feet, September 11, 1995; lowest, 24.06 feet, March 11, 1994.

EXTREMES FOR PERIOD OF RECORD: Highest, 10.05 feet, September 11, 1995; lowest, 35.64 feet, August 15, 1990.
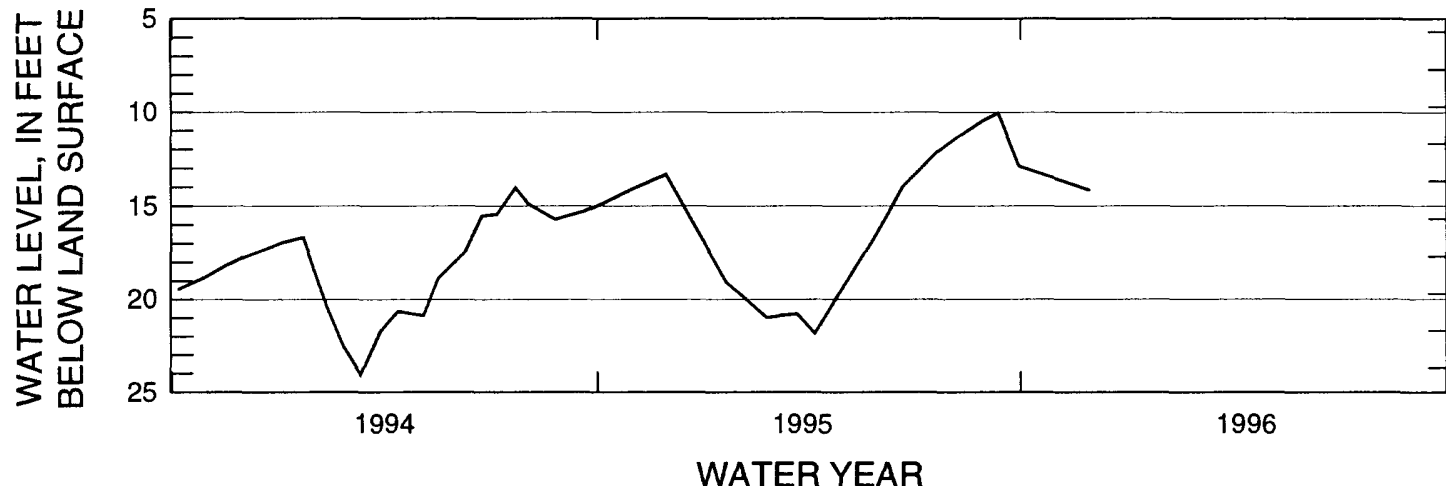

WATER YEAR

Figure 23. Hydrograph for observation well 110N62W4BBBB, C0-04-90, water years 1994-96. 
LOCAL WELL NUMBER: 110N62W4CDDD

SITE IDENTIFIER: 442123098171501

OTHER IDENTIFIER: CO-15-90

ALTITUDE OF LAND SURFACE: $1,298.64$ feet

MEASURING POINT: 2.69 feet above land surface

AQUIFER: Warren

PERIOD OF RECORD: August 15, 1990, to November 29, 1995

EXTREMES FOR PERIOD SHOWN: Highest, 8.17 feet, September 11, 1995; lowest, 26.11 feet, March 7, 1994.

EXTREMES FOR PERIOD OF RECORD: Highest, 8.17 feet, September 11, 1995; lowest, 36.35 feet,

November 21, 1990.

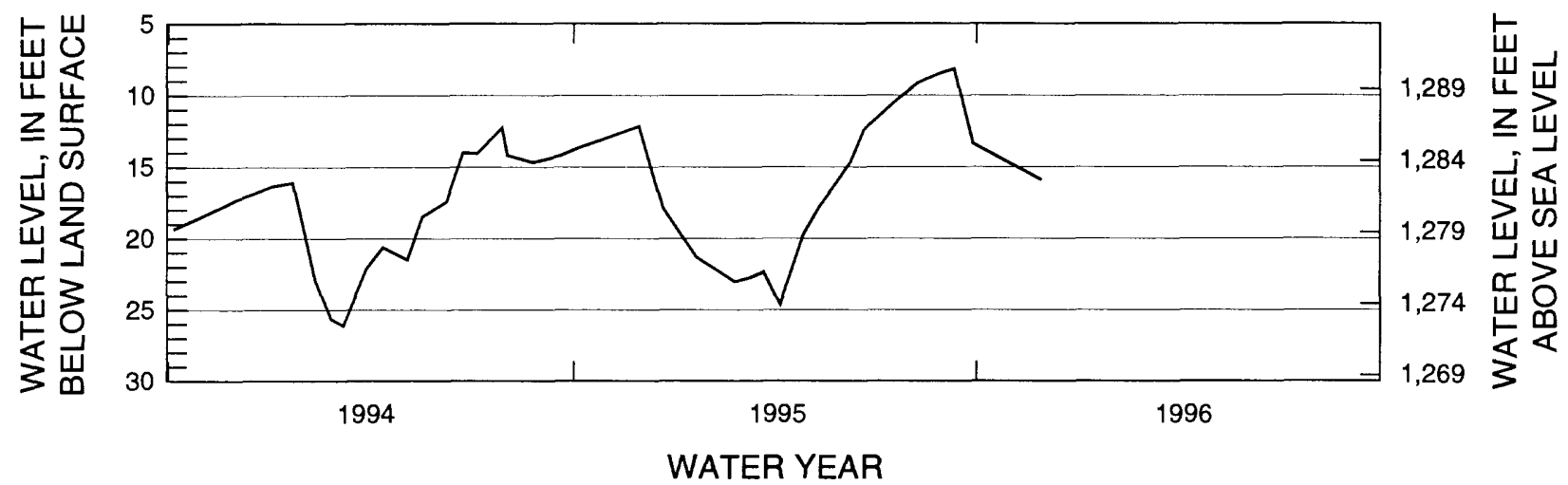

Figure 24. Hydrograph for observation well 110N62W4CDDD, CO-15-90, water years 1994-96.

LOCAL WELL NUMBER: 110N62W4DDDD

SITE IDENTIFIER: 442123098163101

OTHER IDENTIFIER: CO-25-90

ALTITUDE OF LAND SURFACE: $1,293.20$ feet

MEASURING POINT: 2.55 feet above land surface

AQUIFER: Warren

PERIOD OF RECORD: November 6, 1990, to November 29, 1995

EXTREMES FOR PERIOD SHOWN: Highest, 0.01 feet, May 12, 1995; lowest, 6.59 feet, January 20, 1995.

EXTREMES FOR PERIOD OF RECORD: Highest, 0.01 feet, May 12, 1995; lowest, 16.29 feet, April 15, 1991.
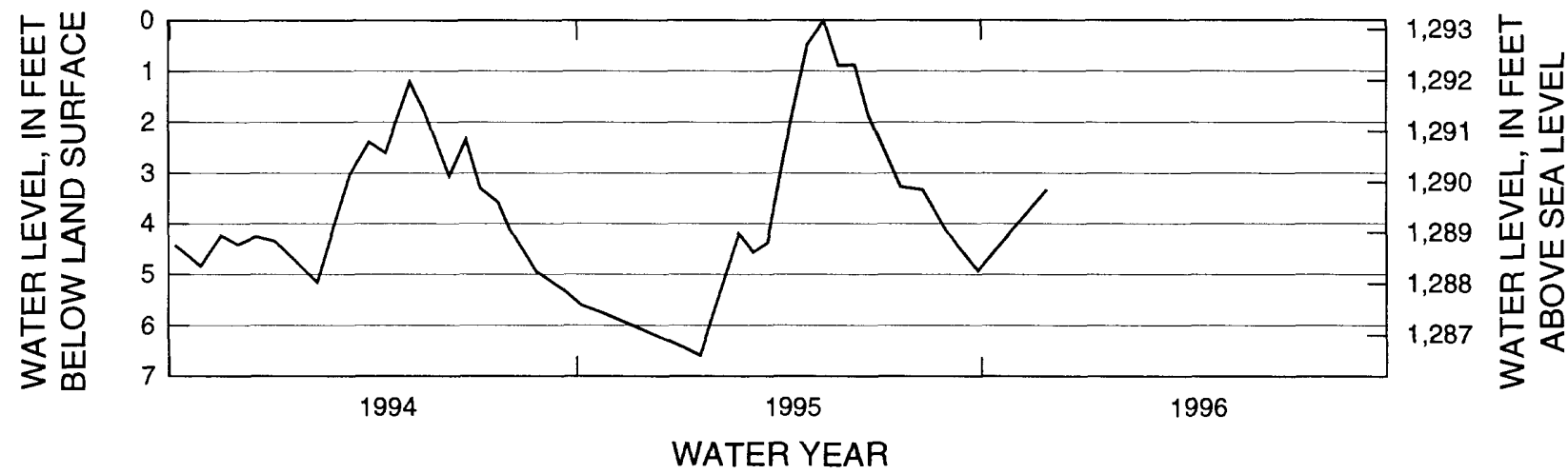

Figure 25. Hydrograph for observation well 110N62W4DDDD, CO-25-90, water years 1994-96. 
LOCAL WELL NUMBER: 110N62W5ADDD

SITE IDENTIFIER: 442150098174401

OTHER IDENTIFIER: CO-05-90

ALTITUDE OF LAND SURFACE: $1,299.75$ feet

MEASURING POINT: 2.40 feet above land surface

AQUIFER: Warren

PERIOD OF RECORD: August 6, 1990, to November 29, 1995

EXTREMES FOR PERIOD SHOWN: Highest, 8.39 feet, September 11, 1995; lowest, 23.65 feet, March 7, 1994. EXTREMES FOR PERIOD OF RECORD: Highest, 8.39 feet, September 11, 1995; lowest, 34.51 feet, September 27, 1990.

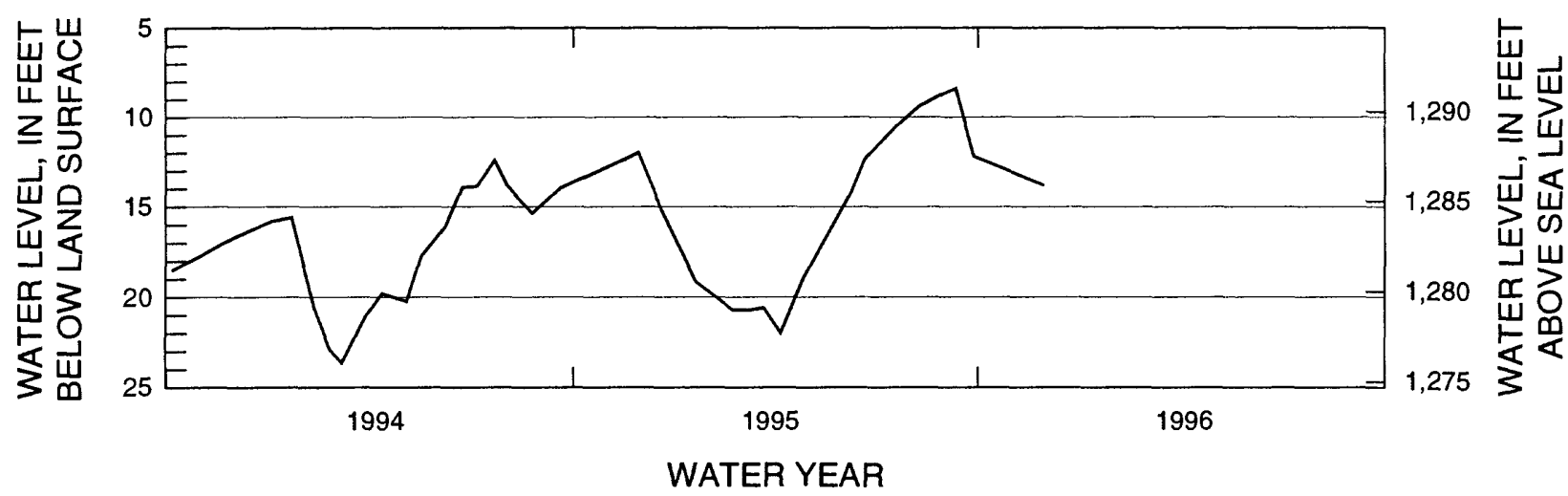

Figure 26. Hydrograph for observation well 110N62W5ADDD, CO-05-90, water years 1994-96.

LOCAL WELL NUMBER: 110N62W5BBBB2

SITE IDENTIFIER: 442213098185602

OTHER IDENTIFIER: CO-03-90

ALTITUDE OF LAND SURFACE: $1,308.40$ feet

MEASURING POINT: 2.63 feet above land surface

AQUIFER: Warren

PERIOD OF RECORD: August 6, 1990, to November 29, 1995

EXTREMES FOR PERIOD SHOWN: Highest, 16.16 feet, September 11, 1995; lowest, 28.36 feet, March 11, 1994.

EXTREMES FOR PERIOD OF RECORD: Highest, 16.16 feet, September 11, 1995; lowest, 40.59 feet, September 27, 1990.
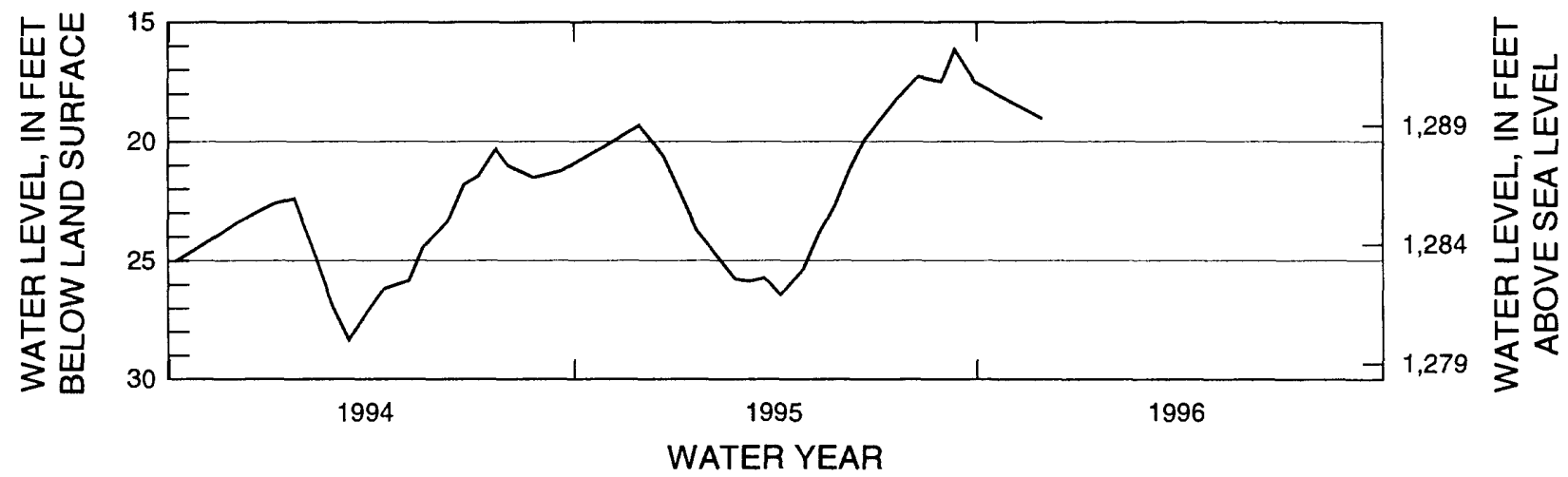

Figure 27. Hydrograph for observation well 110N62W5BBBB2, C0-03-90, water years 1994-96. 
LOCAL WELL NUMBER: 110N62W5CCCB2

SITE IDENTIFIER: 442128098185402

OTHER IDENTIFIER: CO-31-90

ALTITUDE OF LAND SURFACE: $1,310.81$ feet

MEASURING POINT: 2.63 feet above land surface

AQUIFER: Warren

PERIOD OF RECORD: November 5, 1990, to November 29, 1995

EXTREMES FOR PERIOD SHOWN: Highest, 20.07 feet, September 11, 1995; lowest, 36.10 feet, March 28, 1994.

EXTREMES FOR PERIOD OF RECORD: Highest, 20.07 feet, September 11, 1995; lowest, 45.40 feet,

December 26, 1990.

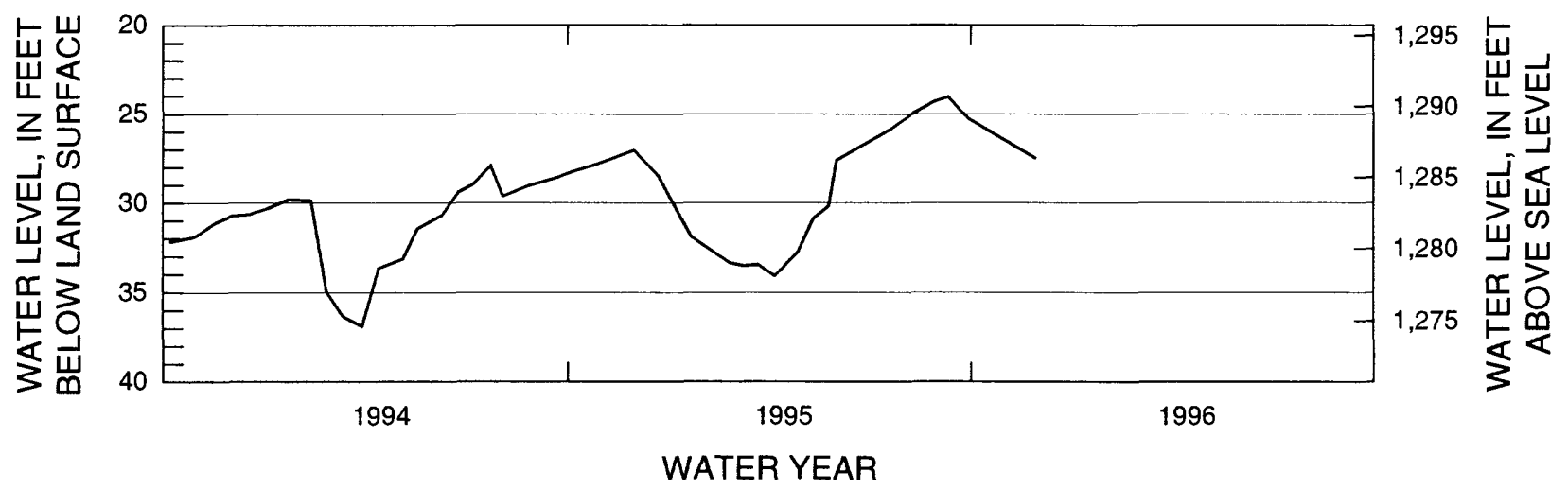

Figure 28. Hydrograph for observation well 110N62W5CCCB2, CO-31-90, water years 1994-96.

LOCAL WELL NUMBER: 110N62W5DCCC

SITE IDENTIFIER: 442124098181601

OTHER IDENTIFIER: CO-14-90

ALTITUDE OF LAND SURFACE: $1,313.83$ feet

MEASURING POINT: 2.96 feet above land surface

AQUIFER: Warren

PERIOD OF RECORD: August 15, 1990, to November 29, 1995

EXTREMES FOR PERIOD SHOWN: Highest, 23.12 feet, September 11, 1995; lowest, 39.62 feet, March 7, 1994.

EXTREMES FOR PERIOD OF RECORD: Highest, 23.12 feet, September 11, 1995; lowest, 50.06 feet, November 5, 1990.

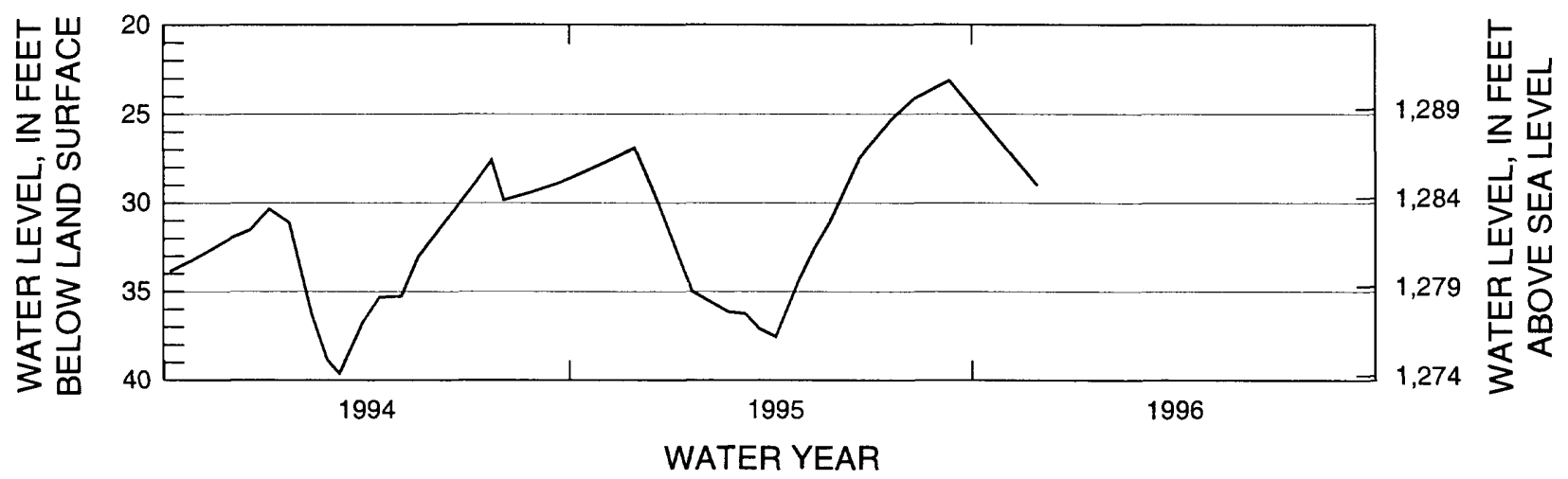

Figure 29. Hydrograph for observation well 110N62W5DCCC, CO-14-90, water years 1994-96. 
LOCAL WELL NUMBER: 110N62W6BBBB

SITE IDENTIFIER: 442213098200701

OTHER IDENTIFIER: CO-23-90

ALTITUDE OF LAND SURFACE: $1,305.96$ feet

MEASURING POINT: 2.41 feet above land surface

AQUIFER: Warren

PERIOD OF RECORD: November 5, 1990, to November 29, 1995

EXTREMES FOR PERIOD SHOWN: Highest, 12.90 feet, September 11, 1995; lowest, 23.03 feet, March 11, 1994.

EXTREMES FOR PERIOD OF RECORD: Highest, 12.90 feet, September 11, 1995; lowest, 34.43 feet, November 5, 1990.
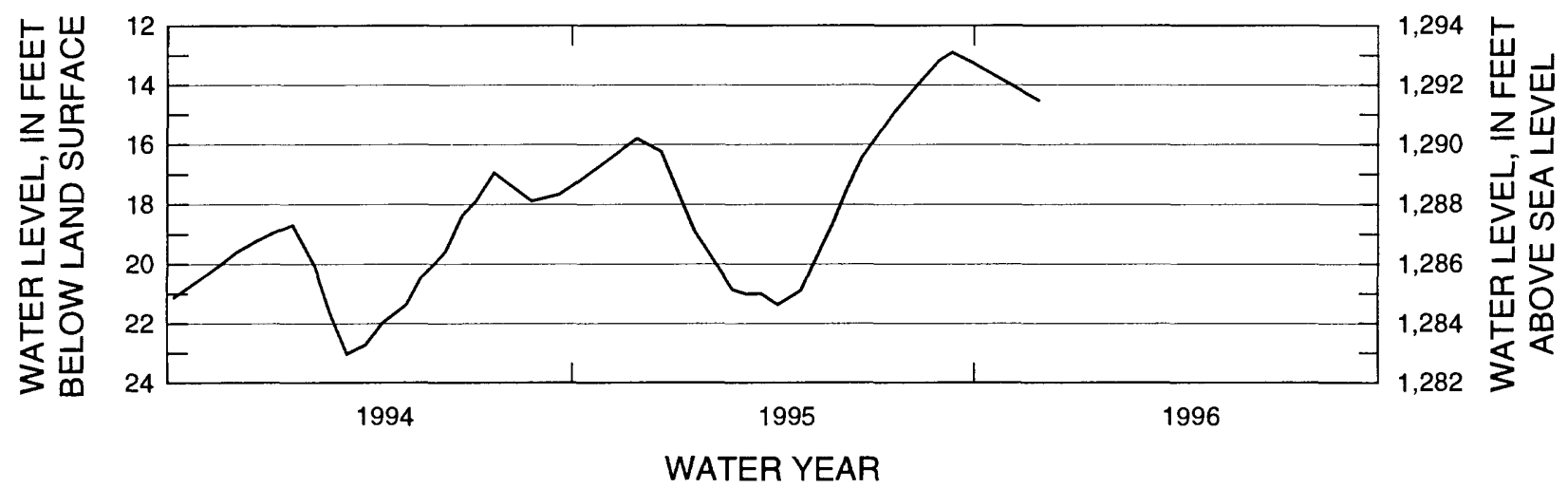

Figure 30. Hydrograph for observation well 110N62W6BBBB, CO-23-90, water years 1994-96.

LOCAL WELL NUMBER: 110N62W8CCCC

SITE IDENTIFIER: 442002098185301

OTHER IDENTIFIER: CO-01-90

ALTITUDE OF LAND SURFACE: $1,321.89$ feet

MEASURING POINT: 2.32 feet above land surface

AQUIFER: Warren

PERIOD OF RECORD: August 6, 1990, to November 29, 1995

EXTREMES FOR PERIOD SHOWN: Highest, 32.31 feet, September 11, 1995; lowest, 49.81 feet, March 11, 1994.

EXTREMES FOR PERIOD OF RECORD: Highest, 32.31 feet, September 11, 1995, lowest, 60.90 feet, November 21, 1990.
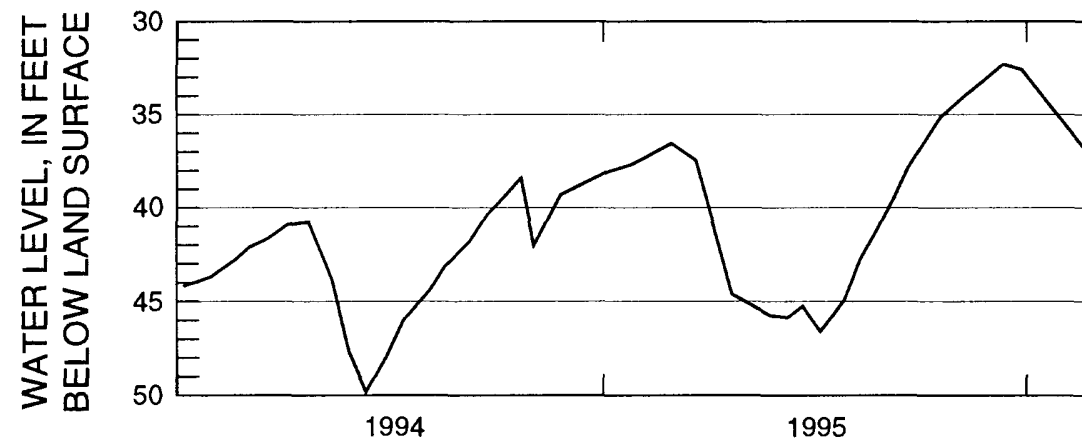

WATER YEAR

Figure 31. Hydrograph for observation well 110N62W8CCCC, CO-01-90, water years 1994-96. 
LOCAL WELL NUMBER: 110N62W9BABB

SITE IDENTIFIER: 442122098172002

OTHER IDENTIFIER: CO-06-90

ALTITUDE OF LAND SURFACE: $1,297.53$ feet

MEASURING POINT: 2.71 feet above land surface

AQUIFER: Warren

PERIOD OF RECORD: August 6, 1990, to November 29, 1995

EXTREMES FOR PERIOD SHOWN: Highest, 6.86 feet, September 11, 1995; lowest, 26.03 feet, March 3, 1994.

EXTREMES FOR PERIOD OF RECORD: Highest, 6.86 feet, September 11, 1995; lowest, 35.67 feet,

November 21, 1990.
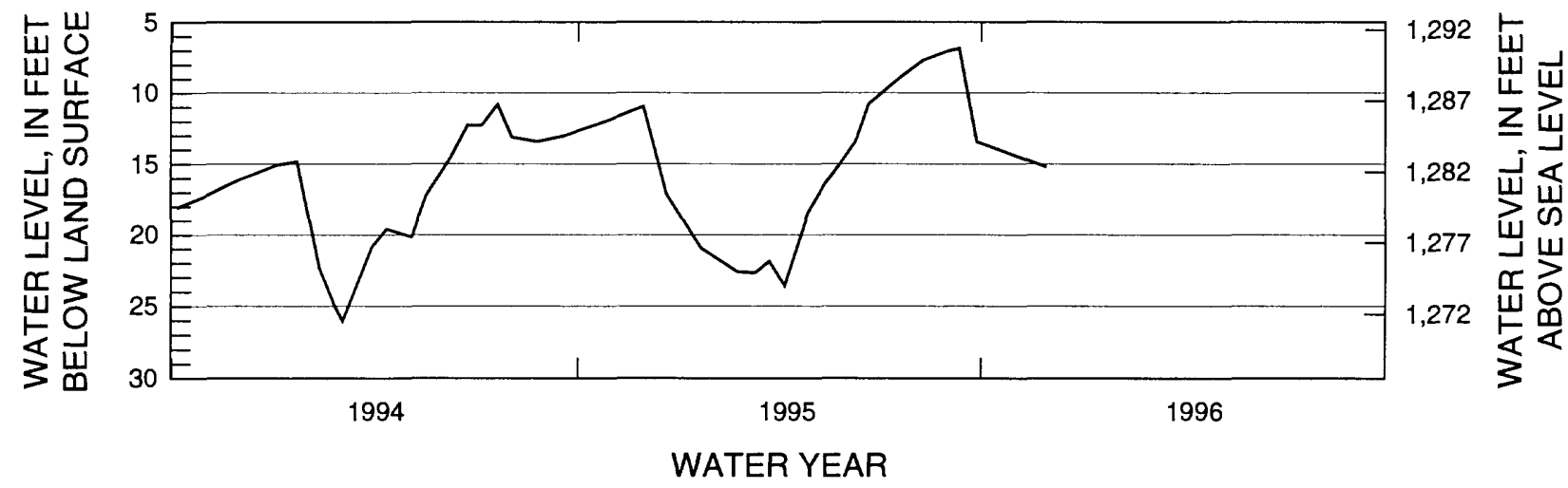

Figure 32. Hydrograph for observation well 110N62W9BABB, CO-06-90, water years 1994-96.

LOCAL WELL NUMBER: 110N62W9BBAC

SITE IDENTIFIER: 442118098173101

OTHER IDENTIFIER: CO-55-90

ALTITUDE OF LAND SURFACE: $1,296.45$ feet

MEASURING POINT: 2.39 feet above land surface

AQUIFER: Warren

PERIOD OF RECORD: November 6, 1990, to November 29, 1995

EXTREMES FOR PERIOD SHOWN: Highest, 5.63 feet, September 11, 1995; lowest, 25.34 feet, March 7, 1994. EXTREMES FOR PERIOD OF RECORD: Highest, 5.63 feet, September 11, 1995; lowest, 35.69 feet, November 21, 1990.
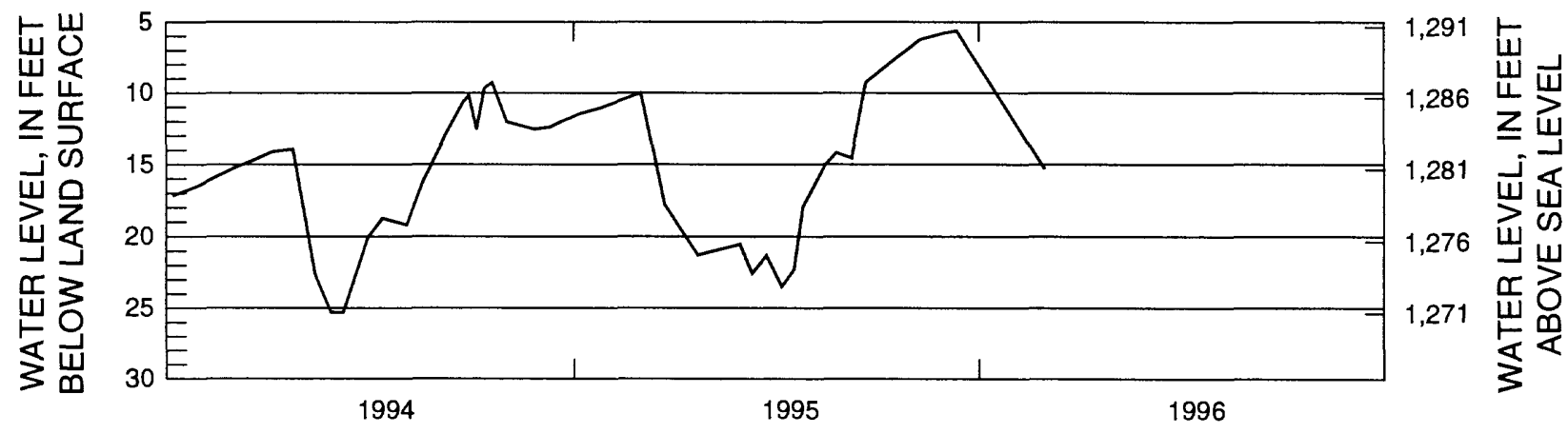

Figure 33. Hydrograph for observation well 110N62W9BBAC, C0-55-90, water years 1994-96. 
LOCAL WELL NUMBER: 110N62W9BBBA

SITE IDENTIFIER: 442119098173601

OTHER IDENTIFIER: CO-65-90

ALTITUDE OF LAND SURFACE: $1,297.19$ feet

MEASURING POINT: 2.62 feet above land surface

AQUIFER: Warren

PERIOD OF RECORD: November 6, 1990, to October 25, 1994

EXTREMES FOR PERIOD SHOWN: Highest, 9.33 feet, July 20, 1994; lowest, 27.13 feet, March 11, 1994.

EXTREMES FOR PERIOD OF RECORD: Highest, 9.33 feet, July 20, 1994; lowest, 36.69 feet, November 21, 1990.

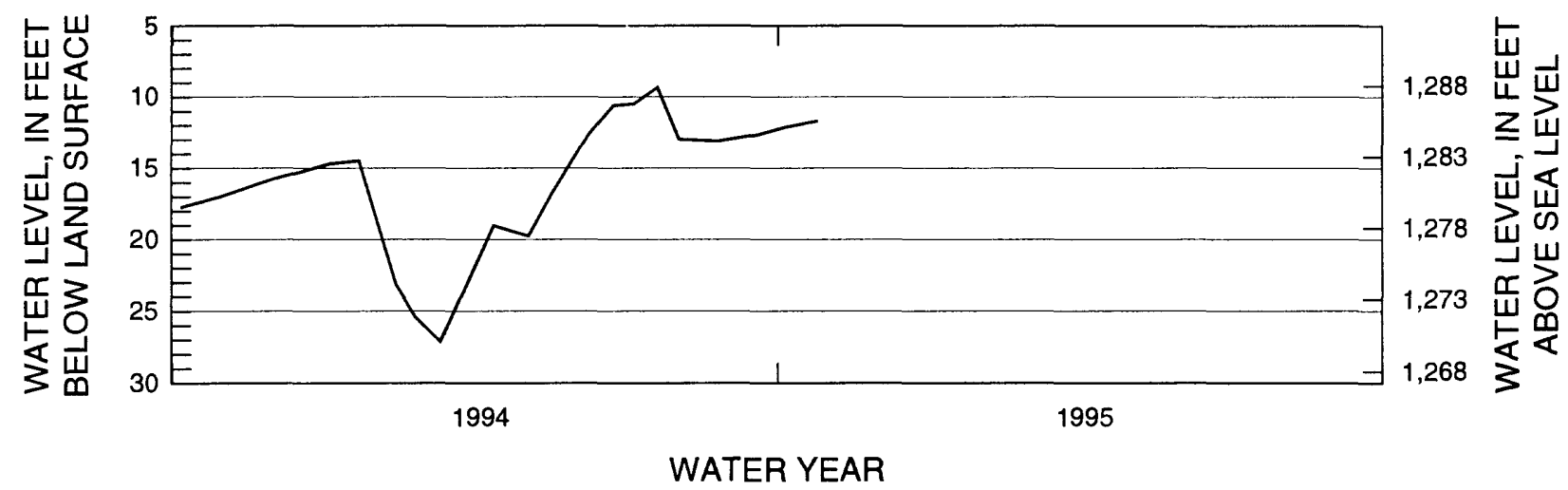

Figure 34. Hydrograph for observation well 110N62W9BBBA, CO-65-90, water years 1994-95.

LOCAL WELL NUMBER: 110N62W9BBBA2

SITE IDENTIFIER: 442119098173602

OTHER IDENTIFIER: CO-66-90

ALTITUDE OF LAND SURFACE: $1,297.19$ feet

MEASURING POINT: 2.35 feet above land surface

AQUIFER: Warren

PERIOD OF RECORD: November 6, 1990, to November 29, 1995

EXTREMES FOR PERIOD SHOWN: Highest, 6.13 feet, September 11, 1995; lowest, 25.61 feet, March 7, 1994.

EXTREMES FOR PERIOD OF RECORD: Highest, 6.13 feet, September 11, 1995; lowest, 35.88 feet,

November 6, 1990.
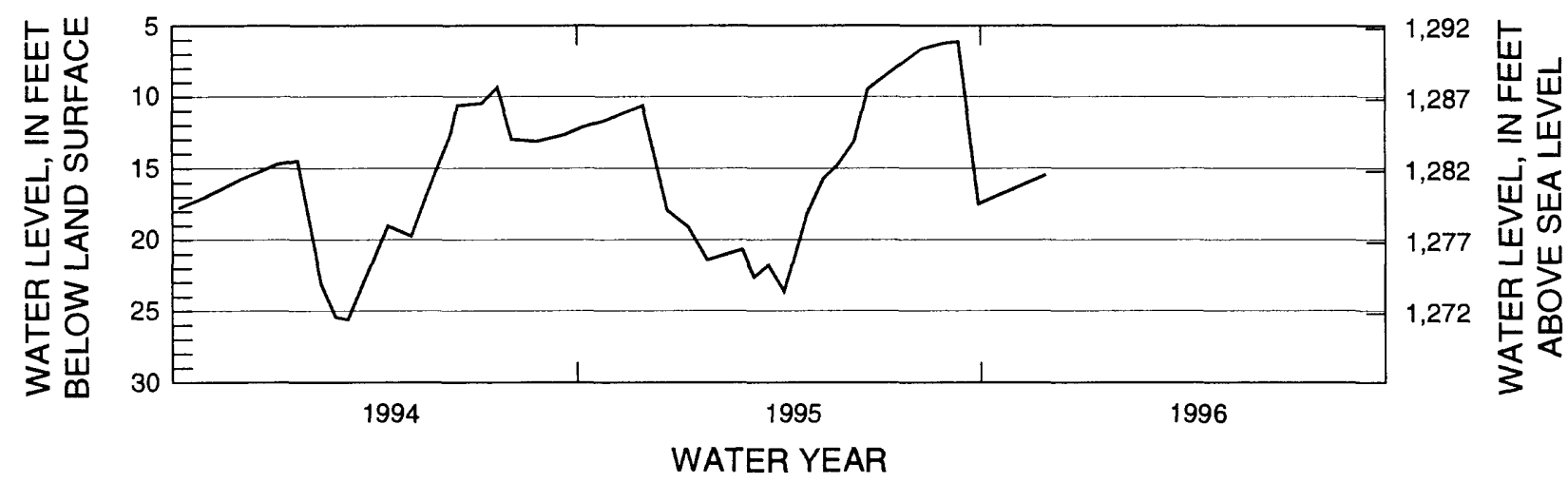

Figure 35. Hydrograph for observation well 110N62W9BBBA2, C0-66-90, water years 1994-96. 
LOCAL WELL NUMBER: 110N62W9BBBA3

SITE IDENTIFIER: 442119098173603

OTHER IDENTIFIER: CO-67-90

ALTITUDE OF LAND SURFACE: $1,297.19$ feet

MEASURING POINT: 2.34 feet above land surface

AQUIFER: Warren

PERIOD OF RECORD: November 6, 1990, to October 25, 1994

EXTREMES FOR PERIOD SHOWN: Highest, 9.41 feet, July 20, 1994; lowest, 27.15 feet, March 11, 1994.

EXTREMES FOR PERIOD OF RECORD: Highest, 9.41 feet, July 20, 1994; lowest, 35.87 feet, November 6, 1990.
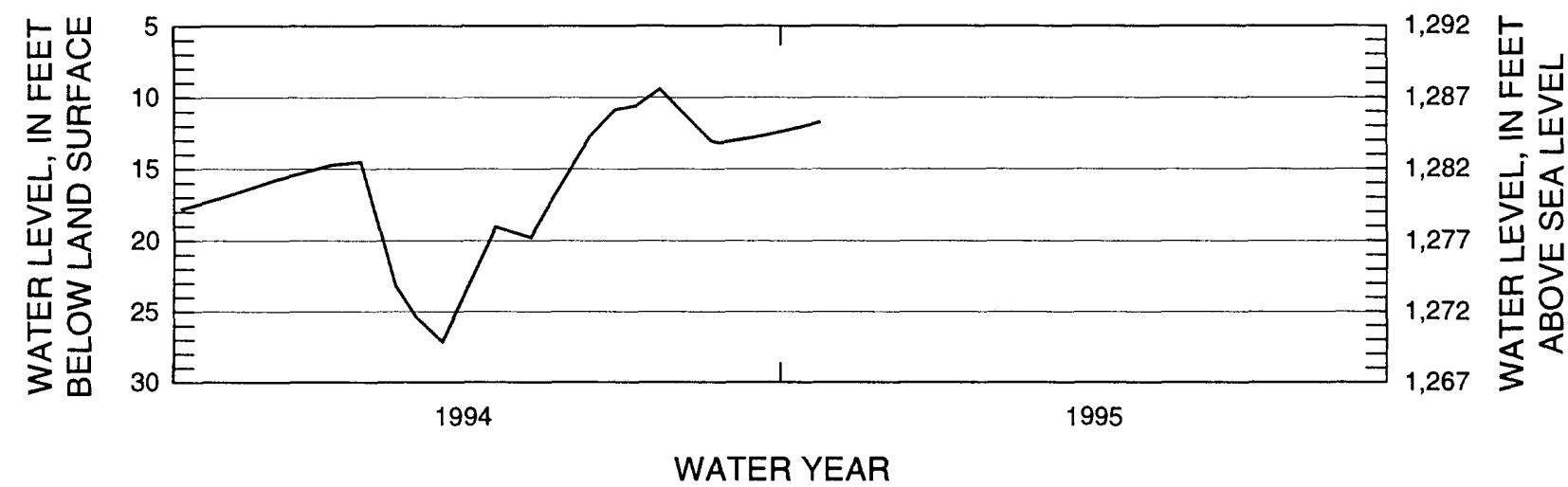

Figure 36. Hydrograph for observation well 110N62W9BBBA3, CO-67-90, water years 1994-95.

LOCAL WELL NUMBER: 110N62W9BBBA4

SITE IDENTIFIER: 442119098173604

OTHER IDENTIFIER: A-01-90

ALTITUDE OF LAND SURFACE: $1,297.19$ feet

MEASURING POINT: 2.78 feet above land surface

AQUIFER: Till

PERIOD OF RECORD: November 2, 1990, to November 29, 1995

EXTREMES FOR PERIOD SHOWN: Highest, 2.29 feet, June 21, 1995; lowest, 8.85 feet, March 23, 1995.

EXTREMES FOR PERIOD OF RECORD: Highest, 2.29 feet, June 21, 1995; lowest, 18.67 feet, November 6, 1990.

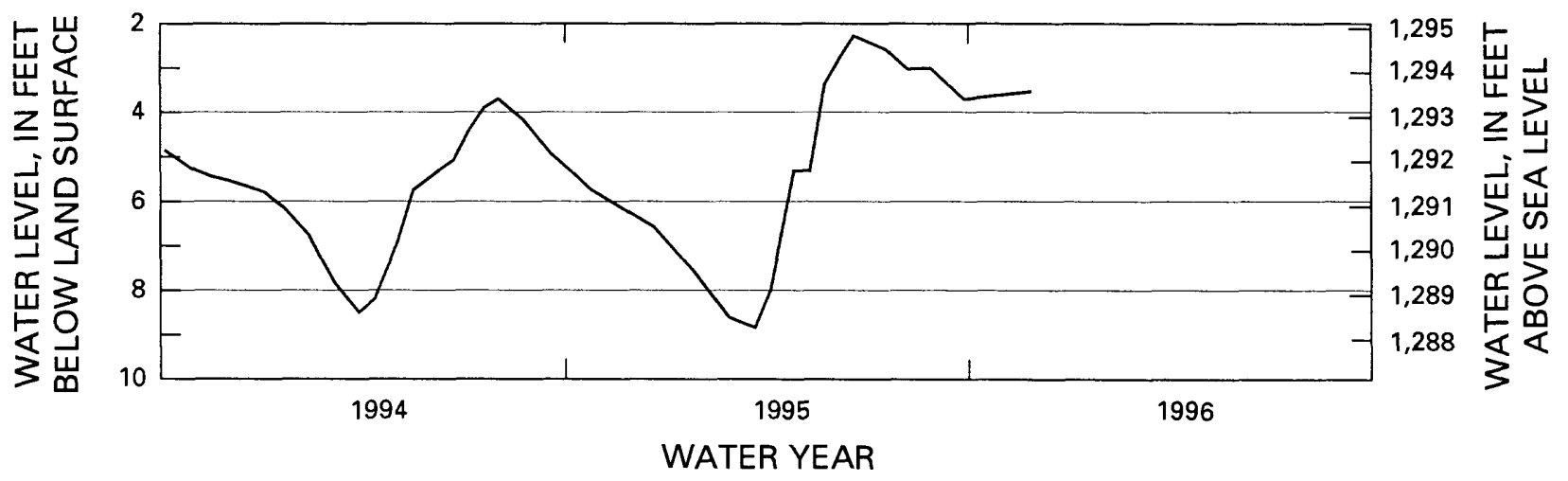

Figure 37. Hydrograph for observation well 110N62W9BBBA4, A-01-90, water years 1994-96. 
LOCAL WELL NUMBER: 110N62W9BBBA5

SITE IDENTIFIER: 442119098173605

OTHER IDENTIFIER: A-02-90

ALTITUDE OF LAND SURFACE: $1,297.19$ feet

MEASURING POINT: 2.63 feet above land surface

AQUIFER: Till

PERIOD OF RECORD: November 6, 1990, to November 29, 1995

EXTREMES FOR PERIOD SHOWN: Highest, -0.75 feet, June 21, 1995; lowest, 7.51 feet, February $27,1995$. EXTREMES FOR PERIOD OF RECORD: Highest, -0.75 feet, June 21, 1995; lowest, 12.22 feet, February 21, 1991.
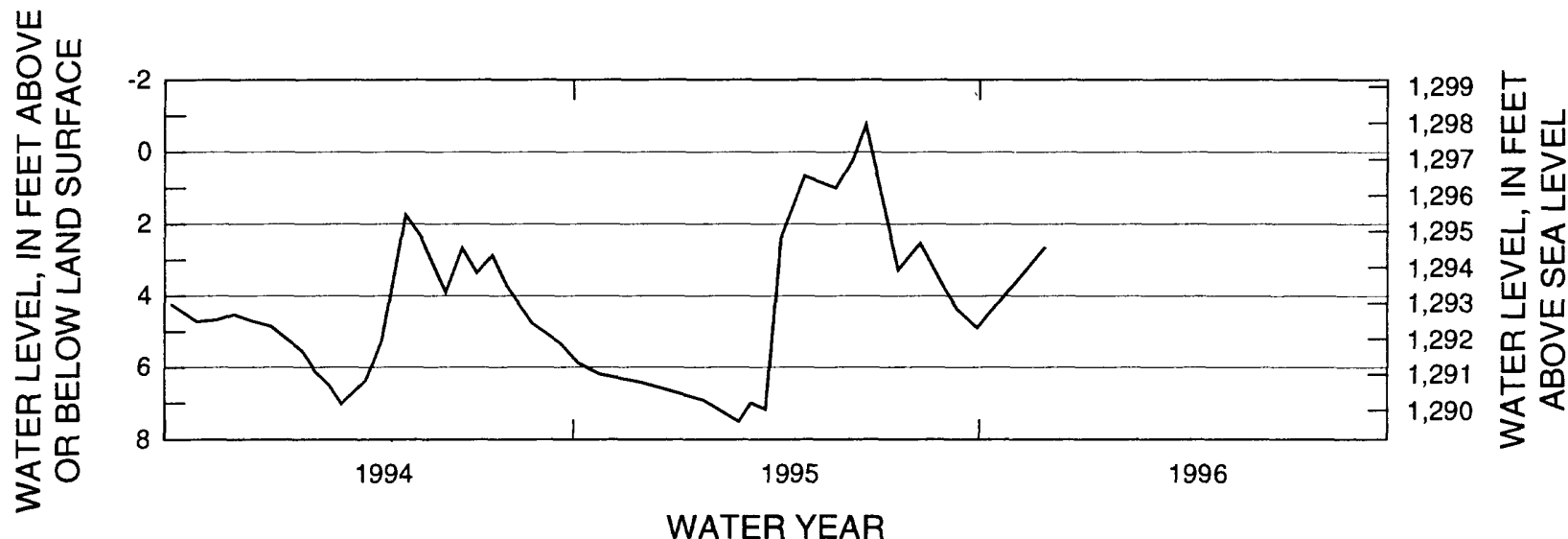

WATER YEAR

Figure 38. Hydrograph for observation well 110N62W9BBBA5, A-02-90, water years 1994-96.

LOCAL WELL NUMBER: 110N62W9BBBA6

SITE IDENTIFIER: 442119098173606

OTHER IDENTIFIER: A-03-90

ALTITUDE OF LAND SURFACE: $1,297.19$ feet

MEASURING POINT: 2.32 feet above land surface

AQUIFER: Till

PERIOD OF RECORD: November 6, 1990, to November 29, 1995

EXTREMES FOR PERIOD SHOWN: Highest, 3.91 feet, August 30, 1995; lowest, 11.72 feet, March 7, 1994. EXTREMES FOR PERIOD OF RECORD: Highest, 3.91 feet, August 30, 1995; lowest, 19.48 feet, April 19, 1991.
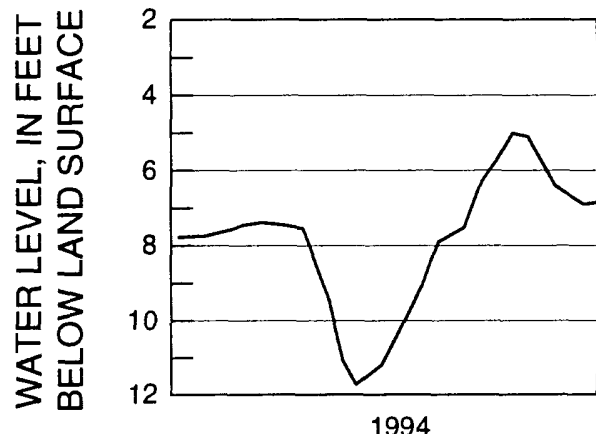

1994

WATER YEAR

Figure 39. Hydrograph for observation well 110N62W9BBBA6, A-03-90, water years 1994-96. 
LOCAL WELL NUMBER: 110N62W9BBBA7

SITE IDENTIFIER: 442119098173607

OTHER IDENTIFIER: A-04-90

ALTITUDE OF LAND SURFACE: $1,297.19$ feet

MEASURING POINT: 2.49 feet above land surface

AQUIFER: Till

PERIOD OF RECORD: November 6, 1990, to November 29, 1995

EXTREMES FOR PERIOD SHOWN: Highest, 3.66 feet, August 9, 1995; lowest, 10.24 feet, March 7, 1994. EXTREMES FOR PERIOD OF RECORD: Highest, 3.66 feet, August 9, 1995; lowest, 17.87 feet, April 19, 1991.
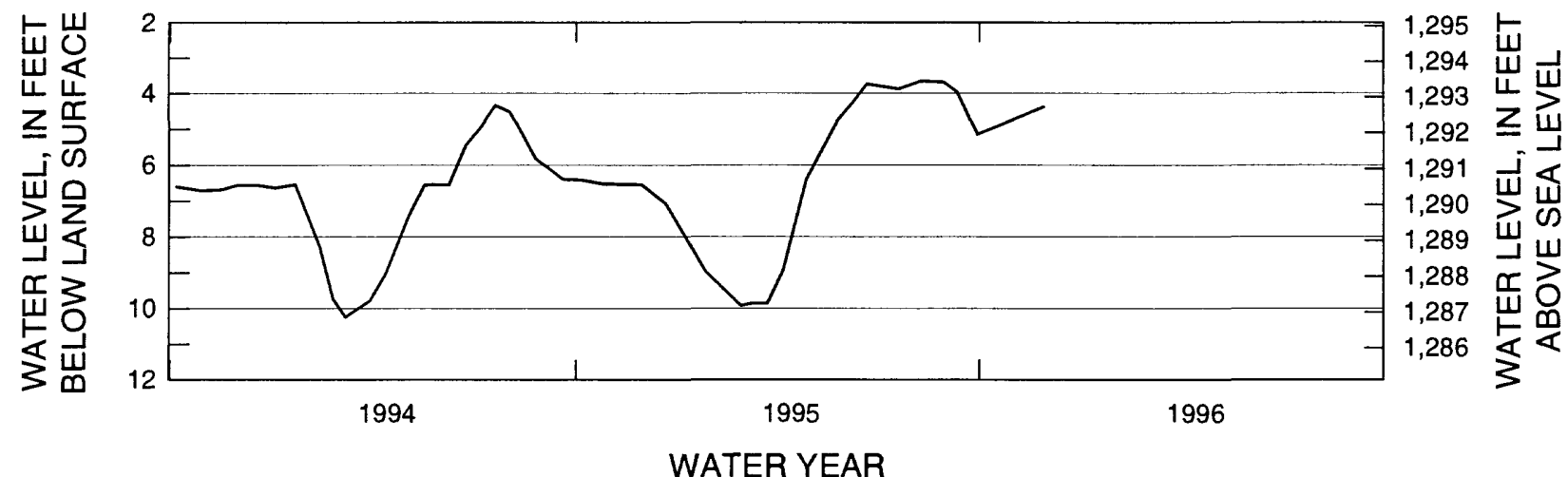

WATER YEAR

Figure 40. Hydrograph for observation well 110N62W9BBBA7, A-04-90, water years 1994-96.

LOCAL WELL NUMBER: 110N62W9BBBB2

SITE IDENTIFIER: 442123098174002

OTHER IDENTIFIER: CO-08-90

ALTITUDE OF LAND SURFACE: $1,295.68$ feet

MEASURING POINT: 2.86 feet above land surface

AQUIFER: Warren

PERIOD OF RECORD: August 6, 1990, to November 29, 1995

EXTREMES FOR PERIOD SHOWN: Highest, 4.71 feet, September 11, 1995; lowest, 24.74 feet, March 11, 1994.

EXTREMES FOR PERIOD OF RECORD: Highest, 4.71 feet, September 11, 1995; lowest, 33.52 feet, November 21, 1990.
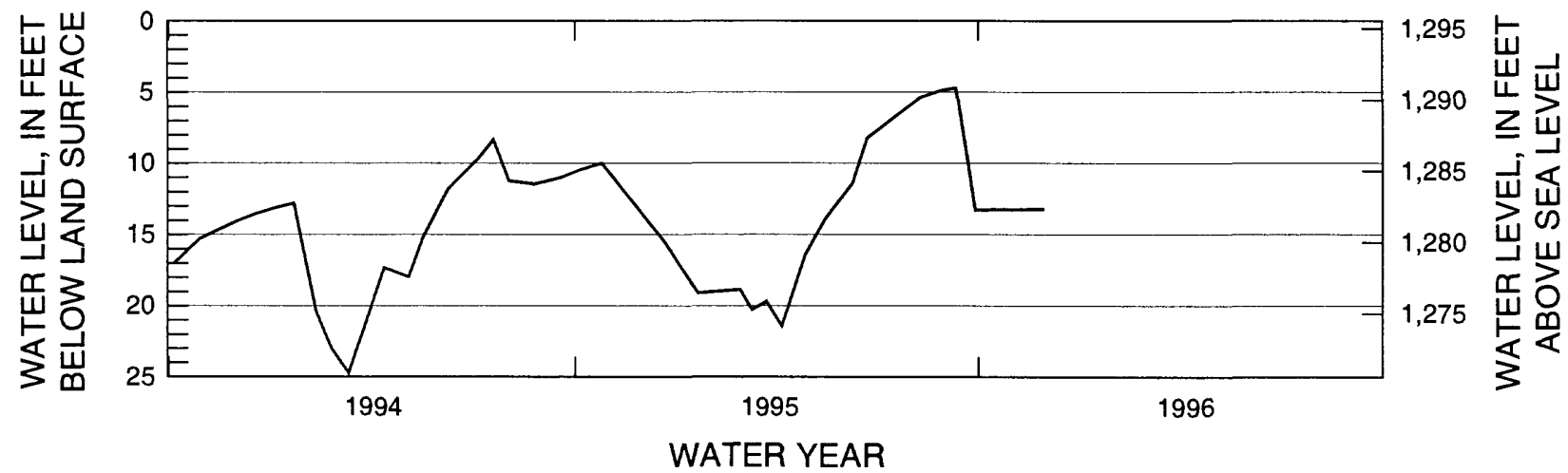

Figure 41. Hydrograph for observation well 110N62W9BBBB2, CO-08-90, water years 1994-96. 
LOCAL WELL NUMBER: 110N62W9BBBC

SITE IDENTIFIER: 442118098174001

OTHER IDENTIFIER: CO-16-90

ALTITUDE OF LAND SURFACE: $1,297.66$ feet

MEASURING POINT: 3.11 feet above land surface

AQUIFER: Warren

PERIOD OF RECORD: August 15, 1990, to November 29, 1995

EXTREMES FOR PERIOD SHOWN: Highest, 6.42 feet, September 11, 1995; lowest, 26.24 feet, March 7, 1994.

EXTREMES FOR PERIOD OF RECORD: Highest, 6.42 feet, September 11, 1995; lowest, 36.80 feet,

November 6, 1990.
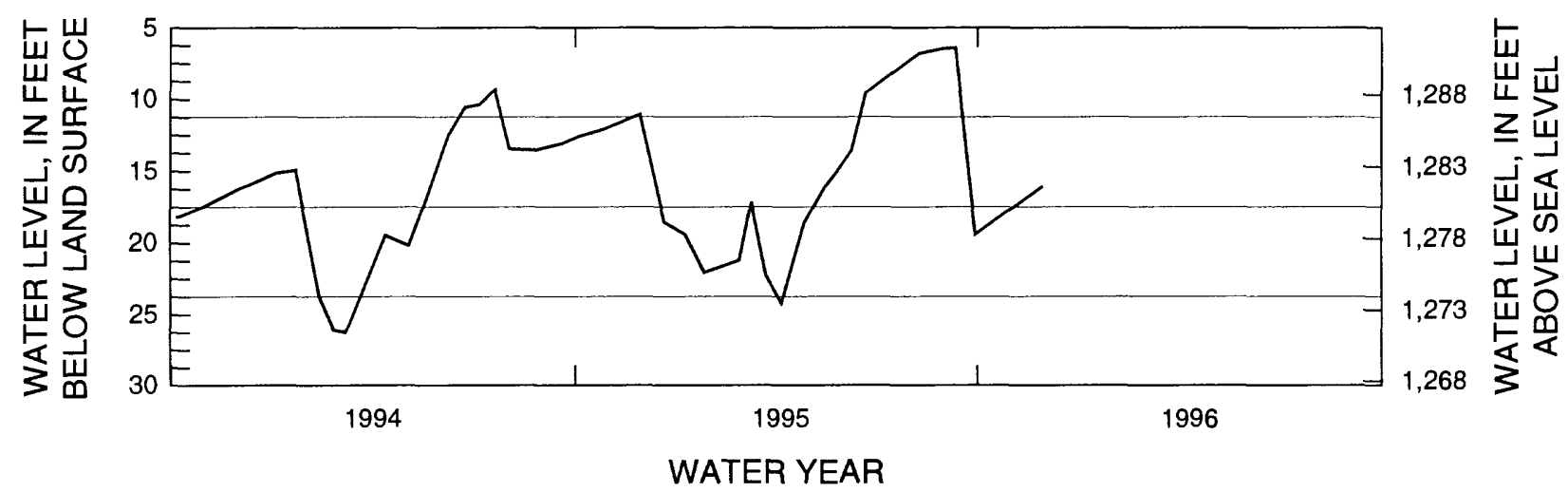

Figure 42. Hydrograph for observation well 110N62W9BBBC, C0-16-90, water years 1994-96.

LOCAL WELL NUMBER: 110N62W9BBBC2

SITE IDENTIFIER: 442118098174002

OTHER IDENTIFIER: CO-33-90

ALTITUDE OF LAND SURFACE: $1,297.65$ feet

MEASURING POINT: 2.60 feet above land surface

AQUIFER: Warren

PERIOD OF RECORD: November 6, 1990, to October 25, 1994

EXTREMES FOR PERIOD SHOWN: Highest, 9.48 feet, July 20, 1994; lowest, 27.79 feet, March 11, 1994.

EXTREMES FOR PERIOD OF RECORD: Highest, 9.48 feet, July 20, 1994; lowest, 36.63 feet, November 6, 1990.
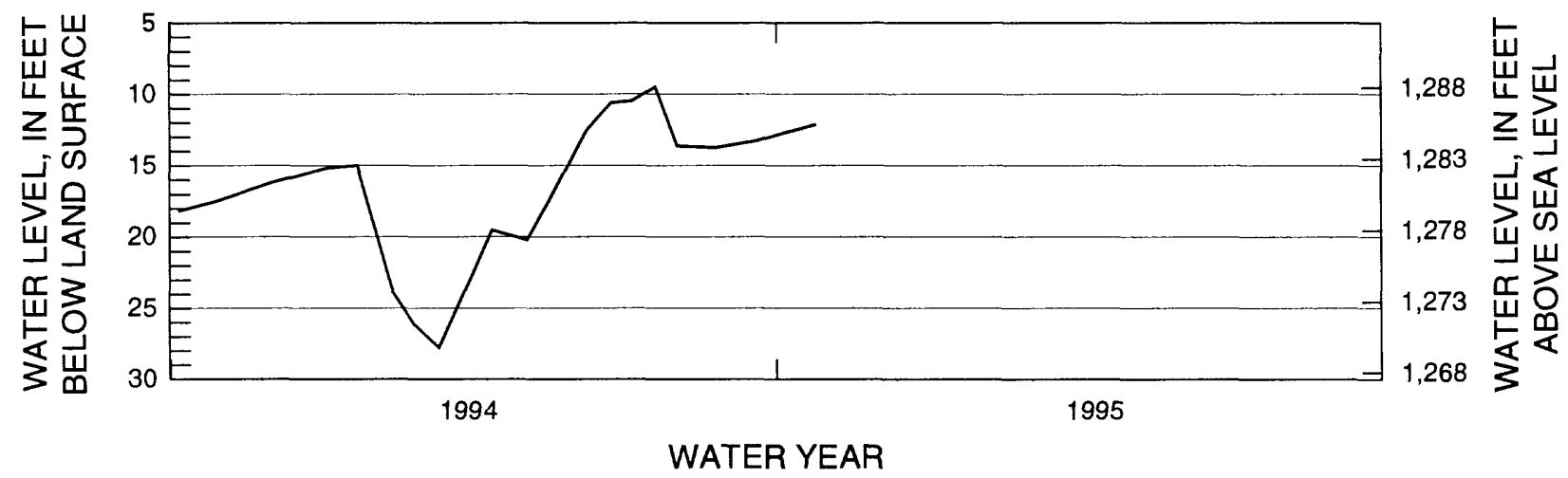

Figure 43. Hydrograph for observation well 110N62W9BBBC2, CO-33-90, water years 1994-95. 
LOCAL WELL NUMBER: 110N62W9BBBC3

SITE IDENTIFIER: 442118098174003

OTHER IDENTIFIER: CO-34-90

ALTITUDE OF LAND SURFACE: $1,297.66$ feet

MEASURING POINT: 2.91 feet above land surface

AQUIFER: Warren

PERIOD OF RECORD: November 6, 1990, to October 25, 1994

EXTREMES FOR PERIOD SHOWN: Highest, 9.35 feet, July 20, 1994; lowest, 27.81 feet, March 11, 1994.

EXTREMES FOR PERIOD OF RECORD: Highest, 9.35 feet, July 20, 1994; lowest, 37.07 feet, November 6, 1990.
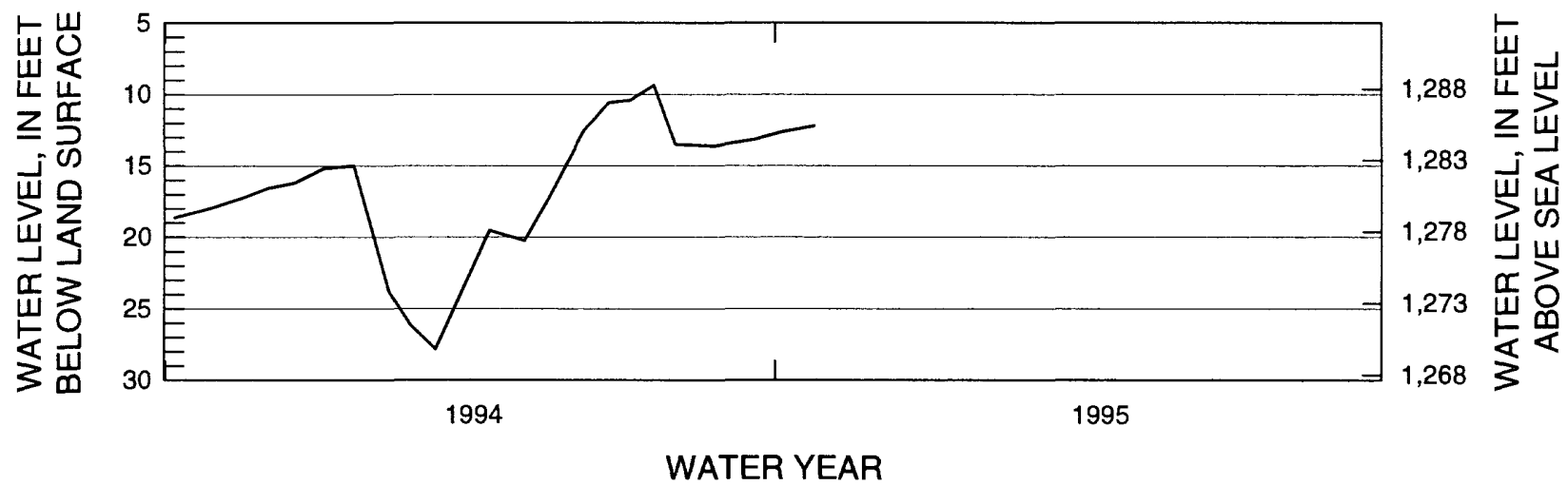

WATER YEAR

Figure 44. Hydrograph for observation well 110N62W9BBBC3, CO-34-90, water years 1994-95.

LOCAL WELL NUMBER: 110N62W9BBBC4

SITE IDENTIFIER: 442118098174004

OTHER IDENTIFIER: CO-35-90

ALTITUDE OF LAND SURFACE: $1,297.66$ feet

MEASURING POINT: 2.90 feet above land surface

AQUIFER: Till

PERIOD OF RECORD: November 6, 1990, to November 29, 1995

EXTREMES FOR PERIOD SHOWN: Highest, 5.72 feet, September 11, 1995; lowest, 17.51 feet, March 7, 1994. EXTREMES FOR PERIOD OF RECORD: Highest, 5.72 feet, September 11, 1995; lowest, 25.87 feet, April 19, 1991.
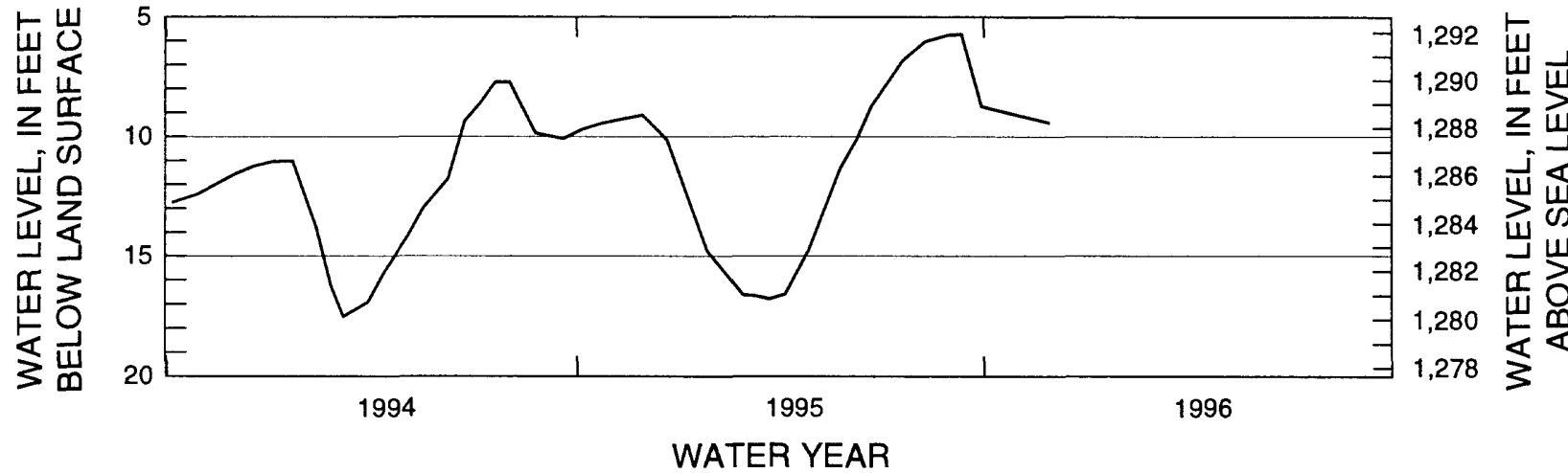

Figure 45. Hydrograph for observation well 110N62W9BBBC4, CO-35-90, water years 1994-96. 
LOCAL WELL NUMBER: 110N62W9BBBC5

SITE IDENTIFIER: 442118098174005

OTHER IDENTIFIER: CO-36-90

ALTITUDE OF LAND SURFACE: $1,297.66$ feet

MEASURING POINT: 3.15 feet above land surface

AQUIFER: Till

PERIOD OF RECORD: November 6, 1990, to November 29, 1995

EXTREMES FOR PERIOD SHOWN: Highest, 0.87 feet, June 9, 1995; lowest, 6.49 feet, March 7, 1994, February 25, 1995.

EXTREMES FOR PERIOD OF RECORD: Highest, 0.87 feet, June 9, 1995; lowest, 11.41 feet, May 1, 1991.
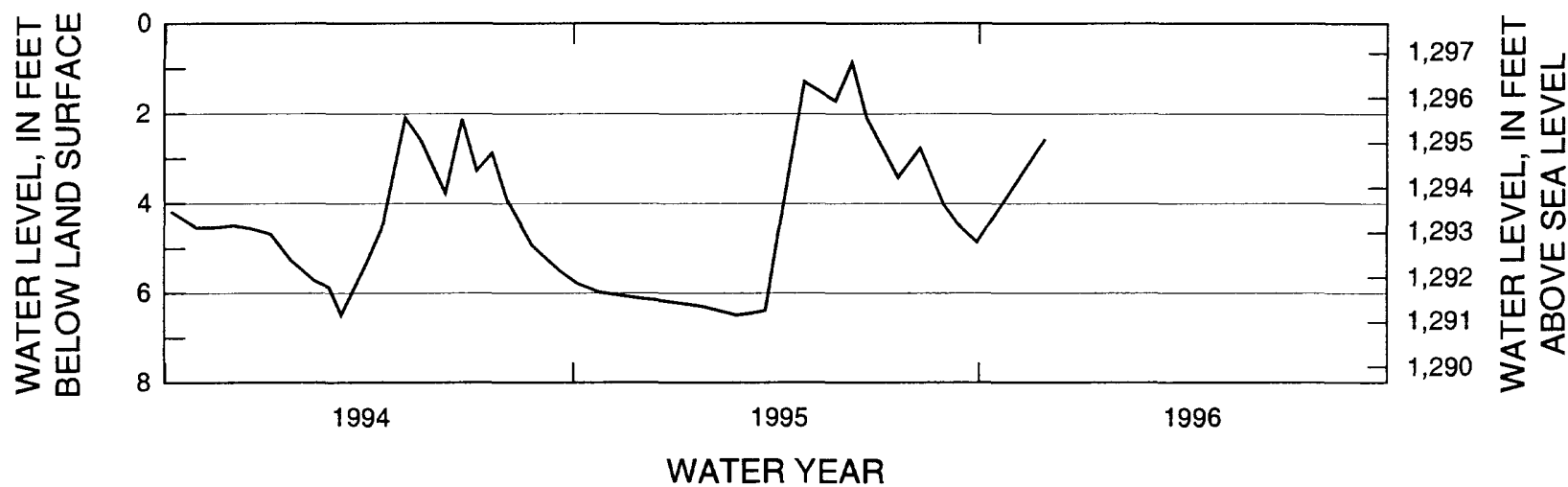

Figure 46. Hydrograph for observation well 110N62W9BBBC5, CO-36-90, waier years 1994-96.

LOCAL WELL NUMBER: 110N62W9BBBC6

SITE IDENTIFIER: 442118098174006

OTHER IDENTIFIER: CO-37-90

ALTITUDE OF LAND SURFACE: $1,297.66$ feet

MEASURING POINT: 3.26 feet above land surface

AQUIFER: Till

PERIOD OF RECORD: November 6, 1990, to November 29, 1995

EXTREMES FOR PERIOD SHOWN: Highest, 0.89 feet, June 9, 1995; lowest, 6.63 feet, February 27, 1995.

EXTREMES FOR PERIOD OF RECORD: Highest, 0.89 feet, June 9, 1995; lowest, 19.77 feet, May 1, 1991.
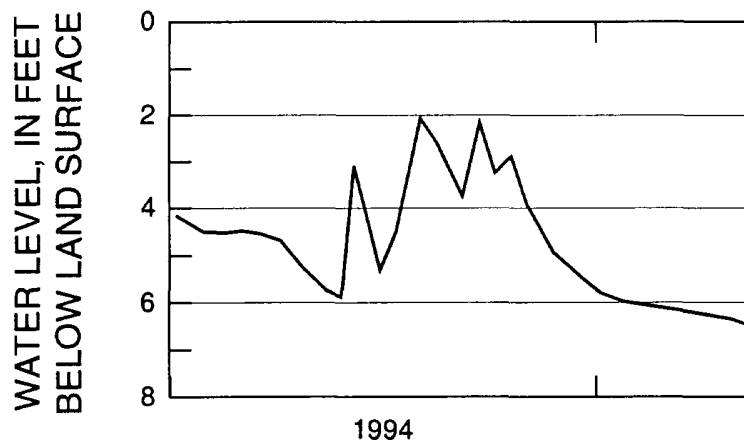
LOCAL WELL NUMBER: 110N62W9BBBC7

SITE IDENTIFIER: 442118098174007

OTHER IDENTIFIER: CO-38-90

ALTITUDE OF LAND SURFACE: $1,297.66$ feet

MEASURING POINT: 2.99 feet above land surface

AQUIFER: Till

PERIOD OF RECORD: November 6, 1990, to November 29, 1995

EXTREMES FOR PERIOD SHOWN: Highest, 4.43 feet, August 9, 1995; lowest, 12.41 feet, March 7, 1994. EXTREMES FOR PERIOD OF RECORD: Highest, 4.43 feet, August 9, 1995; lowest, 21.43 feet, April 19, 1991.
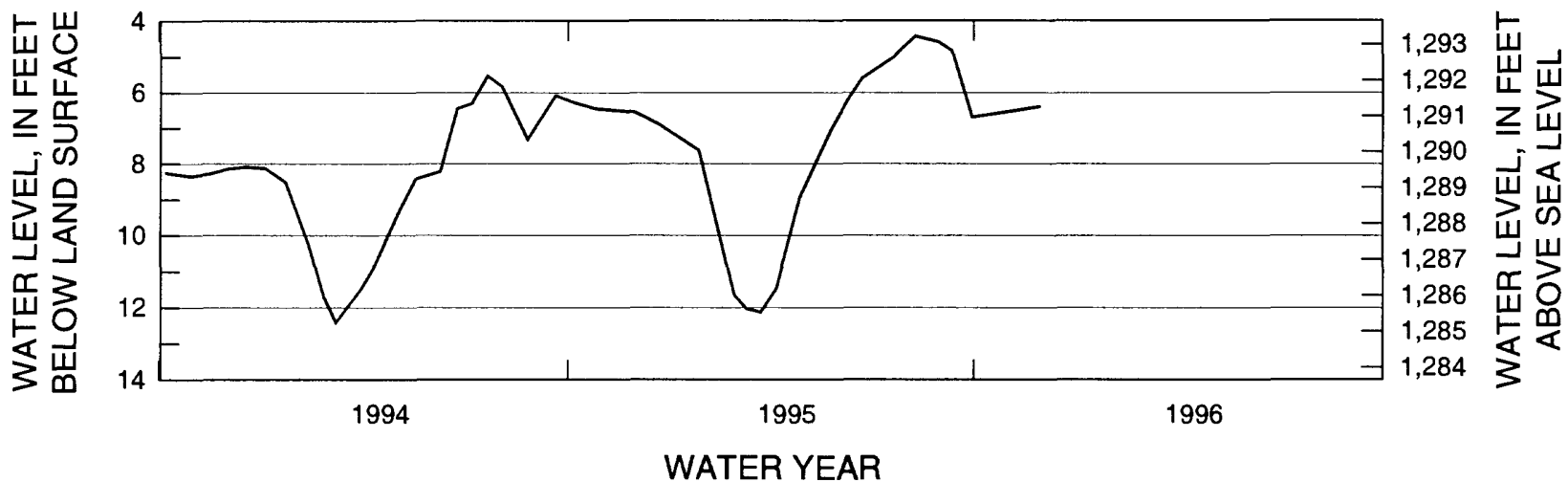

WATER YEAR

Figure 48. Hydrograph for observation well 110N62W9BBBC7, CO-38-90, water years 1994-96.

LOCAL WELL NUMBER: 110N62W9BBBD

SITE IDENTIFIER: 442117098173601

OTHER IDENTIFIER: CO-45-90

ALTITUDE OF LAND SURFACE: $1,297.66$ feet

MEASURING POINT: 2.39 feet above land surface

AQUIFER: Warren

PERIOD OF RECORD: November 6, 1990, to November 29, 1995

EXTREMES FOR PERIOD SHOWN: Highest, 6.47 feet, September 11, 1995; lowest, 27.24 feet, March 3, 1994. EXTREMES FOR PERIOD OF RECORD: Highest, 6.47 feet, September 11, 1995; lowest, 36.17 feet,

November 6, 1990.

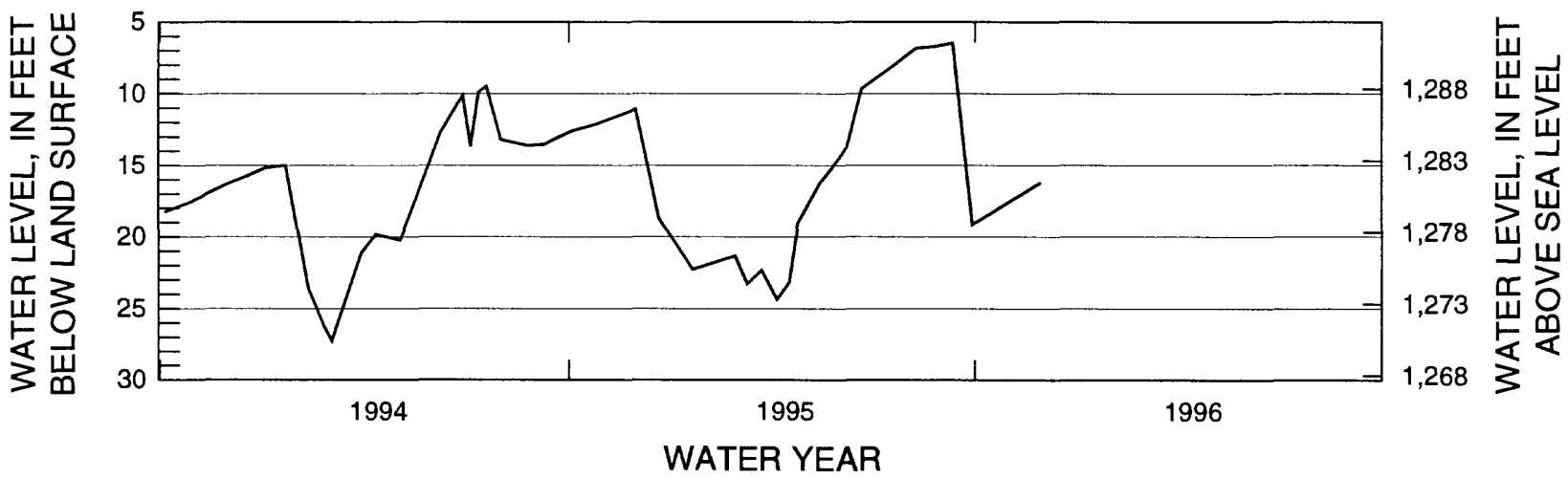

Figure 49. Hydrograph for observation well 110N62W9BBBD, C0-45-90, water years 1994-96. 
LOCAL WELL NUMBER: 110N62W9BBBD3

SITE IDENTIFIER: 442117098173603

OTHER IDENTIFIER: CO-47-90

ALTITUDE OF LAND SURFACE: $1,297.66$ feet

MEASURING POINT: 2.31 feet above land surface

AQUIFER: Warren

PERIOD OF RECORD: November 6, 1990, to October 25, 1994

EXTREMES FOR PERIOD SHOWN: Highest, 9.61 feet, July 20, 1994; lowest, 27.96 feet, March 11, 1994. EXTREMES FOR PERIOD OF RECORD: Highest, 9.61 feet, July 20, 1994; lowest, 36.16 feet, February 1, 1991.
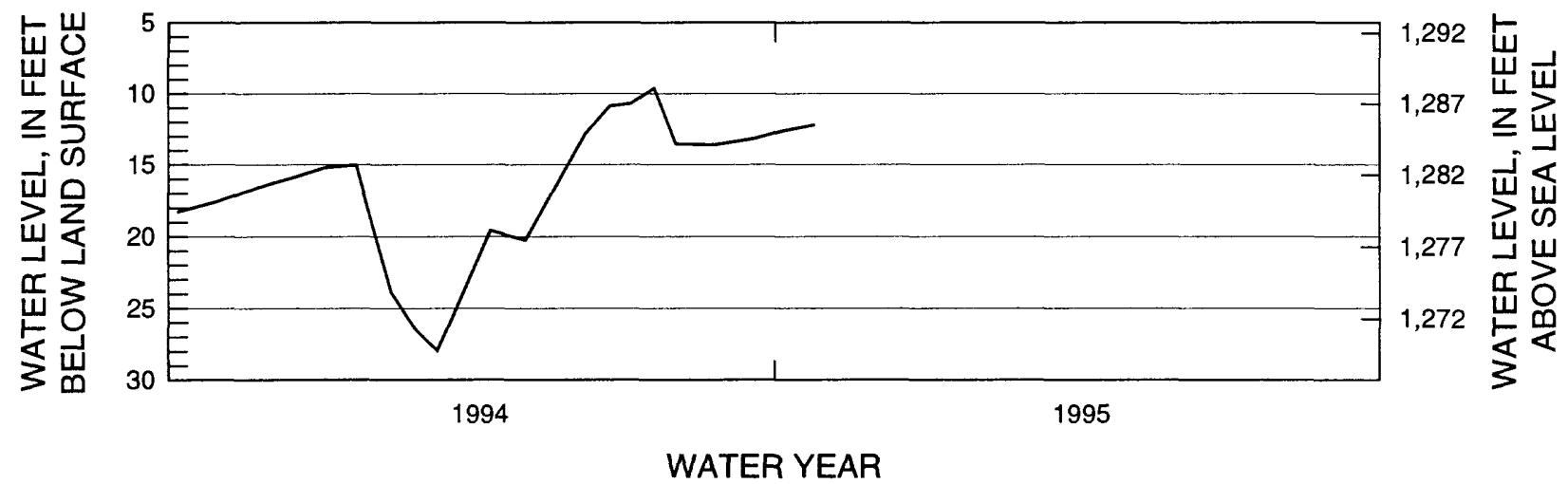

WATER YEAR

Figure 50. Hydrograph for observation well 110N62W9BBBD3, CO-47-90, water years 1994-95.

LOCAL WELL NUMBER: 110N62W9BBBD4

SITE IDENTIFIER: 442117098173604

OTHER IDENTIFIER: CO-48-90

ALTITUDE OF LAND SURFACE: $1,297.66$ feet

MEASURING POINT: 2.21 feet above land surface

AQUIFER: Warren

PERIOD OF RECORD: November 6, 1990, to October 25, 1994

EXTREMES FOR PERIOD SHOWN: Highest, 9.52 feet, July 20, 1994; lowest, 27.99 feet, March 11, 1994.

EXTREMES FOR PERIOD OF RECORD: Highest, 9.52 feet, July 20, 1994; lowest, 36.19 feet, November 6, 1990.
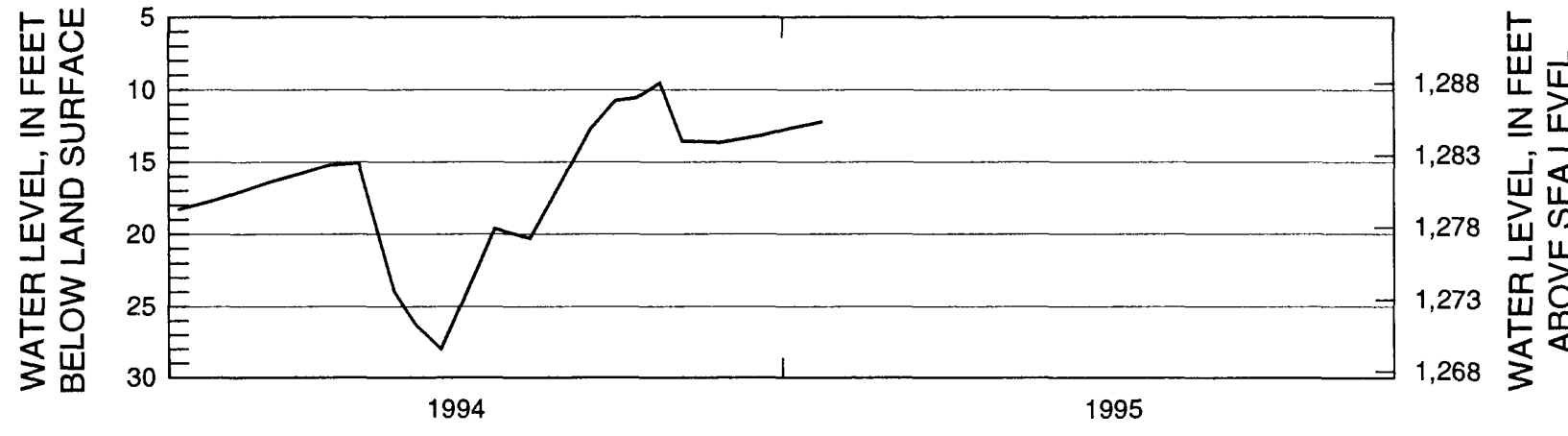

WATER YEAR

Figure 51. Hydrograph for observation well 110N62W9BBBD4, CO-48-90, water years 1994-95. 
LOCAL WELL NUMBER: 110N62W9BBBD5

SITE IDENTIFIER: 442117098173501

OTHER IDENTIFIER: CO-49-90

ALTITUDE OF LAND SURFACE: $1,297.08$ feet

MEASURING POINT: 3.53 feet above land surface

AQUIFER: Warren

PERIOD OF RECORD: November 6, 1990, to October 25, 1994

EXTREMES FOR PERIOD SHOWN: Highest, 9.31 feet, July 20, 1994; lowest, 27.40 feet, March 11, 1994.

EXTREMES FOR PERIOD OF RECORD: Highest, 9.31 feet, July 20, 1994; lowest, 36.29 feet, November 21, 1990.
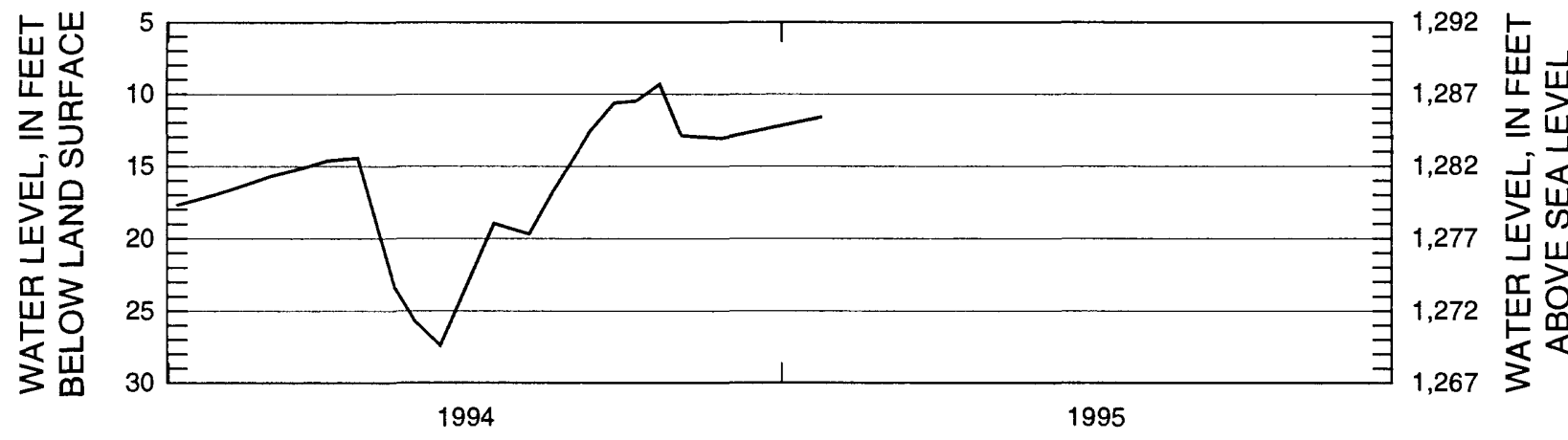

WATER YEAR

Figure 52. Hydrograph for observation well 110N62W9BBBD5, CO-49-90, water years 1994-95.

LOCAL WELL NUMBER: 110N62W9BBBD6

SITE IDENTIFIER: 442117098173502

OTHER IDENTIFIER: CO-50-90

ALTITUDE OF LAND SURFACE: $1,297.08$ feet

MEASURING POINT: 3.06 feet above land surface

AQUIFER: Warren

PERIOD OF RECORD: November 6, 1990, to November 29, 1995

EXTREMES FOR PERIOD SHOWN: Highest, 6.09 feet, September 11, 1995; lowest, 25.87 feet, March 7, 1994.

EXTREMES FOR PERIOD OF RECORD: Highest, 6.09 feet, September 11, 1995, lowest, 36.22 feet,

November 6, 1990.
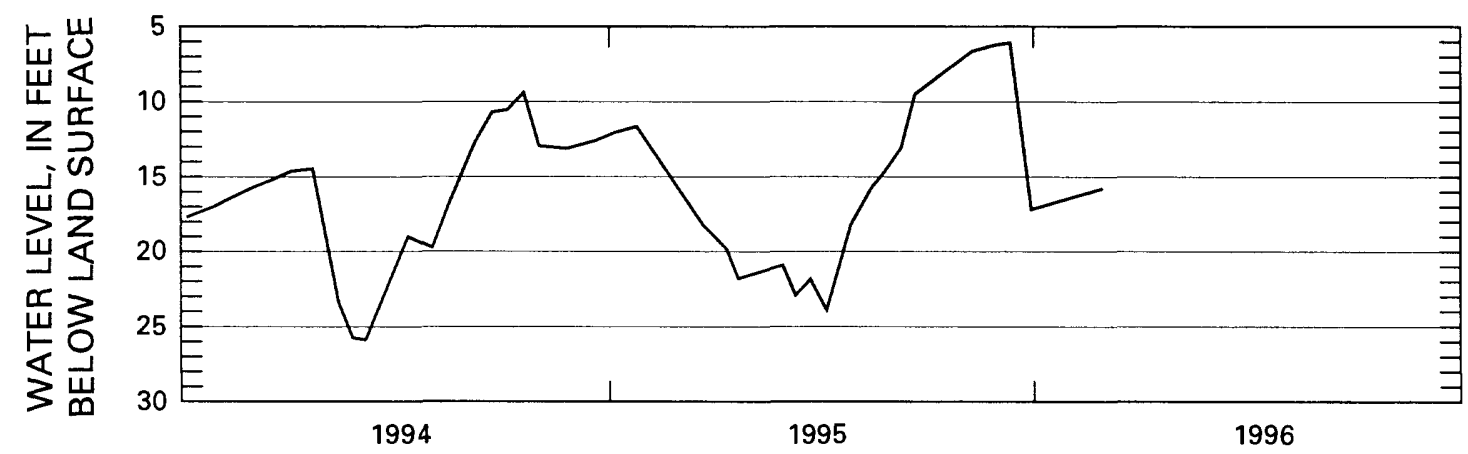

1,292

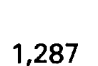

出山

WATER YEAR

Figure 53. Hydrograph for observation well 110N62W9BBBD6, CO-50-90, water years 1994-96. 
LOCAL WELL NUMBER: 110N62W9BBBD7

SITE IDENTIFIER: 442117098173503

OTHER IDENTIFIER: CO-51-90

ALTITUDE OF LAND SURFACE: $1,297.08$ feet

MEASURING POINT: 2.98 feet above land surface

AQUIFER: Warren

PERIOD OF RECORD: November 6, 1990, to October 25, 1994

EXTREMES FOR PERIOD SHOWN: Highest, 9.38 feet, July 20, 1994; lowest, 27.40 feet, March 11, 1994.

EXTREMES FOR PERIOD OF RECORD: Highest, 9.38 feet, July 20, 1994; lowest, 36.31 feet, November 21, 1990.
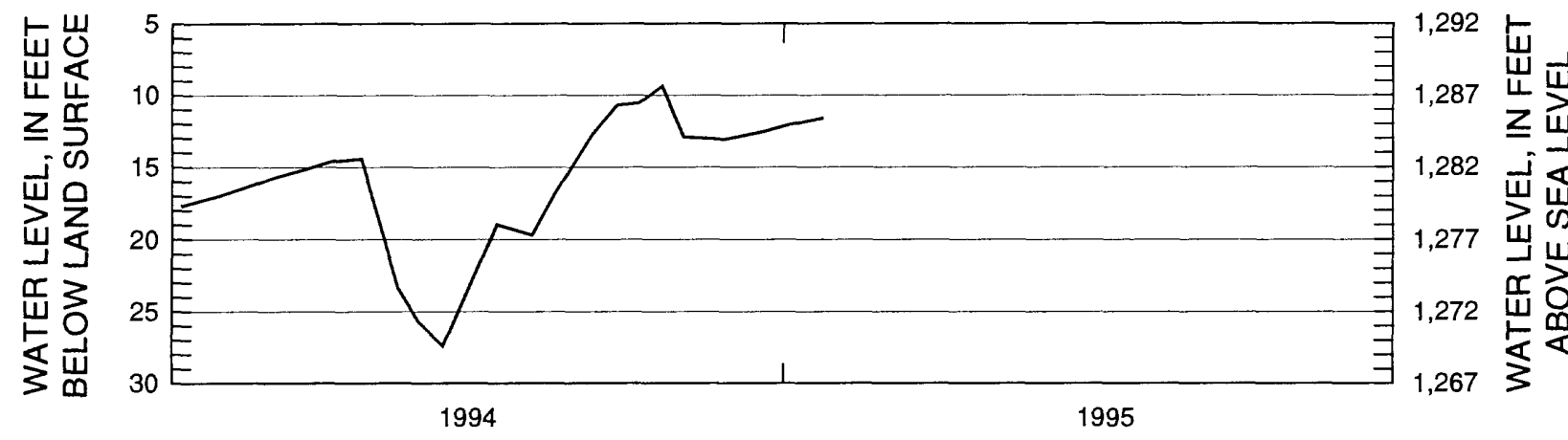

WATER YEAR

Figure 54. Hydrograph for observation well 110N62W9BBBD7, CO-51-90, water years 1994-95.

LOCAL WELL NUMBER: 110N62W9BBCA

SITE IDENTIFIER: 442115098173501

OTHER IDENTIFIER: CO-52-90

ALTITUDE OF LAND SURFACE: $1,295.37$ feet

MEASURING POINT: 2.90 feet above land surface

AQUIFER: Warren

PERIOD OF RECORD: November 6, 1990, to October 25, 1994

EXTREMES FOR PERIOD SHOWN: Highest, 7.96 feet, July 28, 1994; lowest, 26.46 feet, March 11, 1994.

EXTREMES FOR PERIOD OF RECORD: Highest, 7.96 feet, July 28, 1994; lowest, 35.15 feet, November 21, 1990.
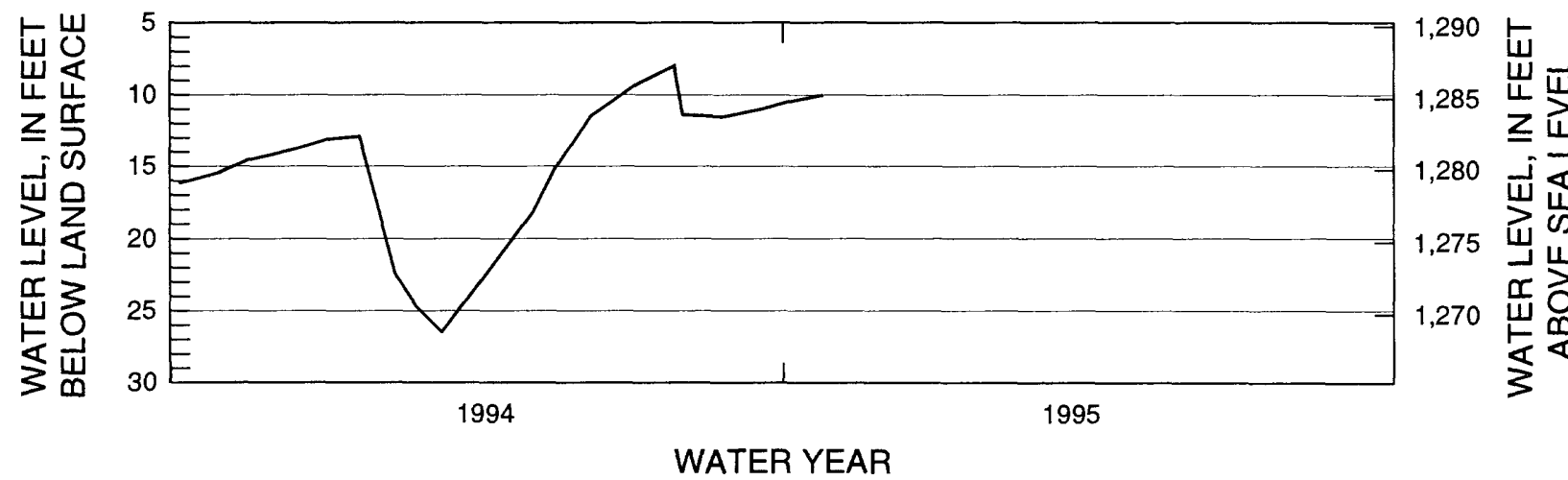

Figure 55. Hydrograph for observation well 110N62W9BBCA, CO-52-90, water years 1994-95. 
LOCAL WELL NUMBER: 110N62W9BBCA2

SITE IDENTIFIER: 442115098173502

OTHER IDENTIFIER: CO-53-90

ALTITUDE OF LAND SURFACE: $1,295.37$ feet

MEASURING POINT: 2.34 feet above land surface

AQUIFER: Warren

PERIOD OF RECORD: November 6, 1990, to November 29, 1995

EXTREMES FOR PERIOD SHOWN: Highest, 4.55 feet, September 11, 1995; lowest, 26.46 feet, March 11, 1994.

EXTREMES FOR PERIOD OF RECORD: Highest, 4.55 feet, September 11, 1995; lowest 35.19 feet, November 21, 1990.
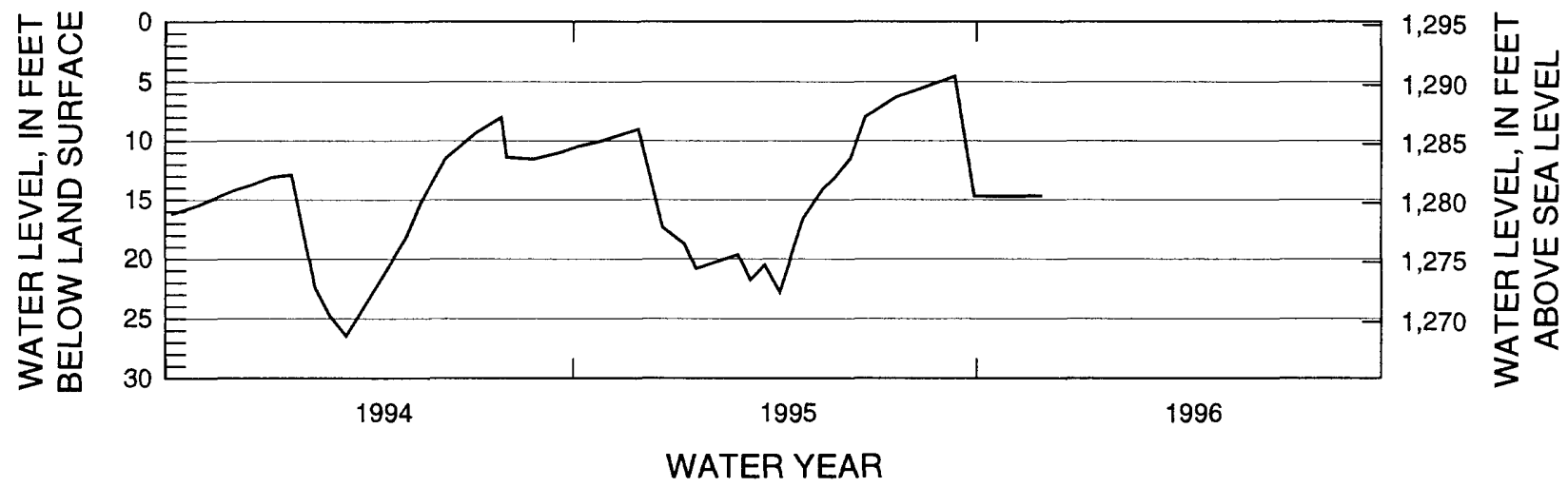

Figure 56. Hydrograph for observation well 110N62W9BBCA2, CO-53-90, water years 1994-96.

LOCAL WELL NUMBER: 110N62W9BBCA3

SITE IDENTIFIER: 442115098173503

OTHER IDENTIFIER: CO-54-90

ALTITUDE OF LAND SURFACE: $1,295.37$ feet

MEASURING POINT: 2.55 feet above land surface

AQUIFER: Warren

PERIOD OF RECORD: November 6, 1990, to October 25, 1994

EXTREMES FOR PERIOD SHOWN: Highest, 8.06 feet, July 29, 1994; lowest, 26.48 feet, March 11, 1994.

EXTREMES FOR PERIOD OF RECORD: Highest, 8.06 feet, July 29, 1994; lowest, 35.25 feet, November 21, 1990.
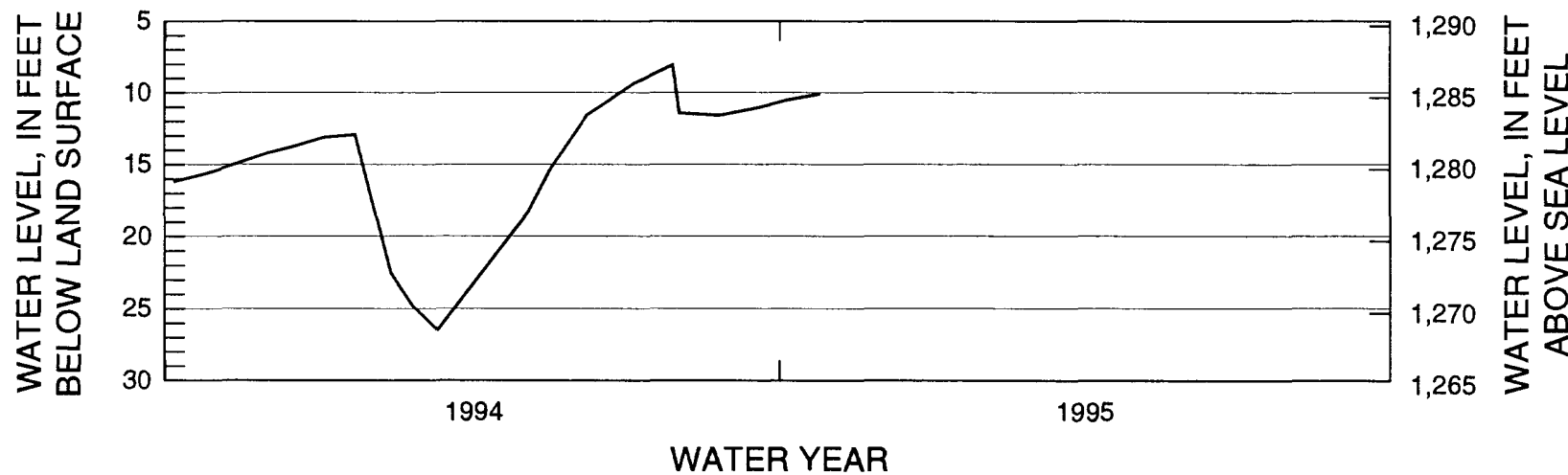

WATER YEAR

Figure 57. Hydrograph for observation well 110N62W9BBCA3, CO-54-90, water years 1994-95. 
LOCAL WELL NUMBER: 110N62W9BBCB

SITE IDENTIFIER: 442111098173801

OTHER IDENTIFIER: CO-18-90

ALTITUDE OF LAND SURFACE: $1,295.87$ feet

MEASURING POINT: 2.71 feet above land surface

AQUIFER: Warren

PERIOD OF RECORD: August 15, 1990, to November 29, 1995

EXTREMES FOR PERIOD SHOWN: Highest, 5.26 feet, September 11, 1995; lowest, 26.68 feet, February 24, 1994.

EXTREMES FOR PERIOD OF RECORD: Highest, 5.26 feet, September 11, 1995; lowest, 36.50 feet, November 21, 1990.
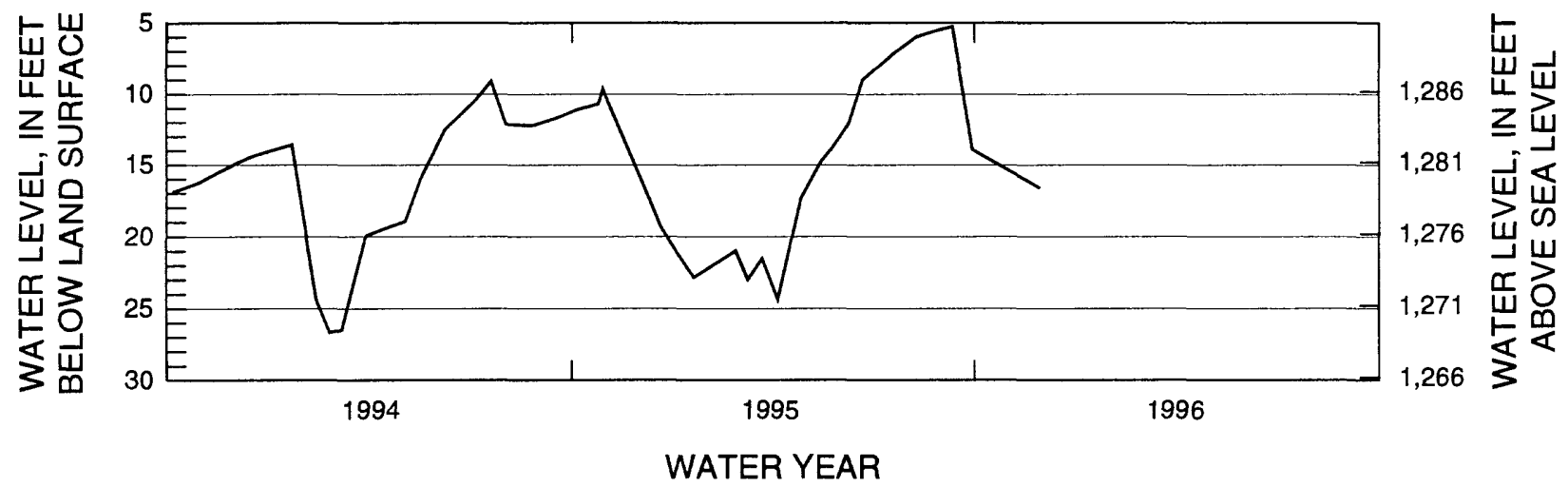

Figure 58. Hydrograph for observation well 110N62W9BBCB, CO-18-90, water years 1994-96.

LOCAL WELL NUMBER: 110N62W9BBCB2

SITE IDENTIFIER: 442117098174002

OTHER IDENTIFIER: CO-39-90

ALTITUDE OF LAND SURFACE: $1,297.65$ feet

MEASURING POINT: 3.32 feet above land surface

AQUIFER: Warren

PERIOD OF RECORD: November 6, 1990, to October 25, 1994

EXTREMES FOR PERIOD SHOWN: Highest, 10.30 feet, July 6, 1994; lowest, 28.45 feet, March 11, 1994.

EXTREMES FOR PERIOD OF RECORD: Highest, 10.30 feet, July 6, 1994; lowest, 37.27 feet, November 6, 1990.
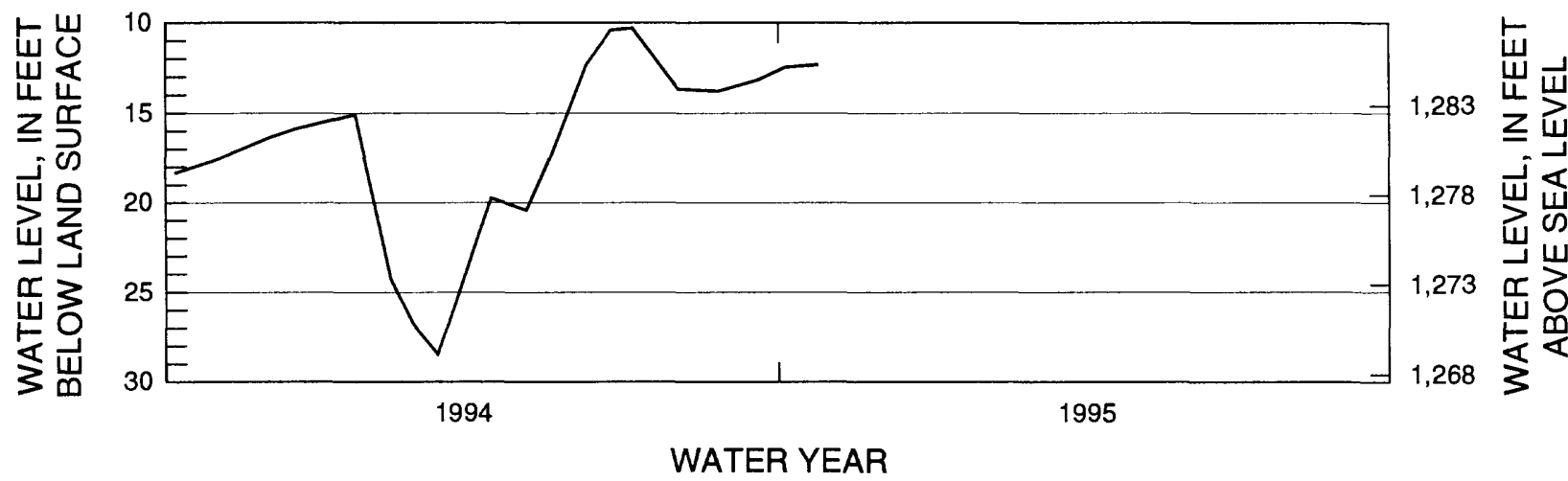

WATER YEAR

Figure 59. Hydrograph for observation well 110N62W9BBCB2, CO-39-90, water years 1994-95. 
LOCAL WELL NUMBER: 110N62W9BBCB3

SITE IDENTIFIER: 442117098174003

OTHER IDENTIFIER: CO-40-90

ALTITUDE OF LAND SURFACE: $1,297.65$ feet

MEASURING POINT: 2.69 feet above land surface

AQUIFER: Warren

PERIOD OF RECORD: November 6, 1990, to October 25, 1994

EXTREMES FOR PERIOD SHOWN: Highest, 9.17 feet, July 20, 1994; lowest, 28.36 feet, March 11, 1994.

EXTREMES FOR PERIOD OF RECORD: Highest, 9.17 feet, July 20, 1994; lowest, 37.05 feet, November 6, 1990.

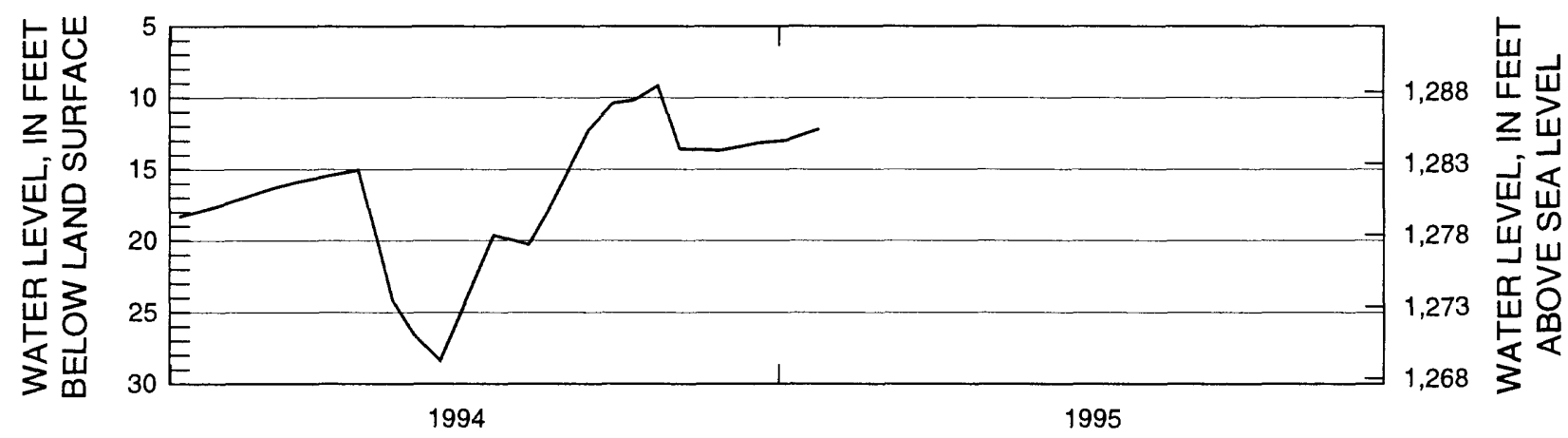

WATER YEAR

Figure 60. Hydrograph for observation well 110N62W9BBCB3, CO-40-90, water years 1994-95.

LOCAL WELL NUMBER: 110N62W9BBCB4

SITE IDENTIFIER: 442117098174004

OTHER IDENTIFIER: CO-41-90

ALTITUDE OF LAND SURFACE: $1,297.65$ feet

MEASURING POINT: 2.67 feet above land surface

AQUIFER: Till

PERIOD OF RECORD: November 6, 1990, to November 29, 1995

EXTREMES FOR PERIOD SHOWN: Highest, 3.33 feet, August 9, 1995; lowest, 25.79 feet, February 24, 1994.

EXTREMES FOR PERIOD OF RECORD: Highest, 3.33 feet, August 9, 1995; lowest, 35.64 feet, February 1, 1991.
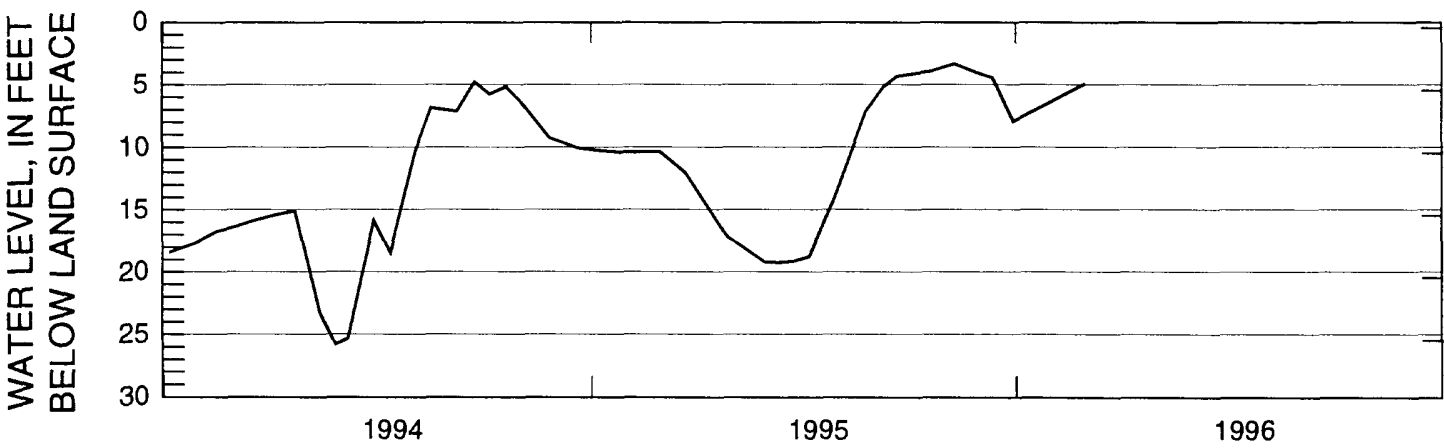

1996

WATER YEAR

Figure 61. Hydrograph for observation well 110N62W9BBCB4, CO-41-90, water years 1994-96. 
LOCAL WELL NUMBER: 110N62W9BBCB5

SITE IDENTIFIER: 442117098174005

OTHER IDENTIFIER: CO-42-90

ALTITUDE OF LAND SURFACE: $1,297.65$ feet

MEASURING POINT: 2.59 feet above land surface

AQUIFER: Till

PERIOD OF RECORD: November 6, 1990, to November 29, 1995

EXTREMES FOR PERIOD SHOWN: Highest, 3.22 feet, August 9, 1995; lowest, 10.15 feet, March 7, 1994. EXTREMES FOR PERIOD OF RECORD: Highest, 3.22 feet, August 9, 1995; lowest, 16.23 feet, April 15, 1991.
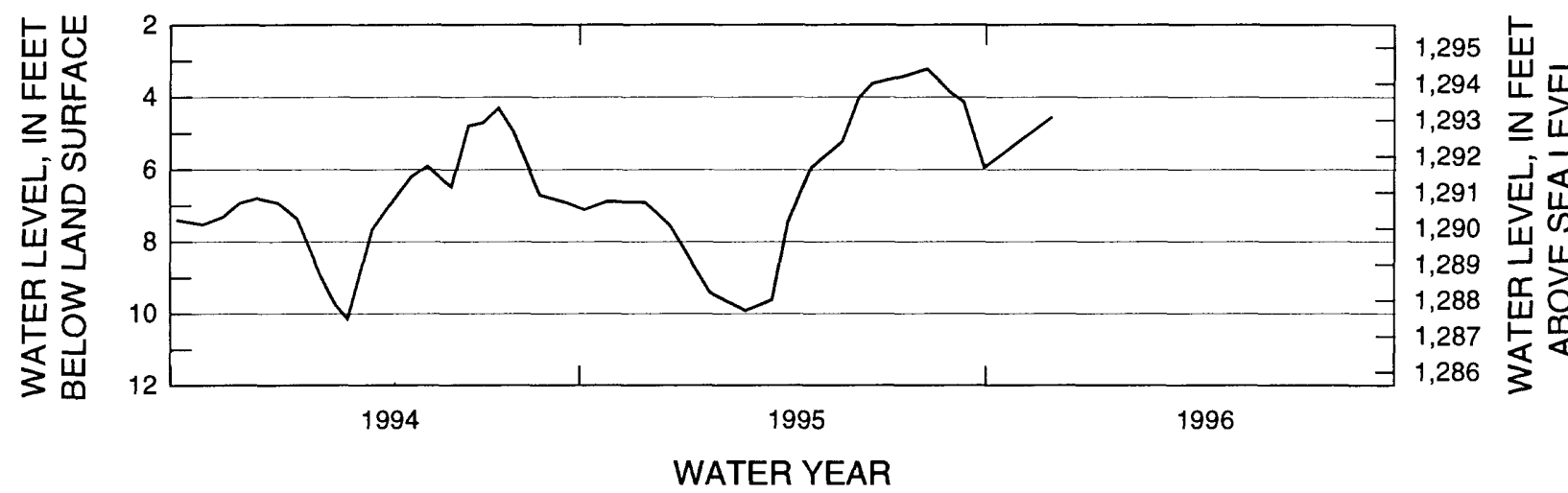

Figure 62. Hydrograph for observation well 110N62W9BBCB5, CO-42-90, water years 1994-96.

LOCAL WELL NUMBER: 110N62W9BBCB6

SITE IDENTIFIER: 442117098174006

OTHER IDENTIFIER: CO-43-90

ALTITUDE OF LAND SURFACE: 1297.65 feet

MEASURING POINT: 3.32 feet above land surface

AQUIFER: Till

PERIOD OF RECORD: November 6, 1990, to November 27, 1995

EXTREMES FOR PERIOD SHOWN: Highest, 0.82 feet, June 9, 1995; lowest, 6.22 feet, February 27, 1995.

EXTREMES FOR PERIOD OF RECORD: Highest, 0.60 feet, June 6, 1991; lowest, 9.70 feet, April 1, 1991.
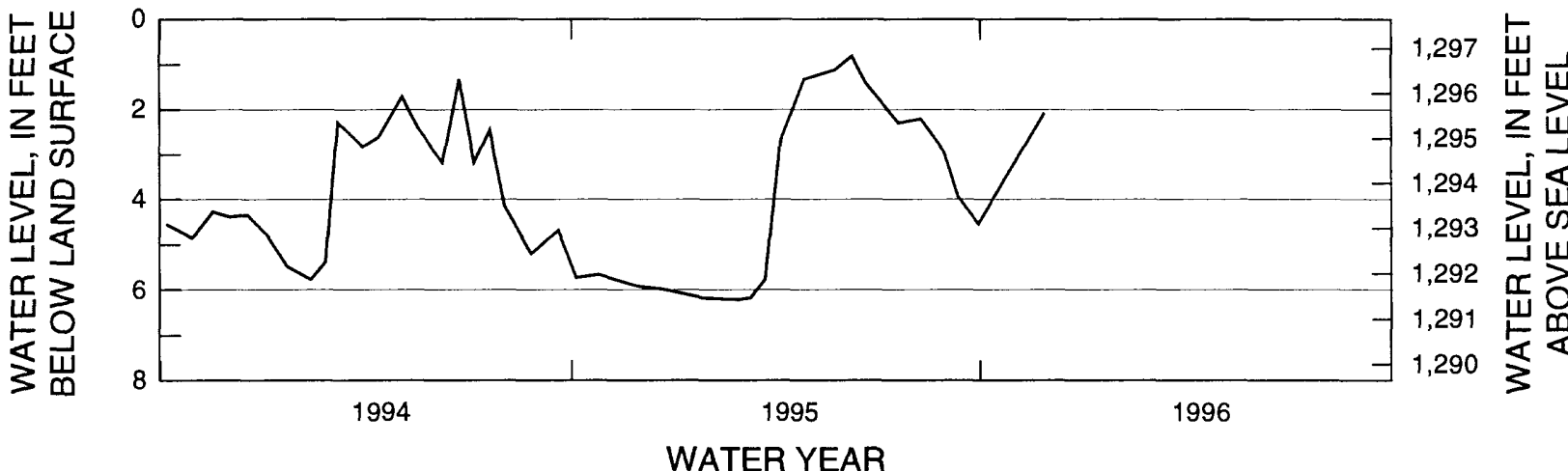

Figure 63. Hydrograph for observation well 110N62W9BBCB6, CO-43-90, water years 1994-96. 
LOCAL WELL NUMBER: 110N62W9BBCB7

SITE IDENTIFIER: 442117098174007

OTHER IDENTIFIER: CO-44-90

ALTITUDE OF LAND SURFACE: $1,297.65$ feet

MEASURING POINT: 2.91 feet above land surface

AQUIFER: Till

PERIOD OF RECORD: November 6, 1990, to November 29, 1995

EXTREMES FOR PERIOD SHOWN: Highest, 0.81 feet; June 9, 1995; lowest, 6.22 feet, February 27, 1995. EXTREMES FOR PERIOD OF RECORD: Highest, 0.55 feet, June 6, 1991; lowest, 9.70 feet, April 1, 1991.

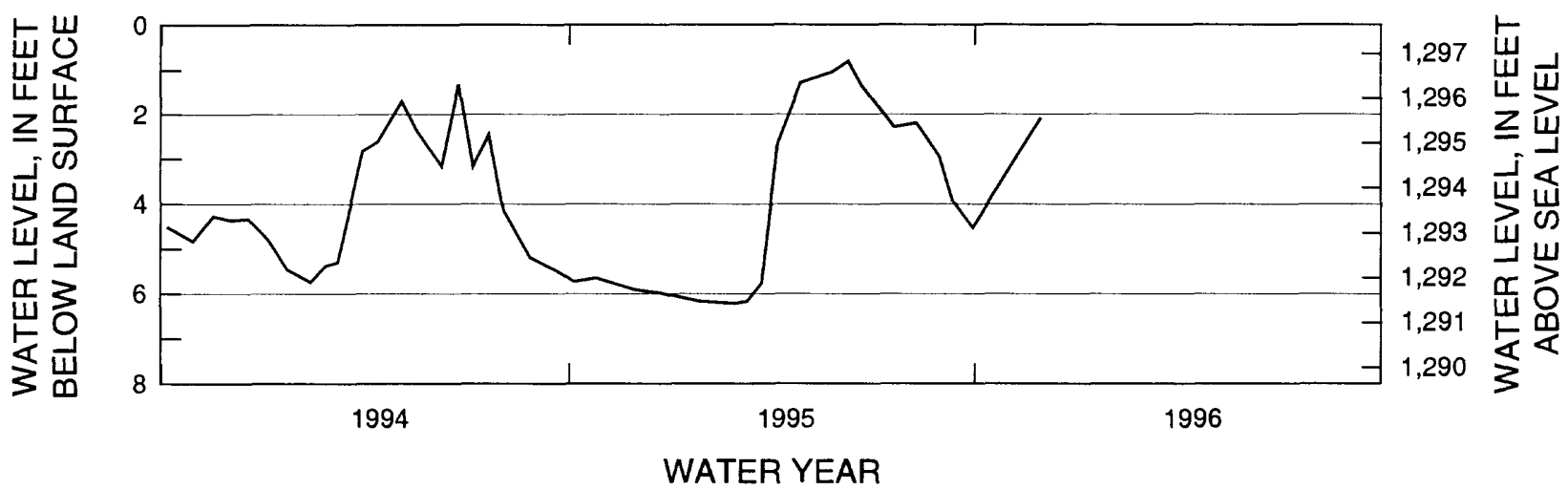

Figure 64. Hydrograph for observation well 110N62W9BBCB7, CO-44-90, water years 1994-96.

LOCAL WELL NUMBER: 110N62W9BBCB8

SITE IDENTIFIER: 442117098174001

OTHER IDENTIFIER: CO-17-90

ALTITUDE OF LAND SURFACE: $1,297.65$ feet

MEASURING POINT: 2.81 feet above land surface

AQUIFER: Warren

PERIOD OF RECORD: August 15, 1990, to November 29, 1995

EXTREMES FOR PERIOD SHOWN: Highest 6.09 feet, September 13, 1995; lowest, 28.64 feet, March 16, 1994.

EXTREMES FOR PERIOD OF RECORD: Highest, 6.09 feet, September 13, 1995; lowest 36.70 feet, November 21, 1990.

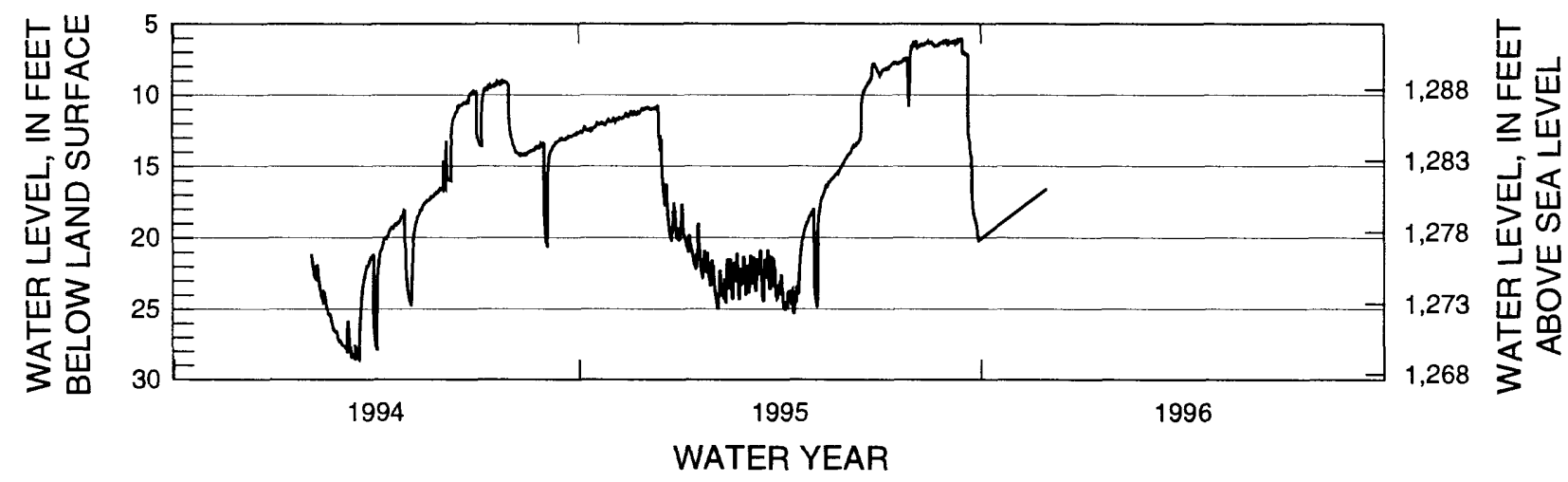

Figure 65. Hydrograph for observation well 110N62W9BBCB8, CO-17-90, water years 1994-96. 
LOCAL WELL NUMBER: 110N62W9BBCB9

SITE IDENTIFIER: 442115098174202

OTHER IDENTIFIER: CO-63-90

ALTITUDE OF LAND SURFACE: $1,298.24$ feet

MEASURING POINT: 2.81 feet above land surface

AQUIFER: Warren

PERIOD OF RECORD: November 5, 1990, to October 25, 1994

EXTREMES FOR PERIOD SHOWN: Highest, 10.17 feet, July 20, 1994; lowest, 27.69 feet, March 3, 1994.

EXTREMES FOR PERIOD OF RECORD: Highest, 10.17 feet, July 20, 1994; lowest, 36.79 feet, November 21, 1990.
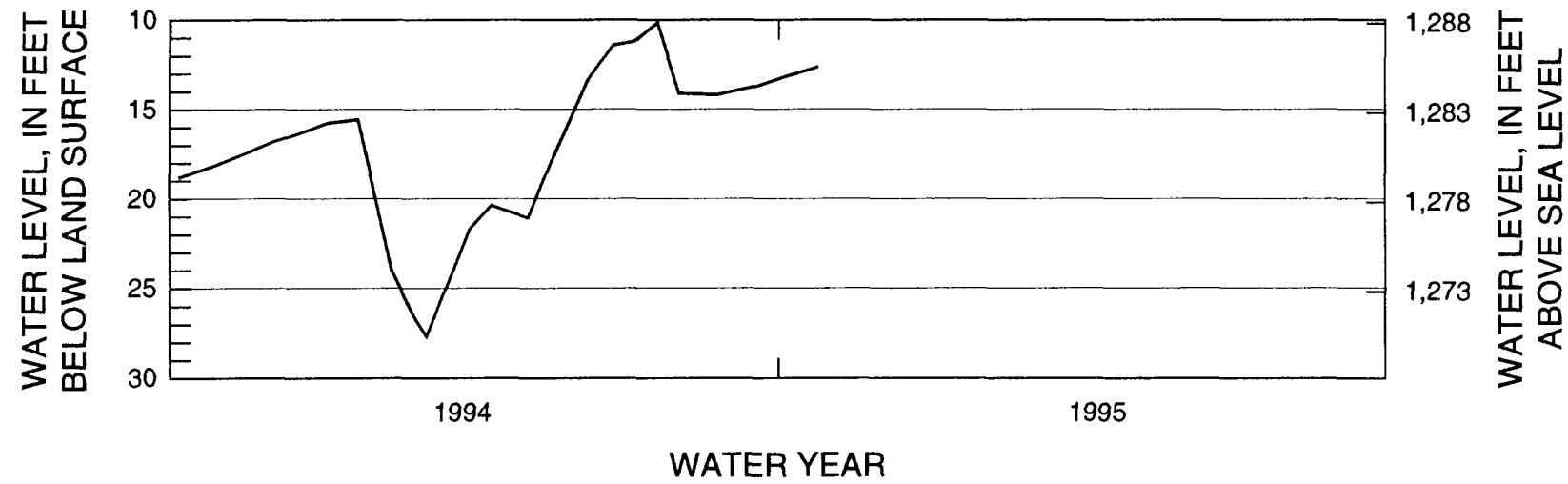

Figure 66. Hydrograph for observation well 110N62W9BBCB9, CO-63-90, water years 1994-95.

LOCAL WELL NUMBER: 110N62W9BBCB10

SITE IDENTIFIER: 442115098174203

OTHER IDENTIFIER: CO-64-90

ALTITUDE OF LAND SURFACE: $1,298.24$ feet

MEASURING POINT: 2.44 feet above land surface

AQUIFER: Warren

PERIOD OF RECORD: November 5, 1990, to October 25, 1994

EXTREMES FOR PERIOD SHOWN: Highest, 10.12 feet, July 20, 1994; lowest, 28.31 feet, March 11, 1994.

EXTREMES FOR PERIOD OF RECORD: Highest, 10.12 feet, July 20, 1994; lowest, 38.80 feet, November 21, 1990.
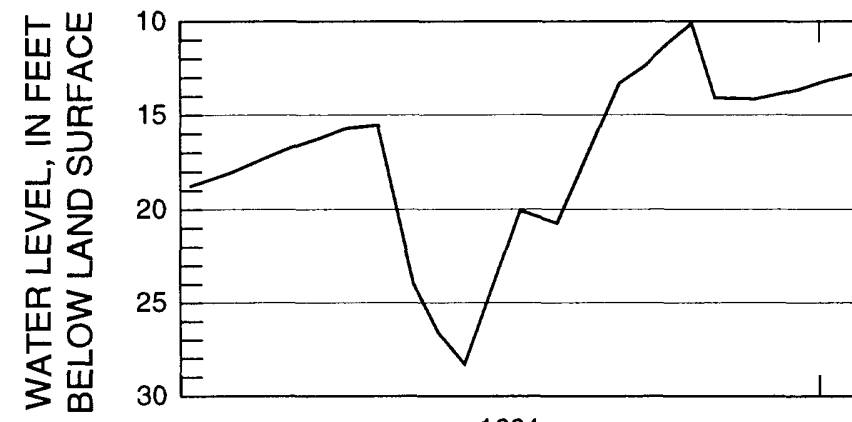

1994

WATER YEAR

Figure 67. Hydrograph for observation well 110N62W9BBCB10, CO-64-90, water years 1994-95. 
LOCAL WELL NUMBER: 110N62W9BBCB11

SITE IDENTIFIER: 442115098174201

OTHER IDENTIFIER: CO-62-90

ALTITUDE OF LAND SURFACE: $1,297.30$ feet

MEASURING POINT: 3.11 feet above land surface

AQUIFER: Warren

PERIOD OF RECORD: November 5, 1990, to November 29, 1995

EXTREMES FOR PERIOD SHOWN: Highest, 7.04 feet, September 11, 1995; lowest, 28.32 feet, March 11, 1994.

EXTREMES FOR PERIOD OF RECORD: Highest, 7.04 feet, September 11, 1995; lowest, 37.25 feet,

November 21, 1990.
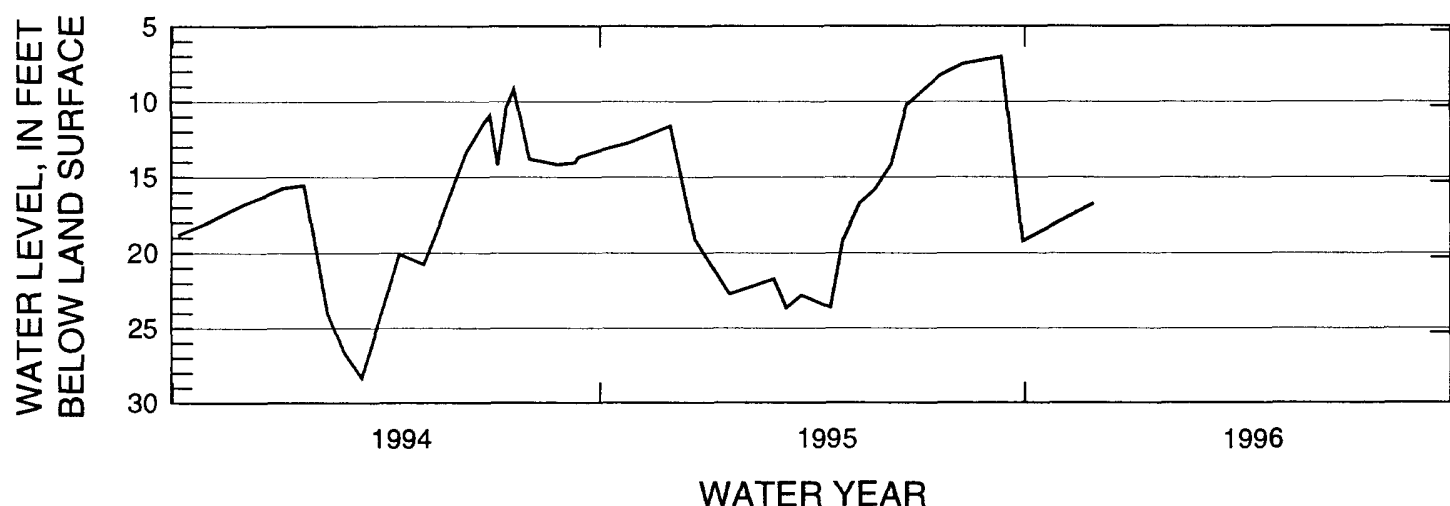

1,292

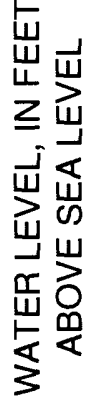

WATER YEAR

Figure 68. Hydrograph for observation well 110N62W9BBCB11, CO-62-90, water years 1994-96.

LOCAL WELL NUMBER: 110N62W9BBCB12

SITE IDENTIFIER: 442115098173902

OTHER IDENTIFIER: CO-57-90

ALTITUDE OF LAND SURFACE: $1,295.82$ feet

MEASURING POINT: 2.60 feet above land surface

AQUIFER: Warren

PERIOD OF RECORD: November 5, 1990, to October 25, 1994

EXTREMES FOR PERIOD SHOWN: Highest, -0.11 feet, May 3, 1994; lowest, 7.31 feet, August 26, 1994.

EXTREMES FOR PERIOD OF RECORD: Highest, -0.11 feet, May 3, 1994; lowest, 37.38 feet, November 21, 1990.
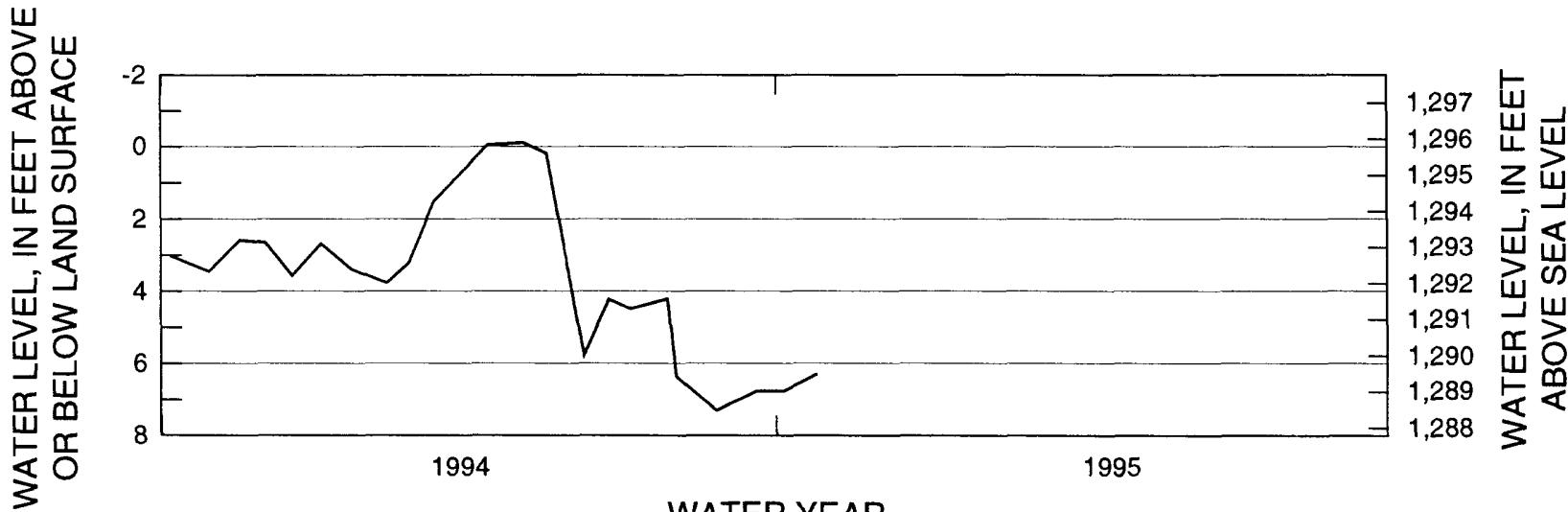

WATER YEAR

Figure 69. Hydrograph for observation well 110N62W9BBCB12, C0-57-90, water years 1994-95. 
LOCAL WELL NUMBER: 110N62W9BBCB13

SITE IDENTIFIER: 442115098173903

OTHER IDENTIFIER: CO-58-90

ALTITUDE OF LAND SURFACE: $1,295.82$ feet

MEASURING POINT: 2.58 feet above land surface

AQUIFER: Warren

PERIOD OF RECORD: November 5, 1990, to October 25, 1994

EXTREMES FOR PERIOD SHOWN: Highest, 8.22 feet, July 28, 1994; lowest, 27.10 feet, March 11, 1994.

EXTREMES FOR PERIOD OF RECORD: Highest, 8.22 feet, July 28, 1994; lowest, 35.55 feet, November 21, 1990.
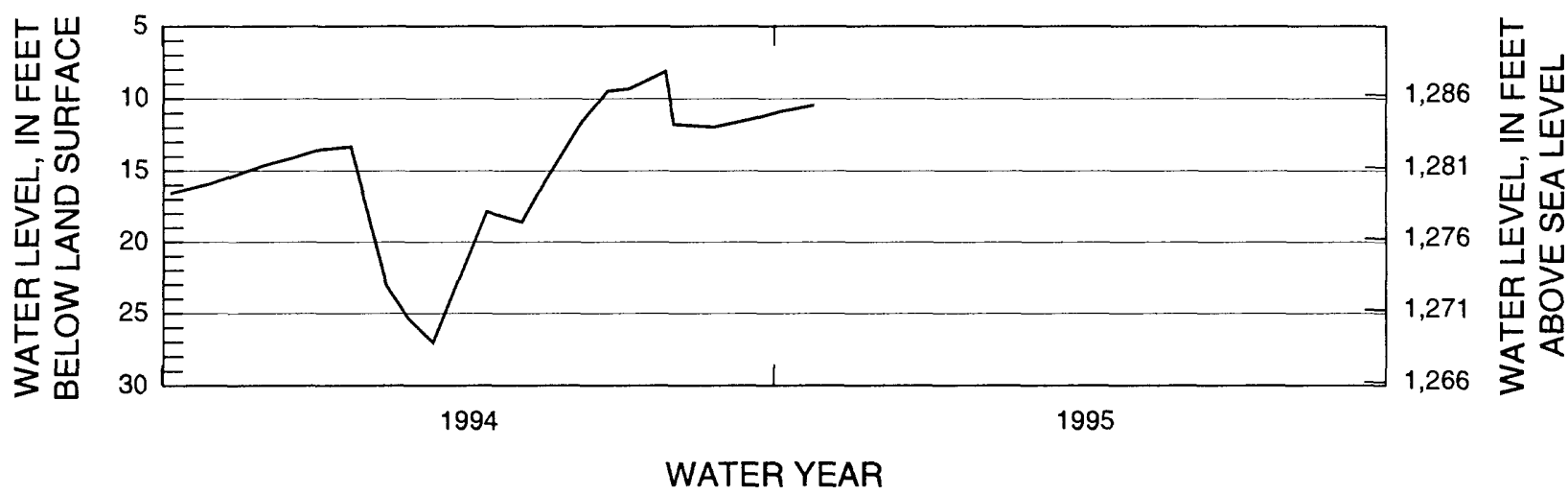

Figure 70. Hydrograph for observation well 110N62W9BBCB13, CO-58-90, water years 1994-95.

LOCAL WELL NUMBER: 110N62W9BBCB14

SITE IDENTIFIER: 442115098173901

OTHER IDENTIFIER: CO-56-90

ALTITUDE OF LAND SURFACE: $1,295.82$ feet

MEASURING POINT: 2.59 feet above land surface

AQUIFER: Warren

PERIOD OF RECORD: November 5, 1990, to November 29, 1995

EXTREMES FOR PERIOD SHOWN: Highest, 4.85 feet, September 11, 1995; lowest, 26.87 feet, March 7, 1994.

EXTREMES FOR PERIOD OF RECORD: Highest, 4.85 feet, September 11, 1995; lowest, 35.49 feet,

November 21, 1990.

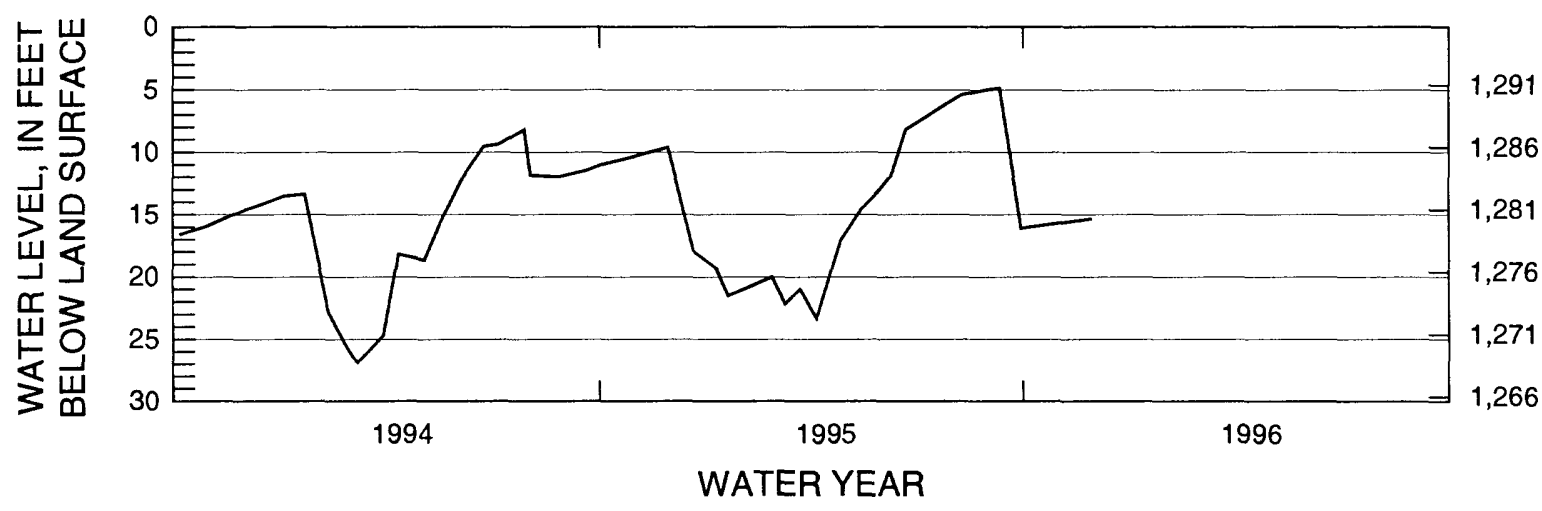

Figure 71. Hydrograph for obsenation well 110N62W9BBCB14, CO-56-90, water years 1994-96. 
LOCAL WELL NUMBER: 110N62W9BBCB15

SITE IDENTIFIER: 442117098174008

OTHER IDENTIFIER: Recharge well

ALTITUDE OF LAND SURFACE: 1298.40

MEASURING POINT: 1.56 feet above land surface

AQUIFER: Warren

PERIOD OF RECORD: January 21, 1994, to November 29, 1995

EXTREMES FOR PERIOD SHOWN: Highest, 0.61 feet, August 2, 1995; lowest, 41.38 feet, September 29, 1995.
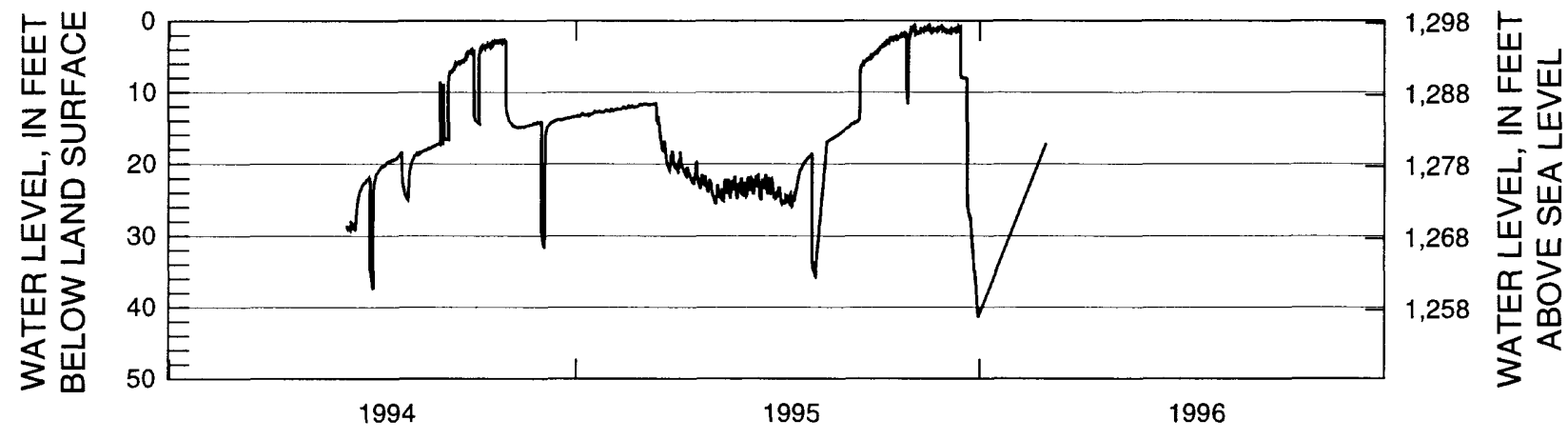

WATER YEAR

Figure 72. Hydrograph for recharge well 110N62W9BBCB15, water years 1994-96.

LOCAL WELL NUMBER: 110N62W9BBCC

SITE IDENTIFIER: 442113098174201

OTHER IDENTIFIER: CO-59-90

ALTITUDE OF LAND SURFACE: $1,297.30$ feet

MEASURING POINT: 2.85 feet above land surface

AQUIFER: Warren

PERIOD OF RECORD: November 5, 1990, to November 29, 1995

EXTREMES FOR PERIOD SHOWN: Highest, 6.06 feet, September 12, 1995; lowest, 28.04 feet, March 11, 1994.

EXTREMES FOR PERIOD OF RECORD: Highest, 6.06 feet, September 12, 1995; lowest, 36.51 feet, November 5, 1990, November 21, 1990.
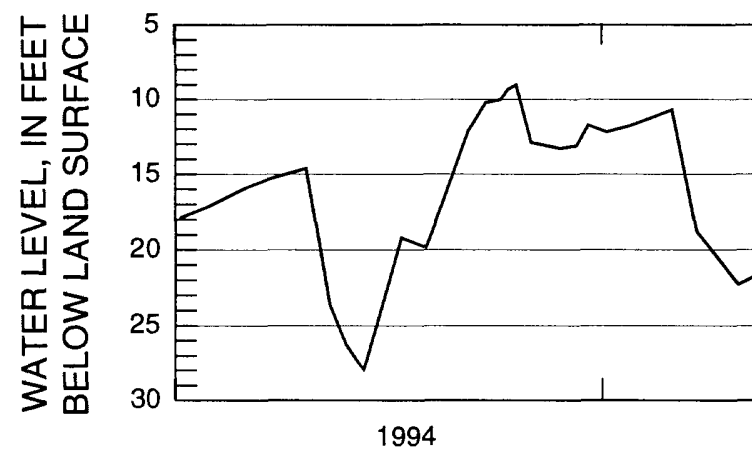

994
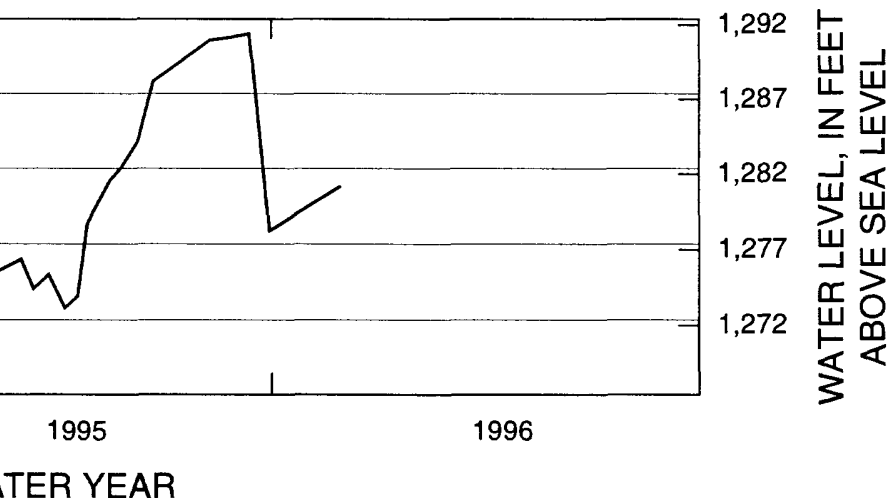

WATER YEAR

Figure 73. Hydrograph for observation well 110N62W9BBCC, CO-59-90, water years 1994-96. 
LOCAL WELL NUMBER: 110N62W9BBCC2

SITE IDENTIFIER: 442113098174202

OTHER IDENTIFIER: CO-60-90

ALTITUDE OF LAND SURFACE: $1,297.30$ feet

MEASURING POINT: 2.79 feet above land surface

AQUIFER: Warren

PERIOD OF RECORD: November 5, 1990, to October 25, 1994

EXTREMES FOR PERIOD SHOWN: Highest, 9.06 feet, July 20, 1994; lowest, 27.34 feet, March 3, 1994.

EXTREMES FOR PERIOD OF RECORD: Highest, 9.06 feet, July 20, 1994, lowest, 36.49 feet, November 21, 1990.

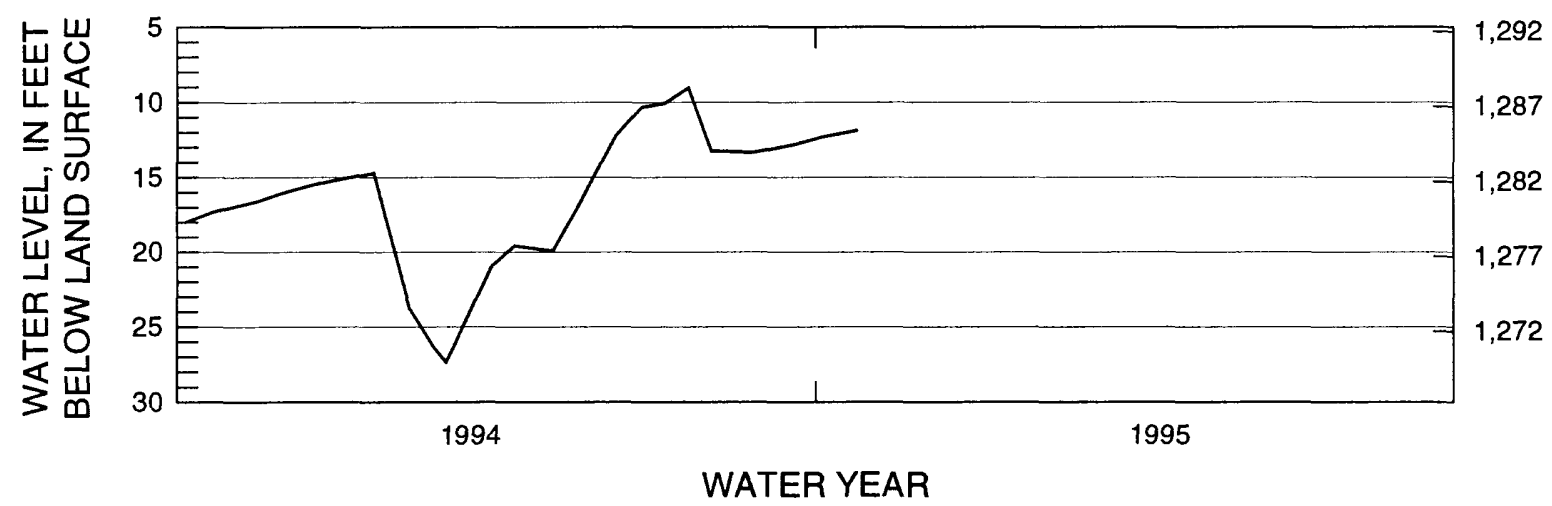

Figure 74. Hydrograph for observation well 110N62W9BBCC2, CO-60-90, water years 1994-95.

LOCAL WELL NUMBER: 110N62W9BBCC3

SITE IDENTIFIER: 442113098174203

OTHER IDENTIFIER: CO-61-90

ALTITUDE OF LAND SURFACE: $1,297.30$ feet

MEASURING POINT: 2.60 feet above land surface

AQUIFER: Warren

PERIOD OF RECORD: November 5, 1990, to October 25, 1994

EXTREMES FOR PERIOD SHOWN: Highest, 9.00 feet, July 20, 1994; lowest, 28.08 feet, March 11, 1994.

EXTREMES FOR PERIOD OF RECORD: Highest, 9.00 feet, July 20, 1994; lowest, 38.38 feet, November 21, 1990.
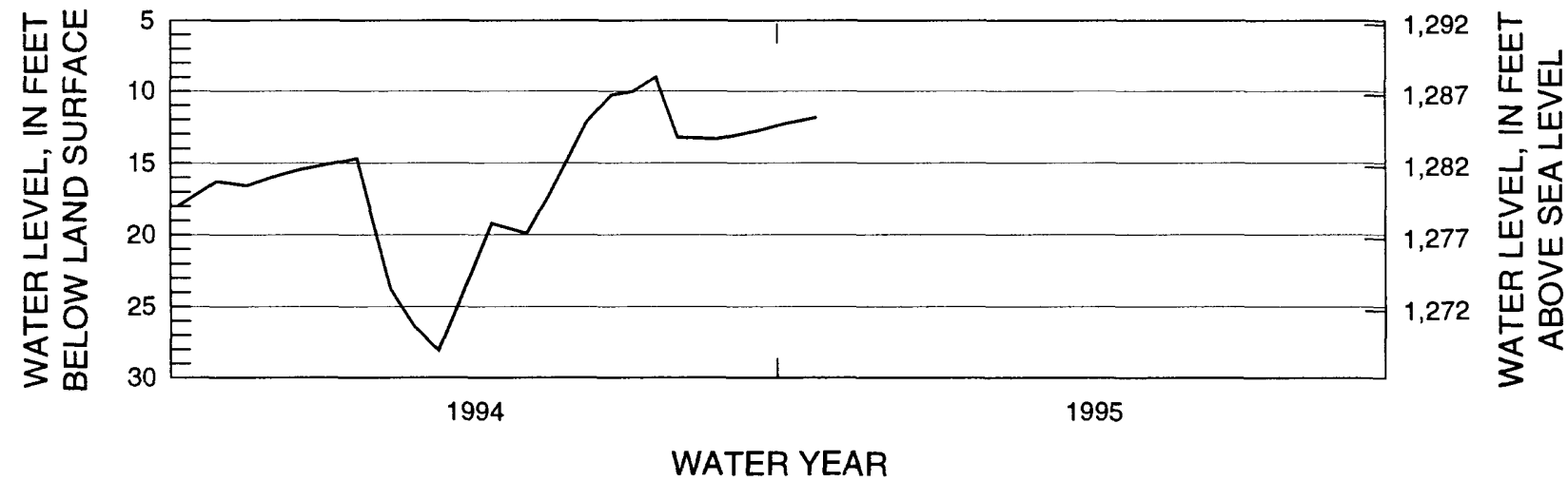

Figure 75. Hydrograph for observation well 110N62W9BBCC3, CO-61-90, water years 1994-95. 
LOCAL WELL NUMBER: 110N62W9BBCC4

SITE IDENTIFIER: 442113098174204

OTHER IDENTIFIER: A-05-90

ALTITUDE OF LAND SURFACE: $1,297.30$ feet

MEASURING POINT: 2.27 feet above land surface

AQUIFER: Till

PERIOD OF RECORD: November 5, 1990, to November 29, 1995

EXTREMES FOR PERIOD SHOWN: Highest, 1.55 feet, June 9, 1995; lowest, 7.06 feet, February 24, 1994.

EXTREMES FOR PERIOD OF RECORD: Highest, 1.55 feet, June 9, 1995; lowest, 11.50 feet, April 1, 1991.
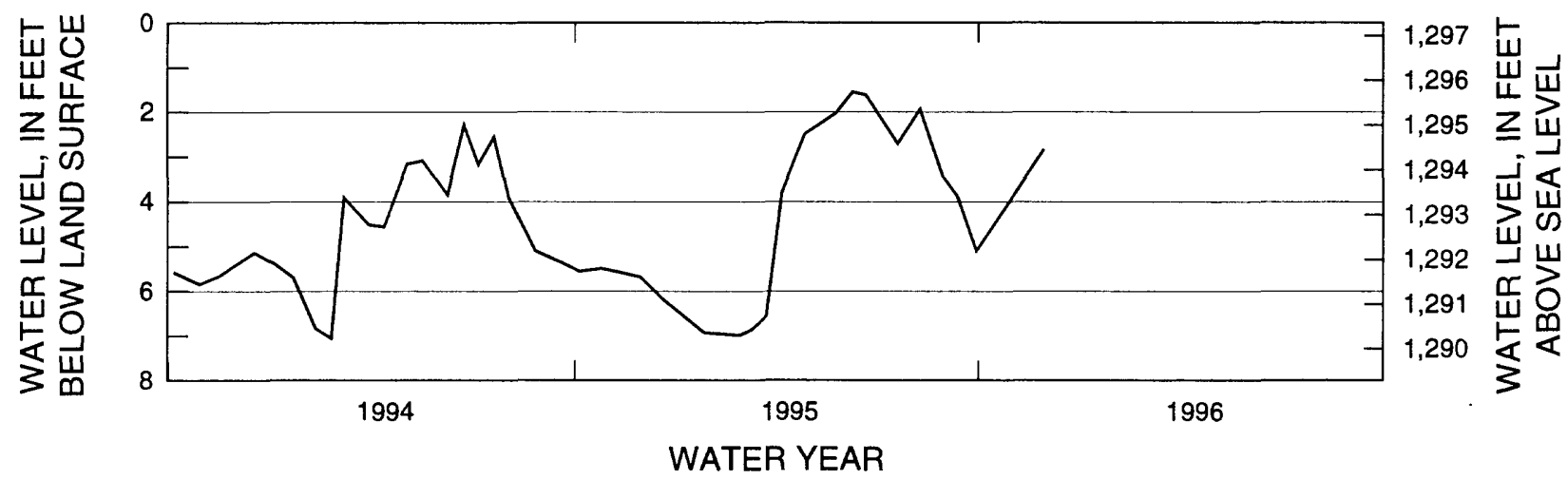

WATER YEAR

Figure 76. Hydrograph for observation well 110N62W9BBCC4, A-05-90, water years 1994-96.

LOCAL WELL NUMBER: 110N62W9BBCC5

SITE IDENTIFIER: 442113098174205

OTHER IDENTIFIER: A-06-90

ALTITUDE OF LAND SURFACE: $1,297.30$ feet

MEASURING POINT: 3.26 feet above land surface

AQUIFER: Till

PERIOD OF RECORD: November 5, 1990, to November 29, 1995

EXTREMES FOR PERIOD SHOWN: Highest, 0.13 feet, June 9, 1995; lowest, 5.88 feet, February 10, 1994.

EXTREMES FOR PERIOD OF RECORD: Highest, 0.12 feet, June 6, 1991; lowest, 6.98 feet, January $18,1991$.
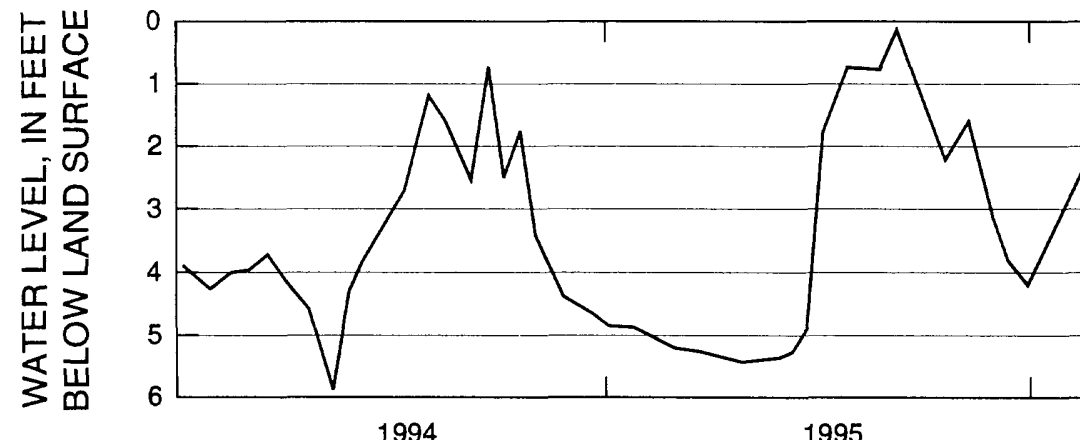
LOCAL WELL NUMBER: 110N62W9BBCC6

SITE IDENTIFIER: 442113098174206

OTHER IDENTIFIER: A-07-90

ALTITUDE OF LAND SURFACE: $1,297.30$ feet

MEASURING POINT: 2.28 feet above land surface

AQUIFER: Till

PERIOD OF RECORD: November 5, 1990, to November 29, 1995

EXTREMES FOR PERIOD SHOWN: Highest, 6.04 feet, September 12, 1995; lowest, 24.81 feet, March 7, 1994.

EXTREMES FOR PERIOD OF RECORD: Highest, 6.04 feet, September 12, 1995; lowest 34.57 feet,

December 7, 1990.

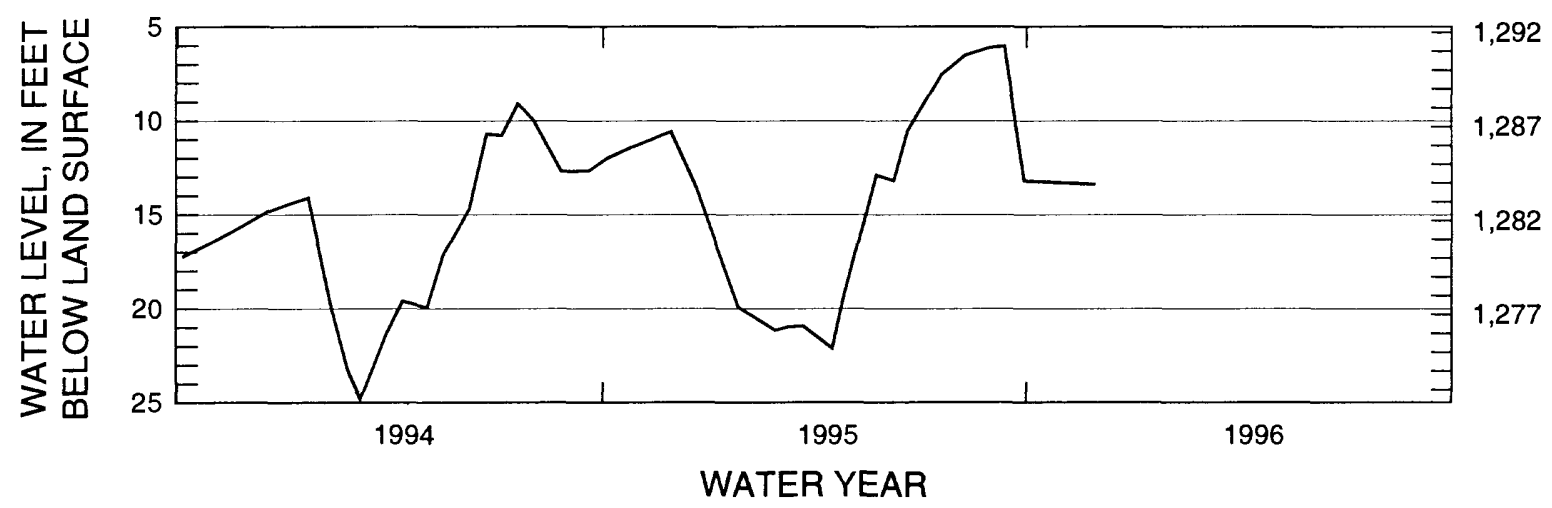

Figure 78. Hydrograph for observation well 110N62W9BBCC6, A-07-90, water years 1994-96.

LOCAL WELL NUMBER: 110N62W9BBCC7

SITE IDENTIFIER: 442113098174207

OTHER IDENTIFIER: A-08-90

ALTITUDE OF LAND SURFACE: $1,297.30$ feet

MEASURING POINT: 2.38 feet above land surface

AQUIFER: Till

PERIOD OF RECORD: November 5, 1990, to November 29, 1995

EXTREMES FOR PERIOD SHOWN: Highest, 2.73 feet, August 9, 1995; lowest, 9.64 feet, March 7, 1994. EXTREMES FOR PERIOD OF RECORD: Highest, 2.73 feet, August 9, 1995; lowest, 14.48 feet, April 1, 1991, April 19, 1991.
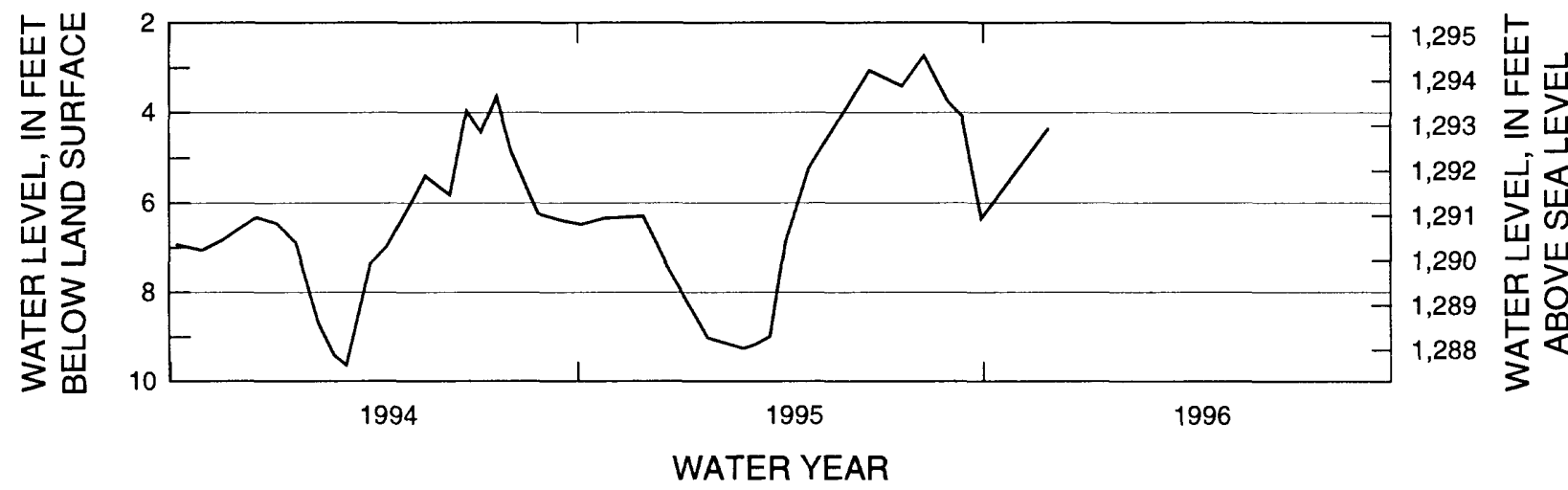

Figure 79. Hydrograph for observation well 110N62W9BBCC7, A-08-90, water years 1994-96. 
LOCAL WELL NUMBER: 110N62W9BBCC8

SITE IDENTIFIER: 442110098174201

OTHER IDENTIFIER: CO-09-90

ALTITUDE OF LAND SURFACE: $1,297.30$ feet

MEASURING POINT: 2.47 feet above land surface

AQUIFER: Warren

PERIOD OF RECORD: August 6, 1990, to November 29, 1995

EXTREMES FOR PERIOD SHOWN: Highest, 6.81 feet, September 11, 1995; lowest, 29.30 feet, February 24, 1994.

EXTREMES FOR PERIOD OF RECORD: Highest, 6.81 feet, September 11, 1995; lowest, 38.59 feet, November 5, 1990.

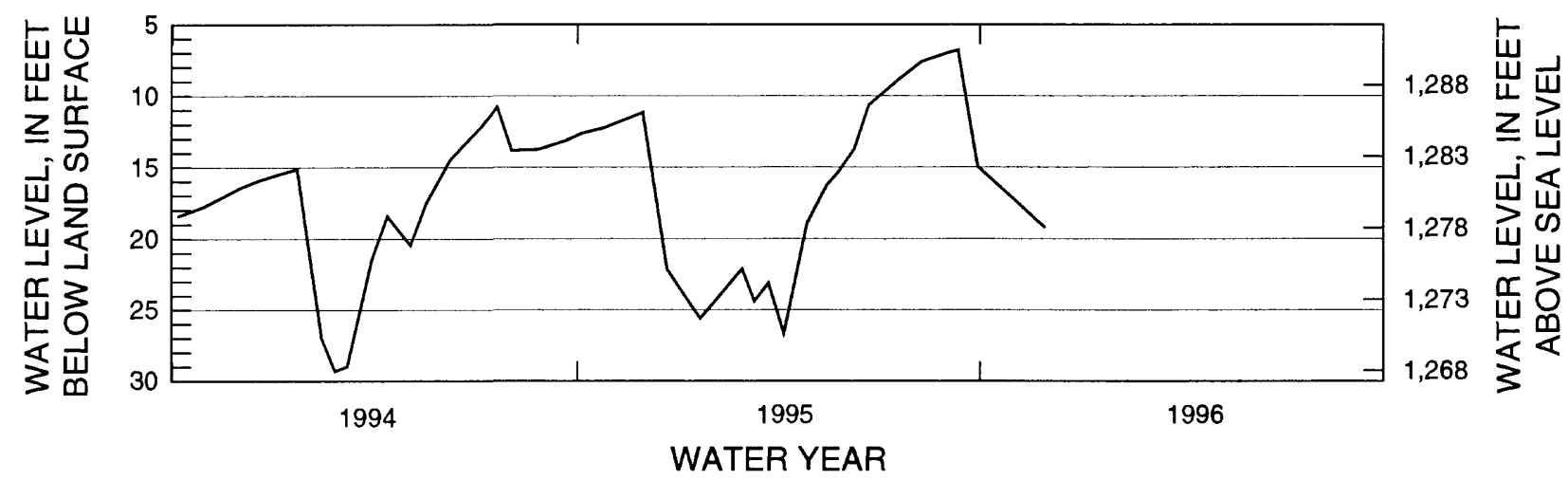

Figure 80. Hydrograph for observation well 110N62W9BBCC8, CO-09-90, water years 1994-96.

LOCAL WELL NUMBER: 110N62W9BBDD

SITE IDENTIFIER: 442110098172501

OTHER IDENTIFIER: CO-19-90

ALTITUDE OF LAND SURFACE: $1,296.52$ feet

MEASURING POINT: 2.57 feet above land surface

AQUIFER: Warren

PERIOD OF RECORD: November 6, 1990, to November 29, 1995

EXTREMES FOR PERIOD SHOWN: Highest, 6.16 feet, September 11, 1995; lowest, 26.15 feet, March 7, 1994. EXTREMES FOR PERIOD OF RECORD: Highest, 6.16 feet, September 11, 1995; lowest, 37.68 feet, November 21, 1990.
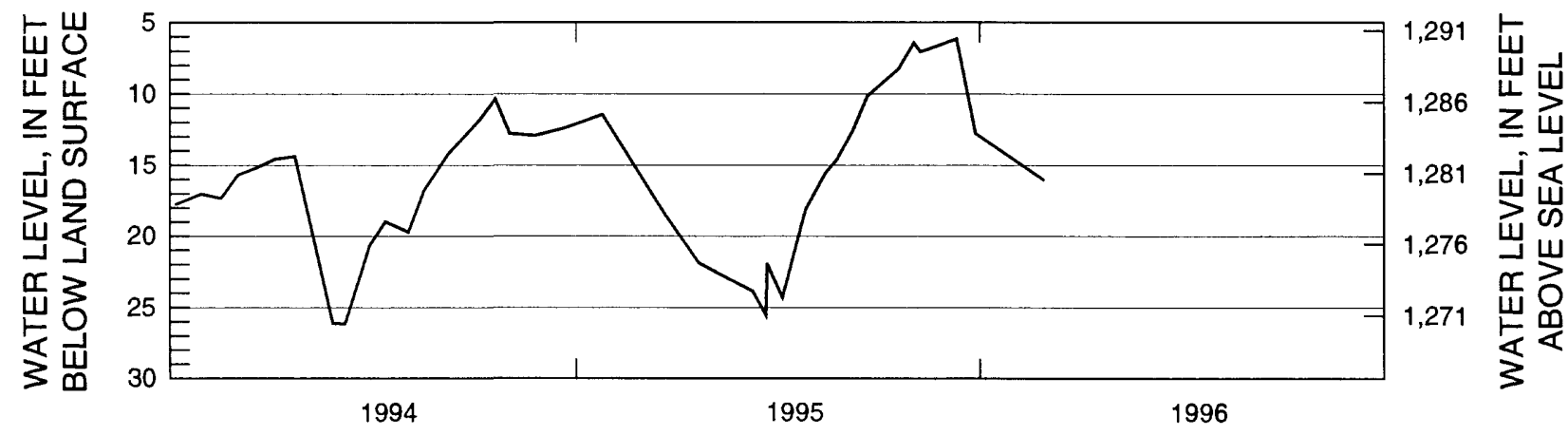

WATER YEAR

Figure 81. Hydrograph for observation well 110N62W9BBDD, CO-19-90, water years 1994-96. 
LOCAL WELL NUMBER: 110N62W9BCAB

SITE IDENTIFIER: 442108098173101

OTHER IDENTIFIER: CO-32-90

ALTITUDE OF LAND SURFACE: $1,305.75$ feet

MEASURING POINT: 2.80 feet above land surface

AQUIFER: Warren

PERIOD OF RECORD: November 5, 1990, to November 29, 1995

EXTREMES FOR PERIOD SHOWN: Highest, 15.48 feet, September 11, 1995; lowest, 38.44 feet, March 3, 1994.

EXTREMES FOR PERIOD OF RECORD: Highest, 15.48 feet, September 11, 1995; lowest, 51.07 feet, November 21, 1990.
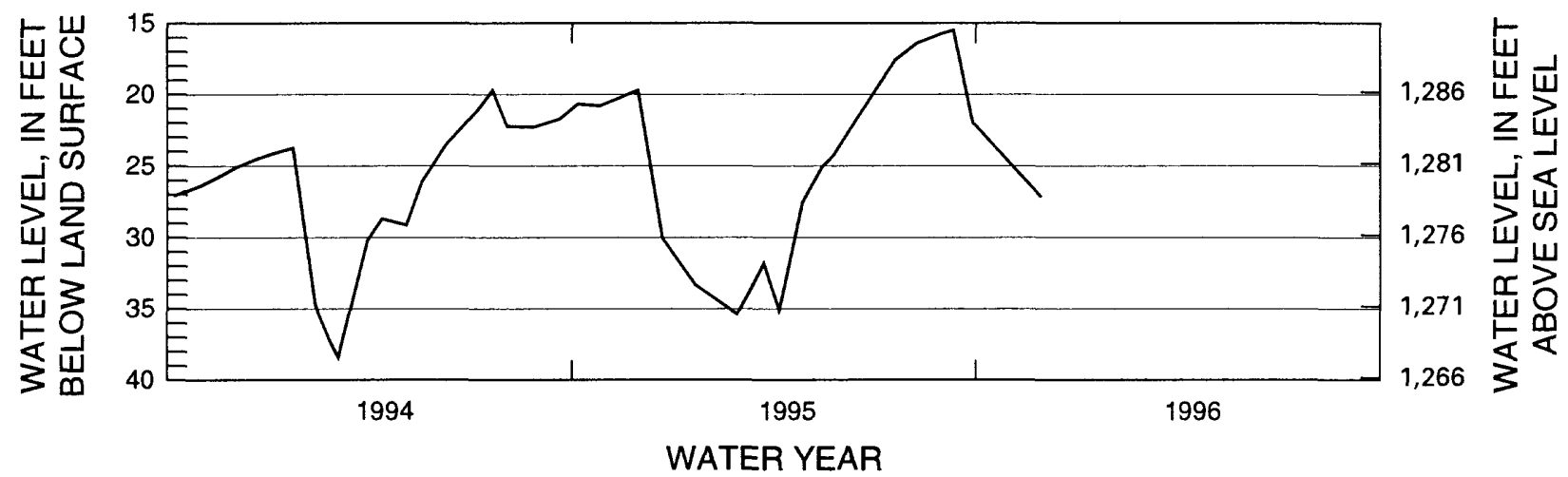

Figure 82. Hydrograph for observation well 110N62W9BCAB, CO-32-90, water years 1994-96.

LOCAL WELL NUMBER: 110N62W9BCBC

SITE IDENTIFIER: 442105098174001

OTHER IDENTIFIER: CO-68-90

ALTITUDE OF LAND SURFACE: $1,302.80$ feet

MEASURING POINT: 2.83 feet above land surface

AQUIFER: Warren

PERIOD OF RECORD: November 5, 1990, to November 29, 1995

EXTREMES FOR PERIOD SHOWN: Highest, 12.32 feet, August 30, 1995; lowest, 41.52 feet, March 11, 1994. EXTREMES FOR PERIOD OF RECORD: Highest, 12.32 feet, August 30, 1995; lowest, 48.95 feet, November 5, 1990.
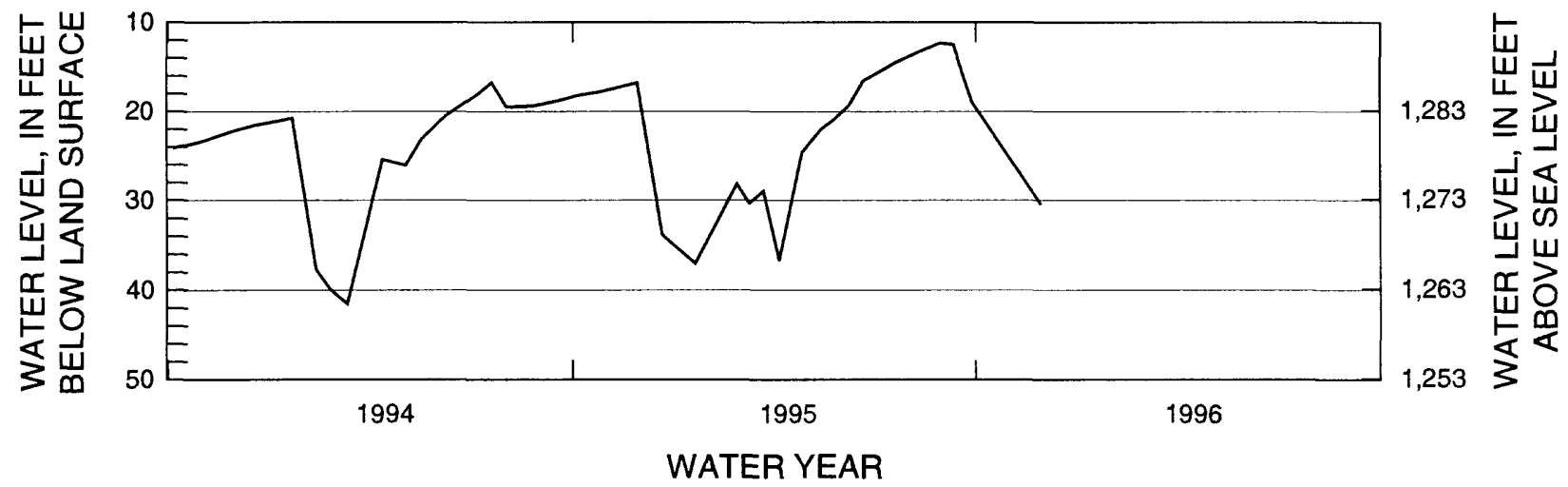

Figure 83. Hydrograph for observation well 110N62W9BCBC, CO-68-90, water years 1994-96. 
LOCAL WELL NUMBER: 110N62W9BCDD

SITE IDENTIFIER: 442057098172501

OTHER IDENTIFIER: CO-10-90

ALTITUDE OF LAND SURFACE: $1,301.09$ feet

MEASURING POINT: 2.70 feet above land surface

AQUIFER: Warren

PERIOD OF RECORD: August 6, 1990, to November 29, 1995

EXTREMES FOR PERIOD SHOWN: Highest, 11.34 feet, September 11, 1995; lowest, 33.39 feet, April 27, 1995.

EXTREMES FOR PERIOD OF RECORD: Highest, 11.34 feet, September 11, 1995; lowest, 42.26 feet, November 21, 1990.
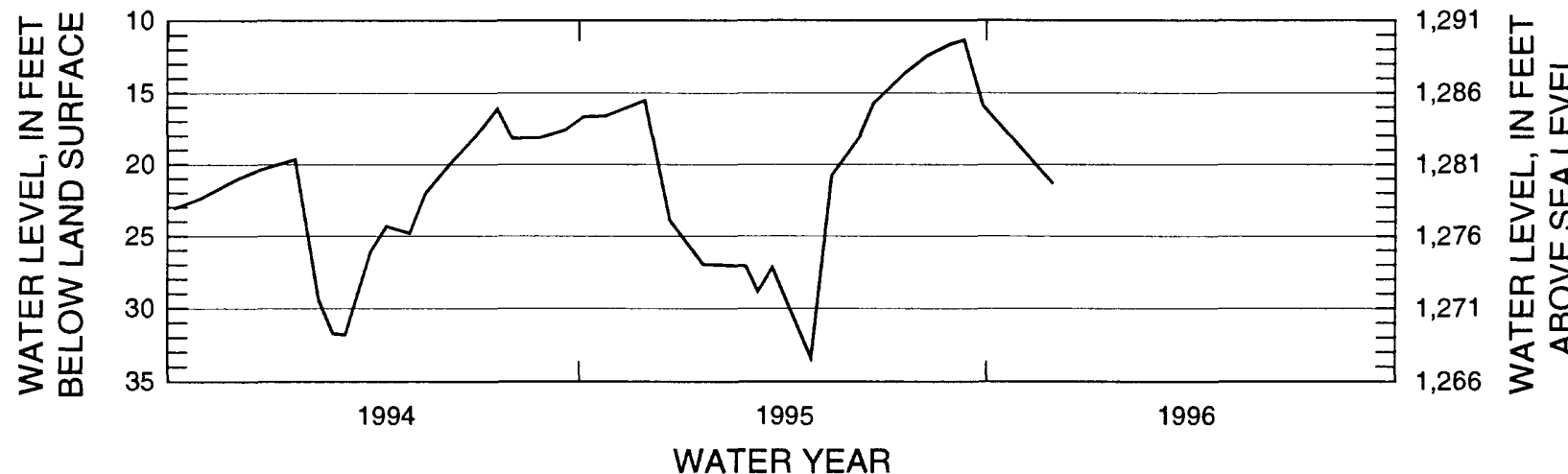

WATER YEAR

Figure 84. Hydrograph for observation well 110N62W9BCDD, CO-10-90, water years 1994-96.

LOCAL WELL NUMBER: 110N62W10CCCC

SITE IDENTIFIER: 442002098162801

OTHER IDENTIFIER: CO-11-90

ALTITUDE OF LAND SURFACE: $1,294.32$ feet

MEASURING POINT: 2.83 feet above land surface

AQUIFER: Warren

PERIOD OF RECORD: August 15, 1990, to September 29, 1995

EXTREMES FOR PERIOD SHOWN: Highest 6.31 feet, September 11, 1995; lowest, 19.63 feet, March 9, 1995.

EXTREMES FOR PERIOD OF RECORD: Highest, 6.31 feet, September 11, 1995, lowest, 33.25 feet,

December 26, 1990.
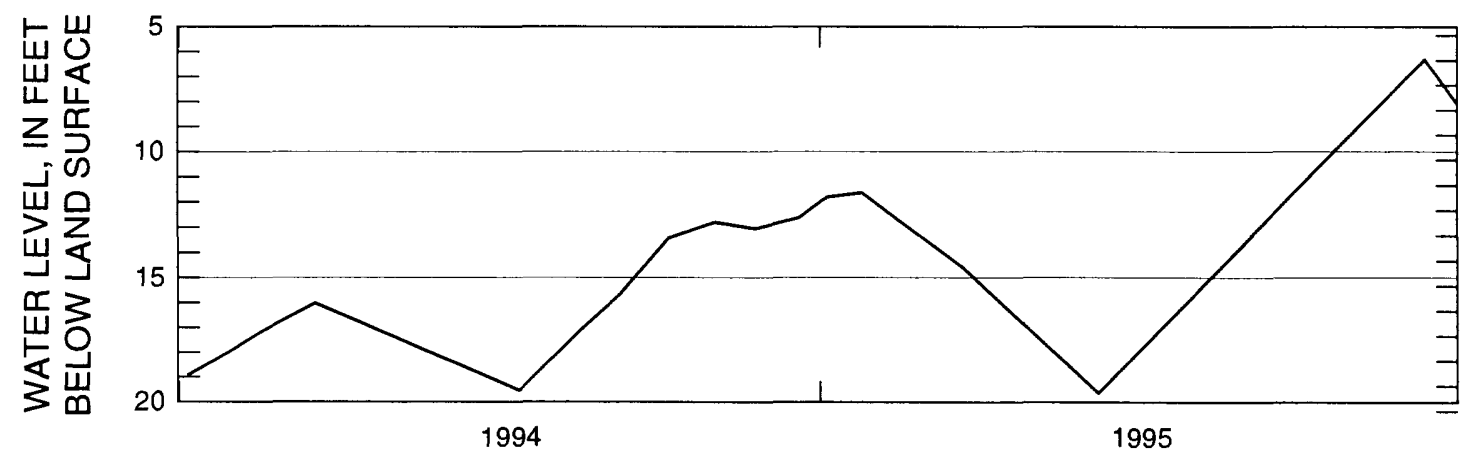

1,289

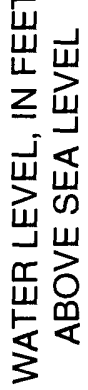

WATER YEAR

Figure 85. Hydrograph for observation well 110N62W10CCCC, CO-11-90, water years 1994-95. 
LOCAL WELL NUMBER: 110N62W10DDDD

SITE IDENTIFIER: 442031098151801

OTHER IDENTIFIER: CO-12-90

ALTITUDE OF LAND SURFACE: $1,288.17$ feet

MEASURING POINT: 2.68 feet above land surface

AQUIFER: Warren

PERIOD OF RECORD: August 15, 1990, to November 29, 1995

EXTREMES FOR PERIOD SHOWN: Highest, 4.93 feet, November 29, 1995; lowest, 7.05 feet, February 24, 1995.

EXTREMES FOR PERIOD OF RECORD: Highest, 4.93 feet, November 29, 1995; lowest, 13.86 feet, July 9, 1991.

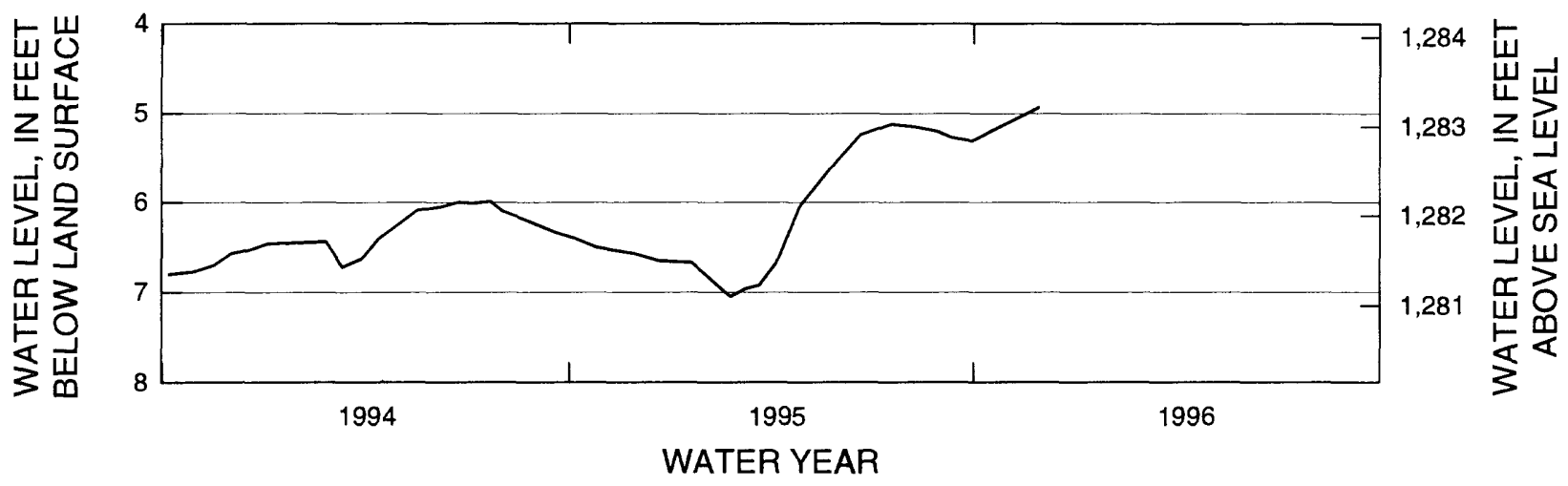

Figure 86. Hydrograph for observation well 110N62W10DDDD, CO-12-90, water years 1994-96.

LOCAL WELL NUMBER: 110N62W16BBAA

SITE IDENTIFIER: 442032098172501

OTHER IDENTIFIER: CO-13-90

ALTITUDE OF LAND SURFACE: $1,303.73$ feet

MEASURING POINT: 2.96 feet above land surface

AQUIFER: Warren

PERIOD OF RECORD: August 15, 1990, to November 29, 1995

EXTREMES FOR PERIOD SHOWN: Highest, 14.11 feet, September 11, 1995; lowest, 36.52 feet, March 11, 1994.

EXTREMES FOR PERIOD OF RECORD: Highest, 14.11 feet, September 11, 1995; lowest, 47.35 feet, February 20, 1991.

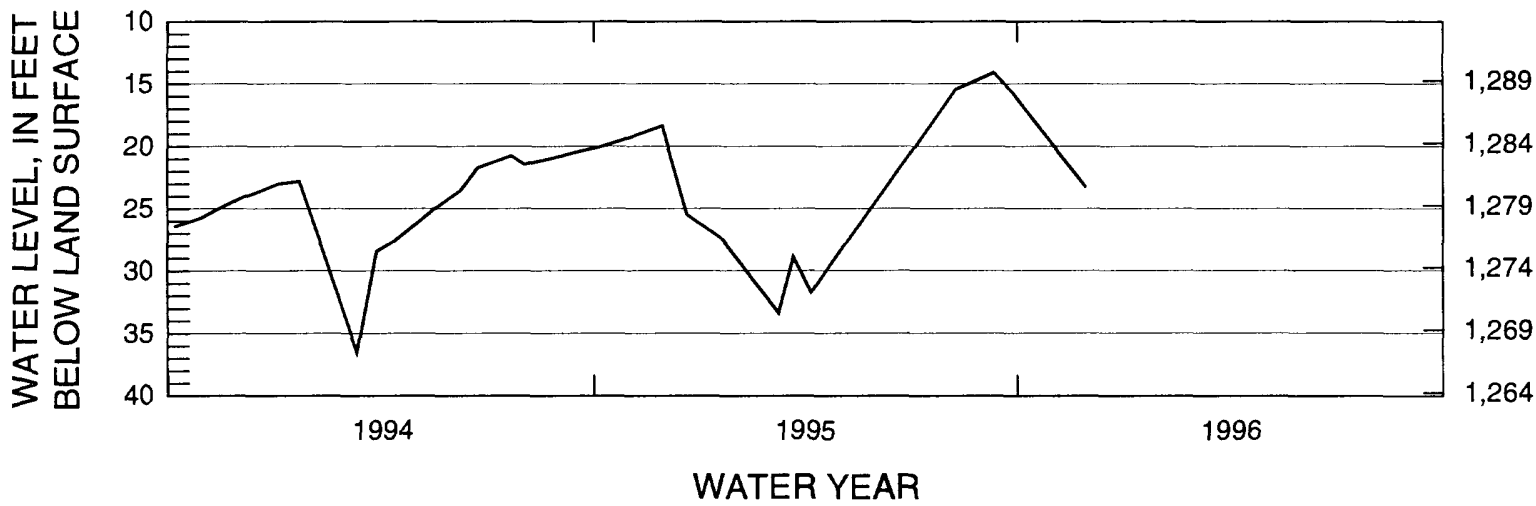

Figure 87. Hydrograph for observation well 110N62W16BBAA, CO-13-90, water years 1994-96. 
LOCAL WELL NUMBER: 110N62W21AAAA

SITE IDENTIFIER: 441937098163001

OTHER IDENTIFIER: CO-21-90

ALTITUDE OF LAND SURFACE: $1,311.93$ feet

MEASURING POINT: 2.43 feet above land surface

AQUIFER: Warren

PERIOD OF RECORD: November 5, 1990, to November 29, 1995

EXTREMES FOR PERIOD SHOWN: Highest, 26.33 feet, September 27, 1995; lowest, 41.15 feet, October 6, 1993.

EXTREMES FOR PERIOD OF RECORD: Highest, 26.33 feet, September 27, 1995; lowest, 49.40 feet, May 1, 1991.
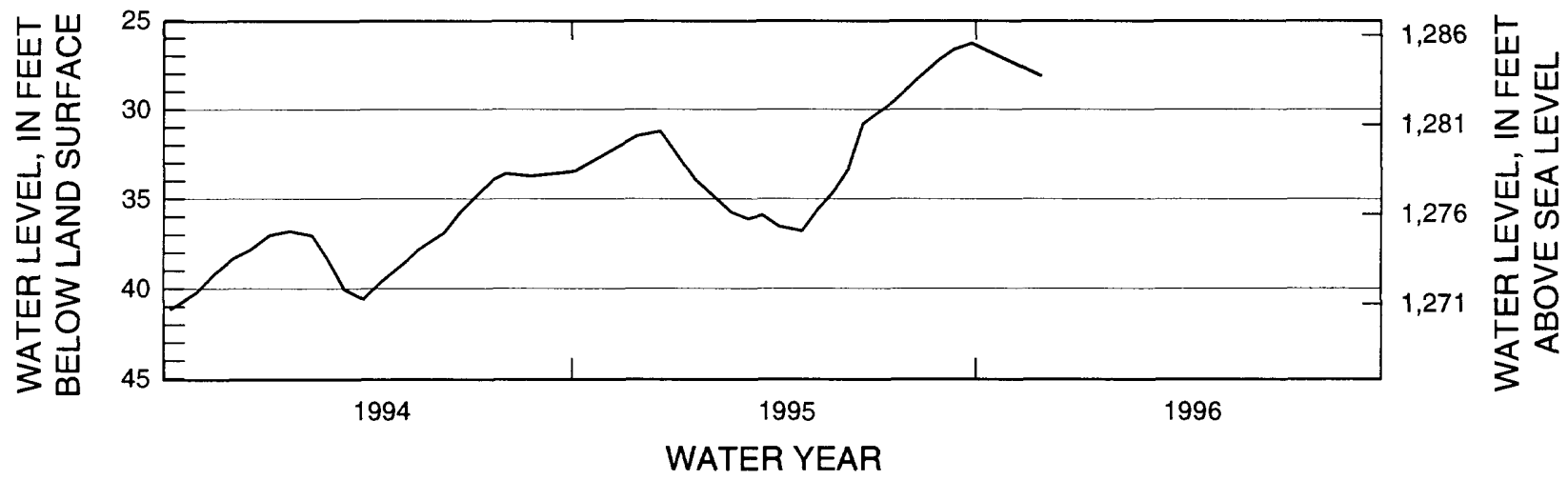

Figure 88. Hydrograph for observation well 110N62W21AAAA, CO-21-90, water years 1994-96.

LOCAL WELL NUMBER: 110N62W21BBBB

SITE IDENTIFIER: 441937098174001

OTHER IDENTIFIER: CO-20-90

ALTITUDE OF LAND SURFACE: $1,307.19$ feet

MEASURING POINT: 2.54 feet above land surface

AQUIFER: Warren

PERIOD OF RECORD: November 5, 1990, to November 29, 1995

EXTREMES FOR PERIOD SHOWN: Highest, 19.48 feet, September 29, 1995; lowest, 32.52 feet, March 11, 1994.

EXTREMES FOR PERIOD OF RECORD: Highest, 19.48 feet, September 29, 1995; lowest, 52.69 feet, July 9, 1991.
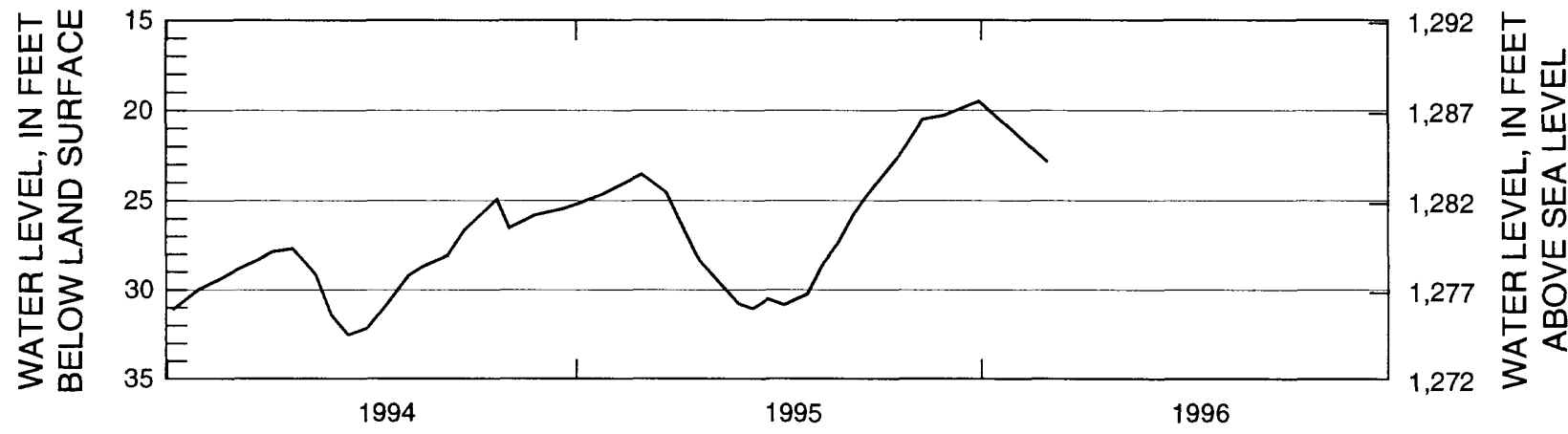

WATER YEAR

Figure 89. Hydrograph for observation well 110N62W21BBBB, CO-20-90, water years 1994-96. 
LOCAL WELL NUMBER: 110N62W22AAAA

SITE IDENTIFIER: 441937098151701

OTHER IDENTIFIER: CO-22-90

ALTITUDE OF LAND SURFACE: $1,304.85$ feet

MEASURING POINT: 3.06 feet above land surface

AQUIFER: Warren

PERIOD OF RECORD: November 5, 1990, to November 29, 1995

EXTREMES FOR PERIOD SHOWN: Highest, 20.32 feet, November 29, 1995; lowest, 27.22 feet, October 6, 1993.

EXTREMES FOR PERIOD OF RECORD: Highest, 20.32 feet, November 29, 1995; lowest, 28.59 feet, June 12, 1992.

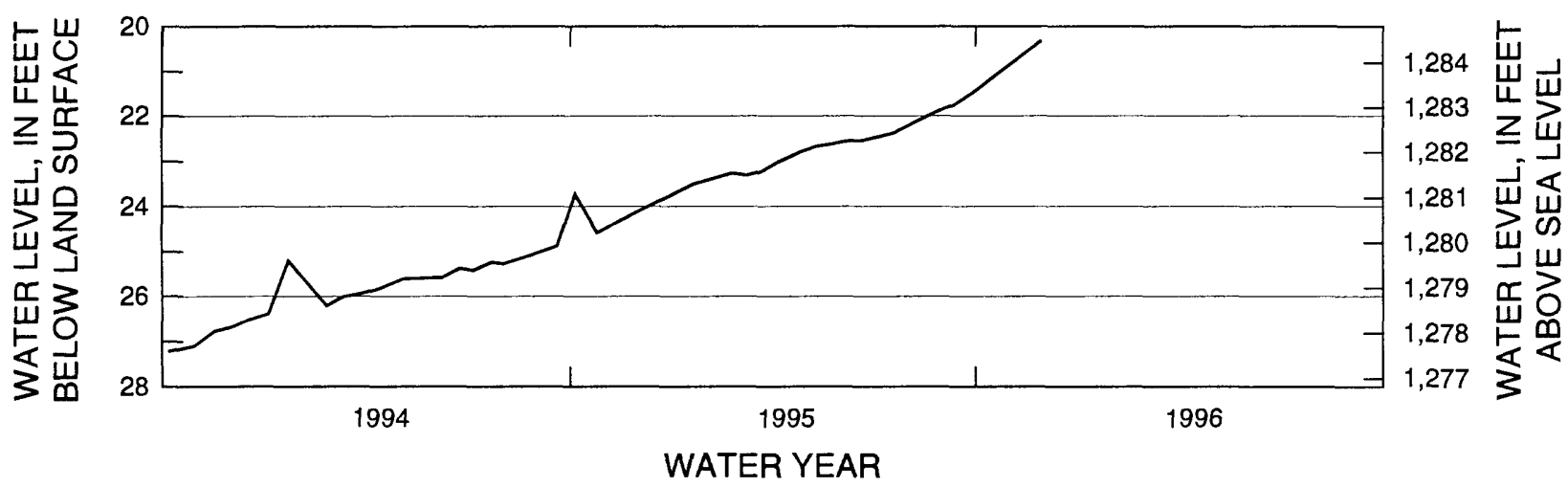

Figure 90. Hydrograph for observation well 110N62W22AAAA, CO-22-90, water years 1994-96. 


\section{INJECTION DATA}

Recharge water was injected into the Warren aquifer from June 2, 1994, through July 29, 1994, and from June 14, 1995, through September 13, 1995. The injection rates and the cumulative volume of injected water into the aquifer were frequently monitored during the recharge phase. Plots of the injection rates and the cumulative volume of water are shown in figure 91 for the 1994 recharge period and in figure 92 for the 1995 recharge period. During the 1994 recharge period, the total volume of injected water was $9,223,800$ gallons, at an average flow rate of 137 gallons per minute. During the 1995 recharge period, the total volume of injected water was $9,184,000$ gallons, at an average flow rate of 77 gallons per minute.

The injection of water was halted on several occasions during both the 1994 and 1995 recharge periods. Recharge ceased from June 3-7, 1994, in order to repair a break in the pipeline between Huron's water treatment plant and the recharge well. Recharge also was halted in 1994 from June 30 to July 5 due to repairs at the water treatment plant. During the 1995 recharge period, injection was ceased from July 26-28 in order to regenerate the recharge well.

\section{WATER-QUALITY DATA}

Samples were collected and analyzed to provide information on the water quality of the Warren aquifer before, during, and after the injection of the treated James River water. Water-quality data from the James River and treated water from the Huron Water Treatment plant also were collected. This section presents data collected from the quality-assurance, screening, detailed, and plume-monitoring water-quality sampling programs.

Quality-assurance samples were collected to evaluate the collection and field processing methods of water-quality samples and to evaluate the precision and accuracy of the reported analytical results for inorganic contituents in samples that were submitted to laboratories. Quality-control data were provided by the USGS National Water Quality Laboratory (NWQL) for organic compounds; however, these data are not presented in this report.

The screening sampling program was designed to establish baseline water-quality data for a relatively large area using a limited parameter list. These data will be useful for assessing general water-quality changes that may have occurred in the aquifer due to artificial recharge. The detailed sampling program was designed to provide more detailed water-quality data and thus, includes a more extensive parameter list. The plume-monitoring sampling program was designed to monitor the progression of the recharge plume as it moved from the recharge well to nearby observation wells by using water-quality parameters. The concentrations of several parameters varied greatly between the recharge water and aquifer water and were used as tracers of the recharge plume. For example, iron concentrations generally were 300 times greater in the aquifer water than in the recharge water. Therefore, the advancement of the recharge plume to an observation well could be identified when the iron concentration of the observation well decreased due to the mixing of aquifer and recharge waters.

Three agencies assisted in the collection and analyses of the water-quality samples for both the screening and the detailed sampling programs. Samples and field parameters were collected by either USGS or SDSU field personnel. Laboratory analyses were performed by the USGS NWQL, South Dakota Department of Health Laboratory, or SDSU Northern Great Plains Water Resources Research Center (NGPWRRC) Laboratory. All data for the plumemonitoring sampling program were collected by SDSU field personnel and analyzed by the NGPWRRC Laboratory.

All ground-water samples were collected by using a submersible pump after a minimum of three well volumes had been purged from the well and specific-conductance values had stabilized. Samples from the James River also were collected by using a submersible pump after specific-conductance values had stabilized. The treatment plant effluent was collected from a faucet at the plant after specific-conductance values had stabilized.

Measurements of specific conductance, $\mathrm{pH}$, temperature, dissolved oxygen, and oxidation-reduction potential were made onsite. Sample processing, including filtration and acidification, was performed onsite.

\section{Quality-Assurance Data}

Quality-assurance samples were collected to evaluate the collection and field-processing methods of water-quality samples and to evaluate the precision and accuracy of the reported analytical results. These quality-assurance samples included blanks, duplicates, and blind duplicates. 

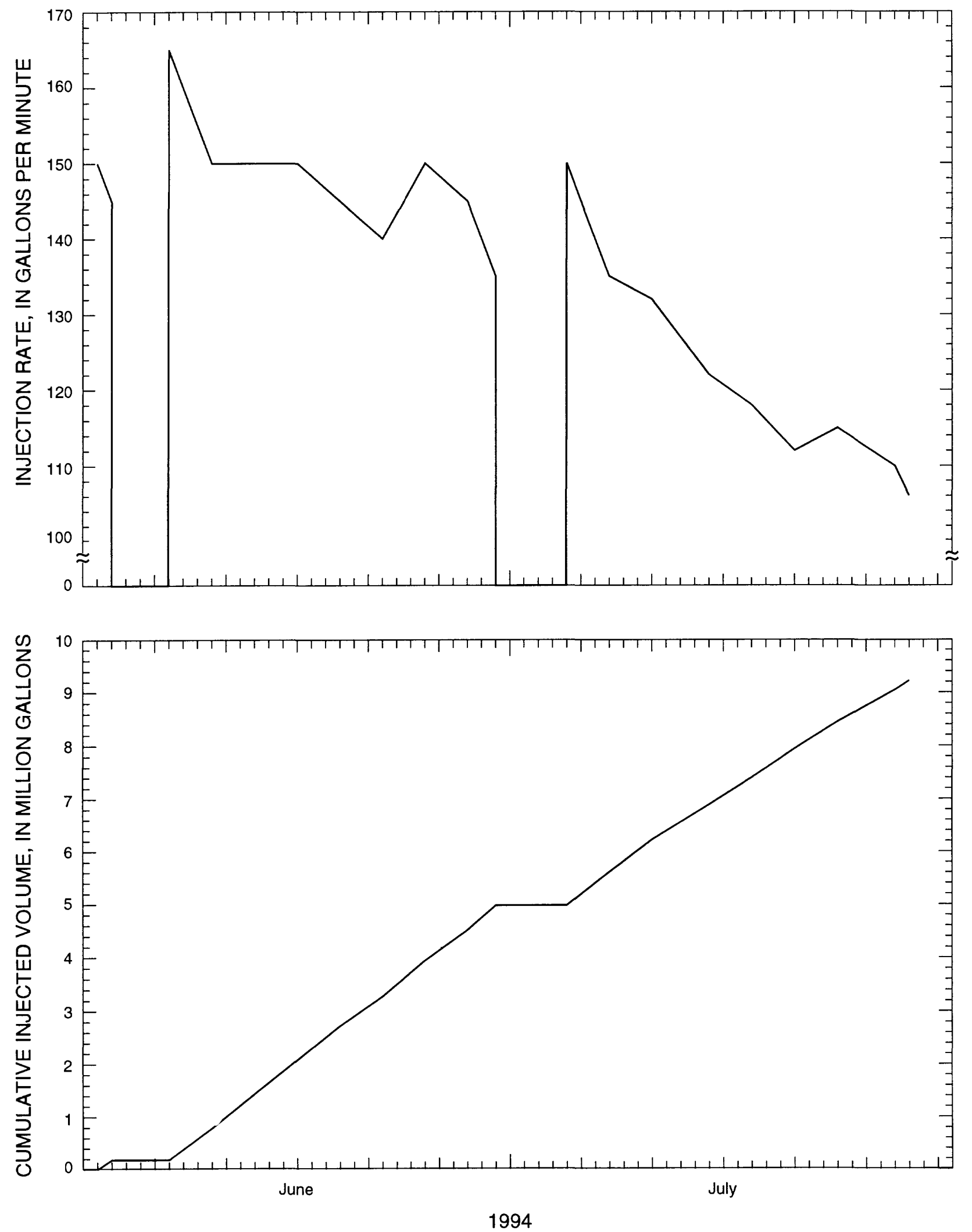

Figure 91. Injection rate and cumulative volume of injected recharge water for 1994 recharge period. 

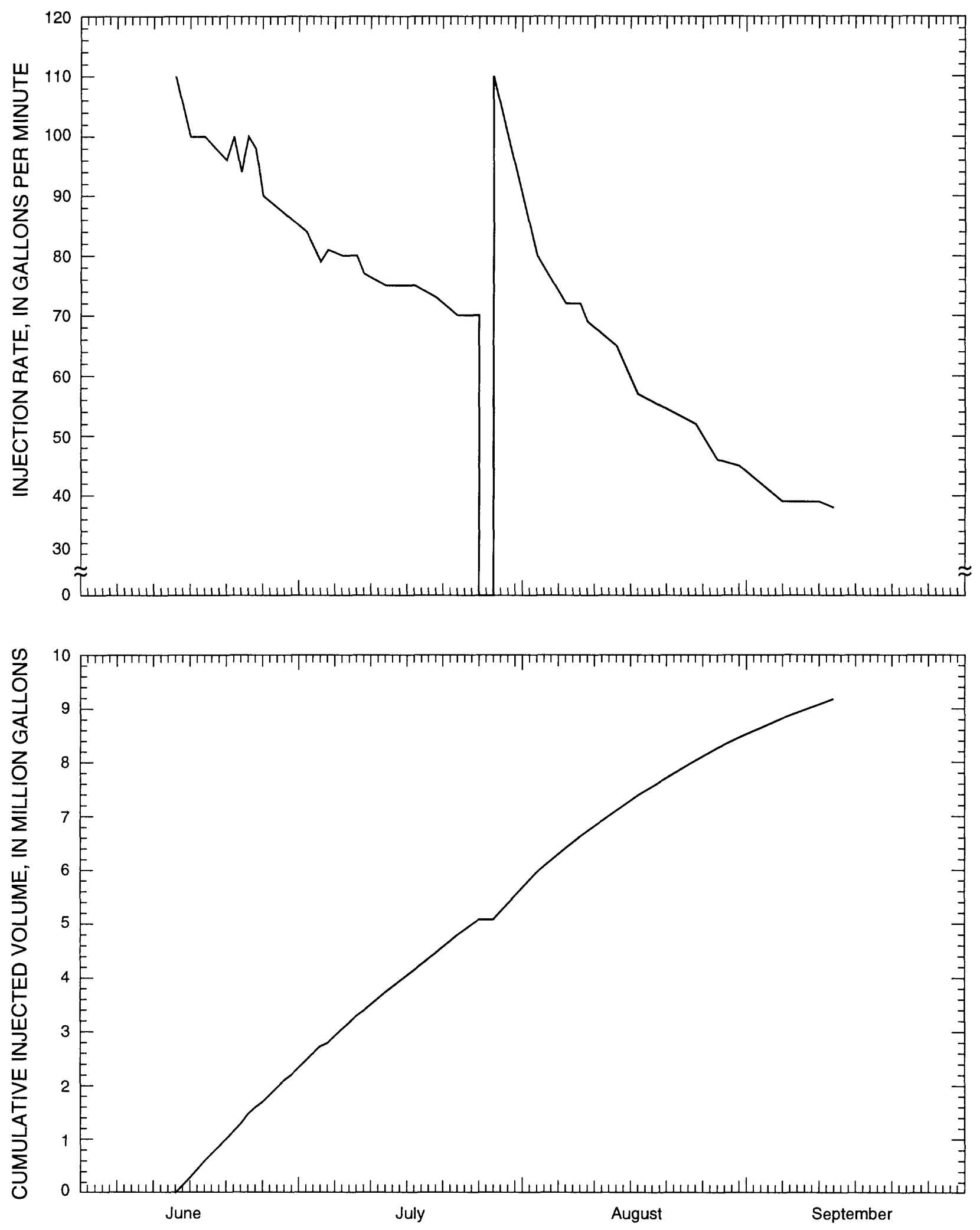

1995

Figure 92. Injection rate and cumulative volume of injected recharge water for 1995 recharge period. 
Blank samples, including laboratory equipment blanks and field equipment blanks were collected and analyzed to identify the presence and magnitude of contamination that potentially could bias analytical results. Laboratory equipment blanks are samples of ultra-pure deionized water that are processed in a laboratory or other controlled environment through the sampling equipment used in this study; laboratory blanks are used to identify sample contamination introduced from the sampling equipment. Field equipment blanks are samples of ultra-pure deionized water that are processed through the sampling equipment at the field collection site; field blanks are used to identify sample contamination introduced from the sampling equipment and contamination introduced during collection and processing of samples in the field. Three laboratory blanks and one field blank were collected during the period presented in this report. The analytical results of the blank samples are presented in table 4 . Generally, the laboratory and field equipment blanks indicated that external contamination did not substantially contribute to concentrations of constituents presented in this report.

Table 4. Concentrations of inorganic constituents obtained from quality-assurance sample blanks

[All analyses on unfiltered samples unless otherwise specified. All sanples collected by U.S. Geological Survey and analyzed by National Water Quality Laboratory. mg/L, milligrams per liter; $\mathrm{mL}$, milliliter; $\mu \mathrm{g} / \mathrm{L}$, micrograms per liter; deg, degrees; <, less than; --, no data]

\begin{tabular}{|c|c|c|c|c|c|c|c|c|c|}
\hline Station name & Date & $\begin{array}{c}\text { Calcium, } \\
\text { filtered } \\
\text { (mg/L } \\
\text { as Ca) } \\
\text { (00915) }\end{array}$ & $\begin{array}{l}\text { Magne- } \\
\text { sium, } \\
\text { filtered } \\
\text { (mgll } \\
\text { as Mg) } \\
(00925)\end{array}$ & $\begin{array}{c}\text { Sodium } \\
\text { (mg/L } \\
\text { as } \mathrm{Na}) \\
(00930)\end{array}$ & $\begin{array}{l}\text { Potas- } \\
\text { sium, } \\
\text { filtered } \\
\text { (mg/L } \\
\text { as K) } \\
(00935)\end{array}$ & $\begin{array}{c}\text { Sulfate, } \\
\text { filtered } \\
\text { (mg/L } \\
\left.\text { as } \mathrm{SO}_{4}\right) \\
(00945)\end{array}$ & $\begin{array}{c}\text { Chloride, } \\
\text { filtered } \\
\text { (mg/L } \\
\text { as Cl) } \\
(00940)\end{array}$ & $\begin{array}{c}\text { Fluoride, } \\
\text { filtered } \\
\text { (mg/L } \\
\text { as F) } \\
(00950)\end{array}$ & $\begin{array}{c}\text { Silica, } \\
\text { filtered } \\
\left(\mathrm{mgll}^{2} \text { as }\right. \\
\left.\mathrm{SiO}_{2}\right) \\
(00955)\end{array}$ \\
\hline Laboratory blank & $02-10-94$ & 0.03 & 0.00 & 0.03 & -- & -- & -- & -- & $<0.02$ \\
\hline Laboratory blank & $12-05-94$ & 0.01 & 0.00 & $<0.03$ & -- & -- & -- & -- & 0.03 \\
\hline Laboratory blank & $09-15-95$ & 0.06 & 0.03 & 0.09 & -- & - & -- & -- & 0.02 \\
\hline Field blank & $04-24-95$ & 0.45 & 0.08 & $<0.20$ & $<0.10$ & 0.20 & $<0.10$ & $<0.10$ & 0.16 \\
\hline
\end{tabular}

\begin{tabular}{|c|c|c|c|c|c|c|c|c|}
\hline Station name & Date & $\begin{array}{l}\text { Solids, } \\
\text { residue } \\
\text { at } 180 \\
\text { deg C, } \\
\text { filtered } \\
(\mathrm{mg} / \mathrm{L}) \\
(70300)\end{array}$ & $\begin{array}{l}\text { Residue } \\
\text { at } 105 \\
\text { deg C, } \\
\text { filtered } \\
\text { (mg/L) } \\
(00515)\end{array}$ & $\begin{array}{c}\text { Nitrogen, } \\
\text { ammonia, } \\
\text { filtered } \\
\text { (mg/l } \\
\text { as } N) \\
(00608)\end{array}$ & $\begin{array}{c}\text { Nitrogen, } \\
\text { nitrite, } \\
\text { filtered } \\
\text { (mg/L } \\
\text { as N) } \\
(00613)\end{array}$ & $\begin{array}{c}\text { Nitrogen, } \\
\mathrm{NO}_{2}+\mathrm{NO}_{3} \text {, } \\
\text { filtered } \\
(\mathrm{mg} / \mathrm{L} \\
\text { as } \mathrm{N}) \\
(00631)\end{array}$ & $\begin{array}{c}\text { Phos- } \\
\text { phorus } \\
\text { ortho, } \\
\text { filtered } \\
\text { (mg/L } \\
\text { as P) } \\
(00671)\end{array}$ & $\begin{array}{c}\text { Aluminum, } \\
\text { filtered } \\
(\mu g / L \\
\text { as Al) } \\
(01106)\end{array}$ \\
\hline Laboratory blank & $02-10-94$ & -- & -- & $<0.002$ & 0.001 & $<0.005$ & $<0.001$ & 3 \\
\hline Laboratory blank & $09-15-95$ & -- & -- & $<0.002$ & 0.001 & $<0.005$ & $<0.001$ & 2 \\
\hline Field blank & $04-24-95$ & 3 & 3 & -- & -- & -- & -- & -- \\
\hline
\end{tabular}

\begin{tabular}{|c|c|c|c|c|c|c|c|c|c|}
\hline Station name & Date & $\begin{array}{l}\text { Antimony, } \\
\text { filtered } \\
(\mu g / L \\
\text { as Sb) } \\
(01095)\end{array}$ & $\begin{array}{c}\text { Arsenic, } \\
\text { filtered } \\
(\mu \mathrm{g} / \mathrm{L} \\
\text { as As) } \\
(01000)\end{array}$ & $\begin{array}{c}\text { Barium, } \\
\text { filtered } \\
(\mu \mathrm{g} / \mathrm{L} \\
\text { as Ba) } \\
(01005)\end{array}$ & $\begin{array}{c}\text { Beryllium, } \\
\text { filtered } \\
(\mu \mathrm{g} / \mathrm{L} \\
\text { as Be) } \\
(01010)\end{array}$ & $\begin{array}{c}\text { Boron, } \\
\text { filtered } \\
(\mu \mathrm{g} / \mathrm{L} \\
\text { as B) } \\
(01020)\end{array}$ & $\begin{array}{l}\text { Cadmium, } \\
\text { filtered } \\
\text { ( } \mu \text { g/L } \\
\text { as Cd) } \\
(01025)\end{array}$ & $\begin{array}{c}\text { Chromium, } \\
\text { filtered } \\
(\mu \mathrm{g} / \mathrm{L} \\
\text { as Cr) } \\
(01030)\end{array}$ & $\begin{array}{c}\text { Cobalt, } \\
\text { filtered } \\
(\mu g / L \\
\text { as Co) } \\
(01035)\end{array}$ \\
\hline Laboratory blank & $02-10-94$ & $<0.2$ & -- & 0.3 & $<0.2$ & $<20$ & $<0.3$ & 0 & $<0.2$ \\
\hline Laboratory blank & $12-05-94$ & $<0.2$ & -- & $<0.2$ & $<0.2$ & $<2$ & $<0.2$ & $<0$ & $<0.2$ \\
\hline Field blank & $04-24-95$ & -- & $<1$ & $<2$ & $<0.5$ & $<10$ & $<1.0$ & $<5$ & $<3$ \\
\hline
\end{tabular}


Table 4. Concentrations of inorganic constituents obtained from quality-assurance sample blanks-Continued

\begin{tabular}{|c|c|c|c|c|c|c|c|c|}
\hline Station name & Date & $\begin{array}{c}\text { Copper, } \\
\text { filtered } \\
(\mu g / L \\
\text { as Cu) } \\
(01040)\end{array}$ & $\begin{array}{c}\text { Iron, } \\
\text { filtered } \\
(\mu g / L \\
\text { as Fe) } \\
(01046)\end{array}$ & $\begin{array}{c}\text { Lead, } \\
\text { filtered } \\
(\mu \mathrm{g} / \mathrm{L} \\
\text { as Pb) } \\
(01049)\end{array}$ & $\begin{array}{c}\text { Lithium, } \\
\text { filtered } \\
(\mu \mathrm{g} / \mathrm{L} \\
\text { as Li) } \\
(01130)\end{array}$ & $\begin{array}{l}\text { Manga- } \\
\text { nese, } \\
\text { filtered } \\
(\mu g / L \\
\text { as Mn) } \\
(01056)\end{array}$ & $\begin{array}{c}\text { Mercury, } \\
\text { filtered } \\
(\mu g / L \\
\text { as Hg) } \\
(71890)\end{array}$ & $\begin{array}{c}\text { Molyb- } \\
\text { denum, } \\
\text { filtered } \\
(\mu \mathrm{g} / \mathrm{L} \\
\text { as Mo) } \\
(01060)\end{array}$ \\
\hline Laboratory blank & $02-10-94$ & 0.4 & 5 & $<0.3$ & -- & $<0.1$ & -- & $<0.2$ \\
\hline Laboratory blank & $12-05-94$ & $<0.2$ & $<3$ & $<0.3$ & -- & $<0.1$ & -- & $<0.2$ \\
\hline Laboratory blank & $09-15-95$ & $<0.2$ & $<3$ & $<0.3$ & -- & 0.1 & -- & $<0.2$ \\
\hline Field blank & $04-24-95$ & $<10$ & 12 & $<10$ & $<4$ & $<1$ & $<0.1$ & $<10$ \\
\hline
\end{tabular}

\begin{tabular}{|c|c|c|c|c|c|c|c|c|}
\hline Station name & Date & $\begin{array}{c}\text { Nickel, } \\
\text { filtered } \\
(\mu \mathrm{g} / \mathrm{L} \\
\text { as Ni) } \\
(01065)\end{array}$ & $\begin{array}{c}\text { Silver, } \\
\text { filtered } \\
(\mu \mathrm{g} / \mathrm{L} \\
\text { as Ag) } \\
(01075)\end{array}$ & $\begin{array}{c}\text { Strontium, } \\
\text { filtered } \\
(\mu \mathrm{g} / \mathrm{L} \\
\text { as } \mathrm{Sr}) \\
(01080)\end{array}$ & $\begin{array}{c}\text { Thallium, } \\
\text { filtered } \\
(\mu \mathrm{g} / \mathrm{L} \\
\text { as TI) } \\
(01057)\end{array}$ & $\begin{array}{l}\text { Uranium, } \\
\text { natural, } \\
\text { filtered } \\
(\mu \mathrm{g} / \mathrm{L} \\
\text { as U) } \\
(22703)\end{array}$ & $\begin{array}{c}\text { Vanadium, } \\
\text { filtered } \\
(\mu \mathrm{g} / \mathrm{L} \\
\text { as V) } \\
(01085)\end{array}$ & $\begin{array}{c}\text { Zinc, } \\
\text { filtered } \\
(\mu \mathrm{g} / \mathrm{L} \\
\text { as Zn) } \\
(01090)\end{array}$ \\
\hline Laboratory blank & $02-10-94$ & $<1$ & $<0.2$ & $<0.1$ & $<0.1$ & $<0.20$ & - & 1 \\
\hline Laboratory blank & $12-05-94$ & $<1$ & $<0.2$ & $<0.1$ & $<0.1$ & $<0.20$ & -- & $<1$ \\
\hline Laboratory blank & $09-15-95$ & $<1$ & $<0.2$ & 0.2 & $<0.1$ & $<0.20$ & -- & 1 \\
\hline Field blank & $04-24-95$ & $<10$ & 2.0 & 4 & -- & -- & $<6$ & 3 \\
\hline
\end{tabular}

Duplicate samples are two samples collected as close in time as possible and are considered to be essentially identical in composition. A total of 26 sets of duplicate samples were collected to assess the precision of the analytical results. Four sets of duplicate samples were collected and from each pair of samples, one sample was sent to the USGS NWQL and one sample was sent to the SDSU NGPWRRC Laboratory for analyses. The purpose of these duplicate samples was to assess the variability in analytical results between the USGS NWQL and the SDSU NGPWRRC Laboratory. One set of duplicate samples was collected, and both samples were submitted to the USGS NWQL. The purpose of this set of duplicate samples was to assess the precision of analytical results within the USGS NWQL. Data from the duplicate samples are presented in a following section.

Twenty-one sets of duplicate samples were collected, and both samples from each pair were submitted to the SDSU NGPWRRC Laboratory. For these 21 duplicate sets, one sample from each pair was disguised such that the laboratory was unable to associate the two samples of each duplicate pair. These duplicate samples are referred to as blind duplicates, and the purpose of these was to assess the precision of analytical results within the SDSU NGPWRRC Laboratory. Data from the blind duplicates are presented in a following section.

Generally, the duplicate samples collected during this study indicated that there is reasonable agreement between the analyses of the USGS NWQL and the SDSU NGPWRRC Laboratory. They also indicated that there is reasonable consistency within both the USGS NWQL and the SDSU NGPWRRC Laboratory.

\section{Screening Water-Quality Data}

Water-quality data for the screening sampling program were collected at six sites (fig. 93) during the period presented in this report. Information regarding station identification and location are presented in table 5. All wells used in the screening program are completed in the Warren aquifer. The water-quality data collected from the screening sampling program samples are presented in table 8 in the Supplemental Information section at the end of the report. Waterquality data collected through water year 1993 are presented for 32 screening sites in Carter (1995). Qualityassurance data collected from duplicate blind samples also are presented in table 8 . 


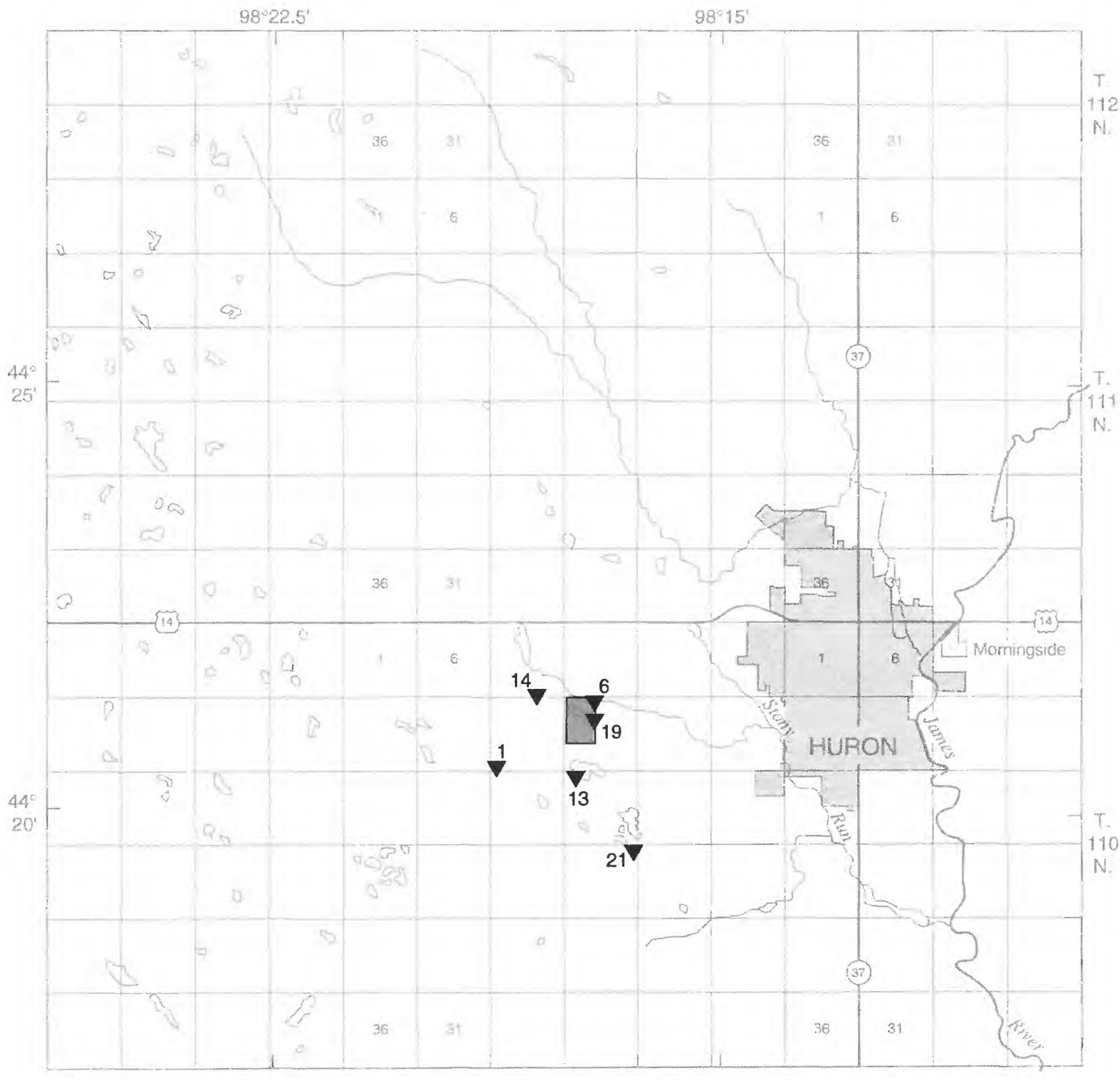

R. $63 \mathrm{~W}$.

Base from U.S. Geological Survey 1:100,000,

Huron planimetric map, 1985

City limit from Office of the City Engineer map, Huron, 1990
R. $62 \mathrm{~W}$.

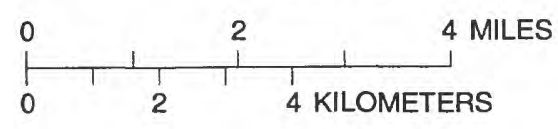

\section{EXPLANATION}

HURON WELL FIELD

$\nabla^{14}$ WATER-QUALITY SAMPLING SITE--Number corresponds to the middle number of the other identifier number in table 5

Figure 93. Location of screening water-quality sampling sites. 
Table 5. Wells used in screening water-quality program

[Other identifier: $\mathrm{CO}$, combination rig]

\begin{tabular}{ccc}
\hline Station identification number & USGS local number & Other identifier \\
\hline 442122098172002 & 110 N62W 9BABB & CO-06-90 \\
442124098181601 & 110 N62W 5DCCC & CO-14-90 \\
442002098185301 & 110 N62W 8CCCC & CO-01-90 \\
442110098172501 & 110 N62W 9BBDD & CO-19-90 \\
442032098172501 & 110 N62W16BBAA & CO-13-90 \\
441937098163001 & 110 N62W21AAAA & CO-21-90 \\
\hline
\end{tabular}

\section{Detailed Water-Quality Data}

Water-quality data for the detailed sampling program were collected at four sites within the study area (fig. 94). These samples represent the quality of untreated water (James River), treated water (water treatment plant), and ground water from the Warren aquifer (two wells). Information regarding site identification and location is presented in table 6 .

Water-quality data obtained from the detailed sampling program are presented in four tables (tables 9, 10, 11, and 12) in the Supplemental Information section. The physical properties, field parameters, bacteria counts, and concentrations of common ions, solids, nutrients, trace elements, radiometrics, and total organic carbon are presented in table 9. Quality-assurance data collected from duplicate and duplicate blind samples also are presented in table 9. In table 9,2 sigma refers to the 2 sigma precision estimate (2SPE), which is a measure of the error of the reported concentration. Generally, there is about 95 percent certainty that the true concentration for a sample is within the range of the reported value plus or minus the $2 \mathrm{SPE}$, with the lower part of that range bounded by zero.

Concentrations of herbicides are presented in table 10, and concentrations of organochlorine insecticides, gross polychlorinated biphenols (PCB's), and gross polychlorinated naphthalenes (PCN's) are presented in table 11. Concentrations of volatile organic compounds are presented in table 12 . Water-quality data collected through water year 1993 are presented for eight detailed sites in Carter (1995).

\section{Plume-Monitoring Water-Quality Data}

Water-quality data for the plume-monitoring sampling program were collected at 25 sites within the Huron well field (fig. 95). All samples for this sampling program were collected by SDSU field personnel and analyzed by the SDSU NGPWRRC Laboratory. Information regarding station identification and location are presented in table 7 . These sites were sampled during the period of injection of recharge water into the Warren aquifer during the summers of 1994 and 1995. All wells used in the plume-monitoring sampling program are completed in the Warren aquifer. The waterquality data collected from this sampling program are presented in table 13 in the Supplemental Information section. The difference between the recharge well and recharge well injectate should be noted. The waterquality data from the recharge well represents the aquifer water, and the data from the recharge well injectate represents treated water from Huron's water treatment plant before it is injected into the aquifer.

Table 6. Sites used in detailed water-quality sampling program

\begin{tabular}{llll}
\hline $\begin{array}{c}\text { Station identification } \\
\text { number }\end{array}$ & \multicolumn{1}{c}{ USGS local number } & \multicolumn{1}{c}{ Station name or other identifier } & $\begin{array}{c}\text { Sample } \\
\text { representation }\end{array}$ \\
\hline 442150098120601 & 110 N61W 6ACCD & James River at Morningside & Untreated water \\
442150098120602 & 110N61W 6ACCD2 & Huron Water Treatment Plant effluent & Treated water \\
442150098174401 & 110N62W 5ADDD & CO-05-90 & Warren aquifer \\
442111098173801 & 110N62W 9BBCD & CO-18-90 & Warren aquifer \\
\hline
\end{tabular}




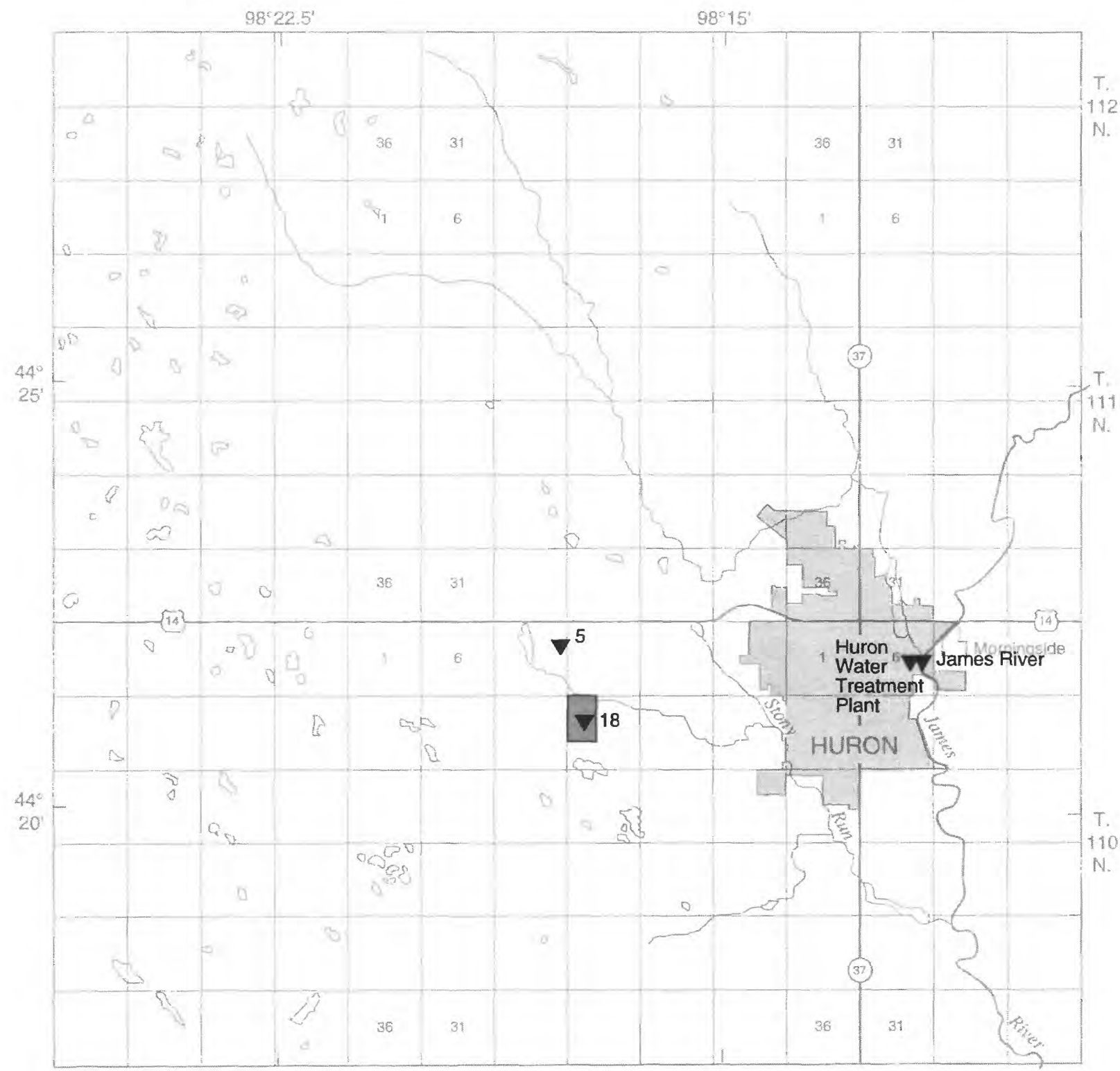

R. $63 \mathrm{~W}$.

A. $62 \mathrm{~W}$.

A. $61 \mathrm{~W}$.

Base from U.S. Geological Survey 1:100,000,

Huron planimetric map, 1985

City limit from Office of the City Engineer map, Huron, 1990

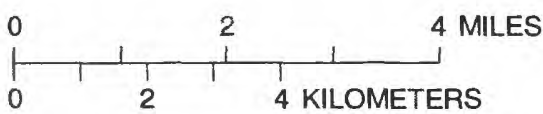

EXPLANATION

HURON WELL FIELD

$\nabla^{5}$ WATER-QUALITY SAMPLING SITE--Number corresponds to the middle number of the other identifier number in table 6

Figure 94. Location of detailed water-quality sampling sites. 


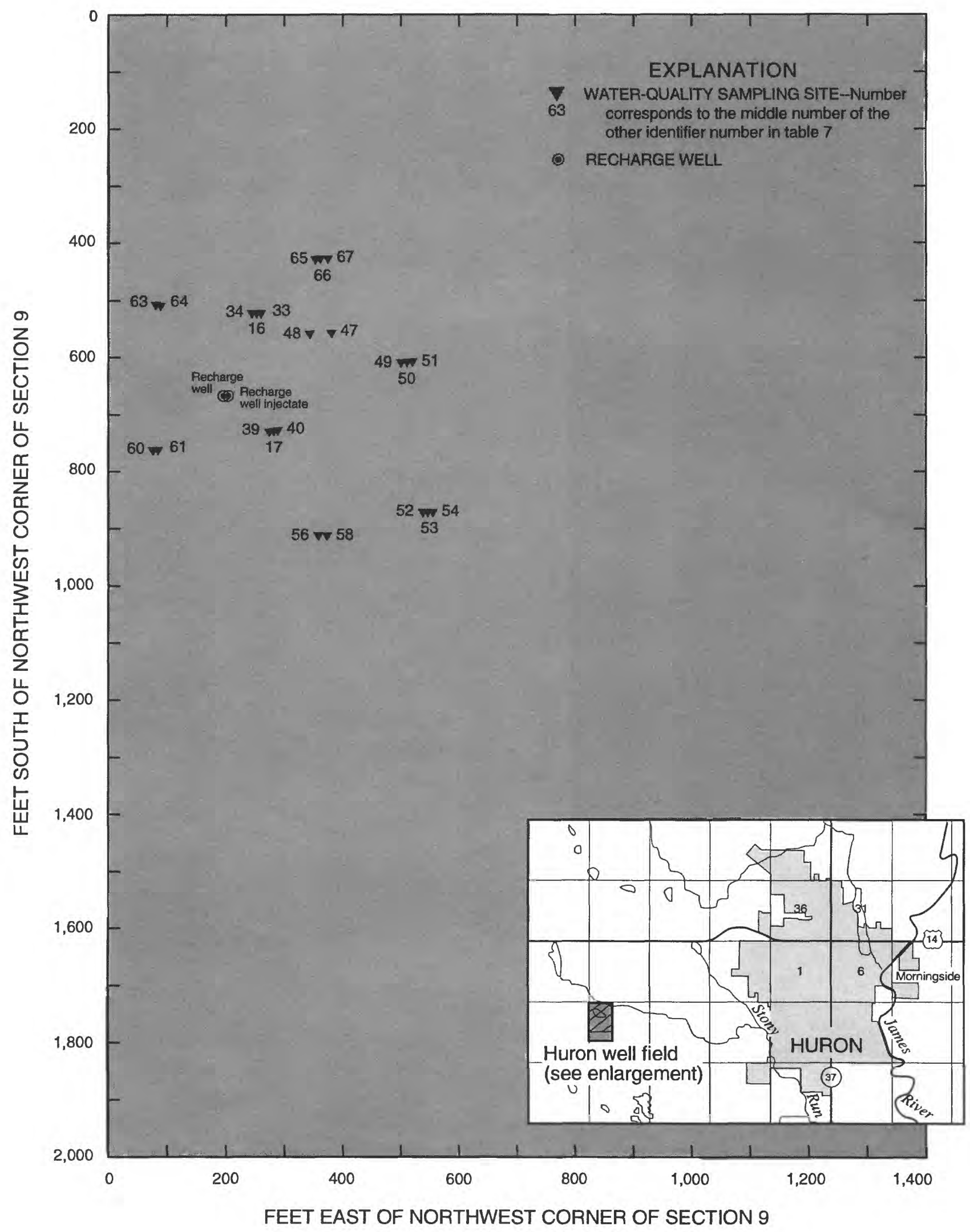

Figure 95. Location of plume-monitoring water-quality sampling sites in the Huron well field. 
Table 7. Sites used in plume-monitoring water-quality sampling program

\begin{tabular}{|c|c|c|}
\hline Station identification number & USGS local number & Other identifier \\
\hline 442119098173601 & 110N62W 9BBBA & CO-65-90 \\
\hline 442119098173602 & $110 \mathrm{~N} 62 \mathrm{~W} 9 \mathrm{BBBA} 2$ & $\mathrm{CO}-66-90$ \\
\hline 442119098173603 & $110 \mathrm{~N} 62 \mathrm{~W} 9 \mathrm{BBBA} 3$ & CO-67-90 \\
\hline 442118098174001 & 110N62W 9BBBC & CO-16-90 \\
\hline 442118098174002 & $110 \mathrm{~N} 62 \mathrm{~W} 9 \mathrm{BBBC} 2$ & $\mathrm{CO}-33-90$ \\
\hline 442118098174003 & $110 \mathrm{~N} 62 \mathrm{~W} 9 \mathrm{BBBC} 3$ & CO-34-90 \\
\hline 442117098173603 & 110N62W 9BBBD3 & $\mathrm{CO}-47-90$ \\
\hline 442117098173604 & 110N62W 9BBBD4 & $\mathrm{CO}-48-90$ \\
\hline 442117098173501 & 110N62W 9BBBD5 & $\mathrm{CO}-49-90$ \\
\hline 442117098173502 & 110N62W 9BBBD6 & CO-50-90 \\
\hline 442117098173503 & 110N62W 9BBBD7 & CO-51-90 \\
\hline 442115098173501 & $110 \mathrm{~N} 62 \mathrm{~W} 9 \mathrm{BBCA}$ & CO-52-90 \\
\hline 442115098173502 & $110 \mathrm{~N} 62 \mathrm{~W} 9 \mathrm{BBCA} 2$ & CO-53-90 \\
\hline 442115098173503 & 110N62W 9BBCA3 & $\mathrm{CO}-54-90$ \\
\hline 442117098174002 & $110 \mathrm{~N} 62 \mathrm{~W} 9 \mathrm{BBCB} 2$ & CO-39-90 \\
\hline 442117098174003 & 110N62W 9BBCB3 & $\mathrm{CO}-40-90$ \\
\hline 442117098174001 & $110 \mathrm{~N} 62 \mathrm{~W} 9 \mathrm{BBCB} 8$ & $\mathrm{CO}-17-90$ \\
\hline 442115098174202 & $110 \mathrm{~N} 62 \mathrm{~W} 9 \mathrm{BBCB} 9$ & CO-63-90 \\
\hline 442115098174203 & $110 \mathrm{~N} 62 \mathrm{~W} 9 \mathrm{BBCB} 10$ & CO-64-90 \\
\hline 442115098173903 & $110 \mathrm{~N} 62 \mathrm{~W} 9 \mathrm{BBCB} 13$ & CO-58-90 \\
\hline 442115098173901 & 110N62W 9BBCB14 & CO-56-90 \\
\hline 442117098174008 & 110N62W 9BBCB15 & Recharge well \\
\hline 442117098174009 & $110 \mathrm{~N} 62 \mathrm{~W} 9 \mathrm{BBCB} 16$ & Recharge well injectate \\
\hline 442113098174202 & $110 \mathrm{~N} 62 \mathrm{~W} 9 \mathrm{BBCC} 2$ & CO-60-90 \\
\hline 442113098174203 & $110 \mathrm{~N} 62 \mathrm{~W} 9 \mathrm{BBCC} 3$ & CO-61-90 \\
\hline
\end{tabular}

\section{REFERENCES}

Carter, J.M., 1995, Hydrologic data through 1993 for the Huron Project of the High Plains Ground-Water Demonstration Program: U.S. Geological Survey Open-File Report 95-313, 151 p.

Flint, R.F., 1955, Pleistocene geology of eastern South Dakota: U.S. Geological Survey Professional Paper 262, $173 \mathrm{p}$.

Howells, L.W., and Stephens, J.C., 1968, Geology and water resources of Beadle County, South Dakota: Part II, Water resources: South Dakota Geological Survey Bulletin 18, $65 \mathrm{p}$.

Schaefer, V.R., DeBoer, D.E., and Emmons, P.J., 1990, Huron Groundwater Recharge Demonstration Project of the High Plains Groundwater Demonstration Program, Plan of Development: South Dakota State University, Brookings, South Dakota.

Steece, F.V., and Howells, L.W., 1965, Geology and groundwater supplies in Sanborn County, South Dakota: South Dakota Geological Survey Bulletin 17, 182 p.

U.S. Department of Commerce, 1993-95, Local climatological data for Huron, South Dakota, monthly summary: Asheville, North Carolina, October 1993 to September 1995 (published monthly).

U.S. Geological Survey, 1987-95, Water resources data for South Dakota, Water years 1986-1994: U.S.

Geological Survey Water Data Reports SD-86-1 to SD-94-1 (published annually). 
SUPPLEMENTAL INFORMATION 
Table 8. Water-quality data obtained from screening samples

[Agency collecting or analyzing sample: USGS, U.S. Geological Survey; SDSU, South Dakota State University. $\mu$ S/cm, microsiemens per centimeter; $\mathrm{mg} / \mathrm{L}$, milligrams per liter; $\mathrm{mV}$, millivolt; $\mathrm{mL}$, milliliter; $\mu \mathrm{g} / \mathrm{L}$, micrograms per liter; pci/L, deg, degrees; IT, incremental titration; --, no data]

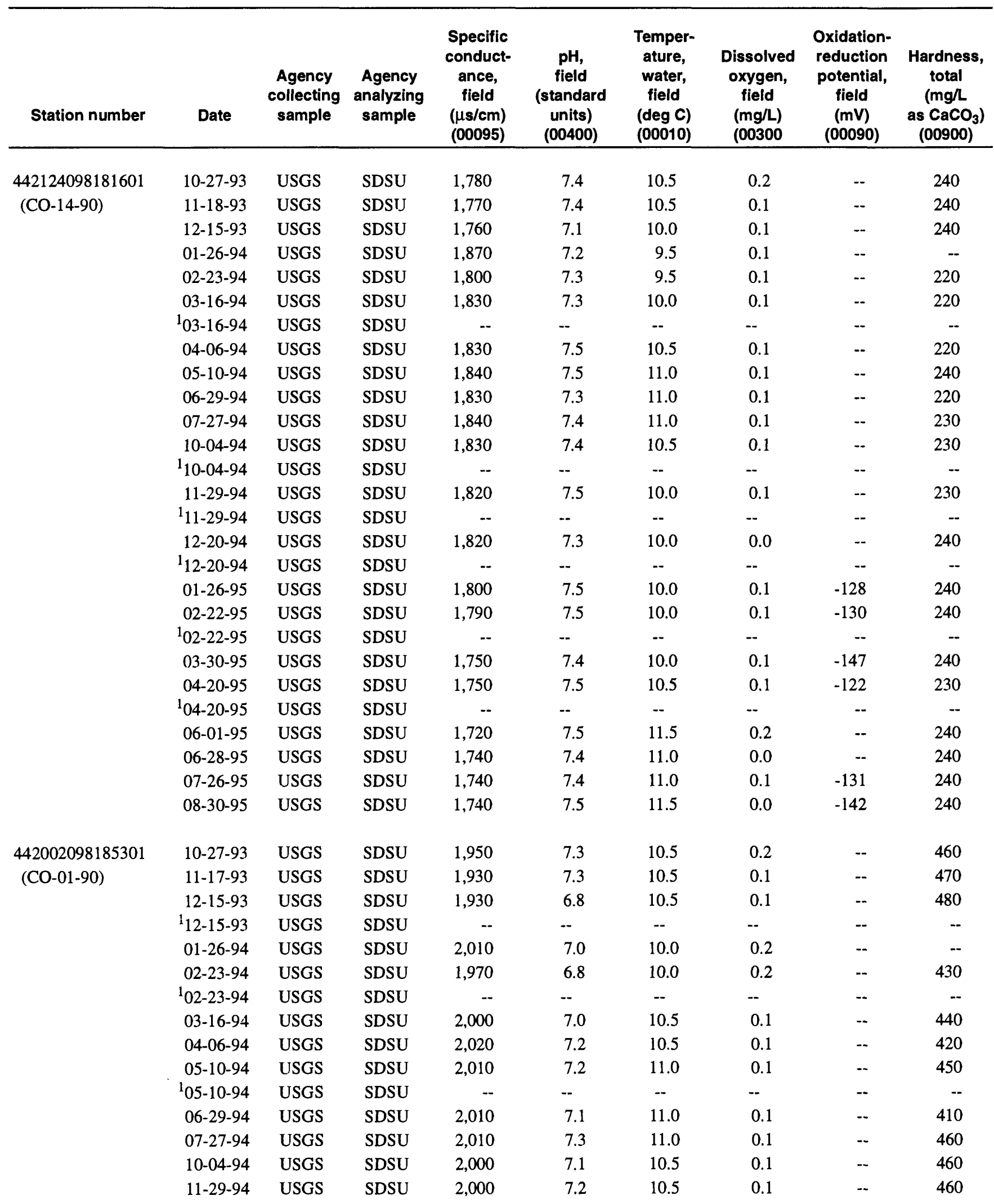




\begin{tabular}{|c|c|c|c|c|c|c|c|c|c|c|}
\hline 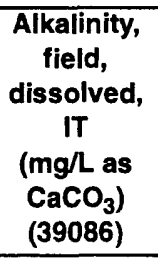 & $\begin{array}{c}\text { Calcium, } \\
\text { dissolved } \\
\text { (mg/L } \\
\text { as Ca) } \\
(00915) \\
\end{array}$ & $\begin{array}{l}\text { Magne- } \\
\text { sium, } \\
\text { dissolved } \\
\text { (mg/L } \\
\text { as Mg) } \\
(00925) \\
\end{array}$ & $\begin{array}{c}\text { Sodium, } \\
\text { dissolved } \\
\text { (mg/L } \\
\text { as Na) } \\
(00930) \\
\end{array}$ & $\begin{array}{l}\text { Sodium } \\
\text { adsorp- } \\
\text { tion } \\
\text { ratio } \\
\text { (00931) } \\
\end{array}$ & $\begin{array}{c}\text { Bicar- } \\
\text { bonate, } \\
\text { field, } \\
\text { dissolved } \\
\left(\mathrm{mg}^{\prime} \mathrm{L} \text { as }\right. \\
\left.\mathrm{HCO}_{3}\right) \\
(00453) \\
\end{array}$ & $\begin{array}{c}\text { Carbonate, } \\
\text { field, } \\
\text { dissolved } \\
(\mathrm{mg} / \mathrm{L} \\
\left.\text { as } \mathrm{CO}_{3}\right) \\
(00452) \\
\end{array}$ & $\begin{array}{c}\text { Sulfate, } \\
\text { dissolved } \\
(\mathrm{mg} / \mathrm{L} \\
\left.\text { as } \mathrm{SO}_{4}\right) \\
(00945)\end{array}$ & $\begin{array}{c}\text { Chloride, } \\
\text { dissolved } \\
\text { (mg/L } \\
\text { as Cl) } \\
(00940) \\
\end{array}$ & $\begin{array}{c}\text { Iron, } \\
\text { dissolved } \\
(\mu \mathrm{g} / \mathrm{L} \\
\text { as } \mathrm{Fe}) \\
(01046) \\
\end{array}$ & $\begin{array}{c}\text { Manga- } \\
\text { nese, } \\
\text { dissolved } \\
(\mu \mathrm{g} / \mathrm{L} \\
\text { as Mn) } \\
(01056) \\
\end{array}$ \\
\hline 416 & 65 & 18 & 320 & 9 & 507 & 0 & 470 & 34 & 2,800 & 330 \\
\hline 462 & 65 & 19 & 320 & 9 & 563 & 0 & 460 & 35 & 2,800 & 340 \\
\hline 457 & 65 & 18 & 330 & 9 & 557 & 0 & 490 & 35 & 2,900 & 340 \\
\hline 470 & -- & 17 & -- & -- & 573 & 0 & -- & -- & -- & -- \\
\hline 444 & 56 & 19 & 320 & 9 & 541 & 0 & 510 & 33 & 2,800 & 360 \\
\hline 452 & 58 & 19 & 310 & 9 & 551 & 0 & 510 & 34 & 2,800 & 350 \\
\hline -- & 83 & 20 & 320 & -- & -- & -- & 490 & 34 & 2,800 & 350 \\
\hline 448 & 58 & 18 & 310 & 9 & 546 & 0 & 430 & 34 & 2,800 & 360 \\
\hline 450 & 67 & 18 & 310 & 9 & 549 & 0 & 460 & 35 & 2,900 & 340 \\
\hline 490 & 60 & 17 & 310 & 9 & 598 & 0 & 480 & 36 & 2,900 & 320 \\
\hline 454 & 64 & 17 & 310 & 9 & 554 & 0 & 470 & 35 & 2,800 & 350 \\
\hline 500 & 66 & 17 & 340 & 10 & -- & 0 & 440 & 35 & 2,600 & 330 \\
\hline -- & 65 & 18 & 340 & -- & -- & -- & 440 & 34 & 2,600 & 320 \\
\hline 442 & 64 & 17 & 320 & 9 & 539 & 0 & 450 & 34 & 2,800 & 350 \\
\hline -- & 64 & 18 & 320 & 9 & -- & -- & 450 & 34 & 2,700 & 350 \\
\hline 460 & 66 & 17 & 320 & 9 & 561 & 0 & 450 & 35 & 2,700 & 320 \\
\hline -- & 66 & 17 & 320 & -- & -- & -- & 460 & 35 & 2,700 & 320 \\
\hline 450 & 65 & 18 & 320 & 9 & 549 & 0 & 460 & 35 & 2,700 & 340 \\
\hline 444 & 66 & 18 & 310 & 9 & 542 & 0 & 470 & 34 & 2,800 & 340 \\
\hline -- & 66 & 18 & 310 & -- & -- & -- & 470 & 34 & 2,700 & 340 \\
\hline 444 & 66 & 18 & 320 & 9 & 542 & 0 & 470 & 33 & 2,900 & 360 \\
\hline 466 & 65 & 17 & 310 & 9 & 569 & 0 & 470 & 34 & 2,900 & 330 \\
\hline .- & 66 & 17 & 310 & -- & -- & -- & 470 & 35 & 2,900 & 330 \\
\hline 440 & 66 & 18 & 320 & 9 & 537 & 0 & 460 & 34 & 3,000 & 350 \\
\hline 440 & 68 & 18 & 310 & 9 & 537 & 0 & 480 & 34 & 2,900 & 340 \\
\hline 438 & 67 & 18 & 320 & 9 & 453 & 0 & 460 & 34 & 2,900 & 350 \\
\hline 428 & 65 & 19 & 300 & 8 & 522 & 0 & 460 & 35 & 2,200 & 350 \\
\hline 414 & 120 & 40 & 270 & 5 & 505 & 0 & 550 & 38 & 30 & 1,700 \\
\hline 462 & 120 & 41 & 280 & 6 & 563 & 0 & 570 & 40 & 40 & 1,700 \\
\hline 464 & 120 & 40 & 290 & 6 & 566 & 0 & 600 & 39 & 20 & 1,800 \\
\hline- & 120 & 40 & 280 & .- & -. & -. & 570 & 39 & 20 & 1,700 \\
\hline 472 & -- & 39 & -- & -- & 575 & 0 & -- & -. & -. & -. \\
\hline 456 & 110 & 41 & 270 & 6 & 556 & 0 & 650 & 40 & 20 & 1,800 \\
\hline -- & 100 & 42 & 280 & -- & -- & -- & 650 & 40 & 20 & 1,800 \\
\hline 470 & 110 & 42 & 280 & 6 & 573 & 0 & 610 & 41 & 20 & 1,800 \\
\hline 484 & 100 & 40 & 280 & 6 & 590 & 0 & 540 & 41 & 20 & 1,800 \\
\hline 452 & 120 & 39 & 280 & 6 & 552 & 0 & 580 & 42 & 20 & 1,700 \\
\hline -- & 120 & 39 & 280 & -- & -- & -- & 560 & 42 & 20 & 1,700 \\
\hline 452 & 100 & 39 & 280 & 6 & 552 & 0 & 580 & 42 & 40 & 1,600 \\
\hline 500 & 120 & 38 & 270 & 6 & 610 & 0 & 560 & 41 & 30 & 1,700 \\
\hline 456 & 120 & 38 & 290 & 6 & -- & 0 & 560 & 41 & 30 & 1,700 \\
\hline 454 & 120 & 39 & 280 & 6 & 554 & 0 & 560 & 40 & 50 & 1,800 \\
\hline
\end{tabular}


Table 8. Water-quality data obtained from screening samples-Continued

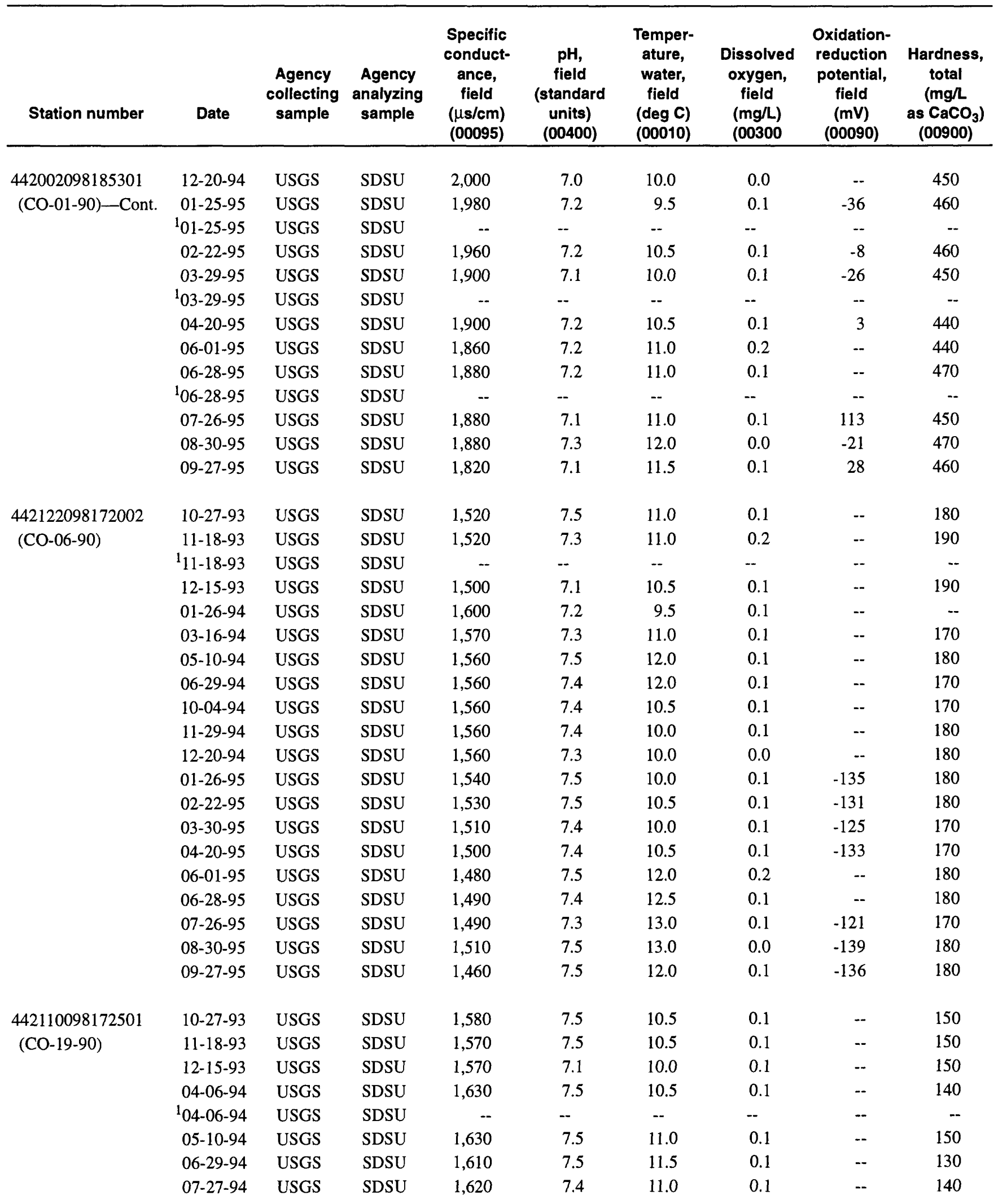




\begin{tabular}{|c|c|c|c|c|c|c|c|c|c|c|}
\hline $\begin{array}{l}\text { Alkalinity, } \\
\text { field, } \\
\text { dissolved, } \\
\text { IT } \\
\left(\mathrm{mg}^{\prime} \mathrm{L} \text { as }\right. \\
\left.\mathrm{CaCO}_{3}\right) \\
(39086)\end{array}$ & $\begin{array}{c}\text { Calcium, } \\
\text { dissolved } \\
\text { (mg/L } \\
\text { as Ca) } \\
(00915)\end{array}$ & $\begin{array}{l}\text { Magne- } \\
\text { sium, } \\
\text { dissolved } \\
\text { (mg/L } \\
\text { as Mg) } \\
(00925)\end{array}$ & $\begin{array}{c}\text { Sodium, } \\
\text { dissolved } \\
\text { (mg/L } \\
\text { as } \mathrm{Na}) \\
(00930)\end{array}$ & $\begin{array}{l}\text { Sodium } \\
\text { adsorp- } \\
\text { tion } \\
\text { ratio } \\
(00931)\end{array}$ & $\begin{array}{c}\text { Bicar- } \\
\text { bonate, } \\
\text { field, } \\
\text { dissolved } \\
\left(\mathrm{mg}^{2} / \text { as }\right. \\
\left.\mathrm{HCO}_{3}\right) \\
(00453)\end{array}$ & $\begin{array}{l}\text { Carbonate, } \\
\text { field, } \\
\text { dissolved } \\
\text { (mg/L } \\
\left.\text { as } \mathrm{CO}_{3}\right) \\
(00452)\end{array}$ & $\begin{array}{c}\text { Sulfate, } \\
\text { dissolved } \\
\left(\mathrm{mg}^{2} \mathbf{L}\right. \\
\left.\text { as } \mathrm{SO}_{4}\right) \\
(00945)\end{array}$ & $\begin{array}{c}\text { Chloride, } \\
\text { dissolved } \\
\text { (mg/L } \\
\text { as Cl) } \\
(00940)\end{array}$ & $\begin{array}{c}\text { Iron, } \\
\text { dissolved } \\
(\mu \mathrm{g} / \mathrm{L} \\
\text { as Fe) } \\
(01046)\end{array}$ & $\begin{array}{c}\text { Manga- } \\
\text { nese, } \\
\text { dissolved } \\
(\mu g / L \\
\text { as Mn) } \\
(01056)\end{array}$ \\
\hline -- & 120 & 38 & 290 & -- & -- & -- & 590 & 42 & 30 & 1,700 \\
\hline 468 & 120 & 40 & 270 & 5 & 571 & 0 & 570 & 40 & 20 & 1,700 \\
\hline 468 & 120 & 39 & 270 & 6 & 571 & 0 & 550 & 40 & 30 & 1,800 \\
\hline -. & 120 & 39 & 270 & -- & -. & -- & 560 & 40 & 30 & 1,700 \\
\hline 446 & 110 & 37 & 270 & 6 & 544 & 0 & 590 & 41 & 20 & 1,700 \\
\hline 438 & 110 & 39 & 280 & 6 & 534 & 0 & 560 & 40 & 20 & 1,700 \\
\hline 440 & 120 & 41 & 270 & 6 & 537 & 0 & 560 & 40 & 680 & 1,800 \\
\hline 460 & 120 & 41 & 290 & 6 & 561 & 0 & 560 & 41 & 20 & 1,700 \\
\hline 440 & 49 & 13 & 270 & 9 & 536 & 0 & 310 & 34 & 1,900 & 500 \\
\hline 504 & 51 & 15 & 290 & 9 & 614 & 0 & 280 & 35 & 2,000 & 510 \\
\hline -. & 51 & 14 & 290 & -- & -- & -- & 280 & 35 & 2,000 & 520 \\
\hline 558 & 52 & 14 & 290 & 9 & 680 & 0 & 310 & 35 & 2,000 & 510 \\
\hline 478 & -- & 13 & -- & -- & 583 & 0 & -- & -- & -- & -- \\
\hline 496 & 45 & 14 & 280 & 9 & 605 & 0 & 300 & 35 & 2,000 & 510 \\
\hline 470 & 50 & 13 & 280 & 9 & 574 & 0 & 290 & 35 & 1,900 & 480 \\
\hline 492 & 49 & 13 & 280 & 9 & 600 & 0 & 290 & 36 & 2,000 & 500 \\
\hline 486 & 50 & 12 & 280 & 9 & 593 & 0 & 290 & 35 & 1,900 & 460 \\
\hline 464 & 51 & 12 & 290 & 9 & 566 & 0 & 290 & 34 & 1,900 & 470 \\
\hline 486 & 51 & 13 & 280 & 9 & 593 & 0 & 270 & 34 & 2,000 & 460 \\
\hline 462 & 50 & 12 & 280 & 9 & 564 & 0 & 290 & 35 & 2,000 & 480 \\
\hline 462 & 49 & 13 & 270 & 9 & 564 & 0 & 270 & 36 & 600 & 490 \\
\hline 476 & 49 & 13 & 300 & 10 & 581 & 0 & 290 & 36 & 1,900 & 500 \\
\hline 474 & 40 & 12 & 310 & 11 & 578 & 0 & 310 & 35 & 1,500 & 320 \\
\hline 508 & 41 & 13 & 320 & 11 & 619 & 0 & 270 & 37 & 1,600 & 340 \\
\hline 536 & 40 & 11 & 320 & 12 & 653 & 0 & 330 & 37 & 1,500 & 340 \\
\hline 534 & 36 & 12 & 320 & 12 & 651 & 0 & 280 & 36 & 1,500 & 350 \\
\hline -- & 36 & 12 & 310 & -- & -- & - & 270 & 36 & 1,500 & 340 \\
\hline 516 & 41 & 11 & 300 & 11 & 630 & 0 & 290 & 37 & 1,600 & 320 \\
\hline 546 & 36 & 10 & 310 & 12 & 666 & 0 & 300 & 36 & 1,500 & 310 \\
\hline 510 & 39 & 11 & 310 & 11 & 622 & 0 & 290 & 36 & 1,500 & 330 \\
\hline
\end{tabular}


Table 8. Water-quality data obtained from screening samples-Continued

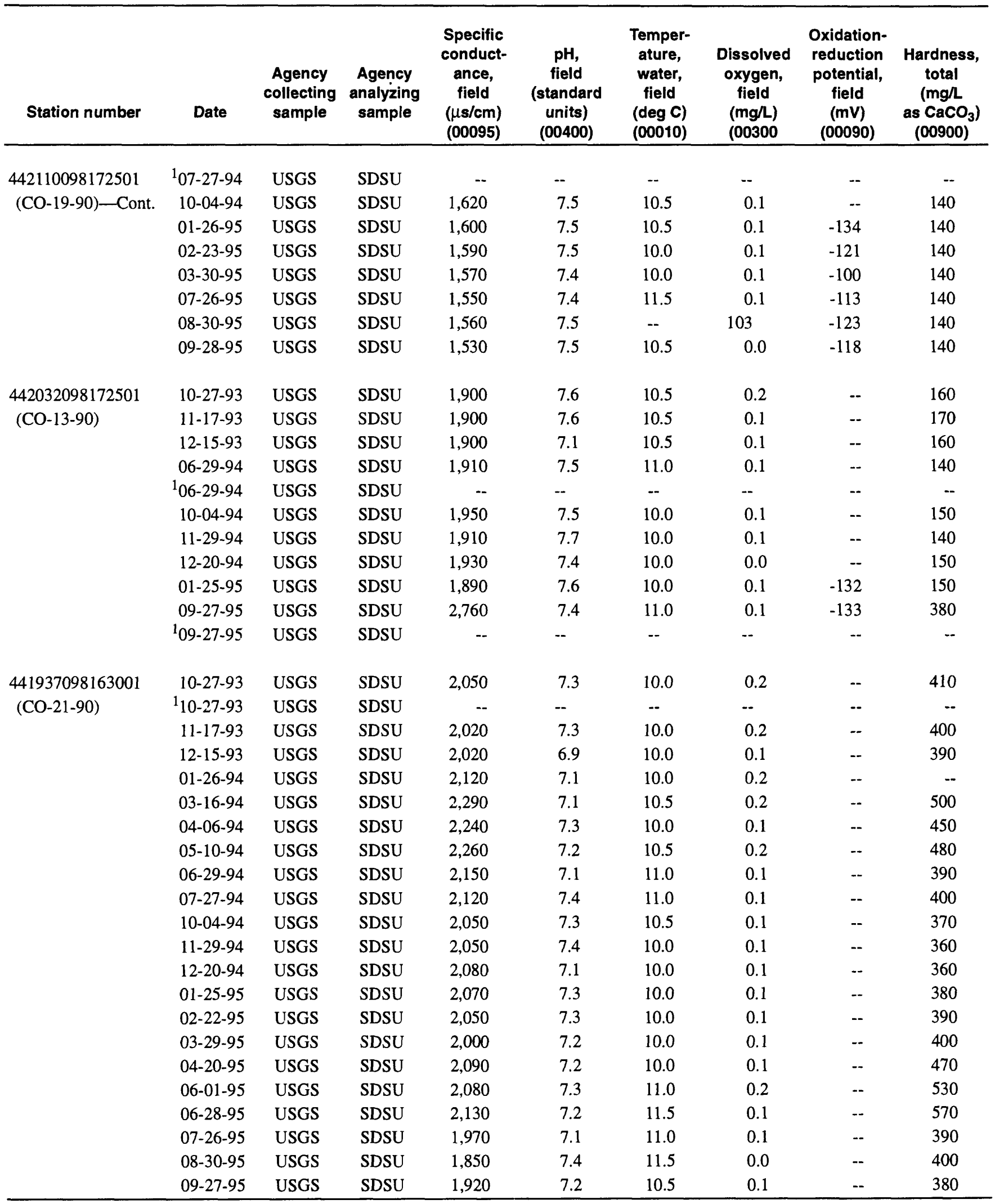

${ }^{1}$ Indicates duplicate blind sample for quality-assurance purposes. 


\begin{tabular}{|c|c|c|c|c|c|c|c|c|c|c|}
\hline $\begin{array}{l}\text { Alkalinity, } \\
\text { field, } \\
\text { dissolved, } \\
\text { IT } \\
\text { (mg/l as } \\
\mathrm{CaCO}_{3} \text { ) } \\
(39086)\end{array}$ & $\begin{array}{c}\text { Calcium, } \\
\text { dissolved } \\
\text { (mg/L } \\
\text { as Ca) } \\
(00915)\end{array}$ & $\begin{array}{l}\text { Magne- } \\
\text { sium, } \\
\text { dissolved } \\
\text { (mg/L } \\
\text { as Mg) } \\
(00925)\end{array}$ & $\begin{array}{c}\text { Sodium, } \\
\text { dissolved } \\
\text { (mg/L } \\
\text { as } \mathrm{Na}) \\
(00930)\end{array}$ & $\begin{array}{l}\text { Sodium } \\
\text { adsorp- } \\
\text { tion } \\
\text { ratio } \\
\text { (00931) }\end{array}$ & $\begin{array}{c}\text { Bicar- } \\
\text { bonate, } \\
\text { field, } \\
\text { dissolved } \\
\text { (mglL as } \\
\left.\mathrm{HCO}_{3}\right) \\
(00453)\end{array}$ & $\begin{array}{l}\text { Carbonate, } \\
\text { field, } \\
\text { dissolved } \\
(\mathrm{mg} / \mathrm{L} \\
\left.\text { as } \mathrm{CO}_{3}\right) \\
(00452)\end{array}$ & $\begin{array}{l}\text { Sulfate, } \\
\text { dissolved } \\
\text { (mg/L } \\
\left.\text { as SO }{ }_{4}\right) \\
(00945)\end{array}$ & $\begin{array}{c}\text { Chloride, } \\
\text { dissolved } \\
\text { (mg/L } \\
\text { as Cl) } \\
(00940)\end{array}$ & $\begin{array}{c}\text { Iron, } \\
\text { dissolved } \\
(\mu g / L \\
\text { as Fe) } \\
(01046)\end{array}$ & $\begin{array}{c}\text { Manga- } \\
\text { nese, } \\
\text { dissolved } \\
(\mu g / 2 \\
\text { as Mn) } \\
(01056)\end{array}$ \\
\hline -.. & 48 & 10 & 300 & .. & -- & -- & 280 & 36 & 1,500 & 330 \\
\hline 508 & 40 & 9.8 & 340 & 12 & -- & 0 & 280 & 36 & 1,400 & 310 \\
\hline 498 & 39 & 11 & 330 & 12 & 608 & 0 & 300 & 37 & 1,400 & 320 \\
\hline 514 & 40 & 10 & 310 & 11 & 627 & -- & 290 & 36 & 1,500 & 320 \\
\hline 518 & 39 & 10 & 310 & 12 & 632 & 0 & 280 & 37 & 1,500 & 330 \\
\hline 500 & 38 & 10 & 320 & 12 & 610 & 0 & 290 & 37 & 1,500 & 300 \\
\hline 474 & 38 & 11 & 300 & 11 & 578 & 0 & 280 & 36 & 980 & 310 \\
\hline 516 & 38 & 11 & 320 & 12 & 630 & 0 & 290 & 37 & 1,400 & 380 \\
\hline 464 & 41 & 13 & 380 & 13 & 566 & 0 & 470 & 35 & 2,100 & 180 \\
\hline 510 & 43 & 15 & 390 & 13 & 622 & 0 & 480 & 37 & 2,100 & 190 \\
\hline 512 & 43 & 14 & 400 & 14 & 624 & 0 & 500 & 37 & 2,100 & 190 \\
\hline 516 & 34 & 12 & 390 & 15 & 630 & 0 & 440 & 38 & 1,900 & 160 \\
\hline -- & 34 & 11 & 380 & -- & -- & -- & 450 & 39 & 1,900 & 160 \\
\hline 504 & 40 & 11 & 400 & 14 & -- & 0 & 450 & 37 & 1,900 & 170 \\
\hline 498 & 38 & 12 & 380 & 14 & 608 & 0 & 440 & 36 & 1,900 & 180 \\
\hline 548 & 41 & 12 & 380 & 14 & 669 & 0 & 460 & 39 & 1,100 & 410 \\
\hline 492 & 39 & 12 & 380 & 14 & 600 & 0 & 390 & 40 & 1,900 & 170 \\
\hline 416 & 100 & 31 & 560 & 12 & 508 & 0 & 1,100 & 47 & 4,400 & 450 \\
\hline -- & 100 & 32 & 570 & -- & -- & -- & 1,100 & 47 & 4,500 & 450 \\
\hline 414 & 100 & 37 & 320 & 7 & 505 & 0 & 640 & 36 & 480 & 720 \\
\hline -. & 100 & 37 & 320 & .- & -- & .- & 630 & 37 & 480 & 720 \\
\hline 432 & 100 & 35 & 330 & 7 & 527 & 0 & 650 & 39 & 550 & 770 \\
\hline 468 & 100 & 34 & 340 & 7 & 571 & 0 & 660 & 38 & 570 & 790 \\
\hline 456 & -- & 34 & -- & -- & 556 & 0 & -- & -- & -- & -- \\
\hline 430 & 120 & 51 & 320 & 6 & 524 & 0 & 900 & 45 & 430 & 790 \\
\hline 470 & 110 & 46 & 320 & 7 & 573 & 0 & 650 & 43 & 460 & 710 \\
\hline 428 & 120 & 45 & 320 & 6 & 522 & 0 & 730 & 44 & 460 & 660 \\
\hline 502 & 93 & 39 & 330 & 7 & 613 & 0 & 660 & 41 & 470 & 640 \\
\hline 448 & 100 & 34 & 320 & 7 & 547 & 0 & 640 & 40 & 540 & 740 \\
\hline 398 & 97 & 32 & 350 & 8 & 486 & 0 & 600 & 38 & 500 & 740 \\
\hline 464 & 93 & 30 & 350 & 8 & 566 & 0 & 610 & 37 & 610 & 870 \\
\hline 458 & 95 & 31 & 330 & 7 & 559 & 0 & 630 & 38 & 530 & 780 \\
\hline 404 & 99 & 33 & 340 & 8 & 493 & 0 & 630 & 39 & 480 & 820 \\
\hline 440 & 100 & 33 & 320 & 7 & 537 & 0 & 620 & 38 & 470 & 810 \\
\hline 428 & 100 & 34 & 330 & 7 & 522 & 0 & 600 & 39 & 460 & 880 \\
\hline 410 & 120 & 42 & 320 & 6 & 500 & 0 & 700 & 41 & 350 & 710 \\
\hline 414 & 130 & 49 & 300 & 6 & 505 & 0 & 760 & 43 & 300 & 580 \\
\hline 408 & 140 & 53 & 310 & 6 & 564 & 0 & 740 & 45 & 320 & 550 \\
\hline 404 & 98 & 34 & 320 & 7 & 493 & 0 & 620 & 39 & 430 & 640 \\
\hline 388 & 100 & 35 & 210 & 4 & 473 & 0 & 610 & 38 & 460 & 700 \\
\hline 436 & 97 & 33 & 340 & 8 & 532 & 0 & 600 & 39 & 480 & 700 \\
\hline
\end{tabular}


Table 9. Physical properties and concentrations of inorganic constituents, radioactive nuclides, and total organic carbon obtained from detailed samples

[Agency collecting or analyzing sample: USGS, U.S. Geological Survey; SDSU, South Dakota State University; NWQL, National Water Quality Laboratory; SDDHL, South Dakota Department of Health Laboratory. $\mu \mathrm{S} / \mathrm{cm}$, microsiemens per centimeter; $\mathrm{mg} / \mathrm{L}$, milligrams per liter; mm, millimeter; $\mathrm{mV}$, millivolt; $\mathrm{mL}$, milliliter; $\mu \mathrm{g} / \mathrm{L}$, micrograms per liter; pci/L, picocuries per liter; deg, degrees; FET, fixed end point titration; IT, incremental titration; NTU, nephelometric turbidity units; $\mu \mathrm{m}-\mathrm{mf}$, micrometer-membrane filter; cols, colonies; <, less than; --, no data]

\begin{tabular}{|c|c|c|c|c|c|c|c|c|c|c|}
\hline $\begin{array}{l}\text { Station number } \\
\text { (other identifier) }\end{array}$ & Date & $\begin{array}{l}\text { Agency } \\
\text { collecting } \\
\text { sample }\end{array}$ & $\begin{array}{c}\text { Agency } \\
\text { analyzing } \\
\text { sample }\end{array}$ & $\begin{array}{c}\text { Specific } \\
\text { conduct- } \\
\text { ance, } \\
\text { field } \\
(\mu S / \mathrm{cm}) \\
(00095)\end{array}$ & $\begin{array}{c}\mathrm{pH}, \\
\text { field } \\
\text { (standard } \\
\text { units) } \\
(00400) \\
\end{array}$ & $\begin{array}{l}\text { Temper- } \\
\text { ature, } \\
\text { air, } \\
\text { field } \\
\text { (deg C) } \\
(00020)\end{array}$ & $\begin{array}{l}\text { Temper- } \\
\text { ature, } \\
\text { water, } \\
\text { field } \\
(\operatorname{deg} C) \\
(00010) \\
\end{array}$ & $\begin{array}{c}\text { Turbidity, } \\
\text { field } \\
\text { (NTU) } \\
(00076) \\
\end{array}$ & $\begin{array}{c}\text { Baro- } \\
\text { metric } \\
\text { pressure, } \\
\text { field } \\
(\mathrm{mm} \text { of } \mathrm{Hg}) \\
(00025)\end{array}$ & $\begin{array}{c}\text { Dissolved } \\
\text { oxygen, } \\
\text { field } \\
(\mathrm{mg} / \mathrm{L}) \\
(00300) \\
\end{array}$ \\
\hline \multirow{8}{*}{$\begin{array}{l}442150098120601 \\
\text { (James River at } \\
\text { Morningside) }\end{array}$} & $03-22-94$ & USGS & NWQL & 490 & 7.7 & 18.0 & 6.0 & 29 & 604 & 8.5 \\
\hline & $03-22-94$ & USGS & SDDHL & -- & -- & -- & -- & -- & -- & -. \\
\hline & $05-02-94$ & USGS & NWQL & 897 & 8.1 & 10.0 & 8.0 & 3.0 & 768 & 10.9 \\
\hline & $05-02-94$ & USGS & SDDHL & -- & -- & -- & -- & -- & -- & -- \\
\hline & 05-24-94 & USGS & NWQL & 1,120 & 7.8 & 15.5 & 23.0 & 17 & 725 & 7.0 \\
\hline & $05-24-94$ & USGS & SDDHL & -- & -- & -- & -- & -- & -- & -- \\
\hline & $06-28-94$ & USGS & NWQL & 1,040 & 8.1 & 68.0 & 22.5 & 22 & 722 & 6.4 \\
\hline & $06-28-94$ & USGS & SDDHL & -- & -- & -- & -- & -- & -- & -- \\
\hline \multirow{19}{*}{$\begin{array}{l}442150098120602 \\
\text { (Huron Water } \\
\text { Treatment Plant } \\
\text { effluent) }\end{array}$} & $03-22-94$ & USGS & NWQL & 702 & 9.3 & 16.0 & 5.0 & -- & 604 & 10.6 \\
\hline & $03-22-94$ & USGS & SDDHL & -. & -- & -- & -- & -- & -- & -- \\
\hline & $05-02-94$ & USGS & NWQL & 938 & 9.0 & 16.0 & 10.5 & 0.20 & 768 & 9.6 \\
\hline & 05-02-94 & USGS & SDDHL & -- & -- & -- & -- & -- & -- & -- \\
\hline & $05-24-94$ & USGS & NWQL & 916 & 8.6 & 24.5 & 22.5 & 0.90 & 725 & 7.2 \\
\hline & $05-24-94$ & USGS & SDDHL & -- & -- & -- & -- & -- & -- & -- \\
\hline & 06-28-94 & USGS & NWQL & 784 & 8.9 & 20.0 & 24.0 & 0.30 & 724 & 6.6 \\
\hline & $06-28-94$ & USGS & SDDHL & -- & -- & -- & -- & -. & -- & -- \\
\hline & $07-26-94$ & USGS & NWQL & 825 & 9.1 & 12.5 & 24.0 & -- & 728 & 6.3 \\
\hline & $07-26-94$ & USGS & SDDHL & -- & -- & -- & -- & -- & -- & -- \\
\hline & $10-26-94$ & USGS & NWQL & 900 & 8.7 & 2.5 & 11.0 & -- & 729 & 10.3 \\
\hline & $10-26-94$ & USGS & SDDHL & -- & -- &.- & -- & -- & -- & -- \\
\hline & $04-24-95$ & USGS & SDSU & 781 & 9.0 & -- & 9.0 & -- & -- & 10.8 \\
\hline & $04-24-95$ & USGS & NWQL & 771 & 9.0 & 15.5 & 9.0 & -- & 753 & 10.8 \\
\hline & 04-24-95 & USGS & NWQL & -- & -- & -- & -- & -- & -- & -- \\
\hline & $07-06-95$ & USGS & NWQL & 817 & 9.0 & 18.0 & 22.0 & -- & 728 & 7.4 \\
\hline & 07-06-95 & USGS & SDDHL & -- & -- & -- & -- & -- & -- & -- \\
\hline & $08-21-95$ & USGS & NWQL & 678 & 8.9 & 24.0 & 25.5 & -- & 729 & 7.1 \\
\hline & $08-21-95$ & USGS & SDDHL & -- & -- & -- & -- & -- & -- & $-\cdot$ \\
\hline \multirow{15}{*}{$\begin{array}{l}442150098174401 \\
(\text { CO-05-90) }\end{array}$} & $10-27-93$ & USGS & SDSU & 1,540 & 7.5 & -- & 10.5 & -- & -- & 0.2 \\
\hline & $11-18-93$ & USGS & SDSU & 1,540 & 7.4 & -- & 10.5 & -- & -. & 0.1 \\
\hline & $12-14-93$ & USGS & SDDHL & -- & -- & -. & -- & -- & -- & -- \\
\hline & $12-14-93$ & USGS & NWQL & 1,540 & 7.1 & -4.5 & 10.0 & 2.4 & 726 & 0.1 \\
\hline & $12-14-93$ & USGS & SDSU & 1,540 & 7.1 & -- & 10.0 & -- & -- & 0.1 \\
\hline & $01-26-94$ & USGS & SDSU & 1,630 & 7.3 & -- & 10.0 & -- & -- & 0.1 \\
\hline & $02-23-94$ & USGS & SDSU & 1,580 & 7.2 & -- & 9.5 & -- & -- & 0.1 \\
\hline & $03-16-94$ & USGS & SDSU & 1,600 & 7.3 & -. & 10.5 & -- & -- & 0.1 \\
\hline & $03-22-94$ & USGS & NWQL & 1,560 & 7.5 & 12.0 & 10.5 & 3.2 & 591 & 0.2 \\
\hline & $03-22-94$ & USGS & SDDHL & -- & -- & -- & -- & -- & -- & -- \\
\hline & 04-06-94 & USGS & SDSU & 1,600 & 7.5 & -- & 10.5 & -- & -- & 0.1 \\
\hline & $05-09-94$ & USGS & SDSU & 1,600 & 7.4 & -- & 11.5 & -- & -- & 0.1 \\
\hline & 05-24-94 & USGS & NWQL & 1,590 & 7.1 & 30.0 & 11.0 & 2.2 & 721 & 0.1 \\
\hline & $05-24-94$ & USGS & SDDHL & -- & -- & -- & -- & -- & -- & .. \\
\hline & 06-28-94 & USGS & NWQL & 1,590 & 7.4 & 21.0 & 11.5 & -- & 720 & 0.1 \\
\hline
\end{tabular}




\begin{tabular}{|c|c|c|c|c|c|c|c|c|c|}
\hline $\begin{array}{l}\text { Dissolved } \\
\text { oxygen, } \\
\text { percent } \\
\text { saturation, } \\
\text { field } \\
(00301)\end{array}$ & $\begin{array}{c}\text { Oxidation- } \\
\text { reduction } \\
\text { potential, } \\
\text { field } \\
(\mathrm{mV}) \\
(00090)\end{array}$ & $\begin{array}{c}\text { Hardness, } \\
\text { total } \\
\text { ( } \mathrm{mg} / \mathrm{L} \\
\left.\text { as } \mathrm{CaCO}_{3}\right) \\
(00900)\end{array}$ & $\begin{array}{l}\text { Alkalinity, } \\
\text { field, } \\
\text { dissolved, IT } \\
\text { (mg/L as } \\
\left.\mathrm{CaCO}_{3}\right) \\
(39086)\end{array}$ & $\begin{array}{c}\text { Coliform, } \\
\text { fecal, } \\
0.7 \\
\mu \mathrm{m}-\mathrm{mf} \\
\text { (cols/ } \\
100 \mathrm{~mL}) \\
(31625)\end{array}$ & $\begin{array}{c}\text { Strep- } \\
\text { tococci } \\
\text { fecal, } \\
\text { KF agar } \\
\text { (cols per } \\
100 \mathrm{~mL} \text { ) } \\
(31673)\end{array}$ & $\begin{array}{l}\text { Calcium, } \\
\text { dissolved } \\
\text { (mg/L } \\
\text { as Ca) } \\
(00915)\end{array}$ & $\begin{array}{l}\text { Magnesium, } \\
\text { dissolved } \\
(\mathrm{mg} / \mathrm{L} \\
\text { as Mg) } \\
(00925)\end{array}$ & $\begin{array}{c}\text { Sodium, } \\
\text { dissolved } \\
\text { (mg/L } \\
\text { as } \mathrm{Na}) \\
(00930)\end{array}$ & $\begin{array}{l}\text { Sodium } \\
\text { percent } \\
\text { (00932) }\end{array}$ \\
\hline 87 & -. & 130 & 91 & K21 & 340 & 30 & 14 & 35 & 33 \\
\hline .- & -- & -- & -- & -- & -- & -- & -- & -- & -- \\
\hline 91 & -- & 280 & 192 & K320 & 130 & 61 & 31 & 72 & 34 \\
\hline -. & -- & -- & -- & -- & -- & -- & -- & -- & -- \\
\hline 87 & -- & 360 & 257 & K40 & -- & 76 & 42 & 90 & 34 \\
\hline -- & -- & -- & -- & -- & -- & -- & -- & -- & -- \\
\hline 78 & -- & 350 & 294 & K32 & K32 & 74 & 41 & 77 & 31 \\
\hline -- & -- & -- & -- & -- & -- & -- & -- & -- & -- \\
\hline 80 & -- & 220 & 115 & 0 & 0 & 78 & 4.9 & 47 & 30 \\
\hline -- & -- & -- & -- & -- & -- & -- & -- & -- & -- \\
\hline 83 & -- & 130 & 78 & 0 & 0 & 29 & 14 & 120 & 64 \\
\hline -- & -- & -- & -- & -- & -. & .. & -- & -- & -- \\
\hline 87 & -- & 190 & 49 & -- & -- & 51 & 16 & 92 & 48 \\
\hline -- & -- & -- & -- & -- & -- & -- & -- & -- & -- \\
\hline 84 & 291 & 160 & 64 & 0 & 0 & 31 & 20 & 80 & 49 \\
\hline -. & -- & -- & -- & -- & -- & -- & -- & -- & -- \\
\hline 79 & -- & 140 & 48 & 0 & 0 & 35 & 13 & 90 & 54 \\
\hline-- & -- & -- & -- & -- & -- & -- & -- & -- & -- \\
\hline 98 & -- & 200 & 62 & K0 & K0 & 42 & 24 & 94 & 48 \\
\hline- & -- & -- & -- & -- & -- & -- & -- & -- & -- \\
\hline -- & 0 & 180 & -- & -- & -- & 40 & 19 & 71 & -- \\
\hline 95 & 232 & 200 & 44 & 0 & 0 & 45 & 20 & 73 & 42 \\
\hline -- & -- & -- & -- & -- & -- & -- & -- & -- & -- \\
\hline 89 & -- & 180 & 58 & 0 & 0 & 43 & 18 & 81 & 47 \\
\hline -- & .- & -- & -- & -- & -- & -- & -- & -- & -- \\
\hline 92 & -- & 140 & 61 & 0 & 0 & 37 & 11 & 73 & 51 \\
\hline -- & -- & -- & -- & -- & -- & -- & -- & -- & -- \\
\hline -- & -- & 150 & 424 & -- & -- & 43 & 11 & 290 & -- \\
\hline -- & -- & 160 & 480 & -- & -- & 44 & 11 & 310 & -- \\
\hline -- & -- & -- & -- & -- & -- & -- & -- & -- & -- \\
\hline 1 & -- & 150 & 469 & 0 & 0 & 45 & 9.6 & 290 & 79 \\
\hline -- & -- & 160 & 463 & -- & -- & 44 & 12 & 310 & -- \\
\hline -- & -- & -- & 480 & -- & -- & -- & 10 & -- & -- \\
\hline -- & -- & 150 & 484 & -- & -- & 39 & 12 & 300 & -- \\
\hline -- & -- & 150 & 486 & -- & -- & 39 & 12 & 300 & -- \\
\hline 2 & -- & 150 & 456 & 0 & 0 & 45 & 9.3 & 280 & 79 \\
\hline-- & -- & -- & -- & -- & -- & -- & -- & -- & -- \\
\hline -- & -- & 140 & 526 & -. & -- & 39 & 11 & 300 & -- \\
\hline -- & -- & 150 & 462 & -- & -- & 44 & 9.9 & 300 & -- \\
\hline 1 & -- & 150 & 490 & -- & -- & 43 & 9.5 & 280 & 79 \\
\hline-- & -- & -- & -- & -- & -- & -- & -- & -- & .- \\
\hline 1 & -- & 150 & 522 & 0 & 0 & 44 & 9.8 & 280 & 79 \\
\hline
\end{tabular}


Table 9. Physical properties and concentrations of inorganic constituents, radioactive nuclides, and total organic carbon obtained from detailed samples-Continued

\begin{tabular}{|c|c|c|c|c|c|c|c|c|c|}
\hline $\begin{array}{l}\text { Station number } \\
\text { (other identifier) }\end{array}$ & Date & $\begin{array}{l}\text { Sodium } \\
\text { adsorp- } \\
\text { tion } \\
\text { ratio } \\
(00931)\end{array}$ & $\begin{array}{l}\text { Potasșium, } \\
\text { dissolved } \\
\text { (mg/L } \\
\text { as K) } \\
(00935)\end{array}$ & $\begin{array}{l}\text { Bicar- } \\
\text { bonate, } \\
\text { field, } \\
\text { dissolved, } \\
\text { IT }(\mathrm{mg} / \\
\left.\text { as } \mathrm{HCO}_{3}\right) \\
(00453)\end{array}$ & $\begin{array}{l}\text { Carbonate, } \\
\text { field, } \\
\text { dissolved, } \\
\text { IT (mg/L } \\
\left.\text { as } \mathrm{CO}_{3}\right) \\
(00452)\end{array}$ & $\begin{array}{l}\text { Sulfate, } \\
\text { dissolved } \\
(\mathrm{mgh} / \\
\left.\text { as } \mathrm{SO}_{4}\right) \\
(00945)\end{array}$ & $\begin{array}{l}\text { Chloride, } \\
\text { dissolved } \\
\text { (mg/L } \\
\text { as Cl) } \\
(00940)\end{array}$ & $\begin{array}{l}\text { Fluoride, } \\
\text { dissolved } \\
\text { (mg/L } \\
\text { as F) } \\
(00950)\end{array}$ & $\begin{array}{c}\text { Silica, } \\
\text { dissolved } \\
\left(\mathrm{mg}^{2} \text { as }\right. \\
\left.\mathrm{SiO}_{2}\right) \\
(00955)\end{array}$ \\
\hline \multirow{6}{*}{$\begin{array}{l}442150098120601 \\
\text { (James River at } \\
\text { Morningside) }\end{array}$} & $05-02-94$ & 2 & 14 & 234 & 0 & 200 & 43 & 0.10 & 6.0 \\
\hline & $05-02-94$ & -- & -- & -- & -- & -- & -- & -- & -- \\
\hline & $05-24-94$ & 2 & 17 & 314 & 0 & 250 & 50 & 0.20 & 7.5 \\
\hline & $05-24-94$ & -- & -- & -- & -- & -- & -- & -- & -- \\
\hline & $06-28-94$ & 2 & 18 & 359 & 0 & 200 & 36 & 0.30 & 13 \\
\hline & $06-28-94$ & -- & -- & -- & -- & -- & -- & -- & -- \\
\hline \multirow{11}{*}{$\begin{array}{l}442150098120602 \\
\text { (Huron Water } \\
\text { Treatment Plant } \\
\text { effluent) }\end{array}$} & $05-02-94$ & 5 & 15 & 76 & 10 & 280 & 46 & 1.0 & 8.8 \\
\hline & $05-02-94$ & -- & -- & -- & -- & -. & -- & -- & -- \\
\hline & $05-24-94$ & 3 & 17 & 47 & 6 & 290 & 56 & 1.4 & 3.6 \\
\hline & $05-24-94$ & -- & -- & -- & -- & -- & -- & -- & -- \\
\hline & $06-28-94$ & 3 & 19 & 68 & 5 & 230 & 43 & 1.3 & 6.7 \\
\hline & $06-28-94$ & -- & -- & -- & -- & -- & -- & -- & -- \\
\hline & $07-26-94$ & 3 & 21 & 46 & 6 & 240 & 51 & 1.4 & 7.3 \\
\hline & $07-26-94$ & -- & -- & -- & -- & -- & -- & -- & -- \\
\hline & $10-26-94$ & 3 & 17 & 69 & 3 & 290 & 50 & 1.3 & 10 \\
\hline & $10-26-94$ & -- & -- & -- & -- & -- & -- & -- & -- \\
\hline & $04-24-95$ & 2 & -- & -- & -- & 290 & 40 & -- & -- \\
\hline \multirow{14}{*}{$\begin{array}{l}442150098174401 \\
(\mathrm{CO}-05-90)\end{array}$} & $11-18-93$ & 11 & -- & 585 & 0 & 310 & 40 & -- & -- \\
\hline & $12-14-93$ & -- & -- & -- & -. & -. & -- & -- & -- \\
\hline & $12-14-93$ & 10 & 9.9 & 572 & 0 & 300 & 35 & 0.40 & 29 \\
\hline & $12-14-93$ & 11 & -- & 565 & 0 & 340 & 38 & -- & -- \\
\hline & $01-26-94$ & -- & -- & 585 & 0 & -. & -- & - & -- \\
\hline & $02-23-94$ & 11 & -- & 590 & 0 & 340 & 39 & -- & -- \\
\hline & $03-16-94$ & 11 & - & 593 & 0 & 360 & 38 & -- & -- \\
\hline & $03-22-94$ & 10 & 10 & 556 & 0 & 300 & 36 & 0.40 & 27 \\
\hline & $03-22-94$ & -- & -- & -- & -- & -. & -- & -- & -- \\
\hline & $04-06-94$ & 11 & -- & 641 & 0 & 290 & 38 & -- & -- \\
\hline & $05-09-94$ & 10 & -- & 564 & 0 & 310 & 38 & -- & -- \\
\hline & $05-24-94$ & 10 & 10 & 597 & 0 & 300 & 37 & 0.40 & 28 \\
\hline & $05-24-94$ & -- & -- & -- & -- & -- & -- & -- & -- \\
\hline & $06-28-94$ & 10 & 10 & 637 & 0 & 300 & 36 & 0.40 & 29 \\
\hline
\end{tabular}




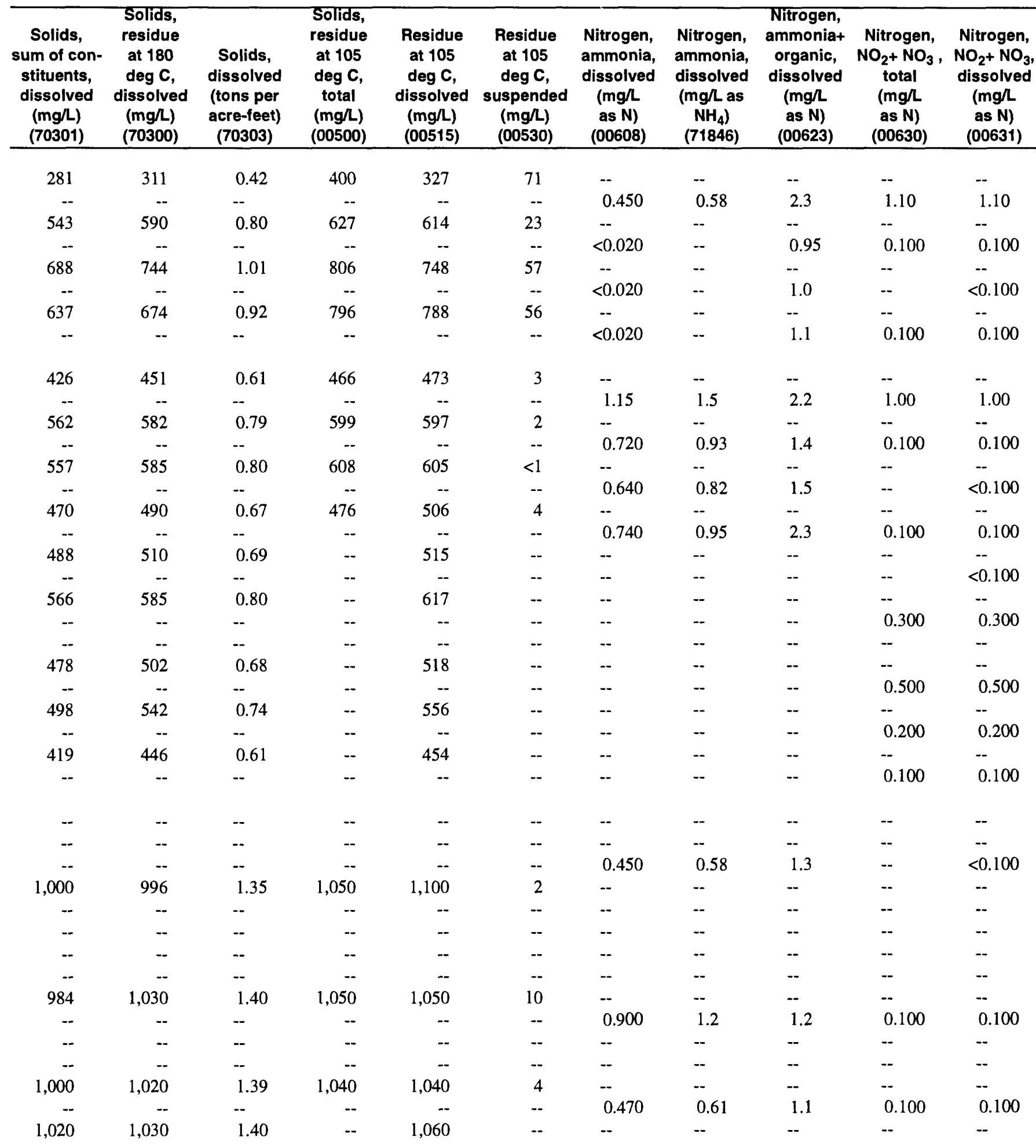


Table 9. Physical properties and concentrations of inorganic constituents, radioactive nuclides, and total organic carbon obtained from detailed samples-Continued

\begin{tabular}{|c|c|c|c|c|c|c|c|c|c|}
\hline $\begin{array}{l}\text { Station number } \\
\text { (other identifier) }\end{array}$ & Date & $\begin{array}{c}\text { Phos- } \\
\text { phorus, } \\
\text { total } \\
\text { (mg/L } \\
\text { as P) } \\
\text { (00665) } \\
\end{array}$ & $\begin{array}{l}\text { Phos- } \\
\text { phorus } \\
\text { ortho, } \\
\text { dissolved } \\
\text { (mg/L } \\
\text { as P) } \\
\text { (00671) } \\
\end{array}$ & $\begin{array}{c}\text { Arsenic, } \\
\text { dissolved } \\
(\mu g / L \\
\text { as As) } \\
(01000)\end{array}$ & $\begin{array}{c}\text { Barium, } \\
\text { dissolved } \\
(\mu \mathrm{g} / \mathrm{L} \\
\text { as } \mathrm{Ba}) \\
(01005) \\
\end{array}$ & $\begin{array}{c}\text { Beryllium, } \\
\text { dissolved } \\
(\mu g / L \\
\text { as } \mathrm{Be}) \\
(01010) \\
\end{array}$ & $\begin{array}{c}\text { Boron, } \\
\text { dissolved } \\
\text { ( } \mu \mathrm{g} / \mathrm{L} \\
\text { as B) } \\
(01020) \\
\end{array}$ & $\begin{array}{l}\text { Cadmium, } \\
\text { dissolved } \\
(\mu g / L \\
\text { as Cd) } \\
(01025) \\
\end{array}$ & $\begin{array}{c}\text { Chromium, } \\
\text { dissolved } \\
(\mu \mathrm{g} / \mathrm{L} \\
\text { as Cr) } \\
(01030) \\
\end{array}$ \\
\hline \multirow{8}{*}{$\begin{array}{l}442150098120601 \\
\text { (James River at } \\
\text { Morningside) }\end{array}$} & $03-22-94$ & -- & -- & 2 & 46 & $<0.5$ & 80 & $<1.0$ & $<5$ \\
\hline & $03-22-94$ & 0.543 & 0.329 & -- & -- & -- & -- & -- & -- \\
\hline & $05-02-94$ & -- & -- & 2 & 61 & $<0.5$ & 130 & $<1.0$ & $<5$ \\
\hline & $05-02-94$ & 0.280 & 0.233 & -- & -- & -- & -- & -- & -- \\
\hline & $05-24-94$ & -- & -- & 4 & 77 & $<0.5$ & 160 & $<1.0$ & $<5$ \\
\hline & $05-24-94$ & 0.360 & 0.314 & -- & -- & -- & -- & -- & -- \\
\hline & $06-28-94$ & -- & -- & 5 & 68 & $<0.5$ & 180 & $<1.0$ & $<5$ \\
\hline & $06-28-94$ & 0.266 & 0.263 & -- & -- & -- & -- & -- & -- \\
\hline \multirow{19}{*}{$\begin{array}{l}442150098120602 \\
\text { (Huron Water } \\
\text { Treatment Plant } \\
\text { effluent) }\end{array}$} & $03-22-94$ & -- & -- & $<1$ & 14 & $<0.5$ & 90 & $<1.0$ & $<5$ \\
\hline & $03-22-94$ & 0.623 & 0.040 & -- & -- & -- & -- & - &.- \\
\hline & $05-02-94$ & -- & -- & $<1$ & 10 & $<0.5$ & 150 & $<1.0$ & $<5$ \\
\hline & $05-02-94$ & 1.36 & 0.041 & -- & -- & -- & -- & -- & -- \\
\hline & $05-24-94$ & -- & -- & $<1$ & 18 & $<0.5$ & 120 & $<1.0$ & $<5$ \\
\hline & $05-24-94$ & 0.743 & 0.063 & -- & -- & -- & -. & -. & -- \\
\hline & $06-28-94$ & -- & -- & 1 & 11 & $<0.5$ & 120 & 1.0 & $<5$ \\
\hline & $06-28-94$ & 0.416 & 0.059 & -- & -- & -- & -- & -- & -- \\
\hline & $07-26-94$ & -- & -. & 1 & 15 & $<0.5$ & 140 & $<1.0$ & $<5$ \\
\hline & $07-26-94$ & .- & -- & -- & -- & -- & -- & $\ldots$ & -- \\
\hline & $10-26-94$ & -- & -- & 1 & 10 & $<0.5$ & 130 & $<1.0$ & $<5$ \\
\hline & $10-26-94$ & -- & -- & -- & -- & -- & -- & -- & -- \\
\hline & $04-24-95$ & -- & -- & -- & -- & -- & -- & -- & -- \\
\hline & $04-24-95$ & -- & -- & $<1$ & 11 & $<0.5$ & 100 & $<1.0$ & $<5$ \\
\hline & $04-24-95$ & -- & -- & -- & -. & -- & -- & -- & -- \\
\hline & $07-06-95$ & .- & .- & $<1$ & 14 & $<0.5$ & 100 & $<1.0$ & $<5$ \\
\hline & $07-06-95$ & -- & -- & -- & -- & -- & -- & -- & -- \\
\hline & $08-21-95$ & -- & -- & 1 & 12 & $<0.5$ & 60 & $<1.0$ & $<5$ \\
\hline & $08-21-95$ & -- & -- & - & -- & -- & -- & -- & -- \\
\hline \multirow{15}{*}{$\begin{array}{l}442150098174401 \\
(\mathrm{CO}-05-90)\end{array}$} & $10-27-93$ & -- & -- & -- & -- & -- & -- & -- & -- \\
\hline & $11-18-93$ & -- & -- & -- & -- & -- & -- & -- & -- \\
\hline & $12-14-93$ & 0.123 & 0.031 & -- & -- & -- & -- & -- & -. \\
\hline & $12-14-93$ & -- & -- & 1 & 19 & $<0.5$ & 340 & $<1.0$ & $<5$ \\
\hline & $12-14-93$ & -- & -- & -- & -- & - & -- & -- & -- \\
\hline & $01-26-94$ & -- & -- & -- & -- & -- & -- & -- & -- \\
\hline & $02-23-94$ & -- & -- & -- & -- & -- & -- & -- & -- \\
\hline & $03-16-94$ & -- & -- & -- & -- & -- & -- & -- & -- \\
\hline & $03-22-94$ & -- & -- & 1 & 18 & $<0.5$ & 340 & $<1.0$ & $<5$ \\
\hline & $03-22-94$ & 0.133 & 0.025 & -- & -- & -- & -- & -- & -- \\
\hline & $04-06-94$ & -- & -- & -- & -- & -- & -- & -- & -- \\
\hline & 05-09-94 & -- & -- & -- & -- & -- & -- & -- & -- \\
\hline & $05-24-94$ & -- & -- & 1 & 19 & $<0.5$ & 320 & $<1.0$ & $<5$ \\
\hline & $05-24-94$ & -- & 0.014 & -- & -- & -- & -- & -- & -. \\
\hline & $06-28-94$ & -- & -- & 1 & 20 & $<0.5$ & 340 & 1.0 & $<5$ \\
\hline
\end{tabular}




\begin{tabular}{|c|c|c|c|c|c|c|c|c|c|c|}
\hline $\begin{array}{c}\text { Cobalt, } \\
\text { dissolved } \\
(\mu g / L \\
\text { as Co) } \\
(01035) \\
\end{array}$ & $\begin{array}{l}\text { Copper, } \\
\text { dissolved } \\
(\mu g / L \text { as Cu }) \\
(01040) \\
\end{array}$ & $\begin{array}{c}\text { Iron, } \\
\text { dissolved } \\
(\mu \mathrm{g} / \mathrm{L} \\
\text { as Fe) } \\
(01046) \\
\end{array}$ & $\begin{array}{c}\text { Lead, } \\
\text { dissolved } \\
(\mu \mathrm{g} / \mathrm{L} \\
\mathrm{as} \mathrm{Pb}) \\
(01049) \\
\end{array}$ & $\begin{array}{c}\text { Lithium, } \\
\text { dissolved } \\
(\mu g / \mathrm{L} \\
\text { as Li) } \\
(01130) \\
\end{array}$ & $\begin{array}{c}\text { Manga- } \\
\text { nese, } \\
\text { dissolved } \\
(\mu g / \mathrm{L} \\
\text { as Mn) } \\
(01056) \\
\end{array}$ & $\begin{array}{c}\text { Mercury, } \\
\text { dissolved } \\
(\mu \mathrm{g} / \mathrm{L} \\
\text { as } \mathrm{Hg}) \\
(71890) \\
\end{array}$ & $\begin{array}{c}\text { Molyb- } \\
\text { denum, } \\
\text { dissolved } \\
(\mu g / \mathrm{l} \\
\text { as Mo) } \\
(01060) \\
\end{array}$ & $\begin{array}{c}\text { Nickel, } \\
\text { dissolved } \\
(\mu \mathrm{g} / \mathrm{L} \\
\text { as Ni) } \\
(01065) \\
\end{array}$ & $\begin{array}{c}\text { Selenium, } \\
\text { dissolved } \\
(\mu \mathrm{g} / \mathrm{L} \\
\text { as Se) } \\
(01145) \\
\end{array}$ & $\begin{array}{c}\text { Silver, } \\
\text { dissolved } \\
(\mu \mathrm{g} / \\
\text { as Ag) } \\
(01075) \\
\end{array}$ \\
\hline 4 & $<10$ & 240 & $<10$ & 19 & 340 & $<0.1$ & 10 & $<10$ & $<1$ & $<1.0$ \\
\hline -. & -- & -- & -. & -- & -- & -- & -- & -- & -- & -- \\
\hline$<3$ & $<10$ & 22 & $<10$ & 41 & 120 & $<0.1$ & $<10$ & $<10$ & $<1$ & $<1.0$ \\
\hline -- & -- & -- & -- & -- & -- & -- & -. & -- & -- & -- \\
\hline$<3$ & $<10$ & 6 & $<10$ & 53 & 91 & 0.1 & $<10$ & $<10$ & $<1$ & $<1.0$ \\
\hline -- & -- & -- & -- & -- & -- & -- & -- & -. & -- & -- \\
\hline$<3$ & $<10$ & 11 & 10 & 53 & 170 & $<0.1$ & $<10$ & $<10$ & $<1$ & $<1.0$ \\
\hline -- & -- & -- & -- & -- & -- & -- & -- & -- & -- & -- \\
\hline$<3$ & $<10$ & 6 & $<10$ & 28 & 3 & $<0.1$ & $<10$ & $<10$ & $<1$ & $<1.0$ \\
\hline -- & -- & -- & -. & -- & -- & -- & -- & -- & -- & -- \\
\hline$<3$ & $<10$ & 7 & $<10$ & 54 & 3 & $<0.1$ & $<10$ & $<10$ & $<1$ & $<1.0$ \\
\hline -- & -- & -- & -- & -- & .- & -- & -- & -- & -- & -- \\
\hline$<3$ & $<10$ & 7 & $<10$ & 53 & 2 & $<0.1$ & $<10$ & $<10$ & $<1$ & $<1.0$ \\
\hline-- & -- & -- & -- & $\ldots$ & -- & -- & -- & -- & -- & -- \\
\hline$<3$ & $<10$ & 5 & 10 & 53 & 2 & $<0.1$ & $<10$ & $<10$ & $<1$ & 3.0 \\
\hline -- & -- & -- & -- & -. & -- & -. & -- & -- & -. & -. \\
\hline$<3$ & $<10$ & 55 & $<10$ & 49 & 3 & $<0.1$ & 10 & $<10$ & -- & $<1.0$ \\
\hline -- & -- & -- & -- & -- & -- & -- & -- & -- & -- & -- \\
\hline$<3$ & $<10$ & 5 & $<10$ & 67 & 2 & $<0.1$ & $<10$ & $<10$ & -- & $<1.0$ \\
\hline -- & -- & -- & -- & -- & -- & -- & -- & -- & -- & -- \\
\hline -- & -- & 0 & -- & -. & 0 & -- & -- & -- & -- & -- \\
\hline$<3$ & $<10$ & 4 & $<10$ & 43 & $<1$ & $<0.1$ & $<10$ & 10 & -- & $<1.0$ \\
\hline -- & -- & -- & -- & -- & -- & .- & - & -. & -- & -- \\
\hline$<3$ & $<10$ & 7 & $<10$ & 54 & 4 & $<0.1$ & $<10$ & $<10$ & -- & $<1.0$ \\
\hline- & -- & - & -- & -- & -- & -- & -- & -- & -- & -- \\
\hline$<3$ & $<10$ & 6 & $<10$ & 46 & 1 & $<0.1$ & $<10$ & $<10$ & -- & $<1.0$ \\
\hline -- & -- & -- & -- & -- & -- & -- & -- & -- & -- & - \\
\hline-- & -. & 1,200 & -- & -- & 420 & -- & -. & -- & -- & -- \\
\hline-- & -- & 1,200 & -- & -- & 460 & -- & -- & -- & -. & -- \\
\hline -- & -- & -- & -- & -- & -- & -- & -- & -- & -- & -. \\
\hline$<3$ & $<10$ & 1,100 & $<10$ & 85 & 410 & $<0.1$ & $<10$ & $<10$ & $<1$ & $<1.0$ \\
\hline- & -- & 1,200 & -- & -- & 440 & -- & - & -- & -- & - \\
\hline-- & -. & -- & -- & -- & -. & -- & -. & -- & -- & -- \\
\hline -- & -- & 1,200 & -- & -- & 470 & -- & -- & -- & -. & -- \\
\hline- & -- & 1,200 & -- & -- & 460 & -- & -- & -- & -- & -- \\
\hline$<3$ & $<10$ & 1,200 & $<10$ & 81 & 400 & $<0.1$ & 20 & $<10$ & $<1$ & $<1.0$ \\
\hline -- & -- & -- & -- & -- & -- & -- & -- & -- & -- & -- \\
\hline -- & -- & 1,200 & -- & -- & 460 & -- & .- & -- & -- & -. \\
\hline -. & -- & 1,200 & -- & -- & 430 & -- & - & -- & -- & -- \\
\hline$<3$ & $<10$ & 1,100 & 10 & 84 & 390 & $<0.1$ & $<10$ & 10 & $<1$ & 3.0 \\
\hline -- & -- & -- & -- & -- & -- & -- & -- & -- & -- & -- \\
\hline$<3$ & $<10$ & 1,100 & $<10$ & 84 & 400 & $<0.1$ & $<10$ & $<10$ & $<1$ & $<1.0$ \\
\hline
\end{tabular}


Table 9. Physical properties and concentrations of inorganic constituents, radioactive nuclides, and total organic carbon obtained from detailed samples-Continued

\begin{tabular}{|c|c|c|c|c|c|c|c|c|c|}
\hline $\begin{array}{l}\text { Station number } \\
\text { (other identifier) }\end{array}$ & Date & $\begin{array}{c}\text { Strontium, } \\
\text { dissolved } \\
(\mu g / L \\
\text { as } \mathrm{Sr}) \\
(01080) \\
\end{array}$ & $\begin{array}{c}\text { Vanadium, } \\
\text { dissolved } \\
(\mu \mathrm{g} / \mathrm{L} \\
\text { as V) } \\
(01085) \\
\end{array}$ & $\begin{array}{c}\text { Zinc, } \\
\text { dissolved } \\
(\mu g / L \\
\text { as } \mathrm{Zn}) \\
(01090) \\
\end{array}$ & $\begin{array}{c}\text { Gross } \\
\text { alpha, } \\
\text { dissolved } \\
\text { ( } \mu \mathrm{g} / \mathrm{L} \text { as } \\
\text { natural } \\
\text { uranium) } \\
(\mathbf{8 0 0 3 0 )} \\
\end{array}$ & $\begin{array}{c}\text { Alpha, } \\
\text { count, } \\
2 \text { sigma, } \\
\text { dissolved } \\
\text { as natural } \\
\text { uranium } \\
(\mu \mathrm{g} / \mathrm{L}) \\
(75986) \\
\end{array}$ & $\begin{array}{c}\text { Alpha } \\
\text { radio, } \\
\text { dissolved } \\
\text { as } \\
\text { Th-230 } \\
(\mathrm{pci} / \mathrm{L}) \\
(04126) \\
\end{array}$ & $\begin{array}{c}\text { Alpha } \\
\text { count, } \\
2 \text { sigma, } \\
\text { dissolved } \\
\text { as } \\
\text { Th-230 } \\
\text { (pci/L) } \\
(75987) \\
\end{array}$ & $\begin{array}{c}\text { Gross } \\
\text { alpha, } \\
\text { dissolved } \\
\text { (pci/L as } \\
\text { U-natural) } \\
\text { (01515) }\end{array}$ \\
\hline \multirow{8}{*}{$\begin{array}{l}442150098120601 \\
\text { (James River at } \\
\text { Morningside) }\end{array}$} & $03-22-94$ & 160 & $<6$ & 17 & 0.6 & 1.5 & $<0.6$ & 1.1 & -- \\
\hline & $03-22-94$ & -- & -- & -- & -- & -- & -- & -- & 1.2 \\
\hline & $05-02-94$ & 310 & $<6$ & 17 & 2.5 & 3.5 & 1.6 & 2.2 & -- \\
\hline & $05-02-94$ & -- & -- & -- & -- & -- & - & -- & 2.7 \\
\hline & $05-24-94$ & 420 & $<6$ & 17 & 1.1 & 3.4 & 0.8 & 2.4 & -- \\
\hline & $05-24-94$ & -- & -- & -- & -- & -- & -- & -- & 2.7 \\
\hline & $06-28-94$ & 390 & $<6$ & $<3$ & 3.1 & 3.4 & 2.3 & 2.5 & -- \\
\hline & $06-28-94$ & -- & -- & -- & -- & -- & -- & -- & 3.1 \\
\hline \multirow{19}{*}{$\begin{array}{l}442150098120602 \\
\text { (Huron Water } \\
\text { Treatment Plant } \\
\text { effluent) }\end{array}$} & $03-22-94$ & 200 & $<6$ & 6 & 1.0 & 1.8 & 0.7 & 1.4 & -- \\
\hline & $03-22-94$ & -- & -- & -- & -- & -- & -- & -- & 1.8 \\
\hline & $05-02-94$ & 150 & $<6$ & 18 & $<0.6$ & 2.3 & $<0.6$ & 1.6 & -- \\
\hline & $05-02-94$ & -- & -- & -- & -- & -- & -- & -- & 1.1 \\
\hline & $05-24-94$ & 260 & $<6$ & 17 & 0.8 & 2.3 & $<0.6$ & 1.5 & -- \\
\hline & $05-24-94$ & -- & -- & -- & -- & -- & -- & -- & 0.8 \\
\hline & $06-28-94$ & 160 & $<6$ & 20 & 1.5 & 2.4 & 1.1 & 1.7 & -- \\
\hline & $06-28-94$ & -- & -- & -- & -- & -- & -- & -- & 1.3 \\
\hline & $07-26-94$ & 190 & $<6$ & 20 & -- & -- & -- & -- & -- \\
\hline & $07-26-94$ & -- & -- & -- & -- & -- & -- & -- & -- \\
\hline & $10-26-94$ & 190 & $<6$ & 28 & -- & -- & -- & -- & -- \\
\hline & $10-26-94$ & -- & -- & -- & -- & -- & -- & -- & -- \\
\hline & $04-24-95$ & -- & - & -- & -- & -- & -- & -- & -- \\
\hline & $04-24-95$ & 210 & $<6$ & 24 & -- & -- & -- & -- & -- \\
\hline & $04-24-95$ & -- & -- & -- & -- & -- & -- & -- & -- \\
\hline & $07-06-95$ & 190 & $<6$ & 23 & -- & -- & -- & -- & -- \\
\hline & $07-06-95$ & -- & -- & -- & -- & -- & -- & -- & -- \\
\hline & $08-21-95$ & 160 & $<6$ & 20 & -. & -- & -- & -- & -- \\
\hline & $08-21-95$ & -- & - & -- & -- & -- & - & -- & -- \\
\hline \multirow{15}{*}{$\begin{array}{l}442150098174401 \\
(\mathrm{CO}-05-90)\end{array}$} & $10-27-93$ & -- & -- & -- & -- & -- & -- & -- & -- \\
\hline & $11-18-93$ & -- & -- & -- & -- & -- & -- & -- & -- \\
\hline & $12-14-93$ & -- & -- & -. & -- & -- & - & -- & 3.1 \\
\hline & $12-14-93$ & 420 & $<6$ & $<3$ & 3.6 & 4.8 & 2.6 & 3.5 & -- \\
\hline & $12-14-93$ & -- & -- & -- & -- & -- & -- & -- & -- \\
\hline & $01-26-94$ & -- & -- & -- & -- & -- & -- & -- & -- \\
\hline & $02-23-94$ & -- & -- & -- & -- & -- & -- & -- & -- \\
\hline & $03-16-94$ & -- & -- & -- & -- & -- & -- & -- & -- \\
\hline & $03-22-94$ & 430 & $<6$ & $<3$ & 2.6 & 6.2 & 1.9 & 4.4 & -- \\
\hline & $03-22-94$ & -- & -- & -- & -- & -- & -- & -- & 1.8 \\
\hline & 04-06-94 & -- & -- & -- & -- & -- & -- & -- & -- \\
\hline & 05-09-94 & -- & -- & -- & - & -- & -- & -- & -- \\
\hline & $05-24-94$ & 420 & $<6$ & $<3$ & 1.5 & 6.1 & 1.0 & 4.4 & -- \\
\hline & $05-24-94$ & -- & -- & -- & -- & -- & -- & -- & 1.5 \\
\hline & $06-28-94$ & 420 & $<6$ & 3 & 1.2 & 4.5 & 0.9 & 3.4 & -- \\
\hline
\end{tabular}




\begin{tabular}{|c|c|c|c|c|c|c|c|c|c|c|}
\hline $\begin{array}{c}\text { Alpha } \\
\text { dissolved, } \\
\text { counting } \\
\text { error } \\
\text { (pci/L) } \\
(01504) \\
\end{array}$ & $\begin{array}{c}\text { Gross } \\
\text { beta, } \\
\text { dissolved } \\
\text { (pcil as } \\
\text { Cs-137) } \\
(03515) \\
\end{array}$ & $\begin{array}{c}\text { Beta, } 2 \\
\text { sigma, } \\
\text { dissolved } \\
\text { as Cs-137 } \\
\text { (pci/ }) \\
(75989) \\
\end{array}$ & $\begin{array}{c}\text { Gross } \\
\text { beta, } \\
\text { dissolved } \\
\text { (pci/l as } \\
\mathrm{Sr} / \mathrm{Yt}-90) \\
(80050) \\
\end{array}$ & $\begin{array}{c}\text { Beta, } 2 \\
\text { sigma, } \\
\text { dissolved } \\
\text { as Sr90/Y90 } \\
(\mathrm{pci} / \mathrm{L}) \\
(75988) \\
\end{array}$ & $\begin{array}{c}\text { Gross } \\
\text { beta, } \\
\text { counting } \\
\text { error } \\
\text { (pcil as } \\
\text { Sr90) } \\
(03528) \\
\end{array}$ & $\begin{array}{c}\text { Radium } \\
226, \\
\text { dissolved, } \\
\text { radon } \\
\text { method } \\
\text { (pcil) } \\
(09511) \\
\end{array}$ & $\begin{array}{c}\text { Radium } \\
\text { 226, } \\
\text { dissolved, } \\
\text { counting } \\
\text { error } \\
\text { (pci/) } \\
\text { (09504) } \\
\end{array}$ & $\begin{array}{c}\text { Radium } \\
228, \\
\text { dissolved } \\
\text { (pci/l as } \\
\text { Ra-228) } \\
(81366) \\
\end{array}$ & $\begin{array}{c}\text { Radium } \\
\text { 228, } \\
\text { dissolved, } \\
\text { counting } \\
\text { error } \\
\text { (pci/L) } \\
(81367) \\
\end{array}$ & $\begin{array}{c}\text { Carbon, } \\
\text { organic, } \\
\text { total } \\
(\mathrm{mg} / \mathrm{h} \\
\text { as C) } \\
(00680) \\
\end{array}$ \\
\hline -- & 23 & 3.2 & 17 & 2.4 & -- & -- & -- & -- & -- & 18 \\
\hline-- & -- & -- & 19 & -. & 2.9 & 0.10 & 0.1 & 1.0 & 0.40 & -- \\
\hline -. & 23 & 3.7 & 17 & 2.7 & -- & -- & -- & -- & -- & 14 \\
\hline -- & -- & -- & 14 & -- & 4.3 & 0.20 & 0.1 & 1.3 & 0.40 & -- \\
\hline- & 24 & 4.1 & -- & 3.1 & -- & -- & -- & -- & -- & 16 \\
\hline -- & -- & -- & 46 & -- & 13.7 & 0.10 & 0.1 & 0.80 & 0.20 & -- \\
\hline -. & 27 & 4.4 & 20 & 3.3 & -- & -- & -- & -- & -- & 17 \\
\hline -- & -. & -- & 19 & -- & 6.7 & 0.40 & 0.2 & 1.2 & 0.40 & -- \\
\hline -. & 23 & 3.3 & 19 & 2.5 & -. & -- & - & -- & -- & 5.6 \\
\hline .. & -- & -- & 19 & -- & 3.7 & $<0.10$ & 0.1 & 1.3 & 0.40 & -- \\
\hline -. & 21 & 3.4 & 15 & 2.5 & -. & -- & -- & -- & -- & 5.3 \\
\hline-- & -- & -- & 18 & -- & 4.1 & 0.20 & 0.1 & 0.70 & 0.20 & -- \\
\hline -. & 23 & 3.5 & -- & 2.7 & -- & -- & -- & -- & -- & 6.6 \\
\hline- & -- & -. & 18 & -- & 4.4 & 0.10 & 0.1 & 0.80 & 0.30 & -. \\
\hline -- & 25 & 3.6 & 19 & 2.7 & -- & - & -- & -- & -- & 8.2 \\
\hline -- & -- & -- & 27 & -- & 4.3 & 0.10 & 0.2 & 1.9 & 0.60 & -- \\
\hline - & -- & -- & -- & -- & -- & -- & -- & -- & -- & .. \\
\hline -- & -- & -- & -- & -- & - & - & -. & -- & -- & -. \\
\hline- & -- & -- & -- & -- & -- & -. & -- & -- & -- & -- \\
\hline-- & -- & -- & -- & -- & -- & -- & -- & -- & -- & -- \\
\hline-- & -- & -- & -- & -- & -- & -. & -- & -- & -- & -- \\
\hline- & -- & -- & -- & - & - & -. & -- & -- & -- & -. \\
\hline -- & -- & -- & -- & -- & -- & -. & -- & -- & -. & -. \\
\hline-- & -- & -- & -- & -- & -- & -- & -- & -- & -- & -- \\
\hline -. & -. & -- & -- & -- & -- & -- & -- & -- & -- & -- \\
\hline-- & -- & -- & -- & -- & -. & -- & -. & -- & -- & -- \\
\hline-- & -- & -- & -- & -- & -- & -- & -- & -. & -- & -- \\
\hline-- & -- & -- & -- & -. & -- & -- & -- & -- & -- & -- \\
\hline -- & -- & -- & -- & -- & -- & .- & -- & -- & -- & -- \\
\hline 3.5 & -- & -- & 35 & -- & 9.2 & 0.50 & 0.3 & 1.2 & 0.30 & -- \\
\hline -- & 14 & 3.5 & 10 & 2.6 & -- & -- & -- & -- & -- & 6.0 \\
\hline -- & -- & -- & -. & -- & -. & -- & -- & -- & -- & -- \\
\hline-- & -- & -- & -- & -- & -- & -- & -- & -- & -- & -- \\
\hline -- & -- & -- & -- & -- & -- & -. & -- & -- & -- & -- \\
\hline-- & -- & -- & -- & -- & -- & -. & -- & -- & - & -- \\
\hline-- & 13 & 3.3 & 9.8 & 2.5 & -- & -- & -- & -- & -- & 7.0 \\
\hline -- & -- & -- & 15 & -- & 7.7 & $<0.10$ & 0.1 & 1.1 & 0.30 & -- \\
\hline-- & -- & -- & -- & -- & -- & -- & -- & -- & -- & -- \\
\hline -- & -- & -- & -- & -- & -. & -- & -- & -- & -- & -- \\
\hline -- & 12 & 3.3 & 8.9 & 2.4 & -- & -- & -- & -- & -- & 6.8 \\
\hline-- & -- & -- & 20 & -- & 7.8 & 0.30 & 0.3 & 1.0 & 0.30 & -- \\
\hline -- & 12 & 3.2 & 9.1 & 2.4 & -. & -- & -- & -- & -- & 8.0 \\
\hline
\end{tabular}


Table 9. Physical properties and concentrations of inorganic constituents, radioactive nuclides, and total organic carbon obtained from detailed samples-Continued

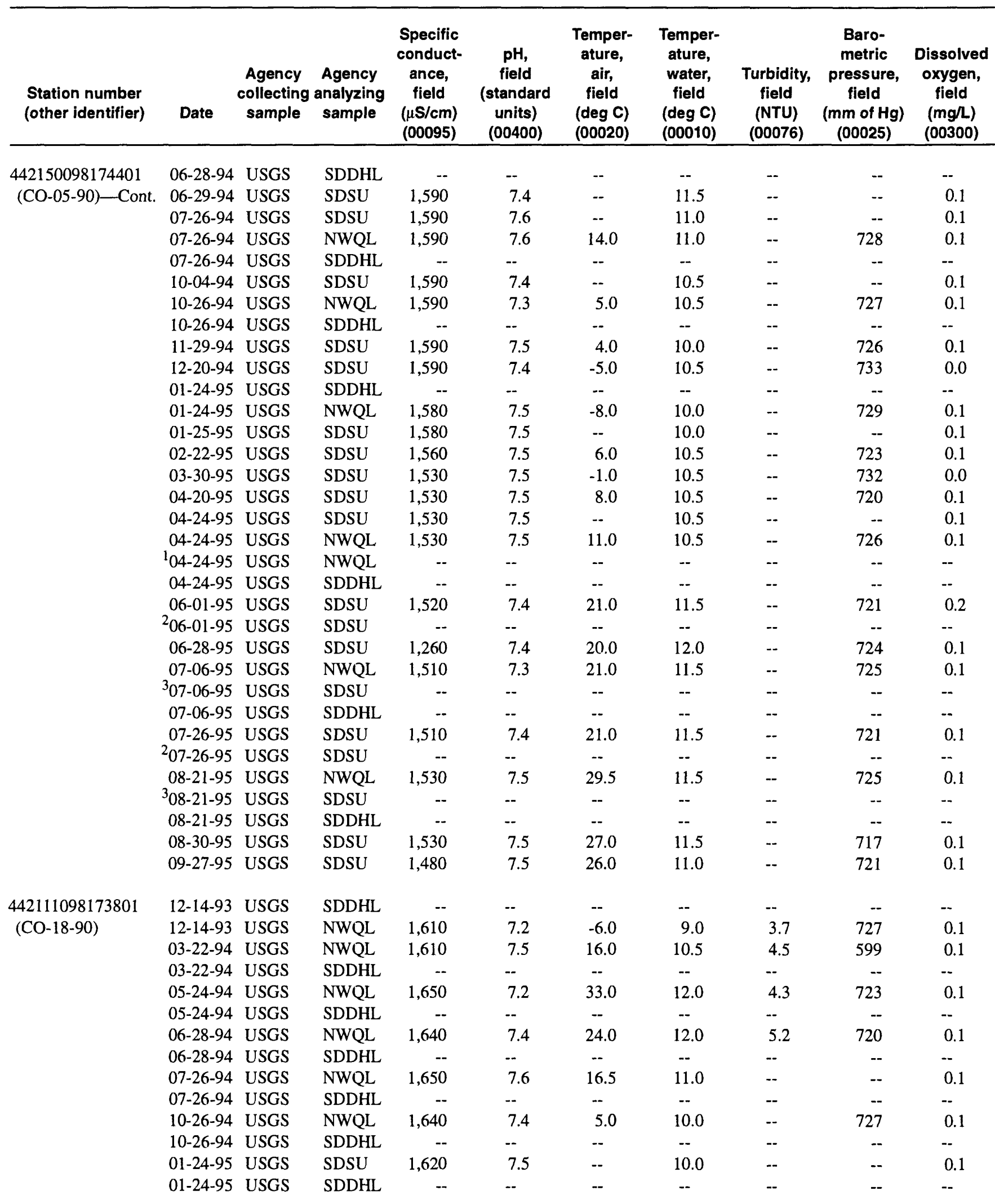




\begin{tabular}{|c|c|c|c|c|c|c|c|c|c|}
\hline $\begin{array}{l}\text { Dissolved } \\
\text { oxygen, } \\
\text { percent } \\
\text { saturation, } \\
\text { field } \\
(00301)\end{array}$ & $\begin{array}{l}\text { Oxidation- } \\
\text { reduction } \\
\text { potential, } \\
\text { field } \\
(\mathrm{mV}) \\
(00090)\end{array}$ & $\begin{array}{l}\text { Hardness, } \\
\text { total } \\
(\mathrm{mg} / \mathrm{L} \\
\left.\text { as } \mathrm{CaCO}_{3}\right) \\
(00900)\end{array}$ & $\begin{array}{l}\text { Alkalinity, } \\
\text { field, } \\
\text { dissolved, IT } \\
\left(\mathrm{mg}^{\prime} \mathrm{L} \text { as }\right. \\
\left.\mathrm{CaCO}_{3}\right) \\
(39086) \\
\end{array}$ & $\begin{array}{c}\text { Collform, } \\
\text { fecal, } \\
0.7 \\
\mu \mathrm{m}-\mathrm{mf} \\
\text { (cols/ } \\
100 \mathrm{~mL}) \\
(31625) \\
\end{array}$ & $\begin{array}{c}\text { Strep- } \\
\text { tococci } \\
\text { fecal, } \\
\text { KF agar } \\
\text { (cols per } \\
100 \mathrm{~mL} \text { ) } \\
(31673) \\
\end{array}$ & $\begin{array}{c}\text { Calcium, } \\
\text { dissolved } \\
\text { (mg/h } \\
\text { as Ca) } \\
(00915) \\
\end{array}$ & $\begin{array}{c}\text { Magnesium, } \\
\text { dissolved } \\
\text { (mg/L } \\
\text { as Mg) } \\
(00925) \\
\end{array}$ & $\begin{array}{c}\text { Sodium, } \\
\text { dissolved } \\
\text { (mg/h } \\
\text { as Na) } \\
(00930) \\
\end{array}$ & $\begin{array}{l}\text { Sodium } \\
\text { percent } \\
(00932) \\
\end{array}$ \\
\hline -- & -. & -- & -- & -- & -- & -- & -- & -- & -- \\
\hline -- & -- & 140 & 496 & -- & -- & 40 & 11 & 300 & -- \\
\hline -- & -153 & 150 & 485 & -. & -- & 43 & 10 & 290 & -- \\
\hline 1 & -153 & 150 & 485 & 0 & 0 & 44 & 9.5 & 290 & 80 \\
\hline -- & -- & .. & -- & -- & -- & -- & -- & -. & -. \\
\hline -. & .- & 150 & 438 & .- & -- & 44 & 9.5 & 290 & - \\
\hline 1 & -86 & 160 & 444 & K0 & K0 & 47 & 10 & 290 & 79 \\
\hline -- & -- & -- & -- & -- & -- & -- & -- & -- & -- \\
\hline 1 & -- & 150 & 470 & -- & -- & 42 & 10 & 300 & -- \\
\hline 0 & -- & 150 & 492 & -- & -- & 44 & 10 & 300 & -- \\
\hline -- & -- & -- & -- & -- & -. & -- & - & -- & .. \\
\hline 1 & -117 & 150 & 465 & 0 & 0 & 43 & 9.6 & 290 & 80 \\
\hline -- & -117 & 150 & 465 & -- & -- & 45 & 10 & 300 & -- \\
\hline 1 & -133 & 150 & 472 & -- & -- & 43 & 10 & 300 & -- \\
\hline 0 & .126 & 150 & 440 & -- & -- & 43 & 10 & 300 & -- \\
\hline 1 & -124 & 150 & 462 & -- & -- & 43 & 9.6 & 290 & -- \\
\hline -- & -82 & 150 & 468 & -. & -- & 42 & 9.7 & 300 & -- \\
\hline 1 & -82 & 160 & 468 & 0 & 0 & 48 & 10 & 300 & 79 \\
\hline -- & -- & 160 & -- & -- & -- & 47 & 10 & 300 & 79 \\
\hline -- & -- & -- & -. & -- & -- & -- & -- & -- & -- \\
\hline 2 & -- & 150 & 534 & -- & -. & 43 & 10 & 300 & -- \\
\hline -- & -- & 150 & -- & -- & -- & 44 & 10 & 300 & -- \\
\hline 1 & -- & 150 & 408 & -. & -- & 44 & 10 & 300 & -- \\
\hline 1 & -- & 160 & 449 & 0 & 0 & 46 & 9.8 & 270 & 78 \\
\hline -- & -- & 150 & -- & .. & -- & 44 & 10 & 300 & - \\
\hline -- & -- & -- & -- & -- & -- & -. & - & -- & -- \\
\hline 1 & -116 & 150 & 452 & -- & -- & 42 & 10 & 300 & -- \\
\hline -- & -- & 150 & -- & -- & -- & 42 & 10 & 300 & -- \\
\hline 1 & -120 & 150 & 455 & 0 & 0 & 44 & 9.5 & 280 & 79 \\
\hline -- & -- & 150 & -- & -- & -- & 43 & 11 & 300 & -- \\
\hline -- & -- & -- & -- & -- & -- & -- & - & -- & -- \\
\hline 1 & -108 & 150 & 474 & -- & -- & 42 & 10 & 290 & -- \\
\hline 1 & -111 & 150 & 460 & -- & -- & 42 & 11 & 310 & -- \\
\hline -- & -- & -- & -- & -- & -- & -- & -- & -- & -- \\
\hline 1 & -- & 170 & 529 & 0 & 0 & 48 & 12 & 300 & 78 \\
\hline 1 & -- & 170 & 403 & 0 & 0 & 48 & 11 & 280 & 77 \\
\hline -- & -- & -- & -- & -- & -- & -- & -- & -- & -- \\
\hline 1 & .. & 160 & 478 & -- & -- & 46 & 12 & 280 & 77 \\
\hline -- & -- & -- & -- & -- & -- & -. & -- & -- & -- \\
\hline 1 & -121 & 170 & 534 & 0 & 0 & 47 & 12 & 290 & 78 \\
\hline -- & -- & .. & -- & -- & -- & -- & -- & -- & -- \\
\hline 1 & -134 & 170 & 498 & 0 & 0 & 47 & 12 & 290 & 78 \\
\hline -- & -- & -- & -- & -- & -- & -- & -- & -- & - \\
\hline 1 & -117 & 170 & 454 & K0 & K0 & 50 & 12 & 300 & 78 \\
\hline -- & -- & -- & -- & -- & -- & -- & -- & -- & -- \\
\hline 1 & -- & 160 & 460 & -- & -- & 42 & 13 & 310 & -- \\
\hline -- & -- & -- & -- & -- & -- & -- & -- & -- & -- \\
\hline
\end{tabular}


Table 9. Physical properties and concentrations of inorganic constituents, radioactive nuclides, and total organic carbon obtained from detailed samples-Continued

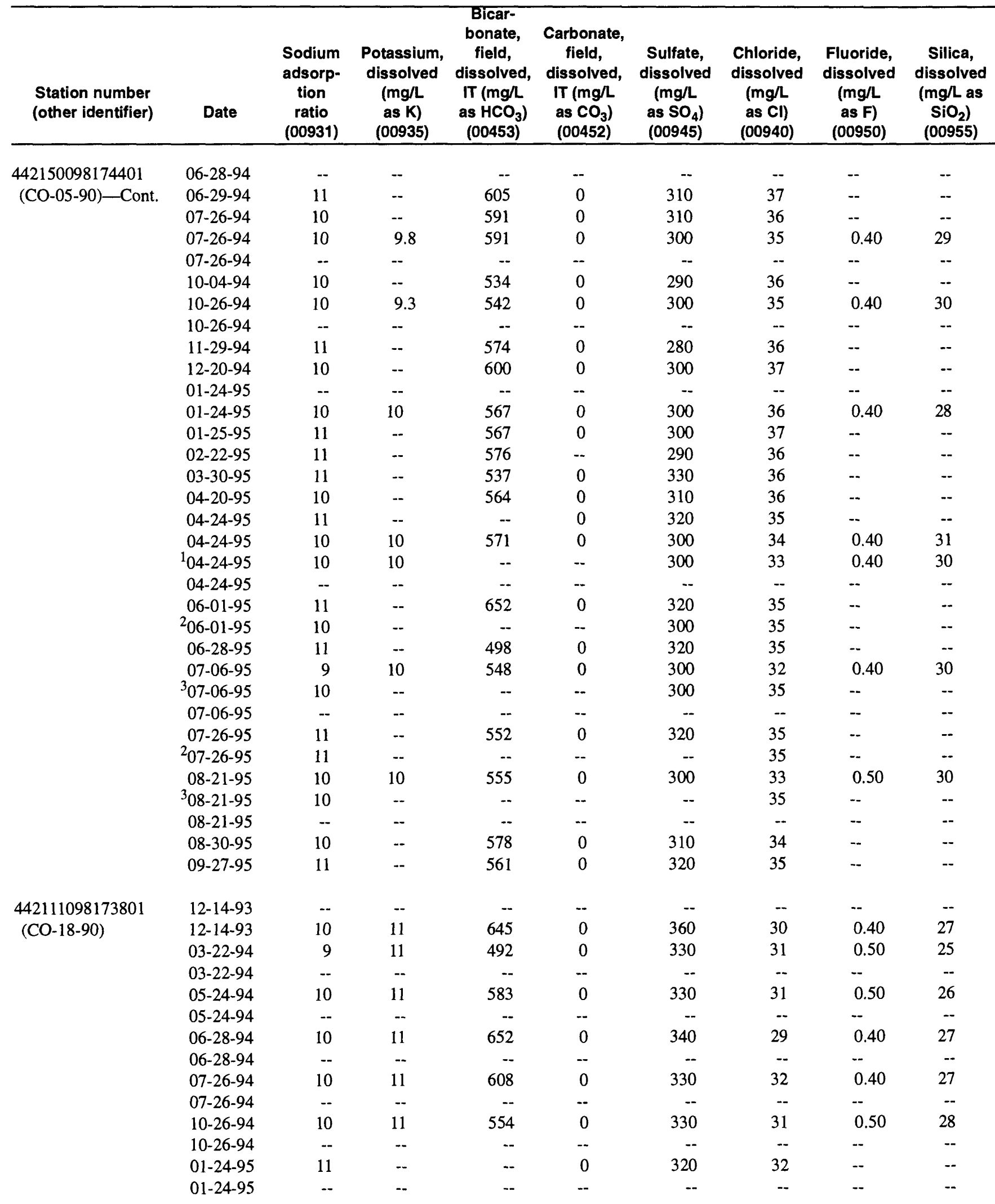




\begin{tabular}{|c|c|c|c|c|c|c|c|c|c|c|}
\hline $\begin{array}{l}\text { Solids, } \\
\text { sum of con- } \\
\text { stituents, } \\
\text { dissolved } \\
\text { (mg/L) } \\
(70301) \\
\end{array}$ & $\begin{array}{c}\text { Solids, } \\
\text { residue } \\
\text { at } 180 \\
\text { deg C, } \\
\text { dissolved } \\
(\mathrm{mg} / \mathrm{L}) \\
(70300) \\
\end{array}$ & $\begin{array}{c}\text { Solids, } \\
\text { dissolved } \\
\text { (tons per } \\
\text { acre-feet) } \\
\text { (70303) }\end{array}$ & $\begin{array}{l}\text { Solids, } \\
\text { residue } \\
\text { at } 105 \\
\text { deg C, } \\
\text { total } \\
(\mathrm{mg} / \mathrm{L}) \\
(00500) \\
\end{array}$ & $\begin{array}{c}\text { Residue } \\
\text { at } 105 \\
\text { deg C, } \\
\text { dissolved } \\
\text { (mg/L) } \\
(00515)\end{array}$ & $\begin{array}{c}\text { Residue } \\
\text { at } 105 \\
\text { deg C, } \\
\text { suspended } \\
\text { (mg/L) } \\
(00530) \\
\end{array}$ & $\begin{array}{c}\text { Nitrogen, } \\
\text { ammonia, } \\
\text { dissolved } \\
\text { (mg/L } \\
\text { as } N) \\
(00608)\end{array}$ & $\begin{array}{c}\text { Nitrogen, } \\
\text { ammonia, } \\
\text { dissolved } \\
\text { (mg/L as } \\
\left.\mathrm{NH}_{4}\right) \\
(71846)\end{array}$ & $\begin{array}{l}\text { Nitrogen, } \\
\text { ammonia+ } \\
\text { organic, } \\
\text { dissolved } \\
\text { (mg/L } \\
\text { as N) } \\
(00623) \\
\end{array}$ & $\begin{array}{c}\text { Nitrogen, } \\
\mathrm{NO}_{2}+\mathrm{NO}_{3}, \\
\text { total } \\
(\mathrm{mg} / \mathrm{L} \\
\text { as } \mathrm{N}) \\
(00630)\end{array}$ & $\begin{array}{c}\mathrm{Nitrogen} \\
\mathrm{NO}_{2}+\mathrm{NO}_{3} \\
\text { dissolved } \\
(\mathrm{mg} / \mathrm{L} \\
\text { as } \mathrm{N}) \\
(00631) \\
\end{array}$ \\
\hline-- & -- & -- & -- & -- & -- & 0.480 & 0.62 & 0.98 & 0.100 & 0.100 \\
\hline -- & -- & -- & -- & -- & -- & -- & -- & -- & -- & -- \\
\hline -. & .- & .- & .- & -- & .- & .- & -- & .- & -- & .. \\
\hline 1,010 & 1,040 & 1.41 & -- & 1,020 & -- & -- & -- & -- & -- & -- \\
\hline -- & -- & -- & -. & -- & -- & -. & -- & -- & -- & $<0.100$ \\
\hline -- & -- & -- & -- & -- & -- & .- & -- & -. & .- & -- \\
\hline 991 & 1,010 & 1.37 & -- & 1,040 & -- & -- & -- & -- & -. & -- \\
\hline -- & -- & -- & - & -- & -- & -- & -- & -- & -- & $<0.100$ \\
\hline-- & -- & -- & - & -- & -- & -- & -- & -- & -- & -- \\
\hline -- & -- & -. & -- & -- & -- & -- & -- & -- & -- & -- \\
\hline -- & -- & -- & -- & -- & -. & -- & -- & -- & -- & $<0.100$ \\
\hline 998 & 1,030 & 1.40 & -- & 1,040 & -- & -- & -- & -. & -- & -- \\
\hline -- & -- & -- & -- & -- & -- & -- & -- & -- & -- & -- \\
\hline-- & -- & -. & -- & -- & -- & -- & -- & -- & -- & -. \\
\hline -- & -- & -. & -- & -- & -- & -- & -- & -- & -- & -- \\
\hline -- & -- & -- & -- & -- & -- & -- & -- & -- & -- & -- \\
\hline -. & -- & -- & -- & -- & -- & -- & -- & .- & -- & -- \\
\hline 1,020 & 1,030 & 1.40 & -- & 1,030 & -- & -- & -- & -- & -- & -- \\
\hline 1,020 & 1,030 & 1.40 & -- & 1,030 & -- & -- & -- & -- & -- & -- \\
\hline -- & -- & -- & -- & -- & -- & -. & -- & -- & 0.100 & 0.100 \\
\hline -- & -- & -. & -- & -- & -- & -- & -- & -- & -- & -- \\
\hline-- & -- & -- & -- & -- & -- & -- & -- & -- & -- &.- \\
\hline .. & -. & -- & -- & -. & -- & -- & -- & -- & -- & -- \\
\hline 970 & 1,030 & 1.40 & -- & 1,040 & -- & -- & -- & -- & .. & -- \\
\hline -- & -- & -- & -- & -- & -- & -- & -- & -- & .. & -- \\
\hline .- & -. & -. & -- & -- & -- & -- & -- & -- & 0.100 & 0.100 \\
\hline -- & -- & -- & -- & -- & -- & -- & -- & -- & - & -- \\
\hline-- & -- & -- & -- & -- & -- & -- & -- & -- & -- & -- \\
\hline 982 & 1,010 & 1.37 & -- & 1,020 & -- & -. & -- & -- & -- & -- \\
\hline -- & -- & -- & -- & -- & -- & -. & -- & -- & -- & -- \\
\hline .. & -- & -- & -- & .- & -- & -- & -- & - & -- & $<0.100$ \\
\hline-- & -- & -- & -- & -- & -- & -- & -- & -- & -- & -- \\
\hline-- & -- & -- & -- & -- & -- & -- & -- & -- & -- & -- \\
\hline-- & -- & -- & -- & .- & -- & 0.450 & 0.58 & 1.2 & -- & $<0.100$ \\
\hline 1,110 & 1,070 & 1.46 & 1,100 & 1,090 & 2 & -- & -- & -- & -- & - \\
\hline 981 & 1,050 & 1.43 & 1,080 & 1,100 & 4 & -- & -- & -- & -- & -. \\
\hline -- & -- & -- & -- & -. & -- & 0.890 & 1.1 & 1.3 & -- & $<0.100$ \\
\hline 1,030 & 1,070 & 1.46 & 1,080 & 1,080 & 6 & -- & -- & -- & -- & - \\
\hline-- & - & -- & -- & -- & -- & 0.440 & 0.57 & 1.0 & -- & $<0.100$ \\
\hline 1,080 & 1,060 & 1.44 & 1,080 & 1,080 & 15 & -- & -- & -- & -- & -- \\
\hline -- & -- & -- & -- & -- & -- & 0.430 & 0.55 & 0.97 & 0.100 & 0.100 \\
\hline 1,050 & 1,070 & 1.46 & -- & 1,050 & -- & -- & -- & -- & -- & -- \\
\hline -- & -- & -- & -- & -- & -- & -- & -- & - & -- & $<0.100$ \\
\hline 1,040 & 1,040 & 1.41 & -- & 1,090 & -- & -- & -- & -- & -- & -- \\
\hline -- & -- & -- & -- & -- & -- & -- & -- & -- & -- & $<0.100$ \\
\hline-- & -- & -- & -- & -- & -- & -- & -. & -- & -- & -- \\
\hline-- & -- & -- & -- & -- & -- & -- & -- & -- &.- & $<0.100$ \\
\hline
\end{tabular}


Table 9. Physical properties and concentrations of inorganic constituents, radioactive nuclides, and total organic carbon obtained from detailed samples-Continued

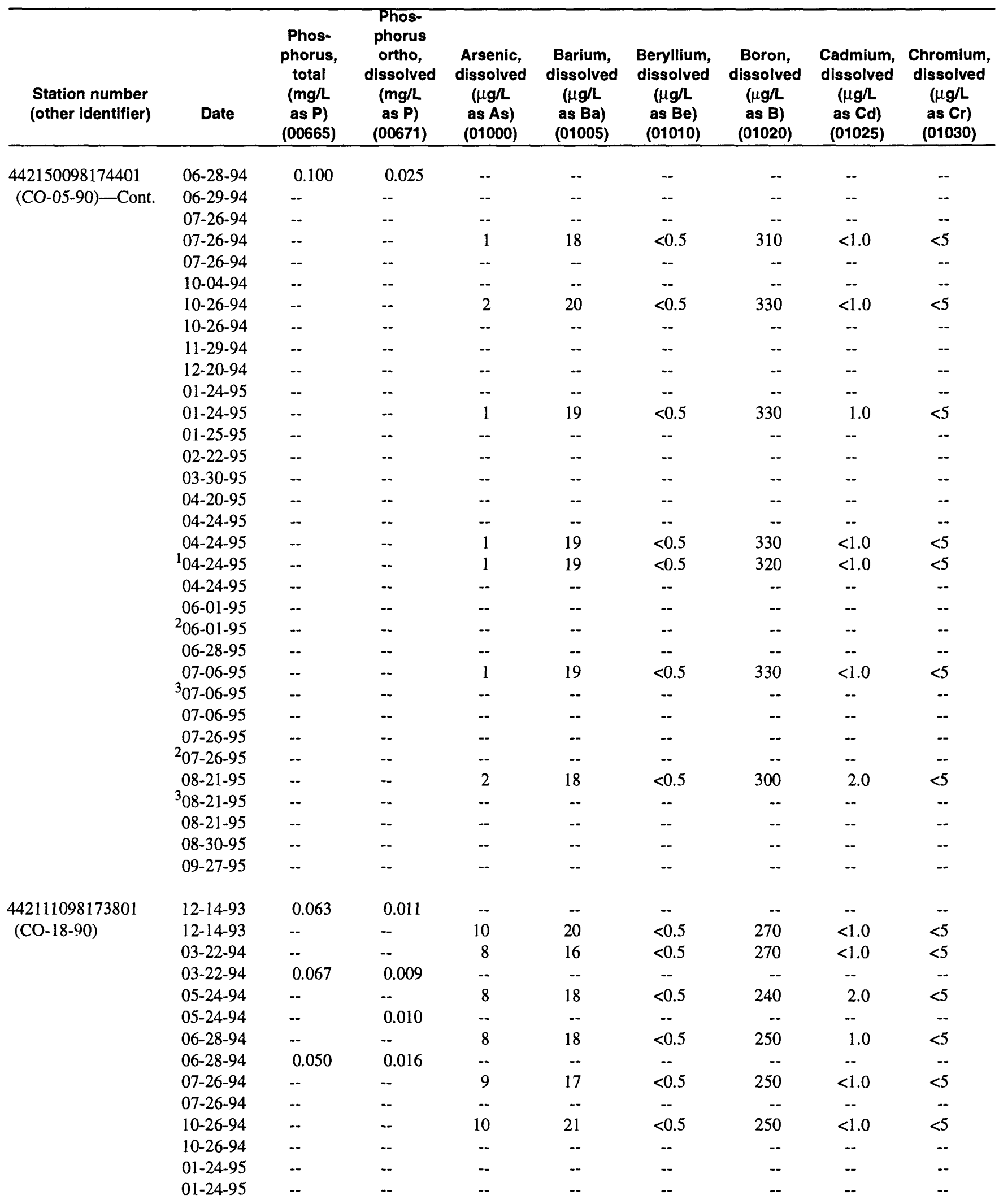




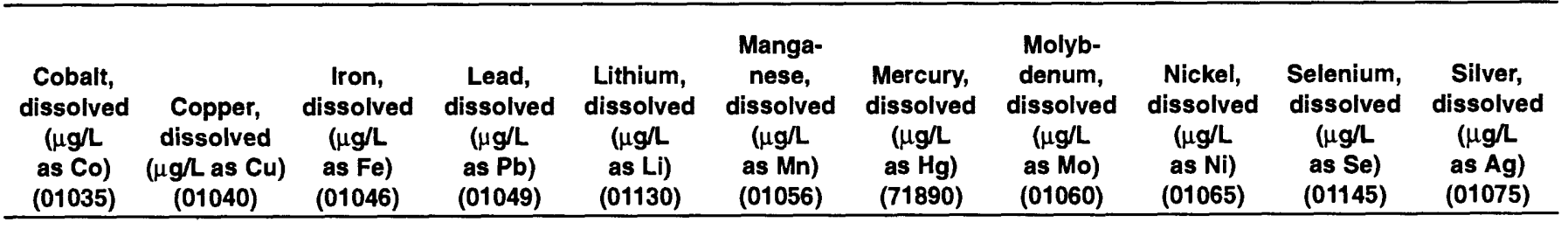

\begin{tabular}{|c|c|c|c|c|c|c|c|c|c|c|}
\hline -- & -- & -- & -- & -- & -- & -- & -- & -- & - & -- \\
\hline -- & -- & 1,200 & -- & -- & 400 & -- & -- & -- & -- & -- \\
\hline -- & -- & 1,200 & .- & -- & 430 & -- & -- & -- & -- & -- \\
\hline 10 & $<10$ & 1,100 & $<10$ & 76 & 410 & $<0.1$ & 10 & $<10$ & -- & 2.0 \\
\hline -- & -- & -- & -- & -- & -- & -- & -- & -- & -- & -- \\
\hline -. & -- & 1,100 & -- & -- & 430 & -- & -. & -- & -- & -- \\
\hline$<3$ & $<10$ & 1,200 & $<10$ & 92 & 420 & $<0.1$ & $<10$ & $<10$ & -- & 1.0 \\
\hline -- & -- & -- & -- & -- & -- & -- & -- & -- & -- & -- \\
\hline -- & -- & 1,200 & -- & -- & 440 & -- & -- & -. & -- & -- \\
\hline -- & -- & 1,900 & -- & -- & 180 & - & -- & -- & -- & -- \\
\hline-- & -- & -- & -- & -- & -- & -- & -- & -- & -. & -- \\
\hline$<3$ & $<10$ & 1,100 & $<10$ & 85 & 390 & $<0.1$ & $<10$ & $<10$ & -- & $<1.0$ \\
\hline -. & -- & 1,100 & -- & -- & 440 & -- & -- & -- & -- & -- \\
\hline -- & -- & 1,200 & -- & -- & 420 & -- & -- & -- & -- & -- \\
\hline -- & -- & 1,200 & -- & -- & 440 & -- & -- & -- & -- & -. \\
\hline -- & -- & 1,200 & -- & -- & 420 & -- & - & -- & -- & -- \\
\hline-- & -- & 1,200 & -- & - & 400 & -- & -- & -- & -- & -- \\
\hline$<3$ & $<10$ & 1,200 & $<10$ & 95 & 420 & $<0.1$ & 20 & $<10$ & -- & $<1.0$ \\
\hline 7 & $<10$ & 1,200 & $<10$ & 96 & 420 & $<0.1$ & $<10$ & 10 & -- & 2.0 \\
\hline -- & -- & -- & -- & -- & -- & -- & -- & -- & -- & -- \\
\hline- & -- & 1,100 & -- & -- & 410 & -- & -- & -- & -- & -- \\
\hline -- & -- & 1,100 & -- & -- & 430 & -- & -- & -- & -- & -- \\
\hline -- & -- & 1,100 & -- & -. & 410 & .- & -- & -. & -- & -- \\
\hline 6 & $<10$ & 1,200 & $<10$ & 91 & 400 & $<0.1$ & $<10$ & $<10$ & -- & $<1.0$ \\
\hline .. & -. & 1,200 & -- & -- & 420 & -- & -- & -- & -- & -- \\
\hline -- & -- & -- & -- & -- & -- & -- & -- & -- & -- & -- \\
\hline -- & -- & 1,200 & -- & -- & 410 & -- & -- & -- & -- & -- \\
\hline -- & -- & 1,200 & -- & -- & 420 & -- & - & -- & -- & -- \\
\hline 9 & $<10$ & 1,100 & 20 & 85 & 390 & $<0.1$ & 20 & 10 & -- & $<1.0$ \\
\hline -- & -- & 1,000 & -. & -- & 430 & -- & -- & -- & -- & -- \\
\hline -- & -- & -- & -- & -- & -- & -- & -- & -- & -- & -- \\
\hline -- & -- & 460 & -- & -- & 420 & -. & -- & -- & -- & -- \\
\hline -- & -- & 1,100 & -- & -- & 430 & -- & -- & -- & -- & -- \\
\hline -- & -- & -- & -- & -- & -- & -. & -- & -- & -- & -- \\
\hline$<3$ & $<10$ & 1,000 & $<10$ & 80 & 410 & $<0.1$ & $<10$ & $<10$ & $<1$ & $<1.0$ \\
\hline$<3$ & $<10$ & 1,200 & $<10$ & 80 & 370 & $<0.1$ & 20 & $<10$ & $<1$ & $<1.0$ \\
\hline-- & -- & -- & -- & -- & -- & -- & -- & -- & -- & -- \\
\hline$<3$ & $<10$ & 1,100 & $<10$ & 82 & 370 & $<0.1$ & 30 & $<10$ & $<1$ & $<1.0$ \\
\hline-- & -- & -- & -- & -- & -- & -- & -- & -- & -- & -- \\
\hline$<3$ & $<10$ & 1,100 & $<10$ & 84 & 380 & $<0.1$ & 10 & $<10$ & $<1$ & 1.0 \\
\hline-- & -- & -- & - & -- & -- & -- & .. & -- & -. & -- \\
\hline 20 & $<10$ & 1,100 & $<10$ & 75 & 390 & $<0.1$ & 30 & $<10$ & -- & $<1.0$ \\
\hline -. & -- & -- & -- & -- & -- & -- & -- & -- & -- & -- \\
\hline$<3$ & $<10$ & 1,200 & 20 & 92 & 410 & $<0.1$ & 20 & $<10$ & -- & 1.0 \\
\hline-- & - & -- & -- & -- & -- & -- & -- & -. & -- & - \\
\hline -- & -- & 1,200 & -- & -- & 400 & -- & - & - & -- & - \\
\hline-- & -- & -- & -- & -- & -- & -- & -- & -- & -- & -- \\
\hline
\end{tabular}


Table 9. Physical properties and concentrations of inorganic constituents, radioactive nuclides, and total organic carbon obtained from detailed samples-Continued

\begin{tabular}{|c|c|c|c|c|c|c|c|c|c|}
\hline $\begin{array}{l}\text { Station number } \\
\text { (other identifier) }\end{array}$ & Date & $\begin{array}{c}\text { Strontium, } \\
\text { dissolved } \\
(\mu g / L \\
\text { as Sr) } \\
(01080) \\
\end{array}$ & $\begin{array}{c}\text { Vanadium, } \\
\text { dissolved } \\
(\mu g / L \\
\text { as V) } \\
(01085) \\
\end{array}$ & $\begin{array}{c}\text { Zinc, } \\
\text { dissolved } \\
(\mu g / L \\
\text { as } \mathrm{Zn}) \\
(01090)\end{array}$ & $\begin{array}{l}\text { Gross } \\
\text { alpha, } \\
\text { dissolved } \\
\text { ( } \mu g / L \text { as } \\
\text { natural } \\
\text { uranium) } \\
(80030)\end{array}$ & $\begin{array}{c}\text { Alpha, } \\
\text { count, } \\
2 \text { sigma, } \\
\text { dissolved } \\
\text { as natural } \\
\text { uranium } \\
(\mu \mathrm{g} / \mathrm{L}) \\
(75986)\end{array}$ & $\begin{array}{c}\text { Alpha } \\
\text { radio, } \\
\text { dissolved } \\
\text { as } \\
\text { Th-230 } \\
\text { (pci/L) } \\
(04126) \\
\end{array}$ & $\begin{array}{c}\text { Alpha } \\
\text { count, } \\
2 \text { sigma, } \\
\text { dissolved } \\
\text { as } \\
\text { Th-230 } \\
\text { (pci/L) } \\
\text { (75987) }\end{array}$ & $\begin{array}{c}\text { Gross } \\
\text { alpha, } \\
\text { dissolved } \\
\text { (pci/l as } \\
\text { Unatural) } \\
\text { (01515) }\end{array}$ \\
\hline \multirow{33}{*}{$\begin{array}{l}442150098174401 \\
(\mathrm{CO}-05-90)\end{array}$} & $06-28-94$ & -- & -- & -- & -. & -- & -- & -- & 1.5 \\
\hline & $06-29-94$ & -. & -- & -- & -- & -- & -- & -- & -- \\
\hline & $07-26-94$ & - & -. & -- & -- & -- & -- & -- & -- \\
\hline & $07-26-94$ & 420 & $<6$ & $<3$ & -- & -- & - & -- & -- \\
\hline & $07-26-94$ & -- & -- & -- & -- & -- & -- & -- & -- \\
\hline & $10-04-94$ & .. & .- & -- & -- & -- & -- & -- & -- \\
\hline & $10-26-94$ & 450 & $<6$ & $<3$ & -- & -- & - & .- & -- \\
\hline & $10-26-94$ & -- & -. & .. & -. & .. & -. & -- & -- \\
\hline & $11-29-94$ & -- & -- & -- & -- & -- & -- & -- & -- \\
\hline & $12-20-94$ & -- & -- & -- & -- & -- & -- & -- & -- \\
\hline & $01-24-95$ & -- & .. & -. & -- & -- & .. & -- & -- \\
\hline & $01-24-95$ & 450 & $<6$ & $<3$ & -. & -- & -- & -- & -- \\
\hline & $01-25-95$ & -- & -- & -. & -- & -- & -- & -- & -- \\
\hline & $02-22-95$ & -- & .- & -. & -- & -- & -. & -.- & -- \\
\hline & $03-30-95$ & -- & -- & -. & -- & -- & -- & -- & -- \\
\hline & $04-20-95$ & -- & -- & -- & -- & -- & -- & -- & -- \\
\hline & $04-24-95$ & -- & -- & -. & -- & -- & -. & -- & -- \\
\hline & $04-24-95$ & 440 & $<6$ & $<3$ & -- & -- & -- & -- & -- \\
\hline & ${ }^{1} 04-24-95$ & 440 & $<6$ & 3 & -- & .- & -- & .- & -- \\
\hline & $04-24-95$ & -- & -- & -- & -- & -- & -- & -- & -- \\
\hline & 06-01-95 & -- & -- & -- & -- & -- & -. & -- & -- \\
\hline & ${ }^{2} 06-01-95$ & -. & -. & -- & -- & -- & -- & -- & -- \\
\hline & $06-28-95$ & -- & -- & -. & -- & -- & -- & -- & -- \\
\hline & $07-06-95$ & 430 & $<6$ & $<3$ & .- & .- & .- & -- & .- \\
\hline & ${ }^{3} 07-06-95$ & .. & -- & -- & -- & -- & -- & -- & -- \\
\hline & 07-06-95 & -. & -- & -- & -- & -- & -- & -- & -- \\
\hline & $07-26-95$ & -- & -- & -- & -- & -- & -- & -- & -- \\
\hline & ${ }^{2} 07-26-95$ & -. & -- & -- & -- & -- & -. & -- & -- \\
\hline & $08-21-95$ & 430 & $<6$ & $<3$ & -- & -- & -- & -- & -- \\
\hline & ${ }^{3} 08-21-95$ & -- & -- & -- & -.- & -- & -- & -- & -- \\
\hline & $08-21-95$ & -- & -- & -- & -- & -- & -- & -- & -- \\
\hline & $08-30-95$ & -- & -- & -- & -- & -- & -- & -- & -- \\
\hline & $09-27-95$ & -- & -- & -- & -- & -- & -- & -- & -- \\
\hline \multirow{14}{*}{$(\mathrm{CO}-18-90)$} & $12-14-93$ & -- & -- & -- & -- & -- & -- & -- & 5.0 \\
\hline & $12-14-93$ & 510 & $<6$ & $<3$ & 2.4 & 4.1 & 1.8 & 3.0 & -. \\
\hline & $03-22-94$ & 510 & $<6$ & $<3$ & 3.2 & 6.1 & 2.4 & 4.7 & -- \\
\hline & $03-22-94$ & -- & -- & -- & -- & - & -- & -- & 1.7 \\
\hline & $05-24-94$ & 500 & $<6$ & $<3$ & 3.1 & 6.3 & 2.2 & 4.5 & -- \\
\hline & $05-24-94$ & -- & -- & -- & -- & -- & -- & -- & 2.0 \\
\hline & $06-28-94$ & 500 & $<6$ & $<3$ & 5.5 & 6.6 & 3.9 & 4.6 & -- \\
\hline & $06-28-94$ & -- & -- & -- & -- & -- & -- & -. & 3.0 \\
\hline & $07-26-94$ & 490 & $<6$ & $<3$ & -- & -- & -- & -- & -- \\
\hline & $07-26-94$ & -- & -- & -- & -- & -- & -- & -- & -- \\
\hline & $10-26-94$ & 520 & $<6$ & $<3$ & -- & -- & -- & -- & -- \\
\hline & $10-26-94$ & -- & -- & -. & -- & -- & -- & -- & -- \\
\hline & $01-24-95$ & -- & -- & -- & -- & -- & -- & -- & -- \\
\hline & $01-24-95$ & -- & -- & -- & -- & -- & -- & -- & -- \\
\hline
\end{tabular}




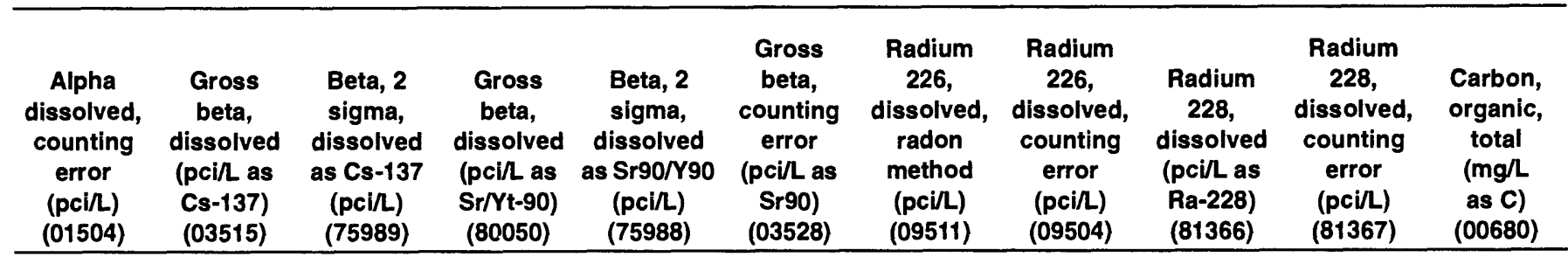

\begin{tabular}{|c|c|c|c|c|}
\hline -- & -- & -- & 18 & -- \\
\hline -- & -- & -- & -- & -- \\
\hline-- & -- & -- & -. & -- \\
\hline -- & -- & -- & -- & -- \\
\hline -- & -- & -- & -- & -- \\
\hline -- & -- & -- & -- & -. \\
\hline -- & -. & -- & -- & -- \\
\hline-- & -- & -- & -- & -- \\
\hline-- & -- & -- & -. & -- \\
\hline -- & -- & -- & -- & -- \\
\hline -- & -- & -- & -- & -- \\
\hline -- & -- & -- & -- & -- \\
\hline -- & -- & -- & -- & -- \\
\hline -- & -- & -- & - & -- \\
\hline -- & -- & -- & -- & -- \\
\hline-- & -- & -- & -- & -- \\
\hline -- & -- & -- & -- & -- \\
\hline -- & -- & -- & -- & -- \\
\hline -- & -- & -- & -- & -- \\
\hline -- & -- & -- & -- & -- \\
\hline -- & -- & -- & -- & -- \\
\hline -- & -- & -- & -- & -. \\
\hline -- & -- & -- & -- & -- \\
\hline -- & -- & -- & -- & -- \\
\hline -- & -- & -- & -- & -- \\
\hline -- & -- & -- & -- & -- \\
\hline-- & -- & -- & -. & -- \\
\hline -- & -- & -- & -- & -- \\
\hline -- & -- & -- & -- & -- \\
\hline -- & -. & -- & -- & -- \\
\hline -- & -- & -- & -- & -- \\
\hline -- & -- & -- & -- & -- \\
\hline -- & -- & -- & -- & -- \\
\hline
\end{tabular}

\begin{tabular}{|c|c|c|c|c|c|c|c|c|c|c|}
\hline 3.9 & -- & -- & 54 & -- & 10.4 & 0.30 & 0.3 & 0.80 & 0.20 & -- \\
\hline-- & 15 & 3.7 & 11 & 2.7 & -- & -- & -- & -- & -- & 5.1 \\
\hline -- & 14 & 3.4 & 10 & 2.5 & -- & -- & -- & -- & -- & 6.0 \\
\hline -- & -- & -- & 15 & -- & 7.7 & $<0.10$ & 0.1 & 1.2 & 0.40 & -- \\
\hline -- & 17 & 3.9 & 13 & 2.9 & -- & -- & -- & -- & -- & 5.4 \\
\hline -- & -- & -- & 38 & -- & 8.9 & 0.10 & 0.1 & 0.80 & 0.20 & -- \\
\hline-- & 15 & 3.6 & 11 & 2.7 & -- & -- & -- & -- & -- & 8.5 \\
\hline-- & -- & -- & 18 & -- & 7.7 & 2.1 & 0.4 & 1.9 & 0.60 & -- \\
\hline-- & -- & -- & -- & -- & -- & - & -- & -- & -- & -- \\
\hline-- & -- & -- & -- & -- & -- & -- & -- & -- & -- & -- \\
\hline- & - & $\cdots$ & -- & -- & -- & -- & $\cdots$ & -- & - & -- \\
\hline-- & -- & -- & -- & -- & -- & -- & -- & -- & - & -- \\
\hline- & -- & -- & -- & -- & -- & -- & -- & -- & -- & -- \\
\hline- & -- & -- & -- & -. & -- & - & -- & -- & -- & - \\
\hline
\end{tabular}


Table 9. Physical properties and concentrations of inorganic constituents, radioactive nuclides, and total organic carbon obtained from detailed samples-Continued

\begin{tabular}{|c|c|c|c|c|c|c|c|c|c|c|}
\hline \multirow{5}{*}{ (CO-18-90)-Cont. } & ${ }^{3} 07-06-95$ & USGS & SDSU & -- & - & -- & - & -- & -- & -- \\
\hline & 07-06-95 & USGS & SDDHL & -- & -- & -- & -- & - & -- & -- \\
\hline & $08-21-95$ & USGS & NWQL & 1,580 & 7.5 & 28.5 & 14.0 & -- & 725 & 0.1 \\
\hline & ${ }^{3} 08-21-95$ & USGS & SDSU & -- & -- & -- & -- & -- & -- & - \\
\hline & $08-21-95$ & USGS & SDDHL & -- & -- & -- & -- & -- & -- & -- \\
\hline
\end{tabular}




\begin{tabular}{|c|c|c|c|c|c|c|c|c|c|}
\hline $\begin{array}{l}\text { Dissolved } \\
\text { oxygen, } \\
\text { percent } \\
\text { saturation, } \\
\text { field } \\
(00301)\end{array}$ & $\begin{array}{l}\text { Oxidation- } \\
\text { reduction } \\
\text { potential, } \\
\text { field } \\
(\mathrm{mV}) \\
(00090)\end{array}$ & $\begin{array}{l}\text { Hardness, } \\
\text { total } \\
(\mathrm{mg} / \mathrm{L} \\
\left.\text { as } \mathrm{CaCO}_{3}\right) \\
(00900)\end{array}$ & $\begin{array}{l}\text { Alkalinity, } \\
\text { field, } \\
\text { dissolved, IT } \\
\text { (mg/L as } \\
\left.\mathrm{CaCO}_{3}\right) \\
(39086)\end{array}$ & $\begin{array}{c}\text { Colform, } \\
\text { fecal, } \\
0.7 \\
\mu \mathrm{m}-\mathrm{mf} \\
\text { (cols/ } \\
100 \mathrm{~mL}) \\
(31625)\end{array}$ & $\begin{array}{c}\text { Strep- } \\
\text { tococci } \\
\text { fecal, } \\
\text { KF agar } \\
\text { (cols per } \\
100 \mathrm{~mL} \text { ) } \\
(31673)\end{array}$ & $\begin{array}{c}\text { Calcium, } \\
\text { dissolved } \\
\text { (mg/h } \\
\text { as Ca) } \\
(00915)\end{array}$ & $\begin{array}{c}\text { Magnesium, } \\
\text { dissolved } \\
(\mathrm{mg} / \mathrm{L} \\
\text { as } \mathrm{Mg}) \\
(00925)\end{array}$ & $\begin{array}{c}\text { Sodium, } \\
\text { dissolved } \\
\text { (mg/l } \\
\text { as } \mathrm{Na}) \\
(00930)\end{array}$ & $\begin{array}{l}\text { Sodium } \\
\text { percent } \\
(00932)\end{array}$ \\
\hline -- & -. & 160 & -- & -- & -- & 46 & 12 & 300 & -- \\
\hline -. & -- & -- & -- & -- & -- & -- & -. & -. & -- \\
\hline 1 & -136 & 160 & 455 & 0 & 0 & 46 & 12 & 290 & 78 \\
\hline -- & -- & 160 & -- & -- & -- & 44 & 13 & 300 & -- \\
\hline -- & -- & -- & -- & -- & -- & -- & .- & -- & -- \\
\hline
\end{tabular}


Table 9. Physical properties and concentrations of inorganic constituents, radioactive nuclides, and total organic carbon obtained from detailed samples-Continued

\begin{tabular}{|c|c|c|c|c|c|c|c|c|c|}
\hline $\begin{array}{l}\text { Station number } \\
\text { (other identifier) }\end{array}$ & Date & $\begin{array}{l}\text { Sodium } \\
\text { adsorp- } \\
\text { tion } \\
\text { ratio } \\
(00931)\end{array}$ & $\begin{array}{c}\text { Potassium, } \\
\text { dissolved } \\
\text { (mg/L } \\
\text { as K) } \\
(00935)\end{array}$ & $\begin{array}{l}\text { Bicar- } \\
\text { bonate, } \\
\text { field, } \\
\text { dissolved, } \\
\text { IT }(\mathrm{mg} / \mathrm{L} \\
\left.\text { as } \mathrm{HCO}_{3}\right) \\
(00453)\end{array}$ & $\begin{array}{l}\text { Carbonate, } \\
\text { field, } \\
\text { dissolved, } \\
\text { IT (mg/L } \\
\left.\text { as } \mathrm{CO}_{3}\right) \\
(00452)\end{array}$ & $\begin{array}{c}\text { Sulfate, } \\
\text { dissolved } \\
(\mathrm{mg} / \mathrm{L} \\
\left.\text { as } \mathrm{SO}_{4}\right) \\
(00945)\end{array}$ & $\begin{array}{c}\text { Chloride, } \\
\text { dissolved } \\
\text { (mg/L } \\
\text { as Cl) } \\
(00940)\end{array}$ & $\begin{array}{c}\text { Fluoride, } \\
\text { dissolved } \\
\text { (mg/L } \\
\text { as F) } \\
(00950)\end{array}$ & $\begin{array}{c}\text { Silica, } \\
\text { dissolved } \\
(\mathrm{mg} / \mathrm{L} \text { as } \\
\left.\mathrm{SiO}_{2}\right) \\
(00955)\end{array}$ \\
\hline & ${ }^{3} 07-06-95$ & 10 & -- & -- & -- & -- & 31 & -- & -- \\
\hline & $07-06-95$ & -- & -- & -- & -- & -- & -- & - & -- \\
\hline & $08-21-95$ & 10 & 11 & 555 & 0 & 320 & 29 & 0.50 & 29 \\
\hline & ${ }^{3} 08-21-95$ & 10 & -- & -- & -- & -- & 31 & - & -- \\
\hline & $08-21-95$ & -- & - &.- & -- & -- & -- & -- & -- \\
\hline
\end{tabular}




\begin{tabular}{|c|c|c|c|c|c|c|c|c|c|c|}
\hline $\begin{array}{l}\text { Solids, } \\
\text { sum of con- } \\
\text { stituents, } \\
\text { dissolved } \\
(\mathrm{mg} / \mathrm{L}) \\
(70301) \\
\end{array}$ & $\begin{array}{l}\text { Solids, } \\
\text { residue } \\
\text { at } 180 \\
\text { deg C, } \\
\text { dissolved } \\
\text { (mg/L) } \\
(70300)\end{array}$ & $\begin{array}{c}\text { Solids, } \\
\text { dissolved } \\
\text { (tons per } \\
\text { acre-feet). } \\
(70303)\end{array}$ & $\begin{array}{l}\text { Solids, } \\
\text { residue } \\
\text { at } 105 \\
\text { deg } \mathrm{C} \text {, } \\
\text { total } \\
(\mathrm{mg} / \mathrm{L}) \\
(00500)\end{array}$ & $\begin{array}{c}\text { Residue } \\
\text { at } 105 \\
\text { deg C, } \\
\text { dissolved } \\
(\mathrm{mg} / \mathrm{L}) \\
(00515)\end{array}$ & $\begin{array}{c}\text { Residue } \\
\text { at } 105 \\
\text { deg C, } \\
\text { suspended } \\
(\mathrm{mg} / \mathrm{L}) \\
(00530)\end{array}$ & $\begin{array}{c}\text { Nitrogen, } \\
\text { ammonia, } \\
\text { dissolved } \\
\text { (mg/h } \\
\text { as N) } \\
(00608)\end{array}$ & $\begin{array}{c}\text { Nitrogen, } \\
\text { ammonia, } \\
\text { dissolved } \\
\text { (mg/L as } \\
\left.\mathrm{NH}_{4}\right) \\
(71846)\end{array}$ & $\begin{array}{l}\text { Nitrogen, } \\
\text { ammonia+ } \\
\text { organic, } \\
\text { dissolved } \\
(\mathrm{mg} / \mathrm{L} \\
\text { as } \mathrm{N}) \\
(00623)\end{array}$ & $\begin{array}{c}\text { Nitrogen, } \\
\mathrm{NO}_{2}+\mathrm{NO}_{3}, \\
\text { total } \\
\text { (mg/L } \\
\text { as } \mathrm{N}) \\
(00630)\end{array}$ & $\begin{array}{c}\text { Nitrogen, } \\
\mathrm{NO}_{2}+\mathrm{NO}_{3} \text {, } \\
\text { dissolved } \\
(\mathrm{mg} / \mathrm{L} \\
\text { as N) } \\
(00631)\end{array}$ \\
\hline 1,000 & 1,070 & 1.46 & -. & 1,070 & -. & -- & -. & -- & -- & .- \\
\hline 1,020 & 1,070 & 1.46 & -. & 1,060 & - & - & -- & -- & -- & -- \\
\hline -- & -- & -- & -- & -- & -. & -- & -. & -. & -- & -- \\
\hline -- & -. & -. & -- & -- & -- & -. & -. & -- & 0.100 & 0.100 \\
\hline 1,010 & 1,060 & 1.44 & -- & 1,060 & -- & -- & -- & -- & -- & -- \\
\hline -- & -- & -- & -- & -- & - & -- & -- & -- & -- & -. \\
\hline-- & - & - & -- & - & - & - & -- & -- & -- & $<0.100$ \\
\hline
\end{tabular}


Table 9. Physical properties and concentrations of inorganic constituents, radioactive nuclides, and total organic carbon obtained from detailed samples-Continued

\begin{tabular}{|c|c|c|c|c|c|c|c|c|c|}
\hline $\begin{array}{l}\text { Station number } \\
\text { (other identifier) }\end{array}$ & Date & $\begin{array}{c}\text { Phos- } \\
\text { phorus, } \\
\text { total } \\
\text { (mg/L } \\
\text { as P) } \\
(00665)\end{array}$ & $\begin{array}{l}\text { Phos- } \\
\text { phorus } \\
\text { ortho, } \\
\text { dissolved } \\
\text { (mg/L } \\
\text { as P) } \\
(00671)\end{array}$ & $\begin{array}{c}\text { Arsenic, } \\
\text { dissolved } \\
(\mu \mathrm{g} / \mathrm{L} \\
\text { as As) } \\
(01000)\end{array}$ & $\begin{array}{c}\text { Barium, } \\
\text { dissolved } \\
(\mu \mathrm{g} / \mathrm{L} \\
\text { as } \mathrm{Ba}) \\
(01005)\end{array}$ & $\begin{array}{c}\text { Beryllium, } \\
\text { dissolved } \\
(\mu g / L \\
\text { as Be }) \\
(01010)\end{array}$ & $\begin{array}{c}\text { Boron, } \\
\text { dissolved } \\
(\mu \mathrm{g} / \mathrm{L} \\
\text { as B) } \\
(01020)\end{array}$ & $\begin{array}{c}\text { Cadmium, } \\
\text { dissolved } \\
(\mu g / L \\
\text { as Cd }) \\
(01025)\end{array}$ & $\begin{array}{c}\text { Chromium, } \\
\text { dissolved } \\
(\mu g / L \\
\text { as Cr) } \\
(01030)\end{array}$ \\
\hline \multirow{5}{*}{$\begin{array}{l}442111098173801 \\
\text { (CO-18-90)-Cont. }\end{array}$} & ${ }^{3} 07-06-95$ & -- & -- & -- & -- & -- & -- & -- & -- \\
\hline & $07-06-95$ & -- & -- & - & .- & -- & -- & -- & -- \\
\hline & $08-21-95$ & -- & -- & 9 & 17 & $<0.5$ & 250 & $<1.0$ & $<5$ \\
\hline & ${ }^{3} 08-21-95$ & -. & -- & -- & -. & -- & -- & -- & -- \\
\hline & $08-21-95$ & -- & -- & -- & -- & -- & -- & -- & -- \\
\hline
\end{tabular}




\begin{tabular}{|c|c|c|c|c|c|c|c|c|c|c|}
\hline $\begin{array}{c}\text { Cobalt, } \\
\text { dissolved } \\
(\mu \mathrm{g} / \\
\text { as Co) } \\
(01035)\end{array}$ & $\begin{array}{c}\text { Copper, } \\
\text { dissolved } \\
(\mu g / L \text { as } \mathrm{Cu}) \\
(01040)\end{array}$ & $\begin{array}{c}\text { Iron, } \\
\text { dissolved } \\
(\mu \mathrm{g} / \mathrm{L} \\
\text { as Fe) } \\
(01046)\end{array}$ & $\begin{array}{c}\text { Lead, } \\
\text { dissolved } \\
(\mu \mathrm{g} / \mathrm{L} \\
\text { as } \mathrm{Pb}) \\
(01049)\end{array}$ & $\begin{array}{c}\text { Lithium, } \\
\text { dissolved } \\
(\mu g / L \\
\text { as } \mathrm{Li}) \\
(01130)\end{array}$ & $\begin{array}{l}\text { Manga- } \\
\text { nese, } \\
\text { dissolved } \\
(\mu g / L \\
\text { as Mn) } \\
(01056)\end{array}$ & $\begin{array}{c}\text { Mercury, } \\
\text { dissolved } \\
(\mu \mathrm{g} / \mathrm{L} \\
\text { as } \mathrm{Hg}) \\
(71890)\end{array}$ & $\begin{array}{c}\text { Molyb- } \\
\text { denum, } \\
\text { dissolved } \\
(\mu \mathrm{gl} \text {. } \\
\text { as Mo) } \\
(01060)\end{array}$ & $\begin{array}{c}\text { Nickel, } \\
\text { dissolved } \\
(\mu \mathrm{g} / \mathrm{L} \\
\text { as } \mathrm{Ni}) \\
(01065)\end{array}$ & $\begin{array}{c}\text { Selenium, } \\
\text { dissolved } \\
(\mu g / L \\
\text { as Se) } \\
(01145)\end{array}$ & $\begin{array}{c}\text { Silver, } \\
\text { dissolved } \\
(\mu \mathrm{g} / \mathrm{L} \\
\text { as Ag) } \\
(01075)\end{array}$ \\
\hline$<3$ & $<10$ & 1,100 & $<10$ & 84 & 360 & 0.1 & 20 & $<10$ & -- & $<1.0$ \\
\hline -- & -- & 1,100 & -- & -- & 400 & -- & -- & -- & -- & -- \\
\hline -- & -- & -. & -- & -- & -- & -- & -- & -- & -- & -- \\
\hline 8 & $<10$ & 1,200 & $<10$ & 84 & 380 & $<0.1$ & 30 & 10 & - & $<1.0$ \\
\hline -- & -- & 350 & -- & -- & 410 & -- & -- & -- & - & -- \\
\hline -- & -- & -- & -- & -- & -- & -- & -- & -- & -- & -- \\
\hline
\end{tabular}


Table 9. Physical properties and concentrations of inorganic constituents, radioactive nuclides, and total organic carbon obtained from detailed samples-Continued

\begin{tabular}{|c|c|c|c|c|c|c|c|c|c|}
\hline $\begin{array}{l}\text { Station number } \\
\text { (other identifier) }\end{array}$ & Date & $\begin{array}{c}\text { Strontium, } \\
\text { dissolved } \\
(\mu g / L \\
\text { as Sr) } \\
(01080)\end{array}$ & $\begin{array}{c}\text { Vanadium, } \\
\text { dissolved } \\
(\mu \mathrm{g} / \mathrm{L} \\
\text { as V) } \\
(01085) \\
\end{array}$ & $\begin{array}{c}\text { Zinc, } \\
\text { dissolved } \\
(\mu g / L \\
\text { as } \mathrm{Zn}) \\
(01090) \\
\end{array}$ & $\begin{array}{c}\text { Gross } \\
\text { alpha, } \\
\text { dissolved } \\
\text { ( } \mu g / L \text { as } \\
\text { natural } \\
\text { uranium) } \\
(80030)\end{array}$ & $\begin{array}{c}\text { Alpha, } \\
\text { count, } \\
2 \text { sigma, } \\
\text { dissolved } \\
\text { as natural } \\
\text { uranium } \\
(\mu g / L) \\
(75986)\end{array}$ & $\begin{array}{c}\text { Alpha } \\
\text { radio, } \\
\text { dissolved } \\
\text { as } \\
\text { Th-230 } \\
\text { (pci/l) } \\
(04126) \\
\end{array}$ & $\begin{array}{c}\text { Alpha } \\
\text { count, } \\
2 \text { sigma, } \\
\text { dissolved } \\
\text { as } \\
\text { Th-230 } \\
\text { (pci/L) } \\
(75987)\end{array}$ & $\begin{array}{c}\text { Gross } \\
\text { alpha, } \\
\text { dissolved } \\
\text { (pcill as } \\
\text { U-natural) } \\
\text { (01515) }\end{array}$ \\
\hline \multirow{5}{*}{ (CO-18-90)-Cont. } & 07-06-95 & 500 & $<6$ & $<3$ & -- & -- & -. & - & -- \\
\hline & ${ }^{3} 07-06-95$ & -- & -- & -- & -- & -- & -- & -- & -. \\
\hline & 07-06-95 & -- & -- & -- & -- & -- & -- & -- & -- \\
\hline & $08-21-95$ & 510 & $<6$ & $<3$ & -- & -- & -- & - & -- \\
\hline & ${ }^{3} 08-21-95$ & -- & -- & -- & - & -- & -- & -- & - \\
\hline
\end{tabular}

${ }^{1}$ Indicates duplicate sample pair sent to NWQL for quality-assurance purposes.

${ }^{2}$ Indicates blind sample for quality-assurance purposes.

${ }^{3}$ Indicates replicate sample pairs sent to SDSU and NWQL for quality-assurance purposes. 


\begin{tabular}{|c|c|c|c|c|c|c|c|c|c|c|}
\hline $\begin{array}{c}\text { Alpha } \\
\text { dissolved, } \\
\text { counting } \\
\text { error } \\
\text { (pcin) } \\
(01504) \\
\end{array}$ & $\begin{array}{c}\text { Gross } \\
\text { beta, } \\
\text { dissolved } \\
\text { (pcin as as } \\
\text { Cs-137) } \\
(03515) \\
\end{array}$ & $\begin{array}{c}\text { Beta, } 2 \\
\text { sigma, } \\
\text { dissolved } \\
\text { as Cs-137 } \\
\text { (pci/L) } \\
(75989) \\
\end{array}$ & $\begin{array}{c}\text { Gross } \\
\text { beta, } \\
\text { dissolved } \\
\text { (pcill as } \\
\text { Sr/Yt-90) } \\
(80050)\end{array}$ & $\begin{array}{c}\text { Beta, } 2 \\
\text { sigma, } \\
\text { dissolved } \\
\text { as Sr90/Y90 } \\
(\mathrm{pci} / \mathrm{L}) \\
(75988)\end{array}$ & $\begin{array}{c}\text { Gross } \\
\text { beta, } \\
\text { counting } \\
\text { error } \\
\text { (pcil as } \\
\text { Sr90) } \\
(03528) \\
\end{array}$ & $\begin{array}{l}\text { Radium } \\
226, \\
\text { dissolved, } \\
\text { radon } \\
\text { method } \\
\text { (pci/) } \\
(09511) \\
\end{array}$ & $\begin{array}{l}\text { Radium } \\
226, \\
\text { dissolved, } \\
\text { counting } \\
\text { error } \\
\text { (pci/ }) \\
(09504) \\
\end{array}$ & $\begin{array}{c}\text { Radium } \\
228, \\
\text { dissolved } \\
\text { (pci/L as } \\
\text { Ra-228) } \\
(81366) \\
\end{array}$ & $\begin{array}{l}\text { Radium } \\
\text { 228, } \\
\text { dissolved, } \\
\text { counting } \\
\text { error } \\
\text { (pci/L) } \\
\text { (81367) } \\
\end{array}$ & $\begin{array}{c}\text { Carbon, } \\
\text { organic } \\
\text { total } \\
\text { (mg/l } \\
\text { as C) } \\
(00680)\end{array}$ \\
\hline-- & -- & - & - & -- & - & -- & -- & - & -- & -- \\
\hline -- & -- & -- & -- & -- & -. & -- & -- & -- & -- & -- \\
\hline-- & -- & -- & -- & -- & -- & -- & -- & -- & -- & -- \\
\hline -- & -- & -- & -- & -- & -- & -- & -- & -- & -- & -- \\
\hline- & - & -- & - & -- & - & -- & - & -- & -- & -- \\
\hline- & -- & -- & -- & -- & -- & -- & -- & -- & -- & -- \\
\hline-- & -- & -- & -- & -- & -- & -- & -- & -- & -- & - \\
\hline
\end{tabular}


(This page intentionally left blank.) 
Table 10. Concentrations of dicamba, picloram, and chlorophenoxy-acid herbicides obtained from detailed samples

[All analyses on unfiltered samples. All samples collected by U.S. Geological Survey and analyzed by National Water Quality Laboratory. $\mu \mathrm{g} / \mathrm{L}$, micrograms per liter; <, less than]

\begin{tabular}{|c|c|c|c|c|c|c|c|}
\hline $\begin{array}{l}\text { Station number } \\
\text { (other identifier) }\end{array}$ & Date & $\begin{array}{c}\text { Dicamba } \\
\text { (Mediben) } \\
\text { (Ban Vel D) } \\
(\mu g / L) \\
(82052)\end{array}$ & $\begin{array}{c}\text { Picloram } \\
\text { (Tordon) } \\
\text { (Amdon) } \\
(\mu g / L) \\
(39720)\end{array}$ & $\begin{array}{c}\text { Silvex } \\
(\mu g / L) \\
(39760)\end{array}$ & $\begin{array}{c}2,4-D \\
(\mu g / L) \\
(39730)\end{array}$ & $\begin{array}{c}2,4,5-T \\
(\mu g / L) \\
(39740)\end{array}$ & $\begin{array}{c}2,4-D P \\
(\mu g / L) \\
(82183)\end{array}$ \\
\hline 42150098120601 & $03-22-94$ & 0.04 & $<0.01$ & $<0.01$ & 0.39 & $<0.01$ & $<0.01$ \\
\hline (James River at & $05-02-94$ & 0.02 & 0.04 & $<0.01$ & $<0.01$ & $<0.01$ & $<0.01$ \\
\hline 442150098120602 & $03-22-94$ & $<0.01$ & $<0.01$ & $<0.01$ & $<0.01$ & $<0.01$ & $<0.01$ \\
\hline (Huron Water Treatment & $05-02-94$ & $<0.01$ & $<0.01$ & $<0.01$ & $<0.01$ & $<0.01$ & $<0.01$ \\
\hline Plant effluent) & $06-28-94$ & 0.05 & $<0.01$ & $<0.01$ & $<0.01$ & $<0.01$ & $<0.01$ \\
\hline 442150098174401 & $12-14-93$ & $<0.01$ & $<0.01$ & $<0.01$ & $<0.01$ & $<0.01$ & $<0.01$ \\
\hline 442111098173801 & $12-14-93$ & $<0.01$ & $<0.01$ & $<0.01$ & $<0.01$ & $<0.01$ & $<0.01$ \\
\hline$(\mathrm{CO}-18-90)$ & $03-22-94$ & $<0.01$ & $<0.01$ & $<0.01$ & $<0.01$ & $<0.01$ & $<0.01$ \\
\hline
\end{tabular}


Table 11. Concentrations of organochlorine insecticides, gross polychlorinated biphenols (PCB's), and gross polychlorinated naphthalenes (PCN's) obtained from detailed samples

[All analyses on unfiltered samples. All samples collected by U.S. Geological Survey and analyzed by National Water Quality Laboratory. $\mu \mathrm{g} / \mathrm{L}$, micrograms per liter; <, less than]

\begin{tabular}{|c|c|c|c|c|c|c|c|c|}
\hline $\begin{array}{l}\text { Station number } \\
\text { (other identifier) }\end{array}$ & Date & $\begin{array}{c}\text { Aldrin } \\
(\mu \mathrm{g} / \mathrm{L}) \\
(39330) \\
\end{array}$ & $\begin{array}{c}\text { Chlordane } \\
(\mu g / L) \\
(39350) \\
\end{array}$ & $\begin{array}{c}\text { DDD } \\
(\mu g / L) \\
(39360)\end{array}$ & $\begin{array}{c}\text { DDE } \\
(\mu g / L) \\
(39365) \\
\end{array}$ & $\begin{array}{c}\text { DDT } \\
(\mu g / L) \\
(39370)\end{array}$ & $\begin{array}{c}\text { Dieldrin } \\
(\mu g / L) \\
(39380) \\
\end{array}$ & $\begin{array}{l}\text { Endo- } \\
\text { sulfan } \\
(\mu g / L) \\
(39388) \\
\end{array}$ \\
\hline \multirow{4}{*}{$\begin{array}{c}42150098120601 \\
\text { (James River at } \\
\text { Morningside) }\end{array}$} & $03-22-94$ & $<0.010$ & $<0.1$ & $<0.010$ & $<0.010$ & $<0.010$ & $<0.010$ & $<0.010$ \\
\hline & $05-02-94$ & $<0.010$ & $<0.1$ & $<0.010$ & $<0.010$ & $<0.010$ & $<0.010$ & $<0.010$ \\
\hline & $05-24-94$ & $<0.010$ & $<0.1$ & $<0.010$ & $<0.010$ & $<0.010$ & $<0.010$ & $<0.010$ \\
\hline & $06-28-94$ & $<0.010$ & $<0.1$ & $<0.010$ & $<0.010$ & $<0.010$ & $<0.010$ & $<0.010$ \\
\hline \multirow{4}{*}{$\begin{array}{l}442150098120602 \\
\text { (Huron Water } \\
\text { Treatment Plant } \\
\text { effluent) }\end{array}$} & $03-22-94$ & $<0.010$ & $<0.1$ & $<0.010$ & $<0.010$ & $<0.010$ & $<0.010$ & $<0.010$ \\
\hline & $05-02-94$ & $<0.010$ & $<0.1$ & $<0.010$ & $<0.010$ & $<0.010$ & $<0.010$ & $<0.010$ \\
\hline & $05-24-94$ & $<0.010$ & $<0.1$ & $<0.010$ & $<0.010$ & $<0.010$ & $<0.010$ & $<0.010$ \\
\hline & $06-28-94$ & $<0.010$ & $<0.1$ & $<0.010$ & $<0.010$ & $<0.010$ & $<0.010$ & $<0.010$ \\
\hline \multirow{4}{*}{$\begin{array}{c}42150098174401 \\
(\mathrm{CO}-05-90)\end{array}$} & $12-14-93$ & $<0.010$ & $<0.1$ & $<0.010$ & $<0.010$ & $<0.010$ & $<0.010$ & $<0.010$ \\
\hline & $03-22-94$ & $<0.010$ & $<0.1$ & $<0.010$ & $<0.010$ & $<0.010$ & $<0.010$ & $<0.010$ \\
\hline & $05-24-94$ & $<0.010$ & $<0.1$ & $<0.010$ & $<0.010$ & $<0.010$ & $<0.010$ & $<0.010$ \\
\hline & $06-28-94$ & $<0.010$ & $<0.1$ & $<0.010$ & $<0.010$ & $<0.010$ & $<0.010$ & $<0.010$ \\
\hline \multirow{3}{*}{$\begin{array}{c}42111098173801 \\
(\mathrm{CO}-18-90)\end{array}$} & $12-14-93$ & $<0.010$ & $<0.1$ & $<0.010$ & $<0.010$ & $<0.010$ & $<0.010$ & $<0.010$ \\
\hline & $03-22-94$ & $<0.010$ & $<0.1$ & $<0.010$ & $<0.010$ & $<0.010$ & $<0.010$ & $<0.010$ \\
\hline & $05-24-94$ & $<0.010$ & $<0.1$ & $<0.010$ & $<0.010$ & $<0.010$ & $<0.010$ & $<0.010$ \\
\hline
\end{tabular}




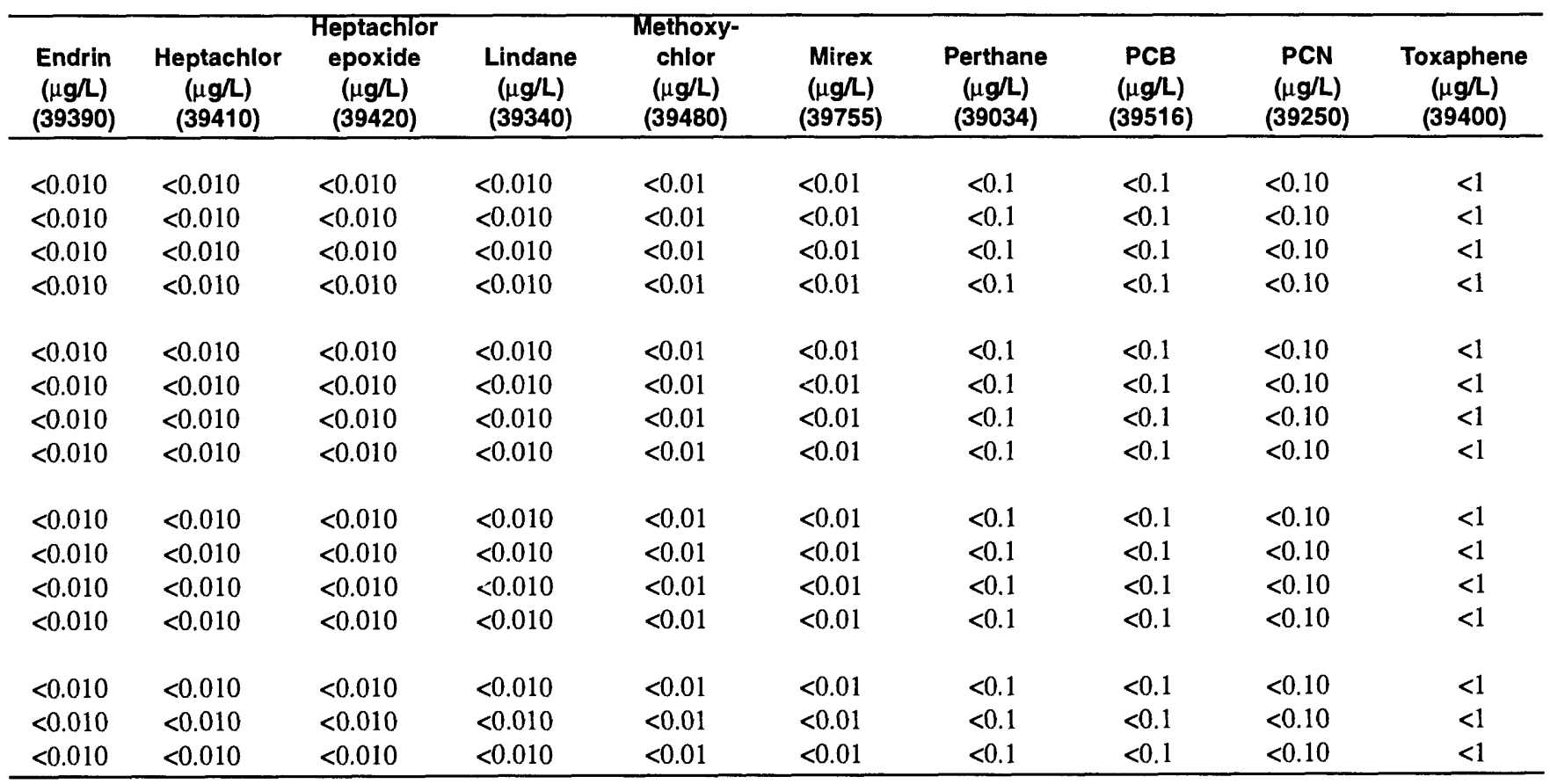


Table 12. Concentrations of volatile organic compounds obtained from detailed samples

[All analyses on unfiltered samples. All samples collected by U.S. Geological Survey and analyzed by National Water Quality Laboratory. $\mu \mathrm{g} / \mathrm{L}$, micrograms per liter; <, less than]

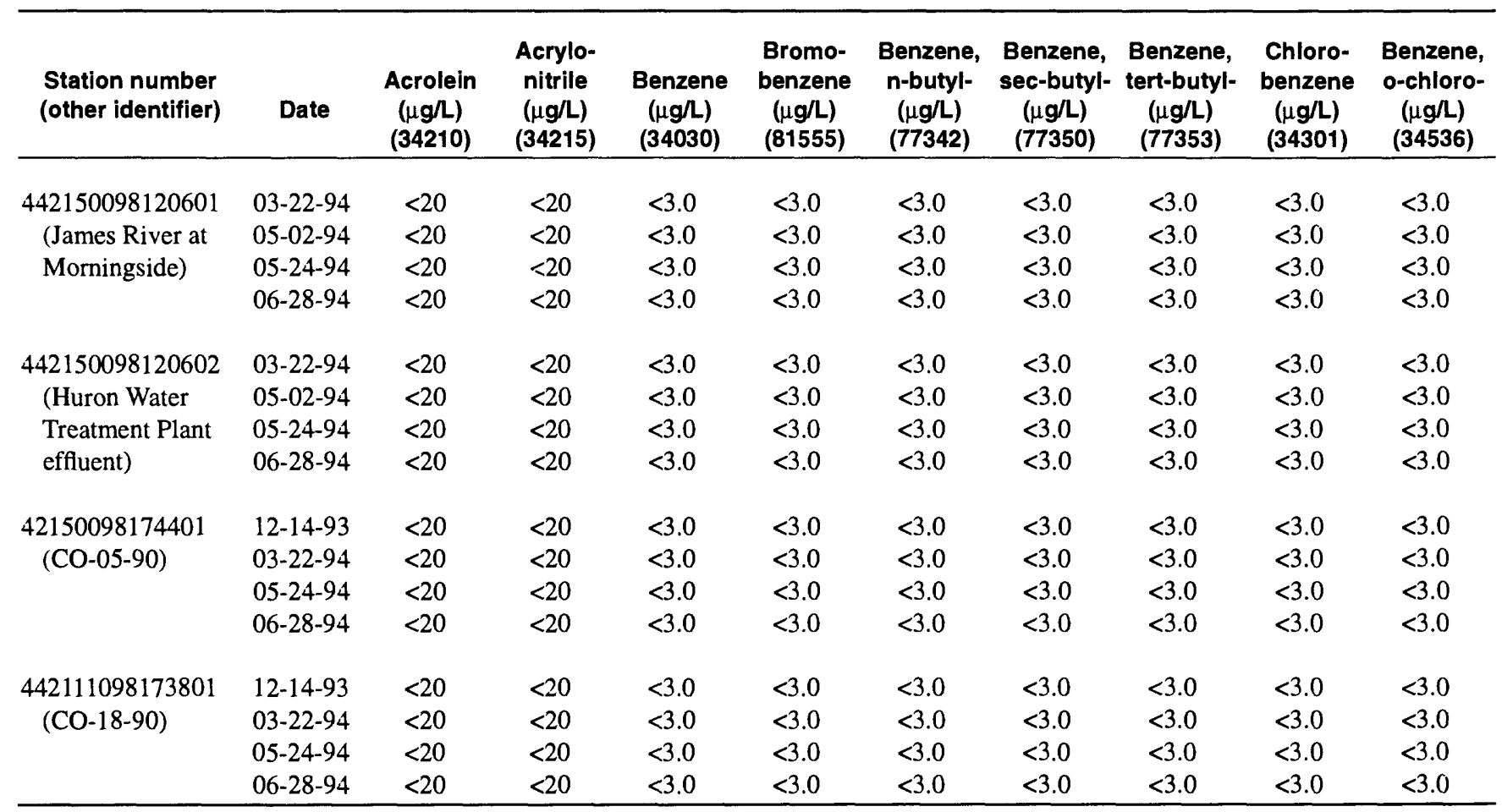

104

Hydrologic Data for 1994-96 for the Huron Project of the High Plains Ground-Water Demonstration Program 


\begin{tabular}{|c|c|c|c|c|c|c|c|c|c|c|c|}
\hline $\begin{array}{c}\text { Benzene, } \\
\text { 1,3-di- } \\
\text { chloro- } \\
(\mu g / L) \\
(34566)\end{array}$ & $\begin{array}{c}\text { Benzene, } \\
\text { 1,4-di- } \\
\text { chloro- } \\
(\mu g / L) \\
(34571)\end{array}$ & $\begin{array}{c}\text { Benzene, } \\
\text { 1,2,3-tri- } \\
\text { chloro- } \\
\text { ( } \mu \mathrm{g} / \mathrm{L}) \\
(77613)\end{array}$ & $\begin{array}{c}\text { Benzene, } \\
\text { 1,2,4-tri- } \\
\text { chloro- } \\
\left(\mu g^{\prime} L\right) \\
(\mathbf{3 4 5 5 1 )}\end{array}$ & $\begin{array}{c}\text { Ethyl- } \\
\text { benzene } \\
(\mu \mathrm{g} / \mathrm{L}) \\
(\mathbf{3 4 3 7 1 )}\end{array}$ & $\begin{array}{c}\text { Benzene, } \\
\text { n-propyl- } \\
(\mu g / L) \\
(77224)\end{array}$ & $\begin{array}{c}\text { Tso- } \\
\text { propyl- } \\
\text { benzene } \\
(\mu g / L) \\
(77223)\end{array}$ & $\begin{array}{c}\text { Methyl- } \\
\text { bromide } \\
(\mu g / L) \\
(34413)\end{array}$ & $\begin{array}{c}\text { Bromo- } \\
\text { form } \\
(\mu \mathrm{g} / \mathrm{L}) \\
(32104)\end{array}$ & $\begin{array}{c}\text { Hexa- } \\
\text { chloro- } \\
\text { butadiene } \\
(\mu g / L) \\
(39702)\end{array}$ & $\begin{array}{c}\text { Carbon } \\
\text { tetra- } \\
\text { chloride } \\
(\mu g / L) \\
(32102)\end{array}$ & $\begin{array}{c}\text { Methyl- } \\
\text { chloride } \\
(\mu g / L) \\
(34418)\end{array}$ \\
\hline$<3.0$ & $<3.0$ & $<3.0$ & $<3.0$ & $<3.0$ & $<3.0$ & $<3.0$ & $<3.0$ & $<3.0$ & $<3.0$ & $<3.0$ & $<3.0$ \\
\hline$<3.0$ & $<3.0$ & $<3.0$ & $<3.0$ & $<3.0$ & $<3.0$ & $<3.0$ & $<3.0$ & $<3.0$ & $<3.0$ & $<3.0$ & $<3.0$ \\
\hline$<3.0$ & $<3.0$ & $<3.0$ & $<3.0$ & $<3.0$ & $<3.0$ & $<3.0$ & $<3.0$ & $<3.0$ & $<3.0$ & $<3.0$ & $<3.0$ \\
\hline$<3.0$ & $<3.0$ & $<3.0$ & $<3.0$ & $<3.0$ & $<3.0$ & $<3.0$ & $<3.0$ & $<3.0$ & $<3.0$ & $<3.0$ & $<3.0$ \\
\hline$<3.0$ & $<3.0$ & $<3.0$ & $<3.0$ & $<3.0$ & $<3.0$ & $<3.0$ & $<3.0$ & $<3.0$ & $<3.0$ & $<3.0$ & $<3.0$ \\
\hline$<3.0$ & $<3.0$ & $<3.0$ & $<3.0$ & $<3.0$ & $<3.0$ & $<3.0$ & $<3.0$ & $<3.0$ & $<3.0$ & $<3.0$ & $<3.0$ \\
\hline$<3.0$ & $<3.0$ & $<3.0$ & $<3.0$ & $<3.0$ & $<3.0$ & $<3.0$ & $<3.0$ & $<3.0$ & $<3.0$ & $<3.0$ & $<3.0$ \\
\hline$<3.0$ & $<3.0$ & $<3.0$ & $<3.0$ & $<3.0$ & $<3.0$ & $<3.0$ & $<3.0$ & $<3.0$ & $<3.0$ & $<3.0$ & $<3.0$ \\
\hline$<3.0$ & $<3.0$ & $<3.0$ & $<3.0$ & $<3.0$ & $<3.0$ & $<3.0$ & $<3.0$ & $<3.0$ & $<3.0$ & $<3.0$ & $<3.0$ \\
\hline$<3.0$ & $<3.0$ & $<3.0$ & $<3.0$ & $<3.0$ & $<3.0$ & $<3.0$ & $<3.0$ & $<3.0$ & $<3.0$ & $<3.0$ & $<3.0$ \\
\hline$<3.0$ & $<3.0$ & $<3.0$ & $<3.0$ & $<3.0$ & $<3.0$ & $<3.0$ & $<3.0$ & $<3.0$ & $<3.0$ & $<3.0$ & $<3.0$ \\
\hline$<3.0$ & $<3.0$ & $<3.0$ & $<3.0$ & $<3.0$ & $<3.0$ & $<3.0$ & $<3.0$ & $<3.0$ & $<3.0$ & $<3.0$ & $<3.0$ \\
\hline$<3.0$ & $<3.0$ & $<3.0$ & $<3.0$ & $<3.0$ & $<3.0$ & $<3.0$ & $<3.0$ & $<3.0$ & $<3.0$ & $<3.0$ & $<3.0$ \\
\hline$<3.0$ & $<3.0$ & $<3.0$ & $<3.0$ & $<3.0$ & $<3.0$ & $<3.0$ & $<3.0$ & $<3.0$ & $<3.0$ & $<3.0$ & $<3.0$ \\
\hline$<3.0$ & $<3.0$ & $<3.0$ & $<3.0$ & $<3.0$ & $<3.0$ & $<3.0$ & $<3.0$ & $<3.0$ & $<3.0$ & $<3.0$ & $<3.0$ \\
\hline$<3.0$ & $<3.0$ & $<3.0$ & $<3.0$ & $<3.0$ & $<3.0$ & $<3.0$ & $<3.0$ & $<3.0$ & $<3.0$ & $<3.0$ & $<3.0$ \\
\hline
\end{tabular}


Table 12. Concentrations of volatile organic compounds obtained from detailed samples-Continued

\begin{tabular}{|c|c|c|c|c|c|c|c|c|c|c|}
\hline $\begin{array}{l}\text { Station number } \\
\text { (other identifier) }\end{array}$ & Date & $\begin{array}{c}\text { Methyl- } \\
\text { ene } \\
\text { chloride } \\
(\mu g / L) \\
(34423) \\
\end{array}$ & $\begin{array}{c}\text { Chloro- } \\
\text { form } \\
(\mu \mathrm{g} / \mathrm{L}) \\
(32106)\end{array}$ & $\begin{array}{c}\text { 1,2- } \\
\text { Dibromo- } \\
\text { ethane } \\
(\mu g / L) \\
(77651)\end{array}$ & $\begin{array}{c}\text { Chloro- } \\
\text { ethane } \\
(\mu g / L) \\
(34311) \\
\end{array}$ & $\begin{array}{l}\text { 1,1-Di- } \\
\text { chloro- } \\
\text { ethane } \\
(\mu g / L) \\
(34496)\end{array}$ & $\begin{array}{l}\text { 1,2-Di- } \\
\text { chloro- } \\
\text { ethane } \\
(\mu g / L) \\
(32103)\end{array}$ & $\begin{array}{c}\text { Ethane, } \\
1,1,1,2- \\
\text { tetra- } \\
\text { chloro- } \\
(\mu g / L) \\
(77562) \\
\end{array}$ & $\begin{array}{c}\text { Ethane, } \\
1,1,2,2- \\
\text { tetra- } \\
\text { chloro- } \\
(\mu g / L) \\
(34516) \\
\end{array}$ & $\begin{array}{c}\text { 1,1,1-Tri- } \\
\text { chloro- } \\
\text { ethane } \\
(\mu g / L) \\
(34506)\end{array}$ \\
\hline \multirow{4}{*}{$\begin{array}{c}442150098120601 \\
\text { (James River at } \\
\text { Morningside) }\end{array}$} & $03-22-94$ & $<3.0$ & $<3.0$ & $<3.0$ & $<3.0$ & $<3.0$ & $<3.0$ & $<3.0$ & $<3.0$ & $<3.0$ \\
\hline & $05-02-94$ & $<3.0$ & $<3.0$ & $<3.0$ & $<3.0$ & $<3.0$ & $<3.0$ & $<3.0$ & $<3.0$ & $<3.0$ \\
\hline & $05-24-94$ & $<3.0$ & $<3.0$ & $<3.0$ & $<3.0$ & $<3.0$ & $<3.0$ & $<3.0$ & $<3.0$ & $<3.0$ \\
\hline & $06-28-94$ & $<3.0$ & $<3.0$ & $<3.0$ & $<3.0$ & $<3.0$ & $<3.0$ & $<3.0$ & $<3.0$ & $<3.0$ \\
\hline \multirow{4}{*}{$\begin{array}{l}442150098120602 \\
\text { (Huron Water } \\
\text { Treatment Plant } \\
\text { effluent) }\end{array}$} & $03-22-94$ & $<3.0$ & 25 & $<3.0$ & $<3.0$ & $<3.0$ & $<3.0$ & $<3.0$ & $<3.0$ & $<3.0$ \\
\hline & $05-02-94$ & $<3.0$ & 21 & $<3.0$ & $<3.0$ & $<3.0$ & $<3.0$ & $<3.0$ & $<3.0$ & $<3.0$ \\
\hline & $05-24-94$ & $<3.0$ & 40 & $<3.0$ & $<3.0$ & $<3.0$ & $<3.0$ & $<3.0$ & $<3.0$ & $<3.0$ \\
\hline & $06-28-94$ & $<3.0$ & 63 & $<3.0$ & $<3.0$ & $<3.0$ & $<3.0$ & $<3.0$ & $<3.0$ & $<3.0$ \\
\hline \multirow{4}{*}{$\begin{array}{c}42150098174401 \\
(\mathrm{CO}-05-90)\end{array}$} & $12-14-93$ & $<3.0$ & $<3.0$ & $<3.0$ & $<3.0$ & $<3.0$ & $<3.0$ & $<3.0$ & $<3.0$ & $<3.0$ \\
\hline & $03-22-94$ & $<3.0$ & $<3.0$ & $<3.0$ & $<3.0$ & $<3.0$ & $<3.0$ & $<3.0$ & $<3.0$ & $<3.0$ \\
\hline & $05-24-94$ & $<3.0$ & $<3.0$ & $<3.0$ & $<3.0$ & $<3.0$ & $<3.0$ & $<3.0$ & $<3.0$ & $<3.0$ \\
\hline & $06-28-94$ & $<3.0$ & $<3.0$ & $<3.0$ & $<3.0$ & $<3.0$ & $<3.0$ & $<3.0$ & $<3.0$ & $<3.0$ \\
\hline \multirow{4}{*}{$\begin{array}{l}442111098173801 \\
(\mathrm{CO}-18-90)\end{array}$} & $12-14-93$ & $<3.0$ & $<3.0$ & $<3.0$ & $<3.0$ & $<3.0$ & $<3.0$ & $<3.0$ & $<3.0$ & $<3.0$ \\
\hline & $03-22-94$ & $<3.0$ & $<3.0$ & $<3.0$ & $<3.0$ & $<3.0$ & $<3.0$ & $<3.0$ & $<3.0$ & $<3.0$ \\
\hline & $05-24-94$ & $<3.0$ & $<3.0$ & $<3.0$ & $<3.0$ & $<3.0$ & $<3.0$ & $<3.0$ & $<3.0$ & $<3.0$ \\
\hline & $06-28-94$ & $<3.0$ & $<3.0$ & $<3.0$ & $<3.0$ & $<3.0$ & $<3.0$ & $<3.0$ & $<3.0$ & $<3.0$ \\
\hline
\end{tabular}




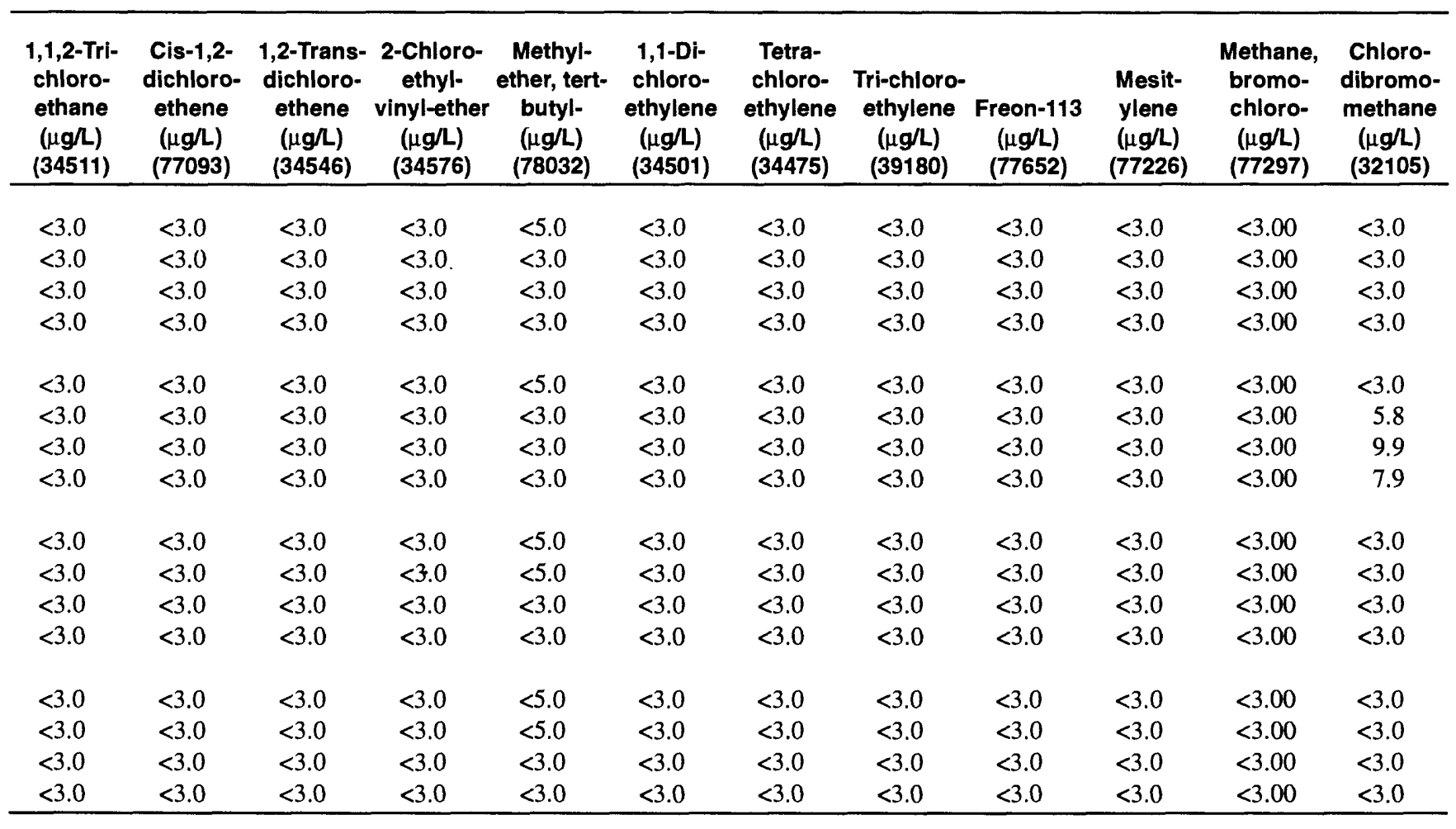


Table 12. Concentrations of volatile organic compounds obtained from detailed samples-Continued

\begin{tabular}{|c|c|c|c|c|c|c|c|c|c|c|}
\hline $\begin{array}{l}\text { Station number } \\
\text { (other identifier) }\end{array}$ & Date & $\begin{array}{c}\text { Dibromo- } \\
\text { methane } \\
(\mu \mathrm{g} / \mathrm{L}) \\
(30217) \\
\end{array}$ & $\begin{array}{c}\text { Dichloro- } \\
\text { bromo- } \\
\text { methane } \\
(\mu \mathrm{g} / \mathrm{L}) \\
(32101) \\
\end{array}$ & $\begin{array}{c}\text { Dichloro- } \\
\text { difluoro- } \\
\text { methane } \\
(\mu g / L) \\
(34668) \\
\end{array}$ & $\begin{array}{c}\text { Trichloro- } \\
\text { fluoro- } \\
\text { methane } \\
(\mu \mathrm{g} / \mathrm{L}) \\
(34488) \\
\end{array}$ & $\begin{array}{c}\text { Naphth- } \\
\text { alene } \\
(\mu g / L) \\
(34696) \\
\end{array}$ & $\begin{array}{c}\text { Dibromo- } \\
\text { chloro- } \\
\text { propane } \\
\text { ( } \mu \mathrm{g} / \mathrm{L}) \\
(82625) \\
\end{array}$ & $\begin{array}{c}\text { T,2-Di- } \\
\text { chloro- } \\
\text { propane } \\
(\mu g / L) \\
(34541) \\
\end{array}$ & $\begin{array}{c}\text { T,3-Di- } \\
\text { chloro- } \\
\text { propane } \\
(\mu \mathrm{g} / \mathrm{L}) \\
(77173) \\
\end{array}$ & $\begin{array}{c}\text { 2,2-Di- } \\
\text { chloro- } \\
\text { propane } \\
(\mu g / L) \\
(77170) \\
\end{array}$ \\
\hline \multirow{4}{*}{$\begin{array}{c}442150098120601 \\
\text { (James River at } \\
\text { Morningside) }\end{array}$} & $03-22-94$ & $<3.0$ & $<3.0$ & $<3.0$ & $<3.0$ & $<3.0$ & $<3.0$ & $<3.0$ & $<3.0$ & $<3.0$ \\
\hline & $05-02-94$ & $<3.0$ & $<3.0$ & $<3.0$ & $<3.0$ & $<3.0$ & $<3.0$ & $<3.0$ & $<3.0$ & $<3.0$ \\
\hline & $05-24-94$ & $<3.0$ & $<3.0$ & $<3.0$ & $<3.0$ & $<3.0$ & $<3.0$ & $<3.0$ & $<3.0$ & $<3.0$ \\
\hline & $06-28-94$ & $<3.0$ & $<3.0$ & $<3.0$ & $<3.0$ & $<3.0$ & $<3.0$ & $<3.0$ & $<3.0$ & $<3.0$ \\
\hline \multirow{4}{*}{$\begin{array}{l}442150098120602 \\
\text { (Huron Water } \\
\text { Treatment Plant } \\
\text { effluent) }\end{array}$} & $03-22-94$ & $<3.0$ & 8.5 & $<3.0$ & $<3.0$ & $<3.0$ & $<3.0$ & $<3.0$ & $<3.0$ & $<3.0$ \\
\hline & $05-02-94$ & $<3.0$ & 13 & $<3.0$ & $<3.0$ & $<3.0$ & $<3.0$ & $<3.0$ & $<3.0$ & $<3.0$ \\
\hline & $05-24-94$ & $<3.0$ & 23 & $<3.0$ & $<3.0$ & $<3.0$ & $<3.0$ & $<3.0$ & $<3.0$ & $<3.0$ \\
\hline & $06-28-94$ & $<3.0$ & 26 & $<3.0$ & $<3.0$ & $<3.0$ & $<3.0$ & $<3.0$ & $<3.0$ & $<3.0$ \\
\hline \multirow{4}{*}{$\begin{array}{l}42150098174401 \\
(\mathrm{CO}-05-90)\end{array}$} & $12-14-93$ & $<3.0$ & $<3.0$ & $<3.0$ & $<3.0$ & $<3.0$ & $<3.0$ & $<3.0$ & $<3.0$ & $<3.0$ \\
\hline & $03-22-94$ & $<3.0$ & $<3.0$ & $<3.0$ & $<3.0$ & $<3.0$ & $<3.0$ & $<3.0$ & $<3.0$ & $<3.0$ \\
\hline & $05-24-94$ & $<3.0$ & $<3.0$ & $<3.0$ & $<3.0$ & $<3.0$ & $<3.0$ & $<3.0$ & $<3.0$ & $<3.0$ \\
\hline & $06-28-94$ & $<3.0$ & $<3.0$ & $<3.0$ & $<3.0$ & $<3.0$ & $<3.0$ & $<3.0$ & $<3.0$ & $<3.0$ \\
\hline \multirow{4}{*}{$\begin{array}{l}442111098173801 \\
(\mathrm{CO}-18-90)\end{array}$} & $12-14-93$ & $<3.0$ & $<3.0$ & $<3.0$ & $<3.0$ & $<3.0$ & $<3.0$ & $<3.0$ & $<3.0$ & $<3.0$ \\
\hline & $03-22-94$ & $<3.0$ & $<3.0$ & $<3.0$ & $<3.0$ & $<3.0$ & $<3.0$ & $<3.0$ & $<3.0$ & $<3.0$ \\
\hline & $05-24-94$ & $<3.0$ & $<3.0$ & $<3.0$ & $<3.0$ & $<3.0$ & $<3.0$ & $<3.0$ & $<3.0$ & $<3.0$ \\
\hline & $06-28-94$ & $<3.0$ & $<3.0$ & $<3.0$ & $<3.0$ & $<3.0$ & $<3.0$ & $<3.0$ & $<3.0$ & $<3.0$ \\
\hline
\end{tabular}




\begin{tabular}{|c|c|c|c|c|c|c|c|c|c|c|c|}
\hline $\begin{array}{c}, 2,3-T r i- \\
\text { chloro- } \\
\text { propane } \\
(\mu \mathrm{g} / \mathrm{L}) \\
(\mathbf{7 7 4 4 3 )}\end{array}$ & $\begin{array}{c}\text { T,1-Di- } \\
\text { chloro- } \\
\text { propene } \\
(\mu g / L) \\
(77168)\end{array}$ & $\begin{array}{l}\text { Cis-1,3- } \\
\text { dichloro- } \\
\text { propene } \\
(\mu \mathrm{g} / \mathrm{L}) \\
(\mathbf{3 4 7 0 4 )}\end{array}$ & $\begin{array}{l}\text { Trans-1,3- } \\
\text { dichloro- } \\
\text { propene } \\
(\mu g / L) \\
(34699)\end{array}$ & $\begin{array}{c}\text { Pseudo- } \\
\text { cumene } \\
(\mu g / L) \\
(77222)\end{array}$ & $\begin{array}{c}\text { Styrene } \\
(\mu g / L) \\
(77128)\end{array}$ & $\begin{array}{c}\text { Toluene } \\
(\mu \mathrm{g} / \mathrm{L}) \\
(34010)\end{array}$ & $\begin{array}{c}\text { O-chloro- } \\
\text { toluene } \\
(\mu g / L) \\
(77275)\end{array}$ & $\begin{array}{c}\text { Toluene, } \\
\text { p-chlor } \\
(\mu g / L) \\
(77277)\end{array}$ & $\begin{array}{c}\text { P-iso- } \\
\text { propyl- } \\
\text { toluene } \\
(\mu g / L) \\
(77356)\end{array}$ & $\begin{array}{c}\text { Vinyl- } \\
\text { chloride } \\
(\mu g / L) \\
(39175)\end{array}$ & $\begin{array}{c}\text { Xylene } \\
(\mu g / L) \\
(81551)\end{array}$ \\
\hline$<3.0$ & $<3.0$ & $<3.0$ & $<3.0$ & $<3.0$ & $<3.0$ & $<3.0$ & $<3.0$ & $<3.0$ & $<3.0$ & $<1.0$ & $<3.0$ \\
\hline$<3.0$ & $<3.0$ & $<3.0$ & $<3.0$ & $<3.0$ & $<3.0$ & $<3.0$ & $<3.0$ & $<3.0$ & $<3.0$ & $<1.0$ & $<3.0$ \\
\hline$<3.0$ & $<3.0$ & $<3.0$ & $<3.0$ & $<3.0$ & $<3.0$ & $<3.0$ & $<3.0$ & $<3.0$ & $<3.0$ & $<1.0$ & $<3.0$ \\
\hline$<3.0$ & $<3.0$ & $<3.0$ & $<3.0$ & $<3.0$ & $<3.0$ & $<3.0$ & $<3.0$ & $<3.0$ & $<3.0$ & $<1.0$ & $<3.0$ \\
\hline$<3.0$ & $<3.0$ & $<3.0$ & $<3.0$ & $<3.0$ & $<3.0$ & $<3.0$ & $<3.0$ & $<3.0$ & $<3.0$ & $<1.0$ & 3.5 \\
\hline$<3.0$ & $<3.0$ & $<3.0$ & $<3.0$ & $<3.0$ & $<3.0$ & $<3.0$ & $<3.0$ & $<3.0$ & $<3.0$ & $<1.0$ & $<3.0$ \\
\hline$<3.0$ & $<3.0$ & $<3.0$ & $<3.0$ & $<3.0$ & $<3.0$ & $<3.0$ & $<3.0$ & $<3.0$ & $<3.0$ & $<1.0$ & $<3.0$ \\
\hline$<3.0$ & $<3.0$ & $<3.0$ & $<3.0$ & $<3.0$ & $<3.0$ & $<3.0$ & $<3.0$ & $<3.0$ & $<3.0$ & $<1.0$ & $<3.0$ \\
\hline$<3.0$ & $<3.0$ & $<3.0$ & $<3.0$ & $<3.0$ & $<3.0$ & $<3.0$ & $<3.0$ & $<3.0$ & $<3.0$ & $<1.0$ & $<3.0$ \\
\hline$<3.0$ & $<3.0$ & $<3.0$ & $<3.0$ & $<3.0$ & $<3.0$ & $<3.0$ & $<3.0$ & $<3.0$ & $<3.0$ & $<1.0$ & $<3.0$ \\
\hline$<3.0$ & $<3.0$ & $<3.0$ & $<3.0$ & $<3.0$ & $<3.0$ & $<3.0$ & $<3.0$ & $<3.0$ & $<3.0$ & $<1.0$ & $<3.0$ \\
\hline$<3.0$ & $<3.0$ & $<3.0$ & $<3.0$ & $<3.0$ & $<3.0$ & $<3.0$ & $<3.0$ & $<3.0$ & $<3.0$ & $<1.0$ & $<3.0$ \\
\hline$<3.0$ & $<3.0$ & $<3.0$ & $<3.0$ & $<3.0$ & $<3.0$ & $<3.0$ & $<3.0$ & $<3.0$ & $<3.0$ & $<1.0$ & $<3.0$ \\
\hline$<3.0$ & $<3.0$ & $<3.0$ & $<3.0$ & $<3.0$ & $<3.0$ & $<3.0$ & $<3.0$ & $<3.0$ & $<3.0$ & $<1.0$ & $<3.0$ \\
\hline$<3.0$ & $<3.0$ & $<3.0$ & $<3.0$ & $<3.0$ & $<3.0$ & $<3.0$ & $<3.0$ & $<3.0$ & $<3.0$ & $<1.0$ & $<3.0$ \\
\hline$<3.0$ & $<3.0$ & $<3.0$ & $<3.0$ & $<3.0$ & $<3.0$ & $<3.0$ & $<3.0$ & $<3.0$ & $<3.0$ & $<1.0$ & $<3.0$ \\
\hline
\end{tabular}


Table 13. Water-quality data obtained from plume-monitoring samples

$[\mu \mathrm{S} / \mathrm{cm}$, microsiemens per centimeter; $\mathrm{mg} / \mathrm{L}$, milligrams per liter; $\mathrm{mV}$, millivolt; $\mathrm{mL}$, milliliter; $\mu \mathrm{g} / \mathrm{L}$, micrograms per liter; FET, fixed end point titration; IT, incremental titration; --, no data]

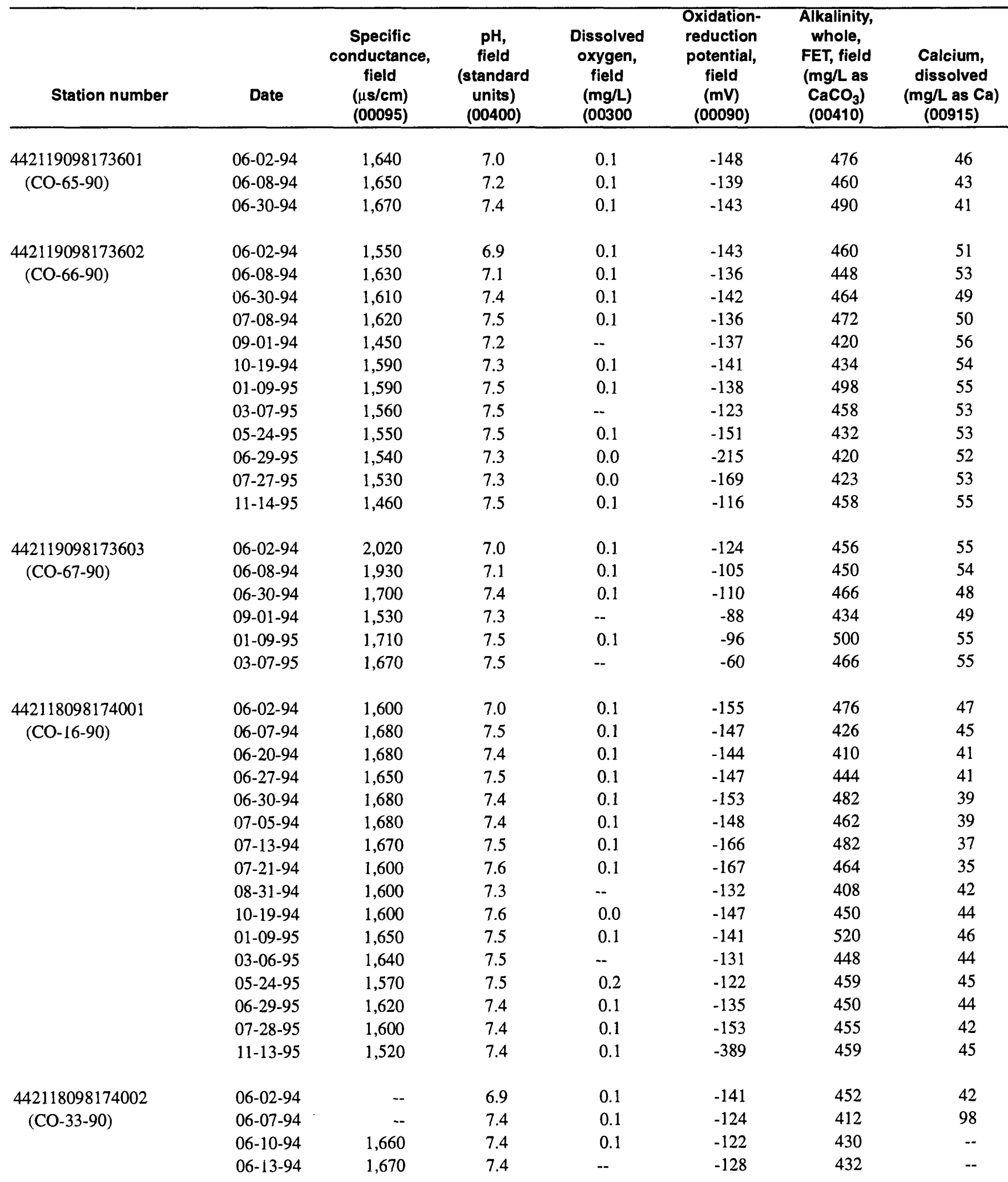




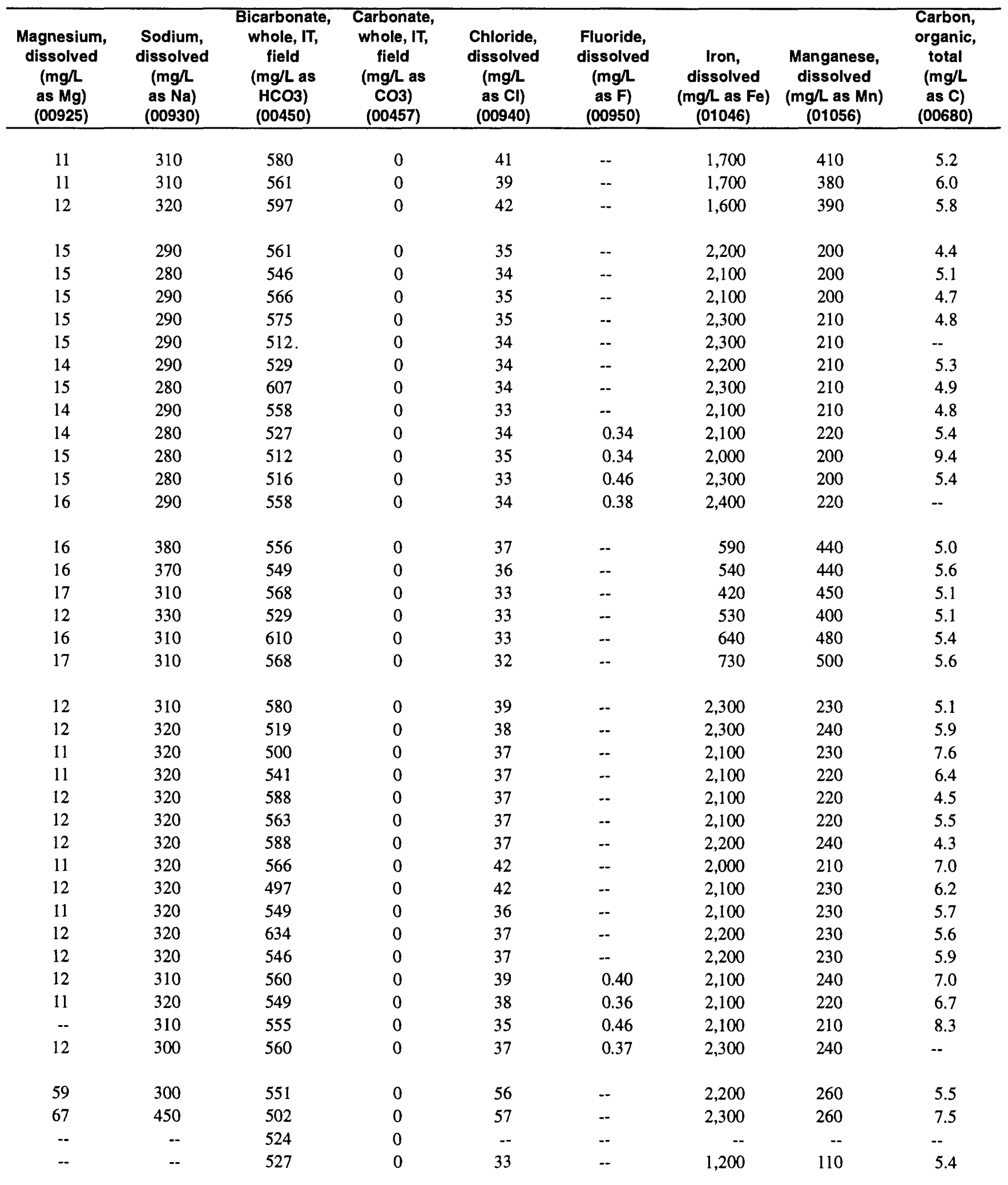


Table 13. Water-quality data obtained from plume-monitoring samples-Continued

\begin{tabular}{|c|c|c|c|c|c|c|c|}
\hline Station number & Date & $\begin{array}{c}\text { Specific } \\
\text { conductance, } \\
\text { field } \\
(\mu \mathrm{s} / \mathrm{cm}) \\
(00095)\end{array}$ & $\begin{array}{c}\text { pH, } \\
\text { field } \\
\text { (standard } \\
\text { units) } \\
(00400) \\
\end{array}$ & $\begin{array}{c}\text { Dissolved } \\
\text { oxygen, } \\
\text { field } \\
(\mathrm{mg} / \mathrm{L}) \\
(00300 \\
\end{array}$ & $\begin{array}{l}\text { Oxidation- } \\
\text { reduction } \\
\text { potential, } \\
\text { field } \\
(\mathrm{mV}) \\
(00090) \\
\end{array}$ & $\begin{array}{l}\text { Alkalinity, } \\
\text { whole, } \\
\text { FET, field } \\
\text { (mg/L as } \\
\left.\mathrm{CaCO}_{3}\right) \\
(00410) \\
\end{array}$ & $\begin{array}{c}\text { Calcium, } \\
\text { dissolved } \\
(\mathrm{mg} / \mathrm{L} \text { as } \mathrm{Ca}) \\
(00915)\end{array}$ \\
\hline 442118098174002 & $06-23-94$ & 1,660 & 7.5 & 0.1 & -130 & 432 & -- \\
\hline \multirow[t]{24}{*}{ (CO-33-90)-Cont. } & $06-30-94$ & 1,670 & 7.4 & 0.1 & -143 & 472 & 37 \\
\hline & $07-05-94$ & -- & 7.3 & 0.1 & -127 & 428 & 99 \\
\hline & $07-08-94$ & 1,850 & 7.5 & 0.1 & -143 & 464 & 44 \\
\hline & $07-15-94$ & 1,890 & 7.5 & 0.1 & -147 & 466 & 46 \\
\hline & $07-18-94$ & 1,900 & 7.5 & 0.1 & -153 & 478 & 46 \\
\hline & $07-21-94$ & 1,930 & 7.6 & 0.1 & -152 & 460 & 46 \\
\hline & $07-25-94$ & 1,930 & 7.6 & 0.1 & -170 & 452 & 46 \\
\hline & $08-31-94$ & 1,960 & 7.3 & -- & -115 & 400 & 48 \\
\hline & $10-19-94$ & 2,450 & 7.6 & 0.1 & -126 & 418 & 81 \\
\hline & $01-09-95$ & 2,230 & 7.5 & 0.1 & -131 & 500 & 61 \\
\hline & $03-06-95$ & 2,480 & 7.5 & -- & -108 & 448 & 75 \\
\hline & $05-24-95$ & 2,630 & 7.5 & 0.1 & -92 & 432 & 91 \\
\hline & $06-16-95$ & 2,580 & 7.2 & 0.1 & -126 & 412 & 72 \\
\hline & $06-21-95$ & 2,110 & 7.3 & 0.0 & -158 & 450 & 58 \\
\hline & $06-29-95$ & 2,150 & 7.3 & 0.1 & -141 & 454 & 62 \\
\hline & $07-10-95$ & 2,000 & 7.3 & 0.1 & -171 & 427 & 57 \\
\hline & $07-13-95$ & 1,980 & 7.2 & 0.0 & -135 & 432 & 57 \\
\hline & $07-20-95$ & 1,950 & 7.4 & 0.1 & -108 & 420 & 54 \\
\hline & $07-28-95$ & 2,660 & 7.4 & 0.0 & -139 & 439 & 90 \\
\hline & $08-03-95$ & 1,800 & 7.4 & 0.0 & -149 & 428 & 46 \\
\hline & $08-10-95$ & 2,040 & 7.4 & 0.0 & -148 & 416 & 55 \\
\hline & $08-17-95$ & 1,940 & 7.5 & 0.1 & -130 & 424 & 53 \\
\hline & 09-06-95 & 1,910 & 7.5 & 0.0 & -143 & 350 & 54 \\
\hline & $11-13-95$ & 2,470 & 7.3 & 0.1 & -387 & 450 & 87 \\
\hline 442118098174003 & $06-02-94$ & -- & 6.9 & 0.1 & -87 & 472 & 90 \\
\hline \multirow[t]{20}{*}{$(\mathrm{CO}-34-90)$} & $06-07-94$ & -- & 7.4 & 0.1 & -81 & 414 & 82 \\
\hline & $06-10-94$ & 1,970 & 7.4 & 0.1 & -81 & 430 & -- \\
\hline & $06-13-94$ & 1,940 & 7.4 & - & -86 & 436 & -- \\
\hline & $06-16-94$ & 1,860 & 7.4 & 0.1 & -83 & 430 & 32 \\
\hline & $06-20-94$ & 1,950 & 7.4 & 0.1 & -87 & 422 & 36 \\
\hline & $06-23-94$ & 1,940 & 7.4 & 0.1 & -88 & 444 & -- \\
\hline & $06-27-94$ & 1,890 & 7.4 & 0.1 & -91 & 422 & 36 \\
\hline & $06-30-94$ & 1,920 & 7.4 & 0.1 & -96 & 468 & 35 \\
\hline & $07-05-94$ & -- & 7.3 & 0.1 & -83 & 468 & 82 \\
\hline & $07-08-94$ & 1,890 & 7.5 & 0.1 & -117 & 478 & 34 \\
\hline & $07-13-94$ & 1,920 & 7.5 & 0.1 & -114 & 470 & 36 \\
\hline & $07-15-94$ & 1,920 & 7.5 & 0.1 & -116 & 460 & 35 \\
\hline & $07-18-94$ & 1,850 & 7.5 & 0.1 & -125 & 480 & 36 \\
\hline & $07-21-94$ & 1,910 & 7.6 & 0.1 & -125 & 490 & 38 \\
\hline & $07-25-94$ & 1,940 & 7.6 & 0.1 & -149 & 486 & 40 \\
\hline & $08-31-94$ & 3,160 & 7.3 & -- & -79 & 442 & 82 \\
\hline & $10-19-94$ & 3,220 & 7.6 & 0.1 & -101 & 446 & 85 \\
\hline & $01-09-95$ & -- & 7.4 & 0.1 & -98 & 520 & 92 \\
\hline & $03-06-95$ & 2,950 & 7.5 & -- & -99 & 466 & 73 \\
\hline & $05-24-95$ & 3,900 & 7.5 & 0.2 & -125 & 444 & 98 \\
\hline
\end{tabular}




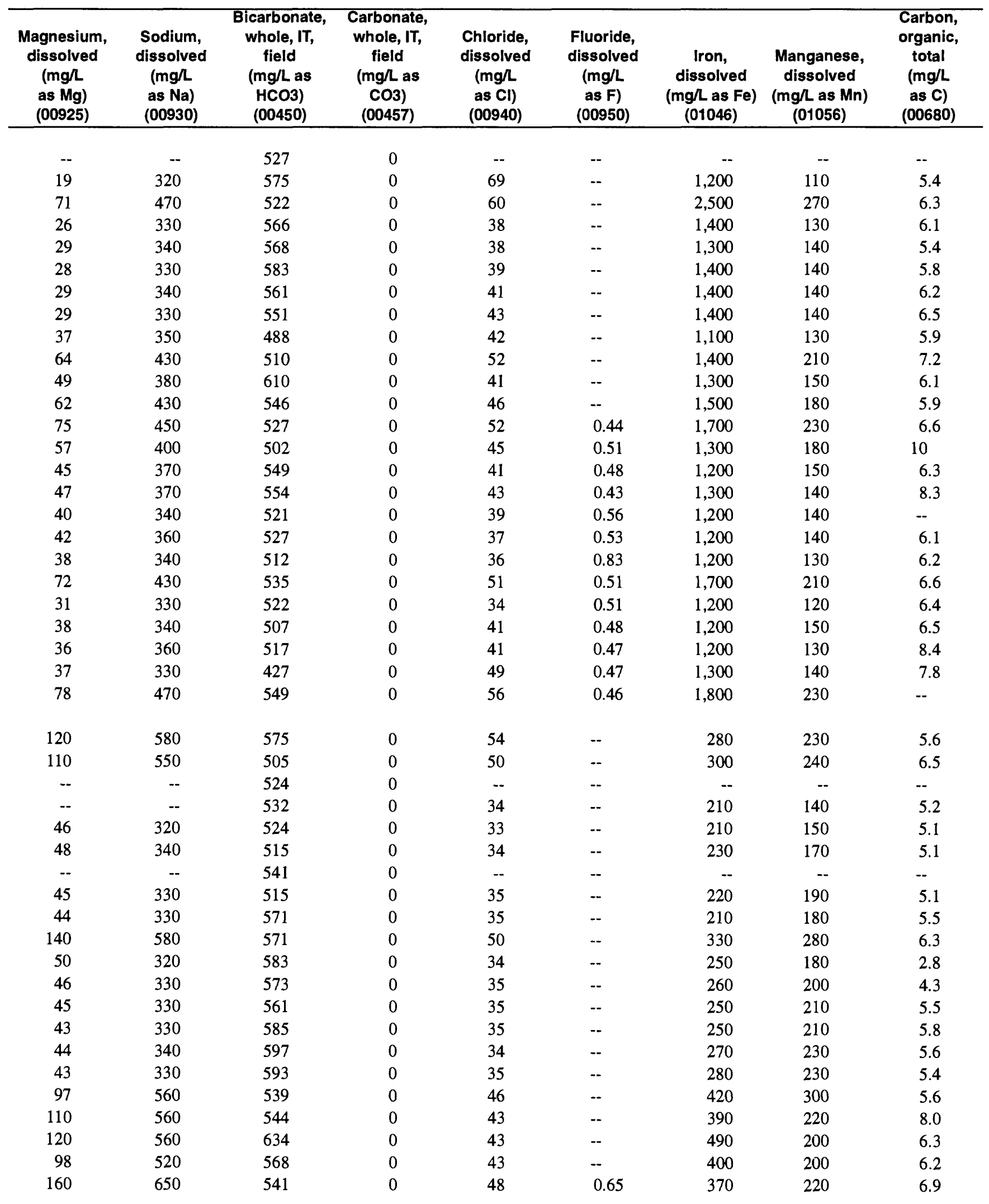


Table 13. Water-quality data obtained from plume-monitoring samples-Continued

\begin{tabular}{|c|c|c|c|c|c|c|c|}
\hline Station number & Date & $\begin{array}{c}\text { Specific } \\
\text { conductance, } \\
\text { field } \\
(\mu \mathrm{s} / \mathrm{cm}) \\
(00095) \\
\end{array}$ & $\begin{array}{c}\text { pH, } \\
\text { field } \\
\text { (standard } \\
\text { units) } \\
(00400) \\
\end{array}$ & $\begin{array}{c}\text { Dissolved } \\
\text { oxygen, } \\
\text { field } \\
\text { (mg/L) } \\
(00300 \\
\end{array}$ & $\begin{array}{l}\text { Oxidation- } \\
\text { reduction } \\
\text { potential, } \\
\text { field } \\
(\mathrm{mV}) \\
(00090) \\
\end{array}$ & $\begin{array}{l}\text { Alkalinity, } \\
\text { whole, } \\
\text { FET, field } \\
\text { (mg/L as } \\
\left.\mathrm{CaCO}_{3}\right) \\
(00410) \\
\end{array}$ & $\begin{array}{c}\text { Calcium, } \\
\text { dissolved } \\
\text { (mg/L as Ca) } \\
\text { (00915) } \\
\end{array}$ \\
\hline \multirow{3}{*}{$\begin{array}{l}442118098174003 \\
\text { (CO-34-90)—Cont. }\end{array}$} & 06-29-95 & 2,270 & 7.4 & 0.1 & -114 & 466 & 46 \\
\hline & $07-28-95$ & 3,180 & 7.4 & 0.0 & -92 & 442 & 77 \\
\hline & $11-13-95$ & 3,410 & 7.3 & 0.1 & -217 & 456 & 110 \\
\hline \multirow{32}{*}{$\begin{array}{l}442117098173603 \\
(\mathrm{CO}-47-90)\end{array}$} & 06-02-94 & 1,580 & 6.9 & 0.1 & -136 & 456 & 52 \\
\hline & $06-07-94$ & 1,620 & 7.2 & 0.1 & -133 & 418 & 51 \\
\hline & $08-31-94$ & 1,440 & 7.2 & -- & -125 & 410 & 52 \\
\hline & $10-19-94$ & 1,600 & 7.6 & 0.1 & -141 & 442 & 52 \\
\hline & $01-09-95$ & 1,610 & 7.5 & 0.0 & -131 & 508 & 60 \\
\hline & $03-07-95$ & 1,570 & 7.5 & -- & -124 & 468 & 51 \\
\hline & $05-24-95$ & 1,540 & 7.3 & 0.4 & -126 & 439 & 52 \\
\hline & $06-21-95$ & 1,570 & 7.3 & 0.0 & -170 & 479 & 51 \\
\hline & $06-26-95$ & 1,540 & 7.4 & 0.0 & -257 & 436 & 51 \\
\hline & $06-30-95$ & 1,550 & 7.3 & 0.0 & -201 & 454 & 50 \\
\hline & $07-05-95$ & 1,550 & 7.1 & 0.1 & -129 & 449 & 51 \\
\hline & $07-10-95$ & 1,540 & 7.3 & 0.1 & -156 & 422 & 51 \\
\hline & $07-13-95$ & 1,540 & 7.1 & 0.0 & -139 & 449 & 51 \\
\hline & $07-20-95$ & 1,550 & 7.4 & 0.1 & -143 & 433 & 52 \\
\hline & $07-28-95$ & 1,540 & 7.4 & 0.0 & -154 & 440 & 51 \\
\hline & 08-03-95 & 1,560 & 7.4 & 0.0 & -156 & 441 & 50 \\
\hline & $08-10-95$ & 1,570 & 7.5 & 0.0 & -129 & 426 & 52 \\
\hline & $08-17-95$ & 1,580 & 7.4 & 0.0 & -161 & 447 & 51 \\
\hline & 08-30-95 & 1,570 & 7.5 & 0.0 & -128 & 442 & 51 \\
\hline & $09-06-95$ & 1,570 & 7.5 & 0.0 & -150 & 406 & 51 \\
\hline & $09-11-95$ & 1,550 & 7.5 & 0.1 & -124 & 413 & 50 \\
\hline & 09-19-95 & 1,550 & 7.5 & 0.1 & -124 & 413 & 50 \\
\hline & $09-26-95$ & 1,520 & 7.5 & 0.1 & -141 & 458 & 49 \\
\hline & $09-29-95$ & 1,520 & 7.4 & 0.1 & -130 & 448 & 52 \\
\hline & $10-03-95$ & 1,510 & 7.4 & 0.0 & -129 & 442 & 52 \\
\hline & $10-06-95$ & 1,520 & 7.5 & 0.0 & -146 & 468 & 50 \\
\hline & $10-09-95$ & 1,500 & 7.4 & 0.1 & -260 & 452 & 50 \\
\hline & $10-13-95$ & 1,500 & 7.4 & 0.1 & -114 & 448 & 51 \\
\hline & $10-16-95$ & 1,510 & 7.4 & -- & -- & 432 & 51 \\
\hline & $10-20-95$ & 1,460 & 7.4 & 0.1 & -132 & 441 & 52 \\
\hline & $11-06-95$ & 1,420 & 7.4 & -- & -358 & 432 & 51 \\
\hline & $11-14-95$ & 1,470 & 7.5 & 0.1 & -101 & 454 & 51 \\
\hline \multirow{11}{*}{$\begin{array}{l}442117098173604 \\
(\mathrm{CO}-48-90)\end{array}$} & 06-02-94 & 1,800 & 6.9 & 0.1 & -94 & 452 & 73 \\
\hline & $06-07-94$ & 1,760 & 7.1 & 0.1 & -91 & 414 & 68 \\
\hline & $07-05-94$ & 1,640 & 7.4 & 0.1 & -103 & 444 & 53 \\
\hline & 07-08-94 & 1,510 & 7.5 & 0.1 & -102 & 466 & 54 \\
\hline & 07-13-94 & 1,630 & 7.5 & 0.1 & -127 & 464 & 51 \\
\hline & $07-21-94$ & 1,660 & 7.4 & 0.1 & -133 & 452 & 57 \\
\hline & $07-25-94$ & 1,630 & 7.6 & 0.1 & -144 & 476 & 52 \\
\hline & $08-31-94$ & 1,620 & 7.3 & -- & -15 & 418 & 60 \\
\hline & $10-19-94$ & 1,640 & 7.5 & 0.0 & -108 & 436 & 66 \\
\hline & 01-09-95 & 1,790 & 7.5 & 0.1 & -85 & 502 & 73 \\
\hline & 03-07-95 & 1,640 & 7.5 & -- & -105 & 462 & 63 \\
\hline
\end{tabular}




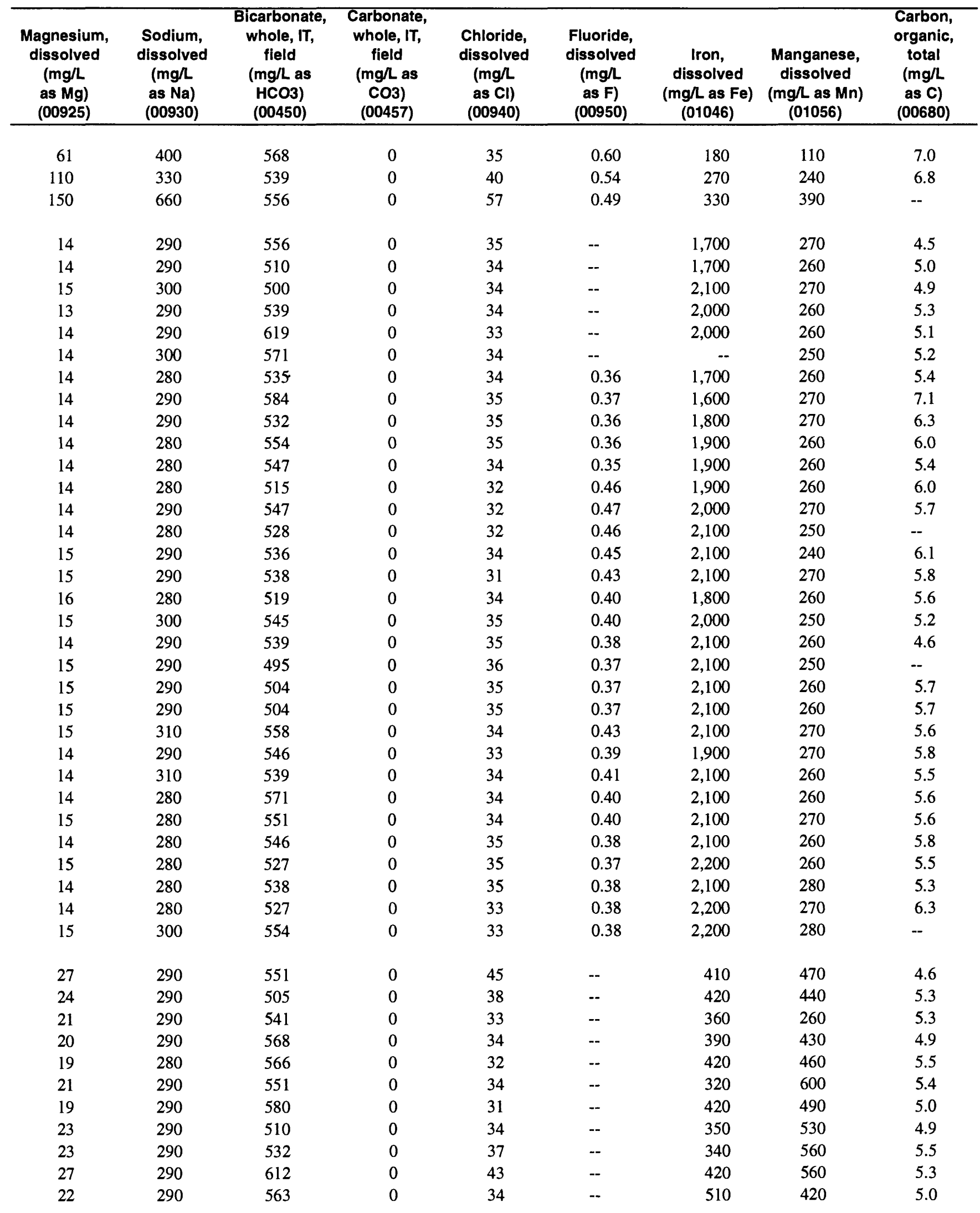


Table 13. Water-quality data obtained from plume-monitoring samples-Continued

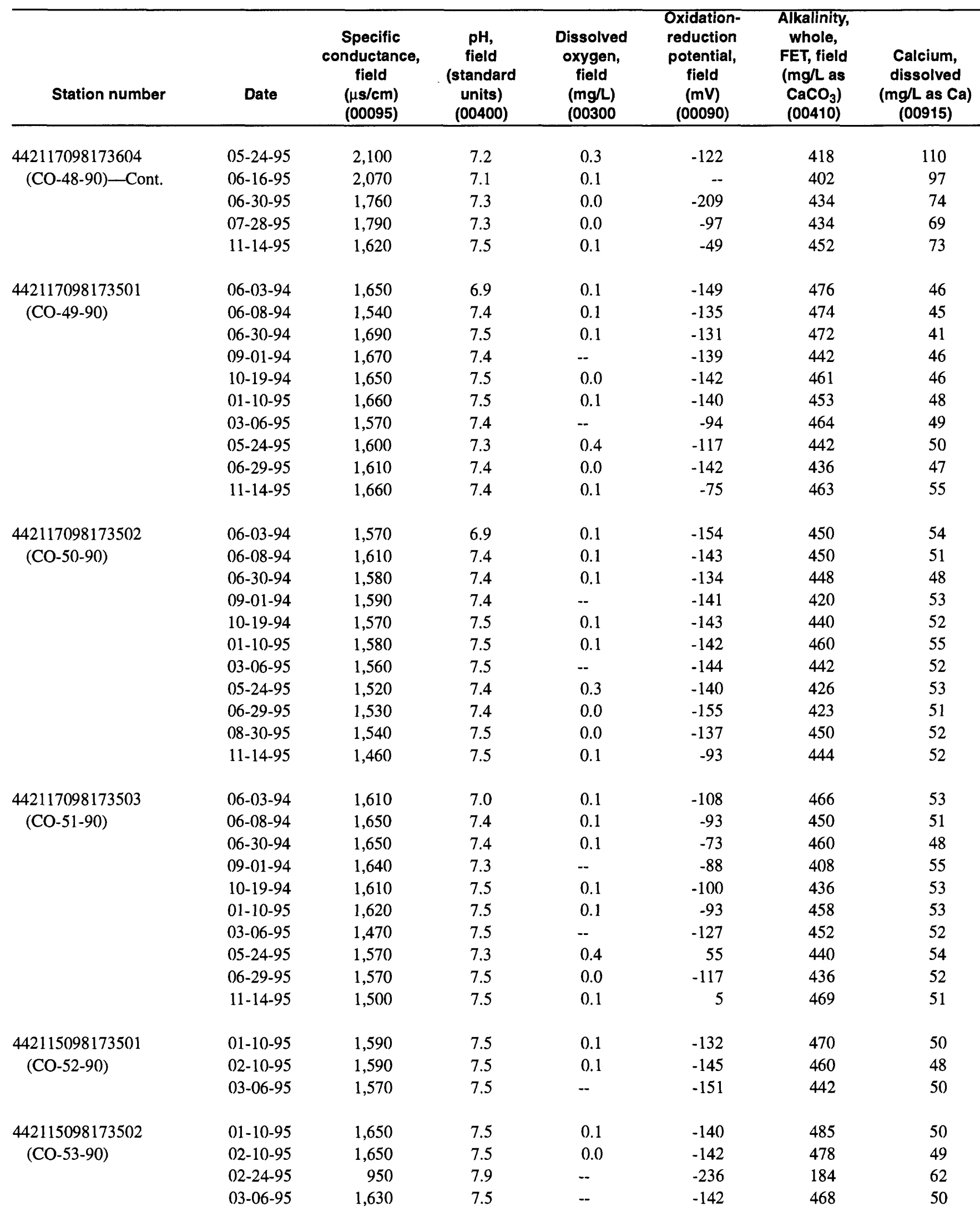




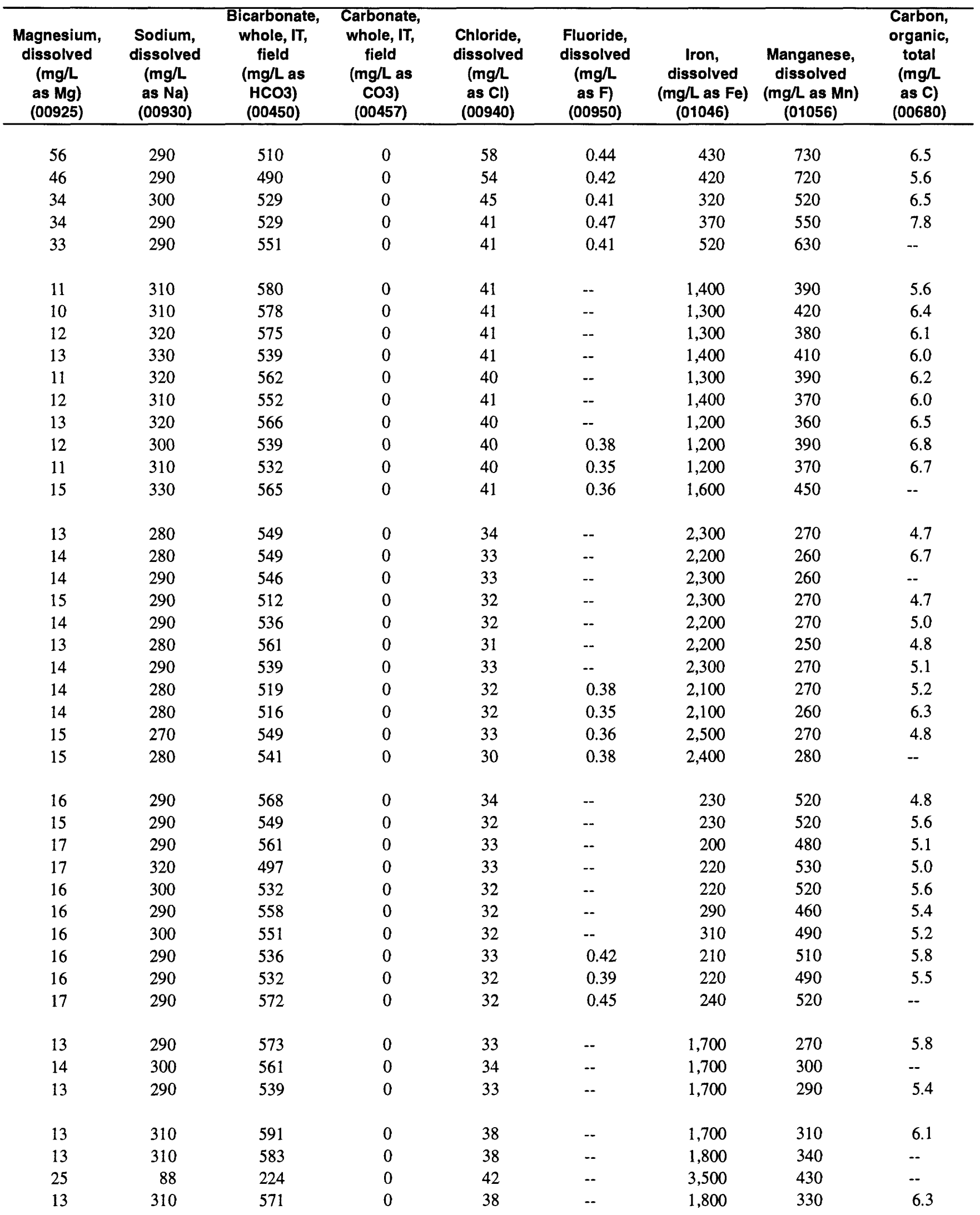


Table 13. Water-quality data obtained from plume-monitoring samples-Continued

\begin{tabular}{|c|c|c|c|c|c|c|c|}
\hline Station number & Date & $\begin{array}{c}\text { Specific } \\
\text { conductance, } \\
\text { field } \\
(\mu s / \mathrm{cm}) \\
(00095) \\
\end{array}$ & $\begin{array}{c}\text { pH, } \\
\text { field } \\
\text { (standard } \\
\text { units) } \\
(00400) \\
\end{array}$ & $\begin{array}{c}\text { Dissolved } \\
\text { oxygen, } \\
\text { field } \\
\text { (mg/L) } \\
(00300 \\
\end{array}$ & $\begin{array}{l}\text { Oxidation- } \\
\text { reduction } \\
\text { potential, } \\
\text { field } \\
(\mathrm{mV}) \\
(00090) \\
\end{array}$ & $\begin{array}{c}\text { Alkalinity, } \\
\text { whole, } \\
\text { FET, field } \\
\text { (mg/L as } \\
\left.\mathrm{CaCO}_{3}\right) \\
(00410) \\
\end{array}$ & $\begin{array}{c}\text { Calcium, } \\
\text { dissolved } \\
(\mathrm{mg} / \mathrm{L} \text { as Ca) } \\
(00915)\end{array}$ \\
\hline \multirow{3}{*}{$\begin{array}{l}442115098173503 \\
(C O-54-90)\end{array}$} & $01-10-95$ & 1,610 & 7.5 & 0.1 & -79 & 456 & 60 \\
\hline & $02-10-95$ & 1,610 & 7.4 & 0.1 & -74 & 450 & 58 \\
\hline & $03-06-95$ & 1,780 & 7.3 & -- & -41 & 458 & 90 \\
\hline \multirow{40}{*}{$\begin{array}{l}442117098174002 \\
(\mathrm{CO}-39-90)\end{array}$} & $06-02-94$ & -- & 6.9 & 0.1 & -85 & 504 & 64 \\
\hline & $06-07-94$ & -- & 7.4 & 0.1 & -102 & 504 & 97 \\
\hline & $06-10-94$ & 1,770 & 7.4 & 0.1 & -110 & 402 & -- \\
\hline & $06-13-94$ & 2,290 & 7.5 & 0.2 & -116 & 434 & -. \\
\hline & $06-20-94$ & 1,750 & 7.4 & 0.2 & -119 & 408 & 36 \\
\hline & $06-27-94$ & 2,130 & 7.5 & 0.2 & -119 & 410 & 44 \\
\hline & $06-30-94$ & 2,140 & 7.4 & 0.1 & -131 & 480 & 40 \\
\hline & $07-08-94$ & 2,180 & 7.5 & 0.2 & -110 & 468 & 46 \\
\hline & $07-13-94$ & 2,350 & 7.5 & 0.1 & -129 & 486 & 44 \\
\hline & $07-15-94$ & 2,070 & 7.5 & 0.1 & -125 & 464 & 38 \\
\hline & $07-18-94$ & 1,820 & 7.5 & 0.1 & -123 & 437 & 32 \\
\hline & $07-21-94$ & 2,210 & 7.6 & 0.1 & -100 & 408 & 38 \\
\hline & $07-25-94$ & 2,000 & 7.7 & 0.1 & -151 & 396 & 33 \\
\hline & $07-29-94$ & 2,070 & 7.7 & 0.1 & -90 & 352 & 37 \\
\hline & $08-04-94$ & 2,160 & 7.7 & 0.1 & -182 & 334 & 42 \\
\hline & $08-11-94$ & 2,290 & 7.5 & 0.1 & -163 & 344 & 46 \\
\hline & $08-31-94$ & 3,020 & 7.4 & -- & -105 & 348 & 90 \\
\hline & $09-16-94$ & 2,610 & 7.3 & 0.0 & -79 & 432 & 61 \\
\hline & $09-29-94$ & 3,460 & 7.7 & 0.1 & -102 & 418 & 87 \\
\hline & $10-19-94$ & 3,280 & 7.5 & 0.1 & -64 & 394 & 85 \\
\hline & $01-09-95$ & 2,720 & 7.5 & 0.1 & -103 & 326 & 71 \\
\hline & $02-10-95$ & 2,130 & 7.6 & 0.1 & -104 & 274 & 48 \\
\hline & $03-06-95$ & 1,800 & 7.6 & -- & -159 & 248 & 44 \\
\hline & 05-24-95 & 4,120 & 7.4 & 0.1 & -111 & 364 & 140 \\
\hline & $06-16-95$ & 1,830 & 7.5 & 0.1 & -140 & 244 & 30 \\
\hline & $06-21-95$ & 1,580 & 7.5 & 0.0 & -191 & 235 & 26 \\
\hline & $06-23-95$ & 2,090 & 7.5 & 0.0 & -204 & 244 & 43 \\
\hline & $06-29-95$ & 2,270 & 7.5 & 0.0 & -147 & 247 & 45 \\
\hline & $07-05-95$ & 2,150 & 7.6 & 0.1 & -134 & 236 & 44 \\
\hline & $07-10-95$ & 1,810 & 7.5 & 0.1 & -167 & 208 & 33 \\
\hline & $07-17-95$ & 1,920 & 7.5 & 0.0 & -128 & 208 & 39 \\
\hline & $07-28-95$ & 3,270 & 7.4 & 0.0 & -139 & 300 & 93 \\
\hline & 08-03-95 & 1,430 & 7.6 & 0.0 & -156 & 178 & 23 \\
\hline & 08-07-95 & 2,670 & 7.5 & 0.0 & -143 & 230 & 61 \\
\hline & $08-10-95$ & 3,450 & 7.4 & 0.0 & -130 & 276 & 90 \\
\hline & $08-14-95$ & 2,850 & 7.4 & 0.0 & -71 & 144 & 70 \\
\hline & $08-28-95$ & 3,290 & 7.5 & 0.1 & -105 & 245 & 82 \\
\hline & $09-11-95$ & 2,360 & 7.5 & 0.0 & -140 & 166 & 56 \\
\hline & $09-26-95$ & 1,800 & 7.7 & 0.1 & -128 & 213 & 38 \\
\hline & $11-13-95$ & 3,110 & 7.5 & 0.1 & -351 & 459 & 110 \\
\hline 442117098174003 & $06-02-94$ & 1,560 & 7.3 & 0.1 & -145 & 468 & 48 \\
\hline$(\mathrm{CO}-40-90)$ & $06-07-94$ & 1,650 & 7.5 & 0.1 & -132 & 408 & 45 \\
\hline
\end{tabular}




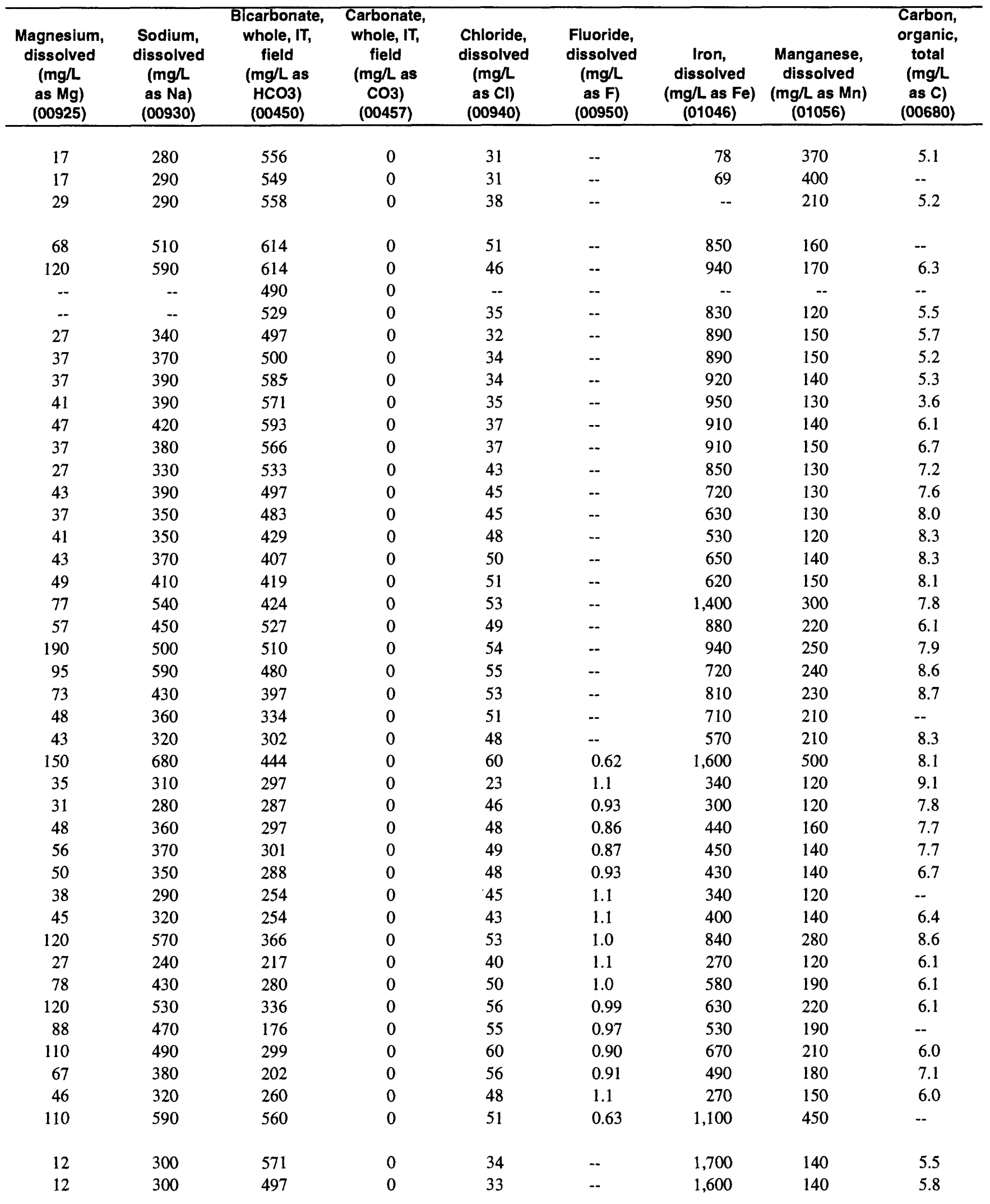


Table 13. Water-quality data obtained from plume-monitoring samples-Continued

\begin{tabular}{|c|c|c|c|c|c|c|c|}
\hline Station number & Date & $\begin{array}{c}\text { Specific } \\
\text { conductance, } \\
\text { field } \\
(\mu \mathrm{s} / \mathrm{cm}) \\
(00095)\end{array}$ & $\begin{array}{c}\text { pH, } \\
\text { field } \\
\text { (standard } \\
\text { units) } \\
(00400)\end{array}$ & $\begin{array}{c}\text { Dissolved } \\
\text { oxygen, } \\
\text { field } \\
\text { (mg/L) } \\
\text { (00300 }\end{array}$ & $\begin{array}{c}\text { Oxidation- } \\
\text { reduction } \\
\text { potential, } \\
\text { field } \\
(\mathrm{mV}) \\
(00090)\end{array}$ & $\begin{array}{c}\text { Alkalinity, } \\
\text { whole, } \\
\text { FET, field } \\
\text { (mg/L as } \\
\left.\mathrm{CaCO}_{3}\right) \\
(00410)\end{array}$ & $\begin{array}{c}\text { Calcium, } \\
\text { dissolved } \\
\text { (mg/L as Ca) } \\
(00915)\end{array}$ \\
\hline 442117098174003 & $06-10-94$ & 1,650 & 7.4 & 0.1 & -126 & 426 & -- \\
\hline \multirow[t]{46}{*}{ (CO-40-90)—Cont. } & $06-13-94$ & 1,720 & 7.4 & 0.1 & -136 & 428 & -- \\
\hline & $06-20-94$ & 1,560 & 7.4 & 0.1 & -134 & 390 & 40 \\
\hline & $06-27-94$ & 1,450 & 7.5 & 0.1 & -139 & 334 & 36 \\
\hline & $06-30-94$ & 1,360 & 7.5 & 0.1 & -155 & 344 & 27 \\
\hline & $07-08-94$ & 1,210 & 7.5 & 0.1 & -152 & 290 & 19 \\
\hline & $07-15-94$ & 1,110 & 7.8 & 0.1 & -177 & 250 & 17 \\
\hline & $07-18-94$ & 1,090 & 7.7 & 0.0 & -179 & 246 & 16 \\
\hline & $07-21-94$ & 1,090 & 7.8 & 0.1 & -164 & 228 & 16 \\
\hline & $07-25-94$ & 1,060 & 7.9 & 0.1 & -212 & 156 & 16 \\
\hline & $07-29-94$ & 1,030 & 7.8 & 0.1 & -185 & 196 & 19 \\
\hline & 08-04-94 & 1,030 & 7.9 & 0.1 & -213 & 206 & 17 \\
\hline & $08-11-94$ & 1,060 & 7.8 & 0.1 & -253 & 218 & 18 \\
\hline & $08-30-94$ & -- & -- & -- & -- & -- & 20 \\
\hline & $09-01-94$ & -- & -- & -- & -- & -- & 22 \\
\hline & $09-02-94$ & -- & -- & -- & -- & -- & 23 \\
\hline & $09-16-94$ & 1,160 & 7.5 & 0.0 & -133 & 256 & 23 \\
\hline & $10-19-94$ & 1,120 & 7.9 & 0.1 & -150 & 242 & 23 \\
\hline & $01-09-95$ & 1,060 & 7.8 & 0.1 & -160 & 280 & 20 \\
\hline & $02-10-95$ & 1,020 & 7.8 & 0.1 & -137 & 202 & 18 \\
\hline & $02-24-95$ & 1,000 & 7.7 & $\cdots$ & -137 & 192 & 18 \\
\hline & $03-06-95$ & 980 & 7.8 & -- & -176 & 190 & 18 \\
\hline & $05-24-95$ & 1,040 & 7.8 & 0.1 & -153 & 205 & 23 \\
\hline & $06-16-95$ & 1,140 & 7.6 & 0.1 & -169 & 190 & 18 \\
\hline & $06-21-95$ & 980 & 7.6 & 0.0 & -189 & 190 & 18 \\
\hline & $06-23-95$ & 970 & 7.7 & 0.0 & -245 & 166 & 17 \\
\hline & $06-26-95$ & 970 & 7.8 & 0.1 & -238 & 160 & 17 \\
\hline & $06-29-95$ & 970 & 7.8 & 0.0 & -198 & 150 & 19 \\
\hline & $07-05-95$ & 990 & 7.7 & 0.1 & -146 & 145 & 21 \\
\hline & $07-10-95$ & 1,000 & 7.7 & 0.1 & -191 & 149 & 21 \\
\hline & $07-13-95$ & 1,010 & 7.5 & 0.0 & -191 & 132 & 21 \\
\hline & $07-17-95$ & 1,000 & 7.6 & 0.0 & -178 & 140 & 22 \\
\hline & $07-20-95$ & 1,020 & 7.7 & 0.0 & -197 & 145 & 22 \\
\hline & $07-28-95$ & 1,030 & 7.8 & 0.0 & -192 & 140 & 22 \\
\hline & $08-03-95$ & 980 & 7.7 & 0.0 & -184 & 113 & 20 \\
\hline & $08-07-95$ & 980 & 7.9 & 0.0 & -203 & 112 & 20 \\
\hline & $08-10-95$ & 980 & 7.8 & 0.0 & -203 & 103 & 20 \\
\hline & $08-14-95$ & 960 & 7.8 & 0.0 & -135 & 121 & 21 \\
\hline & $08-17-95$ & 950 & 7.8 & 0.0 & -218 & 105 & 21 \\
\hline & $08-28-95$ & 900 & 7.9 & 0.0 & -187 & 102 & 24 \\
\hline & $08-31-95$ & 880 & 7.7 & 0.0 & -201 & 108 & 25 \\
\hline & 09-06-95 & 870 & 7.8 & 0.0 & -187 & 101 & 26 \\
\hline & $09-11-95$ & 860 & 7.8 & 0.0 & -197 & 84 & 27 \\
\hline & $09-19-95$ & 860 & 7.8 & 0.0 & -197 & 84 & 27 \\
\hline & $09-26-95$ & 1,040 & 7.9 & 0.1 & -139 & 164 & 30 \\
\hline & $09-29-95$ & 1,080 & 7.8 & 0.0 & -193 & 207 & 31 \\
\hline & $10-03-95$ & 1,090 & 7.8 & 0.1 & -157 & 238 & 31 \\
\hline
\end{tabular}




\begin{tabular}{|c|c|c|c|c|c|c|c|c|}
\hline $\begin{array}{c}\text { Magnesium, } \\
\text { dissolved } \\
\text { (mg/L } \\
\text { as Mg) } \\
(00925) \\
\end{array}$ & $\begin{array}{c}\text { Sodium, } \\
\text { dissolved } \\
\text { (mg/L } \\
\text { as Na) } \\
(00930) \\
\end{array}$ & $\begin{array}{c}\text { Bicarbonate, } \\
\text { whole, IT, } \\
\text { field } \\
\text { (mg/L as } \\
\text { HCO3) } \\
(00450) \\
\end{array}$ & $\begin{array}{c}\text { Carbonate, } \\
\text { whole, IT, } \\
\text { field } \\
\text { (mg/L as } \\
\text { CO3) } \\
\text { (00457) } \\
\end{array}$ & $\begin{array}{c}\text { Chloride, } \\
\text { dissolved } \\
\text { (mg/L } \\
\text { as Cl) } \\
(00940) \\
\end{array}$ & $\begin{array}{c}\text { Fluoride, } \\
\text { dissolved } \\
\text { (mg/L } \\
\text { as F) } \\
(00950) \\
\end{array}$ & $\begin{array}{c}\text { Iron, } \\
\text { dissolved } \\
\text { (mg/L as Fe) } \\
(01046)\end{array}$ & $\begin{array}{c}\text { Manganese, } \\
\text { dissolved } \\
\text { (mg/L as Mn) } \\
(01056)\end{array}$ & $\begin{array}{c}\text { Carbon } \\
\text { organic } \\
\text { total } \\
(\mathrm{mg} / \mathrm{L} \\
\text { as C) } \\
(00680\end{array}$ \\
\hline -- & -- & 519 & 0 & -- & -- & -- & -. & -. \\
\hline -- & -- & 522 & 0 & 32 & -- & 2,000 & 150 & 5.1 \\
\hline 12 & 300 & 475 & 0 & 39 & -- & 1,600 & 130 & 6.4 \\
\hline 10 & 270 & 407 & 0 & 42 & -. & 1,400 & 110 & 8.5 \\
\hline 9.5 & 250 & 419 & 0 & 48 & -. & 1,200 & 100 & 7.1 \\
\hline 6.7 & 220 & 354 & 0 & 49 & .. & 990 & 78 & 8.7 \\
\hline 6.0 & 200 & 305 & 0 & 47 & -- & 750 & 82 & 8.4 \\
\hline 6.1 & 200 & 300 & 0 & 46 & -- & 710 & 86 & 8.3 \\
\hline 6.0 & 200 & 278 & 0 & 45 & -- & 680 & 91 & 8.1 \\
\hline 6.6 & 190 & 190 & 0 & 45 & -- & 620 & 98 & 8.2 \\
\hline 5.3 & 180 & 239 & 0 & 42 & -- & 540 & 98 & 8.2 \\
\hline 5.4 & 180 & 251 & 0 & 42 & -. & 530 & 100 & 7.6 \\
\hline 6.1 & 190 & 266 & 0 & 43 & -- & 610 & 110 & 7.8 \\
\hline 6.6 & 200 & -- & -- & 45 & -- & 590 & 120 & 7.9 \\
\hline 7.2 & 210 & -- & -- & 45 & -- & 680 & 130 & 8.1 \\
\hline 7.0 & 210 & -- & -- & 45 & -- & 720 & 130 & 7.9 \\
\hline 6.0 & 210 & 312 & 0 & 44 & -- & 720 & 130 & 8.2 \\
\hline 5.9 & 210 & 295 & 0 & 45 & -- & 700 & 120 & 6.7 \\
\hline 6.3 & 190 & 341 & 0 & 43 & -- & 560 & 110 & 8.4 \\
\hline 5.6 & 190 & 246 & 0 & 42 & -- & 510 & 120 & - \\
\hline 5.2 & 180 & 234 & 0 & 41 & -- & 480 & 110 & -- \\
\hline 5.1 & 180 & 232 & 0 & 40 & -- & 460 & 120 & 7.3 \\
\hline 6.2 & 190 & 250 & 0 & 44 & 0.83 & 410 & 150 & 8.1 \\
\hline 5.8 & 190 & 232 & 0 & 44 & 0.86 & 450 & 150 & 10 \\
\hline 5.5 & 180 & 232 & 0 & 44 & 0.86 & 420 & 140 & 8.6 \\
\hline 5.3 & 180 & 202 & 0 & 45 & 0.84 & 420 & 130 & 7.8 \\
\hline 5.2 & 180 & 195 & 0 & 45 & 0.84 & 410 & 130 & 8.0 \\
\hline 5.4 & 180 & 183 & 0 & 45 & 0.80 & 410 & 110 & 11 \\
\hline 5.5 & 170 & 177 & 0 & 46 & 0.77 & 390 & 140 & 6.6 \\
\hline 5.6 & 170 & 182 & 0 & 43 & 0.86 & 440 & 140 & 7.0 \\
\hline 5.8 & 180 & 161 & 0 & 45 & 0.88 & 430 & 140 & 7.1 \\
\hline 5.7 & 180 & 171 & 0 & 41 & 0.55 & 450 & 150 & 8.4 \\
\hline 6.1 & 180 & 177 & 0 & 46 & 0.82 & 540 & 140 & 6.5 \\
\hline 8.2 & 190 & 171 & 0 & 50 & 0.79 & 460 & 140 & 9.6 \\
\hline 6.2 & 170 & 138 & 0 & 45 & 0.73 & 440 & 160 & 7.1 \\
\hline 6.2 & 170 & 137 & 0 & 50 & 0.68 & 440 & 160 & 5.9 \\
\hline 6.8 & 200 & 126 & 0 & 50 & 0.66 & 420 & 160 & -- \\
\hline 6.2 & 160 & 148 & 0 & 49 & 0.62 & 390 & 170 & 6.0 \\
\hline -- & 160 & 128 & 0 & 48 & 0.62 & 430 & 160 & 7.1 \\
\hline 7.2 & 140 & 124 & 0 & 44 & 0.59 & 440 & 200 & 5.3 \\
\hline 7.0 & 140 & 132 & 0 & 44 & 0.58 & -- & 200 & -- \\
\hline 7.6 & 130 & 123 & 0 & 42 & 0.58 & 450 & 210 & 6.0 \\
\hline 7.8 & 130 & 102 & 0 & 42 & 0.59 & 520 & 220 & 6.6 \\
\hline 7.8 & 130 & 102 & 0 & 42 & 0.59 & 520 & 220 & 6.6 \\
\hline 8.0 & 190 & 200 & 0 & 49 & 0.78 & 540 & 230 & 6.3 \\
\hline 7.4 & 190 & 252 & 0 & 48 & 0.74 & 560 & 220 & 7.2 \\
\hline 8.0 & 210 & 290 & 0 & 45 & 0.79 & 540 & 220 & 7.9 \\
\hline
\end{tabular}


Table 13. Water-quality data obtained from plume-monitoring samples-Continued

\begin{tabular}{|c|c|c|c|c|c|c|c|}
\hline Station number & Date & $\begin{array}{c}\text { Specific } \\
\text { conductance, } \\
\text { field . } \\
(\mu \mathrm{s} / \mathrm{cm}) \\
(00095)\end{array}$ & $\begin{array}{c}\begin{array}{c}\mathrm{pH}, \\
\text { field } \\
\text { (standard }\end{array} \\
\text { units) } \\
(00400) \\
\end{array}$ & $\begin{array}{c}\text { Dissolved } \\
\text { oxygen, } \\
\text { field } \\
(\mathrm{mg} / \mathrm{L}) \\
(00300 \\
\end{array}$ & $\begin{array}{l}\text { Oxidation- } \\
\text { reduction } \\
\text { potential, } \\
\text { field } \\
(\mathrm{mV}) \\
(00090)\end{array}$ & $\begin{array}{l}\text { Alkalinity, } \\
\text { whole, } \\
\text { FET, field } \\
\left(\mathrm{mg}^{2} \mathrm{~L} \text { as }\right. \\
\left.\mathrm{CaCO}_{3}\right) \\
(00410)\end{array}$ & $\begin{array}{c}\text { Calcium, } \\
\text { dissolved } \\
\text { (mg/L as Ca) } \\
(00915)\end{array}$ \\
\hline \multirow{8}{*}{$\begin{array}{l}442117098174003 \\
\quad(C O-40-90) \text {-Cont. }\end{array}$} & $10-06-95$ & 1,130 & 7.7 & 0.1 & -100 & 270 & 32 \\
\hline & $10-09-95$ & 1,150 & 7.8 & 0.1 & -- & 278 & 33 \\
\hline & $10-13-95$ & 1,160 & 7.7 & 0.0 & -210 & 270 & 34 \\
\hline & $10-16-95$ & 1,190 & 7.8 & -- & -- & 280 & 35 \\
\hline & $10-20-95$ & 1,170 & 7.6 & 0.1 & -177 & 300 & 37 \\
\hline & $11-03-95$ & 1,220 & 7.8 & -- & -136 & 317 & 38 \\
\hline & $11-06-95$ & 1,200 & 7.6 & - & -372 & 314 & 38 \\
\hline & $11-13-95$ & 1,250 & 7.8 & 0.1 & -116 & 330 & 39 \\
\hline \multirow{17}{*}{$\begin{array}{l}442117098174001 \\
(\mathrm{CO}-17-90)\end{array}$} & 03-06-95 & 1,100 & 7.6 & -- & -188 & 254 & 21 \\
\hline & $05-24-95$ & 1,130 & 7.7 & 0.1 & -165 & 248 & 24 \\
\hline & $06-16-95$ & 600 & 7.5 & 0.1 & -151 & 246 & 19 \\
\hline & $06-21-95$ & 1,110 & 7.4 & 0.0 & -160 & 268 & 20 \\
\hline & $06-23-95$ & 1,080 & 7.5 & 0.1 & -183 & 234 & 20 \\
\hline & $06-26-95$ & 1,050 & 7.6 & 0.1 & -184 & 219 & 18 \\
\hline & $06-29-95$ & 1,030 & 7.7 & 0.0 & -195 & 204 & 19 \\
\hline & $07-10-95$ & 1,040 & 7.6 & 0.0 & -189 & 175 & 20 \\
\hline & $07-17-95$ & 1,070 & 7.5 & 0.0 & -170 & 166 & 21 \\
\hline & $07-28-95$ & 1,120 & 7.6 & 0.0 & -190 & 171 & 22 \\
\hline & 08-07-95 & 1,030 & 7.8 & 0.0 & -192 & 116 & 19 \\
\hline & $08-14-95$ & 1,000 & 7.7 & 0.1 & -139 & 127 & 19 \\
\hline & $08-28-95$ & 940 & 7.8 & 0.1 & -144 & 115 & 26 \\
\hline & $09-06-95$ & 900 & 7.8 & 0.1 & -159 & 107 & 30 \\
\hline & $09-11-95$ & 890 & 7.7 & 0.0 & -186 & 108 & 28 \\
\hline & $10-03-95$ & 1,080 & 7.8 & 0.1 & -115 & 261 & 27 \\
\hline & $11-13-95$ & 1,300 & 7.8 & 0.1 & -237 & 386 & 37 \\
\hline \multirow{8}{*}{$\begin{array}{l}442115098174202 \\
(\mathrm{CO}-63-90)\end{array}$} & $06-02-94$ & 1,650 & 7.0 & 0.1 & -149 & 460 & 47 \\
\hline & $06-08-94$ & 1,710 & 7.4 & 0.1 & -123 & 450 & 50 \\
\hline & $06-27-94$ & 1,620 & 7.5 & 0.1 & -134 & 468 & -- \\
\hline & $06-30-94$ & 1,650 & 7.5 & 0.1 & -138 & 494 & 44 \\
\hline & 07-05-94 & 1,630 & 7.4 & 0.1 & -136 & 480 & 44 \\
\hline & $07-08-94$ & 1,660 & 7.5 & 0.0 & -139 & 478 & 44 \\
\hline & $07-13-94$ & 1,650 & 7.5 & 0.1 & -155 & 466 & 42 \\
\hline & $08-31-94$ & 1,550 & 7.3 & -- & $\cdot-129$ & 420 & 46 \\
\hline \multirow{11}{*}{$\begin{array}{l}442115098174203 \\
(\text { CO-64-90) }\end{array}$} & 06-02-94 & 1,740 & 7.0 & 0.1 & -121 & 468 & 55 \\
\hline & $06-08-94$ & 1,780 & 7.4 & 0.1 & -101 & 472 & 53 \\
\hline & $06-27-94$ & 1,680 & 7.5 & 0 & -101 & 486 & -- \\
\hline & 06-30-94 & 1,670 & 7.5 & 0.1 & -103 & 474 & 45 \\
\hline & 07-05-94 & 1,700 & 7.5 & 0.1 & -107 & 470 & 46 \\
\hline & $10-19-94$ & 1,700 & 7.3 & 0.1 & -137 & 442 & 51 \\
\hline & 01-09-95 & 1,660 & 7.5 & 0.1 & -100 & 526 & 52 \\
\hline & 03-07-95 & 1,640 & 7.5 & -- & -100 & 470 & 50 \\
\hline & 05-24-95 & 1,710 & 7.5 & 0.1 & -106 & 438 & 59 \\
\hline & 06-29-95 & 1,630 & 7.3 & 0.0 & -194 & 468 & 51 \\
\hline & $08-31-95$ & 1,590 & 7.5 & 0.0 & -137 & 445 & 49 \\
\hline
\end{tabular}




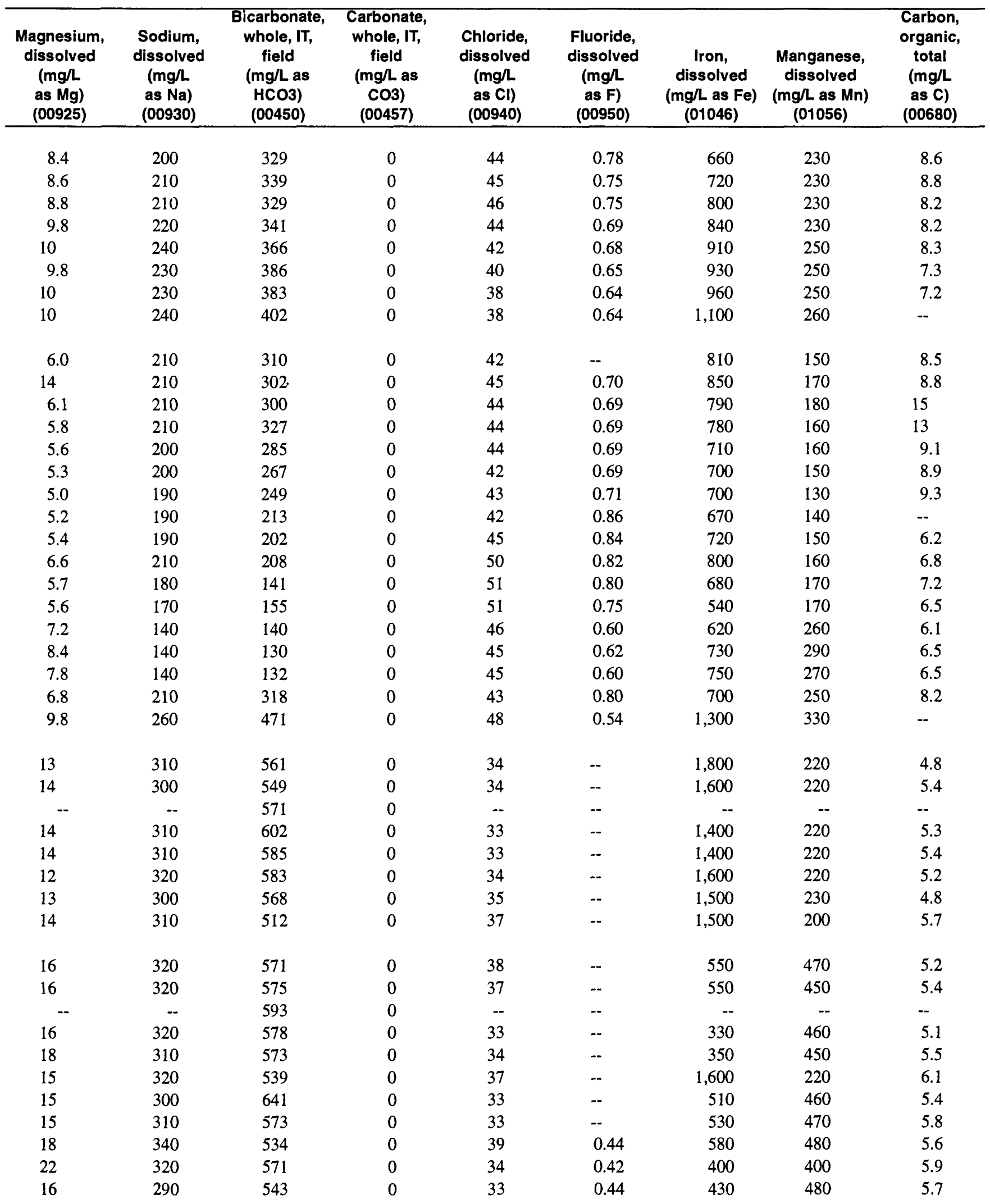


Table 13. Water-quality data obtained from plume-monitoring samples-Continued

\begin{tabular}{|c|c|c|c|c|c|c|c|}
\hline Station number & Date & $\begin{array}{c}\text { Specific } \\
\text { conductance, } \\
\text { field } \\
(\mu \mathrm{s} / \mathrm{cm}) \\
(00095) \\
\end{array}$ & $\begin{array}{c}\text { pH, } \\
\text { field } \\
\text { (standard } \\
\text { units) } \\
(00400) \\
\end{array}$ & $\begin{array}{c}\text { Dissolved } \\
\text { oxygen, } \\
\text { field } \\
\text { (mg/L) } \\
(00300 \\
\end{array}$ & $\begin{array}{l}\text { Oxidation- } \\
\text { reduction } \\
\text { potential, } \\
\text { field } \\
(\mathrm{mV}) \\
(00090) \\
\end{array}$ & $\begin{array}{l}\text { Alkalinity, } \\
\text { whole, } \\
\text { FET, field } \\
\text { (mg/L as } \\
\left.\mathrm{CaCO}_{3}\right) \\
(00410) \\
\end{array}$ & $\begin{array}{c}\text { Calcium, } \\
\text { dissolved } \\
(\mathrm{mg} / \mathrm{L} \text { as Ca) } \\
(00915) \\
\end{array}$ \\
\hline \multirow{13}{*}{$\begin{array}{c}442115098173903 \\
(\mathrm{CO}-58-90)\end{array}$} & $06-03-94$ & -- & 6.6 & 0.1 & -75 & 500 & 220 \\
\hline & $06-08-94$ & -- & 7.3 & 0.1 & -65 & 474 & 160 \\
\hline & $06-30-94$ & 2,010 & 7.3 & 0.1 & -58 & 468 & 60 \\
\hline & $07-29-94$ & 1,880 & 7.5 & 0.1 & -153 & 498 & 60 \\
\hline & 08-04-94 & 2,250 & 7.6 & 0.1 & -182 & 482 & 84 \\
\hline & $08-11-94$ & -- & 7.1 & 0.1 & -213 & 486 & 130 \\
\hline & $09-01-94$ & 3,430 & 7.0 & - & -72 & 468 & 280 \\
\hline & $09-16-94$ & 4,250 & 6.9 & 0.0 & -45 & 520 & 280 \\
\hline & $09-29-94$ & 4,220 & 7.3 & 0.1 & -78 & 490 & 290 \\
\hline & $10-19-94$ & 2,940 & 7.3 & 0.1 & -89 & 466 & 160 \\
\hline & $01-10-95$ & 2,120 & 7.4 & 0.2 & -53 & 532 & 78 \\
\hline & $02-10-95$ & 2,320 & 7.4 & 0.1 & -116 & 486 & 100 \\
\hline & $03-06-95$ & 2,590 & 7.3 & -- & -93 & 492 & 130 \\
\hline \multirow{12}{*}{$\begin{array}{l}442115098173901 \\
(\mathrm{CO}-56-90)\end{array}$} & $06-08-94$ & 1,660 & 7.5 & 0.1 & -132 & 472 & 30 \\
\hline & $06-30-94$ & 1,740 & 7.4 & 0.1 & -128 & 478 & 26 \\
\hline & $07-29-94$ & 1,810 & 7.6 & 0.1 & -178 & 476 & 32 \\
\hline & $08-04-94$ & 1,790 & 7.6 & 0.1 & -192 & 474 & 33 \\
\hline & 08-11-94 & 1,800 & 7.3 & 0.1 & -244 & 490 & 33 \\
\hline & 09-01-94 & 1,400 & 7.4 & -- & -141 & 418 & 34 \\
\hline & $09-16-94$ & 1,770 & 7.3 & 0.0 & -111 & 524 & 32 \\
\hline & $09-29-94$ & 1,760 & 7.8 & 0.1 & -133 & 472 & 31 \\
\hline & $10-19-94$ & 1,750 & 7.6 & 0.1 & -139 & 464 & 33 \\
\hline & 01-10-95 & 1,770 & 7.5 & 0.1 & -140 & 540 & 34 \\
\hline & $02-10-95$ & 1,750 & 7.5 & 0.1 & -135 & 474 & 33 \\
\hline & $03-06-95$ & 1,760 & 7.5 & -- & -155 & 476 & 34 \\
\hline \multirow{20}{*}{$\begin{array}{c}442117098174008 \\
\text { (Recharge well) }\end{array}$} & $06-03-94$ & 830 & 7.3 & 6.6 & 239 & 52 & 37 \\
\hline & $06-08-94$ & 790 & 8.0 & 6.8 & 329 & 52 & 29 \\
\hline & $09-19-95$ & 790 & 7.7 & -- & -61 & 64 & 41 \\
\hline & $09-20-95$ & 760 & 7.4 & $\cdots$ & -75 & 66 & 44 \\
\hline & $09-21-95$ & 740 & 7.4 & -- & -118 & 70 & 44 \\
\hline & $09-22-95$ & 740 & 7.4 & -- & -91 & 81 & 44 \\
\hline & $09-26-95$ & 820 & 7.6 & 0.1 & -55 & 110 & 52 \\
\hline & 09-29-95 & 880 & 7.6 & -- & -124 & 160 & 61 \\
\hline & $10-02-95$ & 1,800 & 7.5 & $-\cdot$ & -- & 186 & 66 \\
\hline & $10-03-95$ & 1,060 & 7.4 & -- & -117 & 214 & 67 \\
\hline & $10-04-95$ & 1,150 & 7.4 & -- & -- & 216 & 67 \\
\hline & $10-05-95$ & 1,190 & 7.5 & -- & -- & 246 & 68 \\
\hline & $10-06-95$ & 1,100 & 7.6 & -- & -135 & 264 & 70 \\
\hline & $10-09-95$ & 1,240 & 7.5 & -- & -340 & 318 & 70 \\
\hline & $10-10-95$ & 1,250 & 7.7 & -- & -381 & 318 & 68 \\
\hline & $10-11-95$ & 1,270 & 7.6 & -- & -217 & 337 & 68 \\
\hline & $10-13-95$ & 1,300 & 7.5 & 0.1 & -176 & 315 & 68 \\
\hline & $10-16-95$ & 1,350 & 7.5 & -- & -- & 379 & 66 \\
\hline & $10-18-95$ & 1,350 & 7.5 & -- & -- & 377 & 67 \\
\hline & $10-20-95$ & 1,380 & 7.6 & -- & -- & 393 & 65 \\
\hline
\end{tabular}




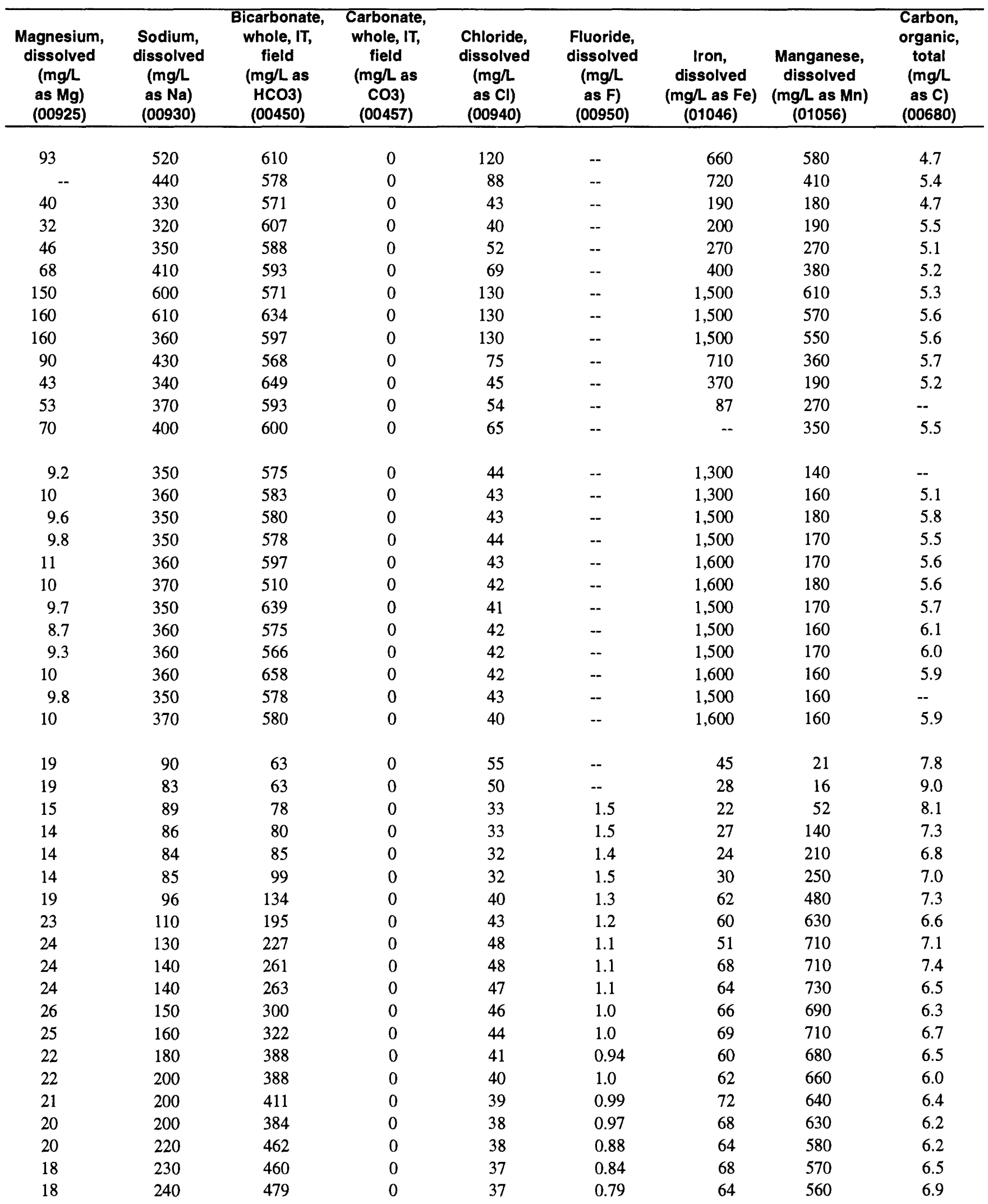


Table 13. Water-quality data obtained from plume-monitoring samples-Continued

\begin{tabular}{|c|c|c|c|c|c|c|c|}
\hline Station number & Date & $\begin{array}{c}\text { Specific } \\
\text { conductance, } \\
\text { field } \\
(\mu \mathrm{s} / \mathrm{cm}) \\
(00095) \\
\end{array}$ & $\begin{array}{c}\mathrm{pH}, \\
\text { field } \\
\text { (standard } \\
\text { units) } \\
(00400) \\
\end{array}$ & $\begin{array}{c}\text { Dissolved } \\
\text { oxygen, } \\
\text { field } \\
\text { (mg/l) } \\
(00300 \\
\end{array}$ & $\begin{array}{l}\text { Oxidation- } \\
\text { reduction } \\
\text { potential, } \\
\text { field } \\
(\mathrm{mV}) \\
(00090) \\
\end{array}$ & $\begin{array}{c}\text { Alkalinity, } \\
\text { whole, } \\
\text { FET, field } \\
\left(\mathrm{mg}^{\prime} \mathrm{L} \text { as }\right. \\
\left.\mathrm{CaCO}_{3}\right) \\
(00410)\end{array}$ & $\begin{array}{c}\text { Calcium, } \\
\text { dissolved } \\
\text { (mg/L as Ca) } \\
(00915)\end{array}$ \\
\hline 442117098174008 & $10-30-95$ & 1,400 & 7.6 & - & - & 388 & 64 \\
\hline \multirow[t]{3}{*}{ (Recharge well)—Cont. } & $11-01-95$ & 1,420 & 7.5 & -- & -- & 368 & 62 \\
\hline & $11-03-95$ & 1,380 & 7.6 & -- & -- & 380 & 63 \\
\hline & $11-06-95$ & 1,350 & 7.5 & -- & -310 & 386 & 62 \\
\hline 442117098174009 & $06-03-94$ & 810 & 7.3 & 6.1 & 326 & -- & 42 \\
\hline (Recharge well & $06-08-94$ & 790 & 8.0 & 6.8 & 272 & 60 & 29 \\
\hline \multirow[t]{32}{*}{ injectate) } & $06-13-94$ & 760 & 8.4 & -- & 292 & 46 & -- \\
\hline & $06-16-94$ & 750 & 8.6 & 7.5 & 321 & 48 & 27 \\
\hline & $06-20-94$ & 770 & 8.6 & 7.0 & 268 & 56 & 28 \\
\hline & $06-27-94$ & 780 & 8.7 & 6.9 & 263 & 52 & 27 \\
\hline & $07-08-94$ & 750 & 8.9 & 6.6 & 249 & 66 & -- \\
\hline & $07-15-94$ & 570 & 8.6 & 6.9 & 169 & 52 & 33 \\
\hline & $07-21-94$ & 860 & 8.6 & 6.4 & -- & 52 & 37 \\
\hline & $07-29-94$ & 810 & 8.7 & 6.4 & 140 & 56 & 38 \\
\hline & $08-30-94$ & 1,040 & 7.3 & 0.5 & 47 & 146 & 56 \\
\hline & $08-30-94$ & 950 & 7.7 & 0.2 & 66 & 110 & 49 \\
\hline & $08-30-94$ & 910 & 7.7 & 0.2 & 70 & 88 & 47 \\
\hline & $08-30-94$ & 890 & 7.7 & 0.1 & 96 & 94 & 45 \\
\hline & $08-31-94$ & 920 & 7.7 & 0.2 & 47 & 90 & 46 \\
\hline & $08-31-94$ & 900 & 7.5 & 0.3 & 73 & 84 & 46 \\
\hline & $08-31-94$ & 920 & 7.4 & -- & 79 & 86 & 47 \\
\hline & $09-01-94$ & 930 & 7.5 & -- & 43 & 78 & 47 \\
\hline & $09-01-94$ & 920 & 7.5 & -- & 88 & 64 & 48 \\
\hline & 09-01-94 & 920 & 7.4 & -- & 86 & 82 & 49 \\
\hline & $09-02-94$ & 900 & 7.5 & -- & 56 & 78 & 50 \\
\hline & $06-16-95$ & 900 & 7.7 & 6.3 & 296 & 38 & 46 \\
\hline & $06-21-95$ & 850 & 7.8 & 6.9 & -- & 22 & 42 \\
\hline & $06-30-95$ & 850 & 8.3 & 6.7 & 109 & 52 & 43 \\
\hline & $07-05-95$ & 840 & 8.5 & 7.6 & 196 & 49 & 42 \\
\hline & $07-13-95$ & 790 & 8.2 & 6.1 & 278 & 46 & 44 \\
\hline & $07-20-95$ & 780 & 8.5 & 6.0 & 297 & 33 & 42 \\
\hline & $07-28-95$ & 760 & 8.4 & 5.6 & 290 & 57 & 40 \\
\hline & $08-03-95$ & 730 & 8.6 & 6.9 & 314 & 62 & 35 \\
\hline & $08-10-95$ & 710 & 8.7 & 6.5 & 293 & 48 & 36 \\
\hline & $08-17-95$ & 700 & 8.7 & 6.1 & 298 & 51 & 37 \\
\hline & $08-31-95$ & 680 & 8.7 & 5.6 & 194 & 56 & 38 \\
\hline & $09-06-95$ & 710 & 8.6 & 5.7 & 293 & 43 & 38 \\
\hline & $09-11-95$ & 710 & 8.7 & 5.8 & 306 & 41 & 37 \\
\hline 442113098174202 & $06-02-94$ & 1,620 & 6.9 & 0.1 & -157 & 476 & 50 \\
\hline \multirow[t]{6}{*}{$(\mathrm{CO}-60-90)$} & $06-07-94$ & 1,700 & 7.5 & 0.1 & -145 & 482 & 48 \\
\hline & $06-10-94$ & 1,700 & 7.4 & 0.1 & -137 & 422 & -- \\
\hline & $06-13-94$ & 1,680 & 7.5 & -- & -141 & 436 & -- \\
\hline & $06-20-94$ & 1,690 & 7.4 & 0.1 & -144 & 410 & 46 \\
\hline & $06-27-94$ & 1,630 & 7.4 & 0.1 & -151 & 404 & 44 \\
\hline & $06-30-94$ & 1,450 & 7.4 & 0.1 & -159 & 400 & 32 \\
\hline
\end{tabular}




\begin{tabular}{|c|c|c|c|c|c|c|c|c|}
\hline $\begin{array}{c}\text { Magnesium, } \\
\text { dissolved } \\
(\mathrm{mg} / \mathrm{h} \\
\text { as Mg) } \\
(00925) \\
\end{array}$ & $\begin{array}{c}\text { Sodium, } \\
\text { dissolved } \\
(\mathrm{mg} / \mathrm{L} \\
\text { as Na) } \\
(00930) \\
\end{array}$ & $\begin{array}{l}\text { Bicarbonate, } \\
\text { whole, IT, } \\
\text { field } \\
\text { (mg/L as } \\
\text { HCO3) } \\
(00450) \\
\end{array}$ & $\begin{array}{c}\text { Carbonate, } \\
\text { whole, IT, } \\
\text { field } \\
\text { (mg/L as } \\
\text { CO3) } \\
(00457) \\
\end{array}$ & $\begin{array}{c}\text { Chloride, } \\
\text { dissolved } \\
\text { (mg/L. } \\
\text { as CI) } \\
(00940) \\
\end{array}$ & $\begin{array}{c}\text { Fluoride, } \\
\text { dissolved } \\
\text { (mg/L } \\
\text { as F) } \\
(00950) \\
\end{array}$ & $\begin{array}{c}\text { Iron, } \\
\text { dissolved } \\
(\mathrm{mg} / \mathrm{L} \text { as Fe) } \\
(01046)\end{array}$ & $\begin{array}{c}\text { Manganese, } \\
\text { dissolved } \\
\text { (mg/L as Mn) } \\
(01056)\end{array}$ & $\begin{array}{c}\text { Carbon, } \\
\text { organic, } \\
\text { total } \\
(\mathrm{mg} / \mathrm{L} \\
\text { as C) } \\
(00680) \\
\end{array}$ \\
\hline 17 & 230 & 473 & 0 & 36 & 0.85 & 180 & 590 & 6.5 \\
\hline 16 & 240 & 449 & 0 & 36 & 0.82 & 78 & 550 & 5.8 \\
\hline 17 & 250 & 463 & 0 & 36 & 0.81 & 62 & 530 & 7.0 \\
\hline 16 & 250 & 471 & 0 & 36 & 0.76 & 55 & 530 & 6.3 \\
\hline 20 & 94 & -. & -- & 57 & -- & 15 & 25 & 7.0 \\
\hline 20 & 85 & 73 & 0 & 51 & -- & 3 & 16 & 8.7 \\
\hline-- & -. & 56 & -- & 47 & -- & -- & 7 & 7.7 \\
\hline 21 & 82 & 59 & -- & 48 & -- & 12 & 6 & 7.7 \\
\hline 21 & 83 & 68 & -- & 45 & -- & 8 & 5 & 7.4 \\
\hline 22 & 80 & 63. & -- & 45 & - & 4 & 0 & 8.0 \\
\hline 13 & 87 & 80 & .- & 44 & -. & 5 & 6 & -- \\
\hline 13 & 49 & 63 & -- & 30 & -- & -. & 4 & -- \\
\hline 18 & 94 & 63 & -- & 56 & -- & 26 & 12 & 6.8 \\
\hline 10 & 93 & 68 & -- & 52 & -. & 2 & 1 & 6.4 \\
\hline 22 & 110 & 178 & 0 & 56 & -- & 130 & 87 & 10 \\
\hline 19 & 110 & 134 & 0 & 53 & -- & 85 & 81 & 7.9 \\
\hline 18 & 100 & 107 & 0 & 53 & -- & 75 & 84 & 7.3 \\
\hline 18 & 100 & 115 & 0 & 53 & -- & 95 & 93 & 7.3 \\
\hline 19 & 100 & 110 & 0 & 55 & -- & 60 & 160 & 5.9 \\
\hline 18 & 100 & 102 & 0 & 55 & -- & 56 & 180 & 6.5 \\
\hline 18 & 110 & 105 & 0 & 56 & -- & 50 & 200 & 6.8 \\
\hline 17 & 100 & 95 & 0 & 57 & -- & 50 & 280 & 5.8 \\
\hline 18 & 100 & 78 & 0 & 57 & -- & 53 & 310 & 6.0 \\
\hline 18 & 100 & 100 & 0 & 57 & -- & 56 & 330 & 5.3 \\
\hline 19 & 99 & 95 & 0 & 54 & -- & 57 & 410 & 5.4 \\
\hline 21 & 79 & 46 & 0 & 48 & 1.2 & 6 & 64 & 7.6 \\
\hline 22 & 87 & 27 & 0 & 50 & 1.3 & 6 & 34 & 7.7 \\
\hline 22 & 95 & 63 & -- & 52 & 1.4 & 0 & 13 & 8.4 \\
\hline 21 & 88 & 60 & -- & 50 & 1.3 & 2 & 3 & 8.2 \\
\hline 15 & 87 & 56 & 0 & 44 & 1.5 & 0 & 4 & 7.3 \\
\hline 15 & 87 & 40 & -- & 40 & 1.4 & 0 & 0 & 8.4 \\
\hline 15 & 88 & 70 & -- & 42 & 1.4 & 0 & 6 & 11 \\
\hline 15 & 84 & 76 & -- & 35 & 1.4 & 0 & 2 & 8.2 \\
\hline 14 & 76 & 59 & -- & 35 & 1.5 & 0 & 7 & 9.8 \\
\hline 12 & 85 & 62 & .- & 36 & 1.5 & 0 & 7 & 7.2 \\
\hline 12 & 76 & 68 & -- & 31 & 1.4 & 0 & 3 & 7.8 \\
\hline 14 & 78 & 52 & -- & 32 & 1.4 & 8 & 2 & 8.5 \\
\hline 15 & 79 & 50 & -- & 31 & 1.4 & 0 & 2 & 8.0 \\
\hline-- & -- & 580 & 0 & 36 & -- & 2,300 & 150 & 4.8 \\
\hline 12 & 320 & 588 & 0 & 35 & -- & 2,200 & 140 & 6.5 \\
\hline- & -- & 515 & 0 & -- & -- & -- & -- & -- \\
\hline -- & -- & 532 & 0 & 34 & -- & 2,500 & 150 & 4.9 \\
\hline 13 & 320 & 500 & 0 & 34 & .- & 2,200 & 150 & 5.1 \\
\hline 12 & 300 & 493 & 0 & 43 & -- & 2,100 & 140 & 6.9 \\
\hline 11 & 270 & 488 & 0 & 47 & -- & 1,700 & 110 & 4.8 \\
\hline
\end{tabular}


Table 13. Water-quality data obtained from plume-monitoring samples-Continued

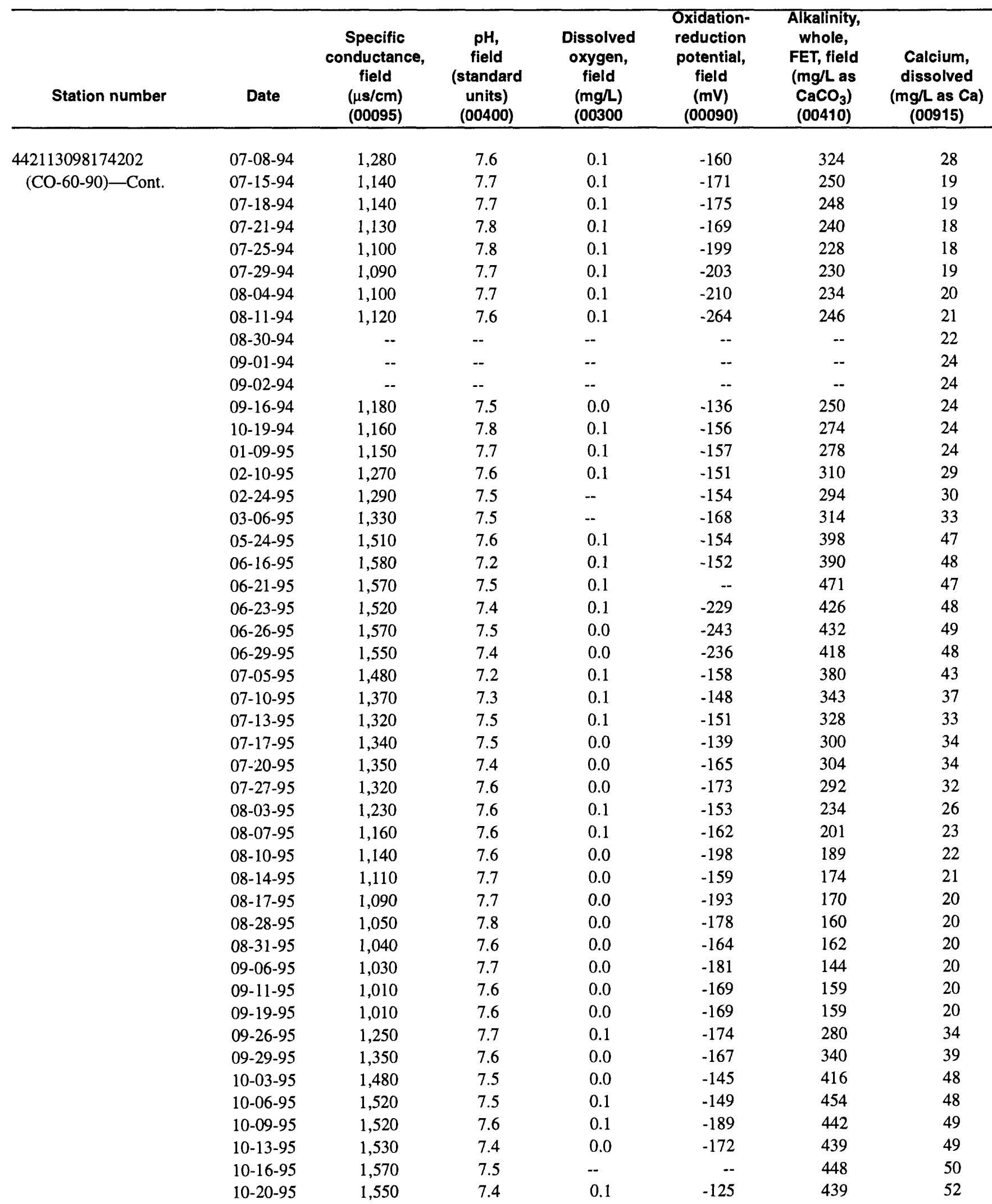




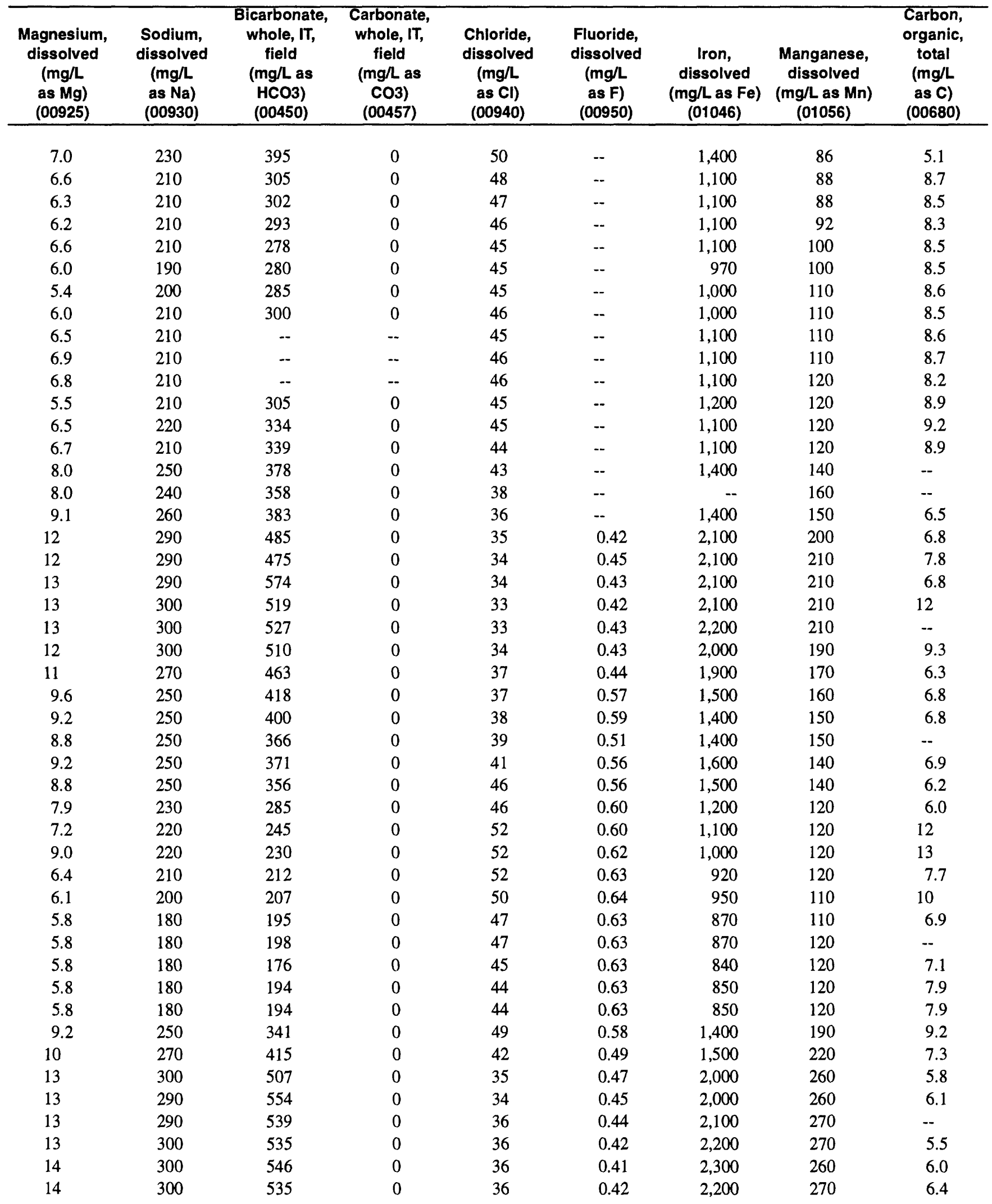


Table 13. Water-quality data obtained from plume-monitoring samples-Continued

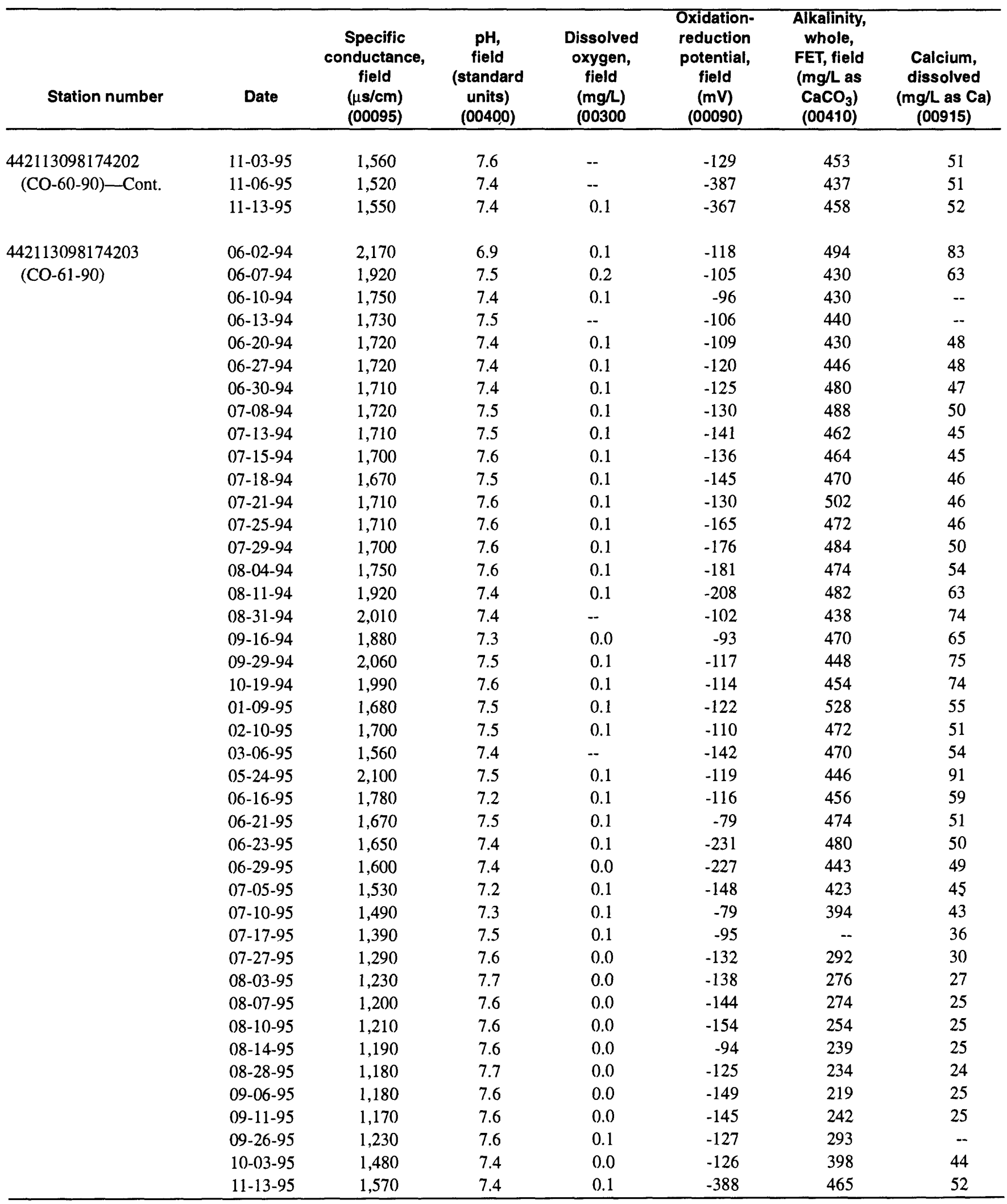




\begin{tabular}{|c|c|c|c|c|c|c|c|c|}
\hline $\begin{array}{c}\text { Magnesium, } \\
\text { dissolved } \\
\text { (mg/L } \\
\text { as Mg) } \\
(00925) \\
\end{array}$ & $\begin{array}{c}\text { Sodium, } \\
\text { dissolved } \\
\text { (mg/L } \\
\text { as } \mathrm{Na}) \\
(00930) \\
\end{array}$ & $\begin{array}{c}\text { Bicarbonate, } \\
\text { whole, IT, } \\
\text { field } \\
\text { (mg/L as } \\
\text { HCO3) } \\
(00450) \\
\end{array}$ & $\begin{array}{c}\text { Carbonate, } \\
\text { whole, IT, } \\
\text { field } \\
\text { (mg/L as } \\
\text { CO3) } \\
(00457) \\
\end{array}$ & $\begin{array}{c}\text { Chloride, } \\
\text { dissolved } \\
\text { (mg/L } \\
\text { as Cl) } \\
(00940) \\
\end{array}$ & $\begin{array}{c}\text { Fluoride, } \\
\text { dissolved } \\
\text { (mg/L } \\
\text { as F) } \\
(00950) \\
\end{array}$ & $\begin{array}{c}\text { Iron, } \\
\text { dissolved } \\
\text { (mg/ as Fe) } \\
(01046)\end{array}$ & $\begin{array}{c}\text { Manganese, } \\
\text { dissolved } \\
\text { (mg/L as Mn) } \\
(01056)\end{array}$ & $\begin{array}{c}\text { Carbon, } \\
\text { organic, } \\
\text { total } \\
(\mathrm{mg} / \mathrm{L} \\
\text { as C) } \\
(00680) \\
\end{array}$ \\
\hline 14 & 310 & 552 & 0 & 36 & 0.41 & 2,300 & 260 & 5.6 \\
\hline 14 & 300 & 533 & 0 & 36 & 0.41 & 2,400 & 260 & 5.6 \\
\hline 14 & 310 & 558 & 0 & 36 & 0.40 & 2,400 & 270 & -- \\
\hline 31 & 370 & 602 & 0 & 43 & .- & 870 & 440 & 4.9 \\
\hline 22 & 340 & 524 & 0 & 36 & -- & 710 & 380 & 5.4 \\
\hline -- & -- & 524 & 0 & .- & .- & -- & -- & -- \\
\hline -. & .- & 536 & 0 & 32 & -- & 630 & 330 & 5.0 \\
\hline 17 & 320 & 524 & 0 & 32 & -- & 600 & 370 & 5.2 \\
\hline 17 & 310 & 544 & 0 & 43 & -- & 580 & 380 & 5.7 \\
\hline 17 & 270 & 585 & 0 & 47 & -- & 620 & 370 & 5.0 \\
\hline 17 & 310 & 595 & 0 & 33 & -- & 650 & 370 & 5.0 \\
\hline 16 & 310 & 563 & 0 & 33 & -- & 680 & 400 & 5.5 \\
\hline 16 & 310 & 566 & 0 & 33 & -- & 630 & 400 & 5.5 \\
\hline 16 & 320 & 573 & 0 & 33 & -- & 640 & 400 & 5.9 \\
\hline 16 & 320 & 612 & 0 & 32 & .. & 630 & 400 & 5.3 \\
\hline 16 & 310 & 575 & 0 & 33 & -- & 670 & 420 & 5.4 \\
\hline 15 & 300 & 590 & 0 & 32 & -- & 670 & 430 & 5.5 \\
\hline 16 & 310 & 578 & 0 & 33 & -- & 740 & 440 & 5.4 \\
\hline 22 & 340 & 588 & 0 & 36 & -- & 800 & 510 & 5.4 \\
\hline 26 & 360 & 534 & 0 & 38 & -- & 860 & 510 & 4.8 \\
\hline 20 & 340 & 573 & 0 & 35 & -- & 740 & 450 & 5.1 \\
\hline 27 & 360 & 546 & 0 & 38 & -- & 820 & 480 & 5.1 \\
\hline 25 & 360 & 554 & 0 & 38 & -- & 730 & 470 & 5.7 \\
\hline 15 & 310 & 644 & 0 & 32 & -. & 610 & 390 & 5.6 \\
\hline 16 & 310 & 575 & 0 & 33 & -- & 640 & 440 & -- \\
\hline 17 & 320 & 573 & 0 & 32 & -. & 680 & 430 & 5.7 \\
\hline 30 & 370 & 544 & 0 & 41 & 0.38 & 910 & 680 & 5.4 \\
\hline 21 & 320 & 556 & 0 & 34 & 0.44 & 610 & 470 & 11 \\
\hline 17 & 320 & 578 & 0 & 33 & 0.44 & 530 & 440 & 6.4 \\
\hline 16 & 310 & 585 & 0 & 33 & 0.42 & 570 & 410 & 10 \\
\hline 15 & 300 & 540 & 0 & 43 & 0.42 & 570 & 400 & 9.2 \\
\hline 14 & 280 & 516 & 0 & 40 & 0.44 & 530 & 370 & -- \\
\hline 13 & 270 & 480 & 0 & 38 & 0.55 & 450 & 360 & .- \\
\hline 11 & 260 & -- & 0 & 40 & 0.58 & 390 & 320 & 8.0 \\
\hline 10 & 250 & 356 & 0 & 44 & 0.62 & 350 & 270 & 7.9 \\
\hline 9.2 & 230 & 336 & 0 & 44 & 0.60 & 370 & 240 & -- \\
\hline 8.7 & 220 & 334 & 0 & 47 & 0.59 & 370 & 260 & -- \\
\hline 6.4 & 160 & 310 & 0 & 48 & 0.58 & 330 & 240 & 9.3 \\
\hline 8.6 & 220 & 291 & 0 & 49 & 0.58 & 300 & 230 & 8.9 \\
\hline 8.6 & 210 & 285 & 0 & 45 & 0.56 & 380 & 240 & 8.3 \\
\hline 8.8 & 210 & 267 & 0 & 45 & 0.54 & 380 & 250 & 8.2 \\
\hline 8.7 & 220 & 295 & 0 & 45 & -- & 380 & 250 & 8.3 \\
\hline 10 & 250 & 357 & 0 & 46 & 0.55 & -- & -- & 8.3 \\
\hline 15 & 290 & 485 & 0 & 38 & 0.50 & 580 & 410 & 7.2 \\
\hline 16 & 300 & 567 & 0 & 32 & 0.45 & 650 & 480 & -- \\
\hline
\end{tabular}

